\title{
Trends in Radionuclide Concentrations in Hanford Reach Fish, 1982 through 1992
}

T. M. Poston

June 1994

Prepared for the U.S. Department of Energy under Contract DE-AC06-76RLO 1830

Pacific Northwest Laboratory

Operated for the U.S. Department of Energy by Battelle Memorial Institute 


\title{
DISCLAIMER
}

This report was prepared as an account of work sponsored by an agency of the United States Government. Neither the United States Government nor any agency thereof, nor Battelle Memorial Institute, nor any of their employees, makes any warranty, expressed or implied, or assumes any legal liability or responsibility for the accuracy, completeness, or usefulness of any information, apparatus, product, or process disclosed, or represents that its use would not infringe privately owned rights. Reference herein to any specific commercial product, process, or service by trade name, trademark, manufacturer, or otherwise does not necessarily constitute or imply its endorsement, recommendation, or favoring by the United States Government or any agency thereof, or Battelle Memorial Institute. The views and opinions of authors expressed herein do not necessarily state or reflect those of the United States Government or any agency thereof.

\author{
PACIFIC NORTHWEST LABORATORY \\ operated by \\ BATTELLE MEMORIAL INSTITUTE \\ for the \\ UNITED STATES DEPARTMENT OF ENERGY \\ under Contract DE-AC06-76RLO 1830
}

Printed in the United States of America

Available to DOE and DOE contractors from the

Office of Scientific and Technical Information, P.O. Box 62, Oak Ridge, TN 37831; prices available from (615) 576-8401. FTS 626-8401.

Available to the public from the National Technical Information Service, U.S. Department of Commerce, 5285 Port Royal Rd., Springfield, VA 22161. 


\section{DISCLAIMER}

Portions of this document may be illegible in electronic image products. Images are produced from the best available original document. 
TRENDS IN RADIONUCLIDE CONCENTRATIONS IN HANFORD REACH FISH, 1982 THROUGH 1992

T. M. Poston

June 1994

Prepared for the U.S. Department of Energy

under Contract DE-AC06-76RLO 1830

Pacific Northwest Laboratory Richland, Washington 99352

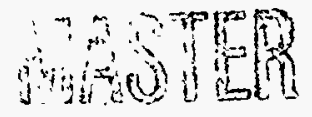


- 


\section{SUMMARY}

Environmental monitoring has been conducted at the U.S. Department of Energy's Hanford Site in southeast Washington State since 1945. Fish from the Hanford Reach of the Columbia River, which borders the Site, are monitored annually. The two objectives of this report were 1) to evaluate trends in the concentrations of radionuclides [e.g., ${ }^{90} \mathrm{Sr}$ and ${ }^{137} \mathrm{Cs}$ ] in two species of Columbia River fish [smallmouth bass and mountain whitefish] sampled from the Hanford Reach from 1982 through 1992; and 2) to determine the impact of Hanford Site releases on these two species and carp and fall chinook salmon collected during this time frame.

The evaluation found gradual reductions of ${ }^{137} \mathrm{Cs}$ in bass muscle and ${ }^{90} \mathrm{Sr}$ in bass and whitefish carcass from 1982 through 1992. Concentrations of ${ }^{90} \mathrm{Sr}$ in bass and whitefish followed the pattern established by reported Hanford Site releases from 1982 through 1992 and was supported by significnat regression analyses comparing annual releases to sample concnetration. Because data for carp have been collected only since 1990, the data base was inadequate for determining trends. Moreover, fall chinook salmon were only sampled once in this 11-year period.

The fish data were highly variable over the study period, a condition explained by the complex enviromental chemistry of the radionuclides and behavior of the fish. Concentrations of ${ }^{90} \mathrm{Sr}$ and ${ }^{137} \mathrm{Cs}$ in fish samples collected from distant background locations exceeded concentrations in Hanford Reach fish. Such an occurrence is possible because of temporal and spatial differences in atmospheric deposition of nuclear weapons testing fallout at the background locations. Fallout radionuclides may have actually increased exposure of fish to radionuclides at background locations compared to the Hanford Reach. Many other man-made gamma-emitting radionuclides were not observed at measurable concentrations, most notably ${ }^{60} \mathrm{Co}$. Estimates of the dose from consumption of Hanford Reach fish were less than 0.001 times the National Council on Radiation Protection and Measurements and the U.S. Department of Energy guideline of $100 \mathrm{mrem} / \mathrm{yr}$. 


\section{ACKNOWLEDGMENTS}

The author wishes to express his appreciation to D. D. Dauble, D. J. Bates, R. W. Woodruff, R. E. Jaquish and W. L. Templeton for critical reviews of this report, and R. E. Lundgren and A. H. McMakin for editorial assistance. Fish samples were collected by numerous Radiation Protection Technologists over the study period. E. J. Antonio, A. Krupsha, A. T. Cooper, and C. K. Russell assisted with data retrieval and data file formatting. 



\section{CONTENTS}

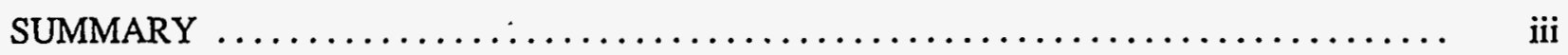

ACKNOWLEDGMENTS $\ldots \ldots \ldots \ldots \ldots \ldots \ldots \ldots \ldots \ldots \ldots \ldots \ldots \ldots \ldots \ldots \ldots \ldots \ldots$

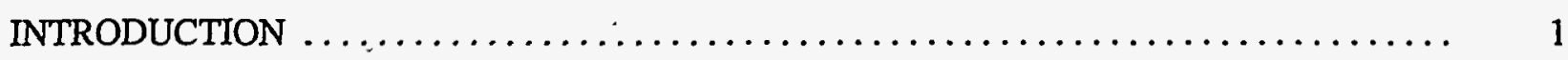

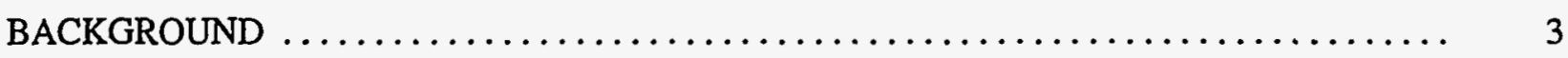

SOURCES AND HISTORICAL RELEASES $\ldots \ldots \ldots \ldots \ldots \ldots \ldots \ldots \ldots \ldots \ldots \ldots$

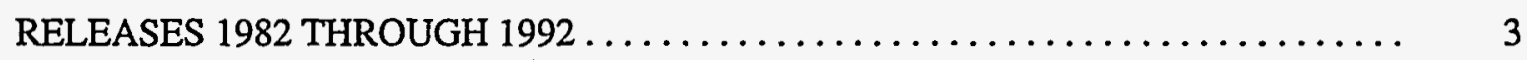

FISH SAMPLING $\ldots \ldots \ldots \ldots \ldots \ldots \ldots \ldots \ldots \ldots \ldots \ldots \ldots \ldots \ldots \ldots \ldots \ldots$

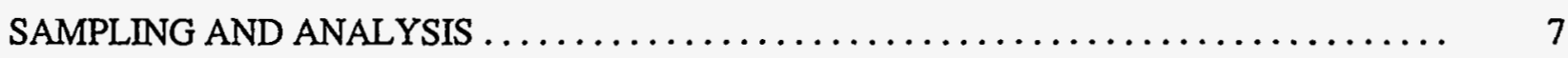

FISH COLLECTION AND SAMPLE PREPARATION $\ldots \ldots \ldots \ldots \ldots \ldots \ldots \ldots$

RADIONUCLIDE ANALYSES $\ldots \ldots \ldots \ldots \ldots \ldots \ldots \ldots \ldots \ldots \ldots \ldots \ldots \ldots \ldots \ldots \ldots \ldots \ldots \ldots$

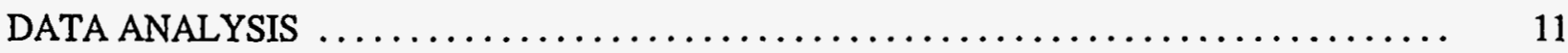

SCREENING OF DATA $\ldots \ldots \ldots \ldots \ldots \ldots \ldots \ldots \ldots \ldots \ldots \ldots \ldots \ldots \ldots \ldots \ldots \ldots \ldots \ldots \ldots$

STATISTICAL ANALYSIS $\ldots \ldots \ldots \ldots \ldots \ldots \ldots \ldots \ldots \ldots \ldots \ldots \ldots \ldots \ldots \ldots \ldots$

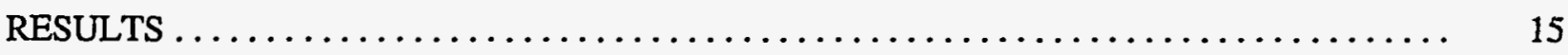

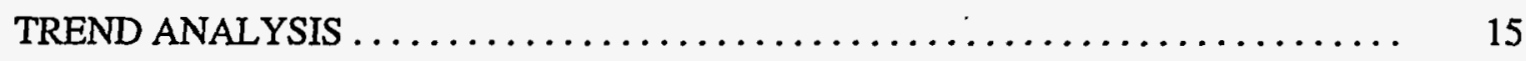

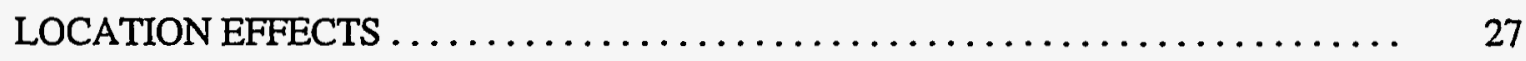

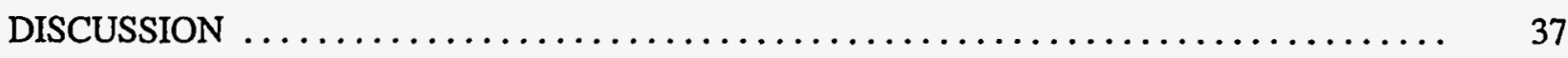

ACCUMULATION OF RADIONUCLIDES $\ldots \ldots \ldots \ldots \ldots \ldots \ldots \ldots \ldots \ldots \ldots \ldots \ldots \ldots$

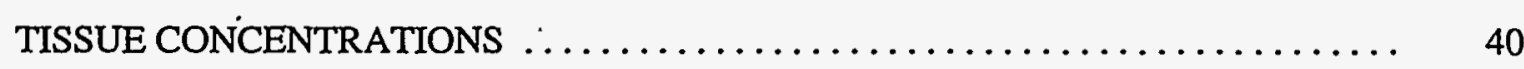

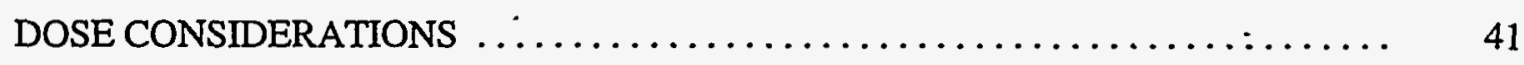

CONCLUSIONS $\ldots \ldots \ldots \ldots \ldots \ldots \ldots \ldots \ldots \ldots \ldots \ldots \ldots \ldots \ldots \ldots \ldots \ldots \ldots \ldots \ldots$

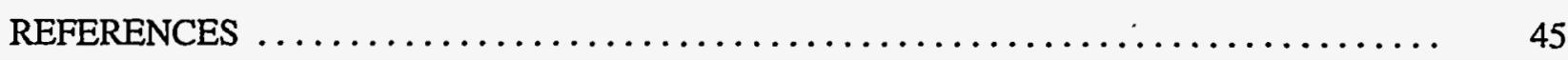

APPENDIX A - RADIONUCLIDE CONCENTRATIONS IN FISH $\ldots \ldots \ldots \ldots \ldots \ldots \ldots \ldots$ A.1

APPENDIX B - ANOVA TABLES FOR TRENDS AND LOCATION EFFECTS $\ldots \ldots \ldots \ldots$ B. 1 


\section{FIGURES}

1 Estimated Annual Releases to the Columbia River from the 100 Areas .......... 5

2 Sampling Locations for Hanford Reach and Background Fish $\ldots \ldots \ldots \ldots \ldots \ldots \ldots$

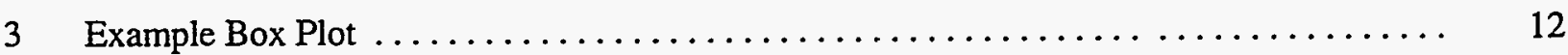

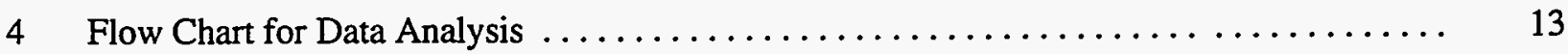

5 Box Plot of ${ }^{90} \mathrm{Sr}$ in Bass Muscle Collected from F Slough and Sunnyside .......... 18

6 Box Plot of ${ }^{137} \mathrm{Cs}$ in Bass Muscle Collected from F Slough and Sunnyside . . . . . . . . 19

7 Model I and Second-Order Regression of Log-Transformed Median Concentrations of

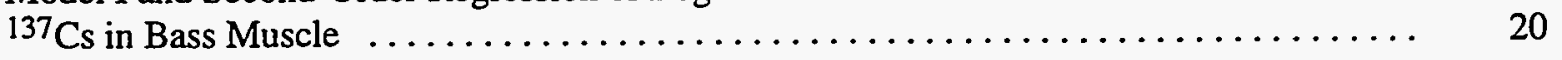

8 Box Plot of ${ }^{90} \mathrm{Sr}$ in Bass Carcasses Collected from F Slough and Sunnyside ......... 21

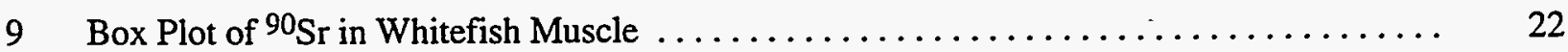

10 Model I and Second-Order Regression of Log-Transformed Median Concentrations of

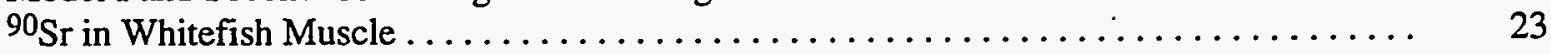

11 Model II Regression of Log-Transformed Median Concentrations of ${ }^{90} \mathrm{Sr}$ in Whitefish

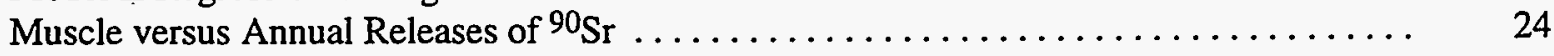

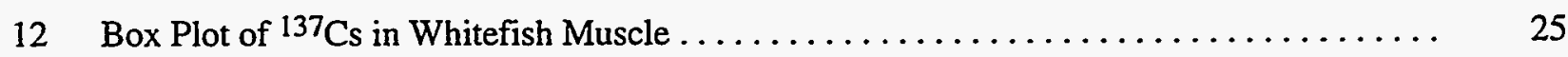

13 Box Plot of ${ }^{90} \mathrm{Sr}$ in Whitefish Carcass. . . . . . . . . . . . . . . 26

14 Model I and Second-Order Regression of Log-Transformed Median Concentrations of

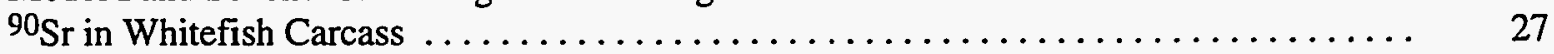

15 Model II Regression of Log-Transformed Median Concentrations of ${ }^{90} \mathrm{Sr}$ in Whitefish

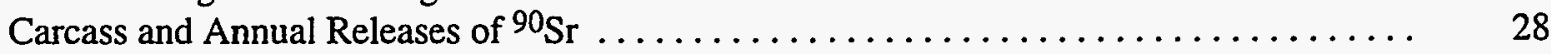

16 Box Plot of ${ }^{90} \mathrm{Sr}$ in Bass Carcasses Collected from F Slough and Sunnyside . . . . . . . 29

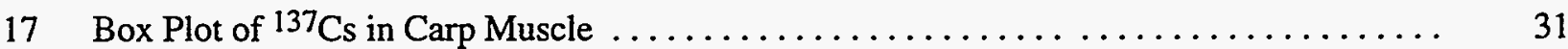

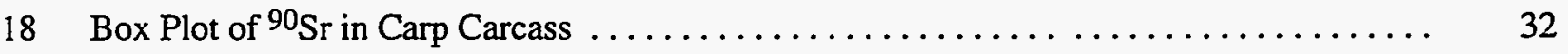




\section{TABLES}

1 Species, Location, and Number of Fish Sampled from 1982 Through $1992 \ldots \ldots \ldots \ldots \ldots$

2 Screening Evaluation of Ratio of Total Analytical Error/Concentration for Fish Results .......................................

3 Yearly Comparison of Statistically Significant Differences by Fisher's PLSD Comparisons of Log-Transformed Means of ${ }^{90} \mathrm{Sr}$ in Bass Carcass Collected from F Slough.

4 Scheffé's Comparisons of Log-Transformed Means of ${ }^{137} \mathrm{Cs}$ in Carp Muscle by Location, 1990 Through 1992

5 Scheffé's Comparisons of Log-Transformed Means of ${ }^{90} \mathrm{Sr}$ in Carp Carcass by Location, 1990 Through 1992

6 Scheffé's Comparisons of Log-Transformed Means of ${ }^{90} \mathrm{Sr}$ in Whitefish Muscle by Location, 1988 Through 1992

7 Scheffés Comparisons of Log-Transformed Means of ${ }^{90} \mathrm{Sr}$ in Whitefish Carcass by Location, 1988 Through 1992 


\section{INTRODUCTION}

The U.S. Department of Energy's (DOE) Hanford Site was established in 1943 in southeastern Washington State for nuclear materials production. Historically, operations at the Site have resulted in the release of radioactivity to the air, ground, and Columbia River. Releases to the ground have resulted in radionuclides like tritium $\left({ }^{3} \mathrm{H}\right),{ }^{90} \mathrm{Sr},{ }^{99} \mathrm{Tc}$, and ${ }^{129} \mathrm{I}$, which can migrate with ground water, to be discharged to the Columbia River in seeps and springs (Dirkes 1990; McCormack and Carlile 1984). The discharge of radioactivity to the Columbia River results in the exposure of fish to radioactivity and potential accumulation of radioactivity in fish. Accumulation of radioactivity by fish from reactor effluents was an early concern of Hanford scientists and led to efforts (since 1945) by Site environmental scientists to monitor levels of radioactivity in fish (Denham et al. 1993) that continues today.

Environmental monitoring documents levels of radioactivity in many types of environmental media. Historically, environmental monitoring has included agricultural products, soil, vegetation, air, surface and ground water, wildlife, aquatic organisms, and fish, with the objective of identifying contaminant contributions from the Hanford Site. Monitoring information has been published in monthly, quarterly, and, since 1957, annual reports to summarize the environmental status of the Hanford Site. The most recent edition was published in July 1993 for the 1992 calendar year (Woodruff et al. 1993).

The recent emphasis and shift from nuclear materials production to environmental restoration at the Hanford Site have focused additional attention on environmental radioactivity around the Site. The data are used primarily to estimate the dose to the surrounding public and quantify Hanford Site impacts, e.g., monitoring data have been used extensively for dose estimates from the Hanford Site by the Hanford Environmental Reconstruction Project (HEDR) (Denham et al. 1993; Heeb and Bates 1994; Walters et al. 1992). Data are also used to assess concentrations and trends of radioactive contamination in environmental media, like fish, from the Hanford Reach of the Columbia River.

The objective of this report is to evaluate radionuclide concentrations in Columbia River fish [smallmouth bass (Micropterus dolomieui), carp (Cyprinus carpio), mountain whitefish (Prosopium williamsoni), and chinook salmon (Oncorhynchus tshawytscha)] collected from the Hanford Reach for the years 1982 through 1992. This evaluation addresses two basic issues. What were the trends of radionuclide concentrations in fish in the Hanford Reach, and how do they relate to reported releases of radionuclides to the river? The report specifically addresses ${ }^{90} \mathrm{Sr}$ and ${ }^{137} \mathrm{Cs}$, as these radionuclides are the only two man-made radionuclides still found in Hanford Reach fish. The data collected during these years were examined for trends over time and relationships to releases of liquid effluents associated with Hanford operations.

The second issue is were concentrations of radionuclides in Hanford Reach fish different compared to background fish collected from areas designated as background locations? The same species of fish found in the Hanford Reach have recently been collected from locations distant, generally upwind, and upstream of the Hanford Site as representative of background concentrations of radioactivity. Results for these background samples are compared with those for samples collected along the Hanford Reach since 1988 or 1990 to measure whether Hanford operations are currently having any effect on radionuclide concentrations in fish. Evaluation of location effects is confounded by the presence of ${ }^{90} \mathrm{Sr}$ and ${ }^{137} \mathrm{Cs}$ fallout from historical weapons testing, which was. performed on a global scale in the $1950 \mathrm{~s}$ and early 1960 s. 


\section{BACKGROUND}

An understanding of the current state of radiological impacts on Hanford Reach fish can be attained by knowledge of past practices and discharges at the Hanford Site. This section provides a brief overview of past practices and how they have influenced exposure of Hanford Reach fish to Site effluents. More comprehensive discussions of past practices can be found in Denham et al. (1993); Heeb and Bates (1994); and Walters et al. (1992). This background discussion consists of three sections: sources and historical releases, releases from 1982 to 1992, and special fish sampling.

\section{SOURCES AND HISTORICAL RELEASES}

The largest radioactive releases from Hanford to the Columbia River occurred between 1944 and 1971 when as many as eight single-pass plutonium production reactors were operating. Single-pass reactor designs allow the cooling water to be exposed to a flux of neutrons as it passes through the reactor core. During passage, elements in the water or found on the reactor cooling pipes (scale, corrosion products) may absorb a neutron and transform into a radioactive isotope of the element. This process, called neutron activation, produced the majority of radioactivity discharged to the Columbia River because the cooling water was returned to the Columbia River either directly in the early years of the Site, or, in latter years, after a short detention time in retention basins. Most of the radionuclides produced in this manner had very short half-lives and decayed quickly to stable isotopes, hence the subsequent mitigative addition of retention basins to the effluent discharge systems.

The amount of released radioactivity varied over the years based on the number of reactors online, power level. of the reactors, basin retention time, seasonal changes in the concentrations of elements in the Columbia River, chemicals used to pretreat cooling water, corrosion rates of reactor piping and fuel element cladding, the frequency of fuel element failures, and water flow of the Columbia River (Walters et al. 1992). Highest.releases occurred from 1957 through 1965 when all eight single-pass plutonium production reactors were operating. Estimated releases for the period of 1944 to 1971 are about 41.6 million curies (Heeb and Bates 1994). Much of this released activity consisted of radionuclides with very short half-lives. Phosphorus-32 $\left(\mathrm{T}_{1 / 2}=14\right.$ days $)$ and ${ }^{65} \mathrm{Zn}\left(\mathrm{T}_{1 / 2}=245\right.$ days $)$ were the radionuclides most prone to accumulate in fish flesh during this time. Since the retirement of the last single-pass reactor in 1971 , the amount and distribution of discharged radionuclides have changed from predominantly activation products to fission products (Cushing et al. 1980).

N Reactor, which had a closed cooling system, started operation in 1963 and was officially retired in 1989. Radioactivity associated with $\mathrm{N}$ Reactor entered the river from contaminated seepage springs rather than direct discharge of single-pass cooling water.

\section{RELEASES 1982 THROUGH 1992}

In 1982, 373 curies (Ci) of activity were discharged to the Columbia River (Sula et al. 1983). The primary constituent was tritium $\left({ }^{3} \mathrm{H} ; 360 \mathrm{Ci}\right)$; and ${ }^{60} \mathrm{Co},{ }^{90} \mathrm{Sr}$, and ${ }^{137} \mathrm{Cs}$ represented a release of less than $4 \mathrm{Ci}$ combined. Currently, the largest quantities of radioactivity released at Hanford to the Columbia River are found in contaminated ground water associated with the 100 Areas along the Benton County shoreline of the Hanford Reach (Dirkes 1990; McCormack and Carlile 1984). Less than 1.2 Ci were released to the Columbia River in 1992. The releases consisted of about $86 \%$ tritium (as tritiated water), 
$14 \%{ }^{90} \mathrm{Sr}$, and a very small percentage of ${ }^{60} \mathrm{Co},{ }^{137} \mathrm{Cs}$, and other radionuclides in the sub-mCi range (Woodruff et al. 1993).

Tritium in water equilibrates rapidly with fish tissue (NCRP 1979); therefore, ${ }^{3} \mathrm{H}$ has not been monitored in fish tissue, and the concentrations in wet fish tissue would be approximately $90 \%$ of the levels reported in Columbia River water, assuming that tissue is $90 \%$ water.

Cobalt-60 generally accumulates in kidney, spleen, and liver and does not accumulate in bone or muscle of fish (Poston and Klopfer 1988). The only documented recent discharge of ${ }^{60} \mathrm{Co}$ to the Columbia River is the $100-\mathrm{N}$ springs, and there the relative concentration compared to ${ }^{90} \mathrm{Sr}$ was small. Considering the dilution afforded by the Columbia River and ${ }^{60} \mathrm{Co}$ 's relatively short half-life of 5.2 years, only low concentrations of ${ }^{60} \mathrm{Co}$ were infrequently found in fish muscle or carcass over the current study period.

Reported releases of ${ }^{90} \mathrm{Sr}$ and ${ }^{137} \mathrm{Cs}$ from 1982 through 1992 indicate maximum releases primarily from ground-water seeps in 1984 through 1986 compared to the preceding and following years (Figure 1). Monitored concentrations in water of ${ }^{90} \mathrm{Sr}$ upstream and downstream from the Hanford Site indicate only a slight potential for a Hanford impact (Dirkes 1994). In many of the years, there was no measured difference between samples from upstream and downstream locations. It was difficult to measure this difference because of elevated background concentrations in the Columbia River upstream of Hanford from historical radioactive fallout deposited in the Columbia River watershed as a result of atmospheric weapons testing.

\section{FISH SAMPLING}

Since 1945, fish have been a primary focus of Hanford Site monitoring efforts because of the direct discharges of liquid effluent to the Columbia River. In the mid-1950s, sampling efforts shifted from whole-body analysis of feral and sport fish to filets (muscle) of sport fish. A major effort was expended in the $1960 \mathrm{~s}$ both to quantify levels of radioactivity in fish and to characterize the recreational sport fish harvest and consumption from the Hanford Reach and Lake Walulla (McNary Dam impoundment) immediately downstream of the Site (Soldat 1970). During the 1982-through-1992 time frame, special sampling was performed for salmon and sturgeon in addition to the routine sampling of bass, whitefish, and carp.

Salmonids represent a group of fish of great interest among sport fishers; however, historical data on concentrations of radioactivity in adult salmon or steelhead indicate little propensity to accumulate radionuclides from the Columbia River (Foster et al. 1965, 1966, 1967). These observations were also borne out in samples of salmon intermittently collected in the 1960s and 1970s (Eberhardt et al. 1989; Watson et al. 1970). Salmon were sampled in 1988 at White Bluffs (between the 100-D and 100-F Areas) and Priest Rapids, and are discussed in that annual report (Jaquish and Bryce 1989).

Concentrations of the radionuclide burden of white sturgeon (Acipenser transmontanus) have decreased significantly since the $1960 \mathrm{~s}$. There were no significant differences in concentrations of ${ }^{90} \mathrm{Sr}$ or ${ }^{137} \mathrm{Cs}$ in sturgeon cartilage or muscle collected from the Hanford Reach and locations upstream and downstream of the Site (Dauble et al. 1993). Trends from 1972 through 1988 in other species of wildlife and fish monitored at the Hanford Site have been reported (Eberhardt et al. 1989). Generally, data from the early 1970 s show measurable concentrations of ${ }^{60} \mathrm{Co}$ and ${ }^{65} \mathrm{Zn}$ that decreased to less-than-detection 


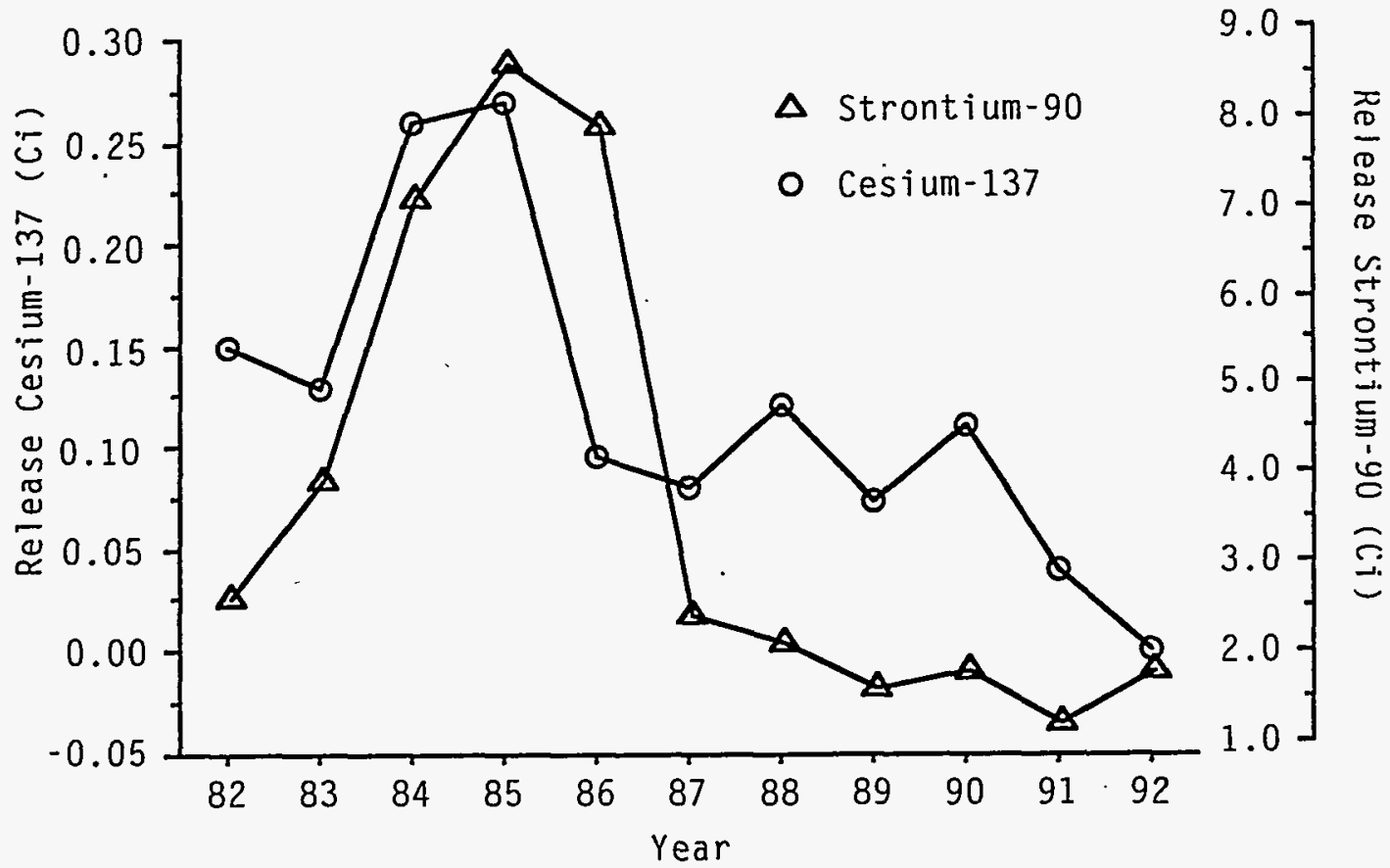

FIGURE 1. Estimated Annual Releases (Curies) to the Columbia River from the 100 Areas (Source: Hanford Site monitoring reports)

limits through the 1970s into the early 1980s. For example, from 1982 through 1992, 134 whitefish muscle samples were collected and analyzed for ${ }^{60} \mathrm{Co}$. During this time, only one sample collected between the 100-N and 100-D Areas had a measurable concentration of $0.05( \pm 50 \%) \mathrm{pCi} / \mathrm{g}$ wet. Twentyseven samples (about $20 \%$ of all samples) had concentrations of ${ }^{60} \mathrm{Co}$ in which the total analytical error ranged from $50 \%$ to $100 \%$ of the concentration. Collectively, concentrations of ${ }^{60} \mathrm{Co}$ were generally not measurable in whitefish filets, and no conclusions can be drawn regarding trends in the concentration of ${ }^{60} \mathrm{Co}$ in whitefish muscle. Decreases in the amounts of radionucides in fish were attributed to reduced discharges of radioactive effluents and radioactive decay (Eberhardt et al. 1989).

Fish have been monitored quite extensively over the past 40 years as the basis for estimating the potential radiation dose to consumers of Columbia River fish. Estimated dose rates from the consumption of sport fish in the mid-1960s ranged from 80 to $100 \mathrm{mrem}$ (Foster et al. 1965, 1966, 1967) and are considerably higher ( $>100$ times) than present dose estimates because of the presence of ${ }^{32} \mathrm{P}$ and $65 \mathrm{Zn}$ in fish flesh in the 1960s. Additionally, the monitoring data document exposure of fish to contamination in the Columbia River. The evaluation of fish data over periods of time provides valuable insight into trends and contributes further to our understanding of the environmental behavior and potential impact of radionuclides in the Columbia River. 



\section{SAMPLING AND ANALYSIS}

The methods used to collect and prepare fish samples and conduct radiochemical analysis are discussed below.

\section{FISH COLLECTION AND SAMPLE PREPARATION}

This report evaluates radionuclide levels in four species of fish collected from the Hanford Reach from 1982 through 1992 (Figure 2). The species were smallmouth bass, carp, mountain whitefish, and fall chinook salmon. Fish collection procedures are documented in Surface Environmental Surveillance Project records and are based on standard methods (Nielsen and Johnson 1983); collection methods were rod and reel, gill netting, and electroshocking. The primary sample was a filet that was removed by methods routinely used by fishers (i.e., the muscle was removed from the backbone and skinned). While considered a muscle sample, filets may contain small bones that extend laterally from the spinal column into the musculature. Kettle River whitefish filets were combined into one sample from two fish because of their small size. Fish muscle is the target tissue of ${ }^{137} \mathrm{Cs}$ accumulation.

The remainder of the fish was eviscerated and submitted as a carcass sample. In large specimens, the head was removed. Carcass samples are predominately bone, the target tissue for ${ }^{90} \mathrm{Sr}$ accumulation.

Bass were collected from F Slough [100-F Area, river mile (RM) 367] for several reasons:

- F Slough is located downstream of $100-\mathrm{N}$ Area springs, which contain ${ }^{90} \mathrm{Sr}$ (Figure 2).

- F Slough is one of three sloughs that support spawning bass from RM 358 to 367.

- Slack water in the slough allows accumulation of sediment that may affect exposure of fish to sediment-bound radionuclides.

- Bass are a popular sport fish subject to harvest that congregate in the slough in the spring to breed, thus facilitating sample collection.

In 1982, a small number of bass were collected from the Hanford Townsite shoreline (5) at RM 360 to 363 and from Priest Rapids (1) at RM 390 to 395 . These bass samples were not included in the analysis because their collection ceased after the first year of the study period. Bass were sampled at $F$ Slough annually from 1983 to 1990 , when the scheduling was modified to a biannual cycle with collections on even-numbered years (Table 1). Background samples of bass were collected from a pond near Sunnyside, Washington, in 1991.

Routine carp sampling was initiated in 1990 with sampling at the $100-\mathrm{N}$ Area and Vantage Washington (background location), and expanded to the 300 Area in 1991. Carp were selected for analysis because they are a food fish for specific ethnic groups. Also, carp are omnivorous bottom feeders. Bottom-feeding species are likely to accumulate radioactivity to greater levels than higher trophic-level species (Poston and Klopfer 1988). The 300 Area (RM 340 to 344) and 100-N Area 


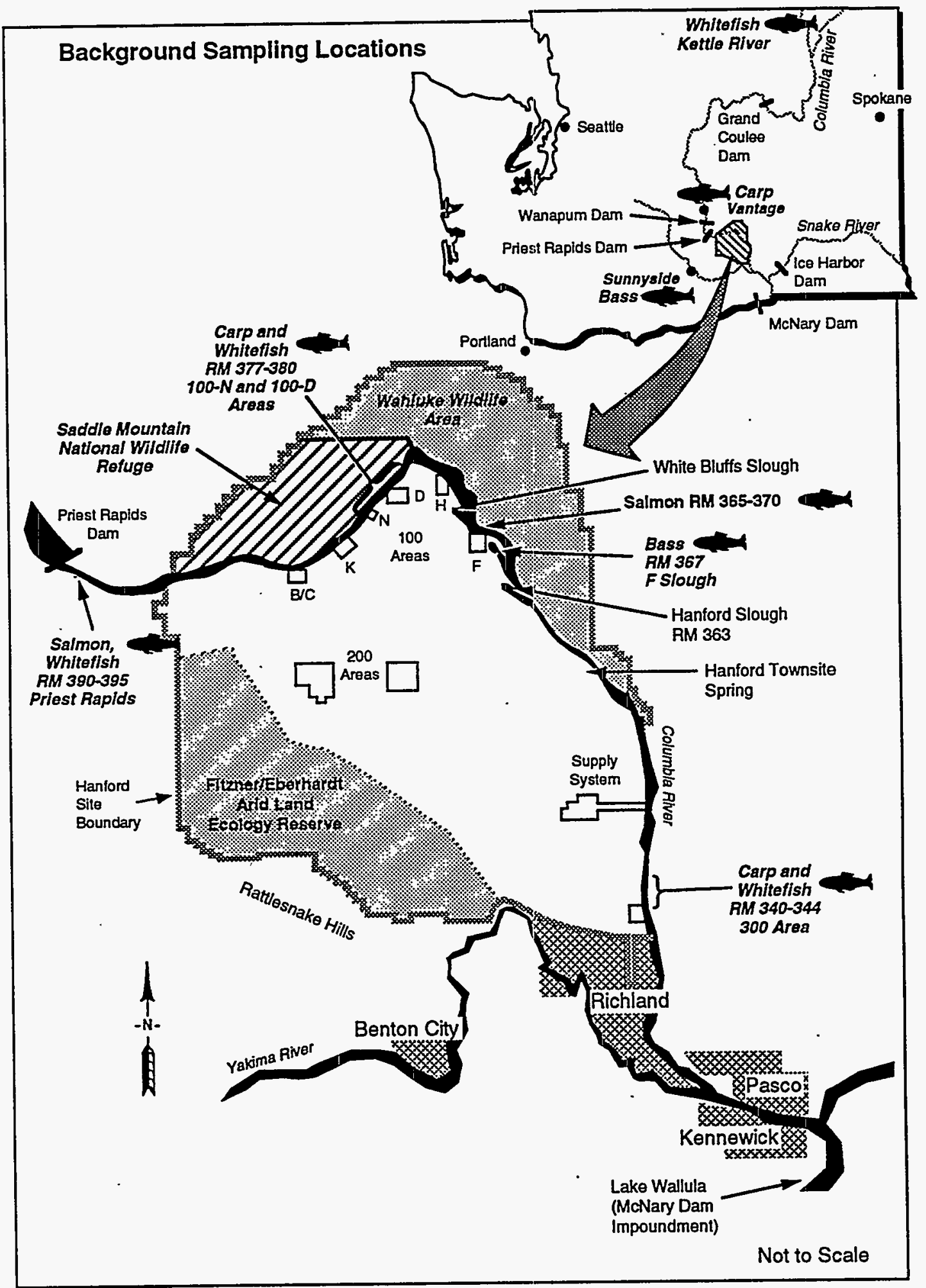

S9401078.2A

FIGURE 2. Sampling Locations for Hanford Reach and Background Fish 
TABLE 1. Species, Locations, and Number of Fish Sampled from 1982 Through 1992

\begin{tabular}{|c|c|c|c|c|c|c|c|c|c|c|c|c|}
\hline \multirow[b]{2}{*}{ Species } & \multirow[b]{2}{*}{ Location } & \multicolumn{11}{|c|}{ Year } \\
\hline & & $\underline{82}$ & $\underline{83}$ & $\underline{84}$ & $\underline{85}$ & $\underline{86}$ & $\underline{87}$ & $\underline{88}$ & $\underline{89}$ & $\underline{90}$ & 21 & 22 \\
\hline Bass & F Slough & -(a) & 5 & 5 & 5 & 5 & 5 & 5 & 5 & 5 & - & 5 \\
\hline Bass & Sunnyside & - & - & - & - & - & - & - & - & - & 20 & - \\
\hline Bass & Hanford $\operatorname{TS}^{(b, c)}$ & 5 & - & - & - & - & - & - & - & $=$ & - & - \\
\hline Bass & Priest Rapids (c) & 1 & - & - & - & - & - & - & - & - & - & - \\
\hline Carp & $100-\mathrm{N}$ Area & - & - & - & - & - & - & - & - & 6 & 4 & 1 \\
\hline Carp & 300 Area & - & - & - & - & - & - & - & - & - & 5 & 5 \\
\hline Carp & Vantage & - & - & - & - & - & - & - & - & 3 & 10 & - \\
\hline Whitefish & Priest Rapids & 9 & 5 & 5 & 5 & 5 & 5 & 5 & 5 & 5 & - & - \\
\hline Whitefish & 100-D Area & 9 & 14 & 10 & 10 & 10 & 10 & 10 & 6 & 10 & 5 & - \\
\hline Whitefish & 100-N Area & - & - & - & - & - & - & - & - & 5 & 1 & 10 \\
\hline Whitefish & 300 Area & - & - & - & - & - & - & - & - & 5 & 2 & 10 \\
\hline Whitefish & Kettle River & - & - & - & - & - & - & - & - & - & 9 & - \\
\hline Whitefish & Hanford TS(c) & 5 & 7 & - & - & - & - & - & - & - & - & - \\
\hline Whitefish & Ringold(b,c) & 7 & 5 & - & - & - & - & - & $\therefore$ & - & - & - \\
\hline Salmon & 100-D Area & - & - & - & - & - & - & 5 & - & - & - & - \\
\hline Salmon & Priest Rapids & - & - & - & - & - & - & 5 & - & - & - & - \\
\hline
\end{tabular}

(a) Dash indicates no samples were collected.

(b) Hanford Townsite at RM 360 to 363, Ringold at RM 350 to 354.

(c) Samples not used in analysis.

(RM 380) were sampled because of concern of seeps releasing contaminants into the river. Tritium, ${ }^{60} \mathrm{Co}$, and ${ }^{90} \mathrm{Sr}$ are the primary radionuclides of interest in the $100-\mathrm{N}$ Area springs. The 300 Area springs contain elevated levels of ${ }^{3} \mathrm{H}$ and uranium isotopes. Additionally, because ${ }^{99} \mathrm{Tc}$ was present in Hanford Townsite springs (Woodruff et al. 1993), ${ }^{99} \mathrm{Tc}$ was also analyzed in 300 Area carp muscle.

Fall chinook salmon were collected once in 1988 because of interest raised at that time.

Whitefish were collected every year of the study period (see Table 1). Whitefish were sampled because they are a bottom-feeding sport fish that historically has accumulated some of the highest levels of radioactivity in the Hanford Reach. Whitefish results from the 100-D Area (RM 377) were combined with results from the 100-N Area for evaluation because the 100-D and 100-N Areas are both influenced by the 100-N Area springs. From 1982 through 1990, whitefish were collected from the Vernita Bridge upstream to Priest Rapids Dam. There is no certainty that these fish have always resided in this area and that they had not resided in other sections of the Hanford Reach. However, this is the location most likely to be fished for whitefish immediately upstream from the Hanford Site. In 1982 and 1983, whitefish were collected from Ringold (RM 350 to 354) and the Hanford Townsite. These whitefish samples were not included in this analysis because their collection ceased after the first 2 years of the study period.

Background samples of whitefish were collected from the Kettle River in northeastern Washington in 1991.

Trends of radioactivity in fish were evaluated in bass collected from F Slough and whitefish collected from Priest Rapids and the 100-N to 100-D Areas from 1982 through 1992 (see Table 1). Location effects were evaluated for bass and carp using data collected from 1990 through 1992 and for whitefish from 1988 through 1992. 


\section{RADIONUCLIDE ANALYSES}

Fish filet samples are analyzed by gamma spectroscopy for a large number of gamma-emitting radionuclides (Woodruff et al. 1993). Routinely, only ${ }^{7} \mathrm{Be},{ }^{40} \mathrm{~K}$, and ${ }^{137} \mathrm{Cs}$ were detected in fish. Cobalt60 was infrequently detected in the early 1980 s, but decay and very small releases to the environment have reduced ${ }^{60} \mathrm{Co}$ to undetectable levels in fish samples. Radiochemical methods are also used to measure ${ }^{90} \mathrm{Sr}$ in carcass and muscle samples. In 1991 and 1992, some samples of carp and whitefish from the 300 Area were analyzed for ${ }^{99} \mathrm{Tc}$ or uranium isotopes. Technetium- 99 and uranium results are listed in Appendix A; however, it was not possible to address trends as the time frame covers only the most recent 2 years.

All results were reported as $\mathrm{pCi} / \mathrm{g}$ wet weight. Minimum detectable concentrations (MDC on a wet-weight basis) for ${ }^{60} \mathrm{Co},{ }^{90} \mathrm{Sr}$, and ${ }^{137} \mathrm{Cs}$ were $0.01,0.005$, and $0.015 \mathrm{pCi} / \mathrm{g}$, respectively. The ${ }^{137} \mathrm{Cs}$ MDC was adjusted to $0.02 \mathrm{pCi} / \mathrm{g}$ for fish samples analyzed in 1991 and 1992 . The MDCs for other gamma-emitting radionuclides ranged from 0.02 to $0.2 \mathrm{pCi} / \mathrm{g}$. Technetium- 99 has an $\mathrm{MDC}$ of $1.0 \mathrm{pCi} / \mathrm{g}$, and uranium isotopes have an MDC of $0.02 \mathrm{pCi} / \mathrm{g}$. These MDCs are a contractual guideline that the analytical facilities are obligated to meet by adjusting sample count time and aliquot size.

Analyses whose results are reported herein were performed by two laboratories. Fish samples collected before 1990 were analyzed by U.S. Testing, Inc. (UST), Richland, Washington. Samples collected in 1990 and after were analyzed by IT Analytical Services, Richland, Washington, which acquired the UST facilities in 1991. The methods used for radiochemical analyses are summarized by Jaquish and Bryce (1990). 


\section{DATA ANALYSIS}

The data for each species and radionuclide combination were screened to determine whether an adequate number of measurements were present for a statistical evaluation. The data were electronically retrieved from PNL's Surface Environmental Surveillance Project (SESP) data base and transferred to Excel (Microsoft Corp.) and StatView (Abacus Concepts, Inc.) software for data analysis.

\section{SCREENING OF DATA}

To determine the suitability of the data for analysis, each analytical result for ${ }^{60} \mathrm{Co},{ }^{90} \mathrm{Sr}$, and ${ }^{137} \mathrm{Cs}$ was evaluated by calculating the ratio of the two sigma analytical error (combined counting error and radiochemical analytical error) to the concentration. Four categories of the resulting ratio were determined: 1) values less than 0 indicated a negative analytical result; 2) values between 0 and 0.50 indicated a result with an associated two sigma analytical error of $\pm 50 \%$ or less, hereafter referred to as "definitive results;" 3) values between 0.50 and 1.00 indicated a result with an error between $50 \%$ and $100 \%$ of the result; and 4) values greater than 1.0 indicated an estimate of the two sigma analytical error in excess of $100 \%$ of the concentration. Generally, only data types with a preponderance of values ( $>40 \%$ of all values for a given analyte and tissue) in Categories 2 and 3 were considered for further statistical analysis using all the reported values. Collectively, Categories 2 and 3 concentrations are referred to as "measured" values in the text. Some analyses in 1982 and 1983 had only the two sigma counting error reported, in which case that was used to calculate the ratio.

\section{STATISTICAL ANALYSIS}

Data were graphically presented in box plots that show the $10^{\text {th }}, 25^{\text {th }}$, median $\left(50^{\text {th }}\right.$ percentile), $75^{\text {th }}$, and $90^{\text {th }}$ percentiles for each year and location as well as individual concentrations that lie above or below the $90 \%$ or $10 \%$ levels, respectively (Figure 3 ). Median concentrations were reported because they are not as radically influenced by outliers and may provide a more accurate estimate of the central tendency of environmental data compared to mean concentrations when sample sizes are small.

Parametric statistical analyses were used to evaluate trends, location effects, and the relationship between bass and whitefish concentrations of radionuclides to reported annual releases to the Columbia River from 1982 through 1992 (Figure 4).

Generally, radionuclide concentrations are log-normally distributed in environmental media (Eberhardt and Gilbert 1980), i.e., the data are generally skewed, but a log-transformation will produce a more normal bell-shaped distribution. Distributions of log-transformed and non-transformed data for each combination of fish, tissue, and location were compared to determine whether log-transformation was appropriate. In nearly all cases, log-transformation produced a more normal distribution of data than the non-transformed data. Negative values are lost when a log-transformation is applied to the data, hence biases can be introduced into the evaluation. Where analysis of variance (ANOVA) was used to determine location effects or differences in concentrations among years, the statistical result (i.e., significance) was unaffected by log-transformation except for values for ${ }^{137} \mathrm{Cs}$ in muscle, for which there was a larger proportion of negative values in certain species and locations. All ANOVA tables are located in Appendix B. 


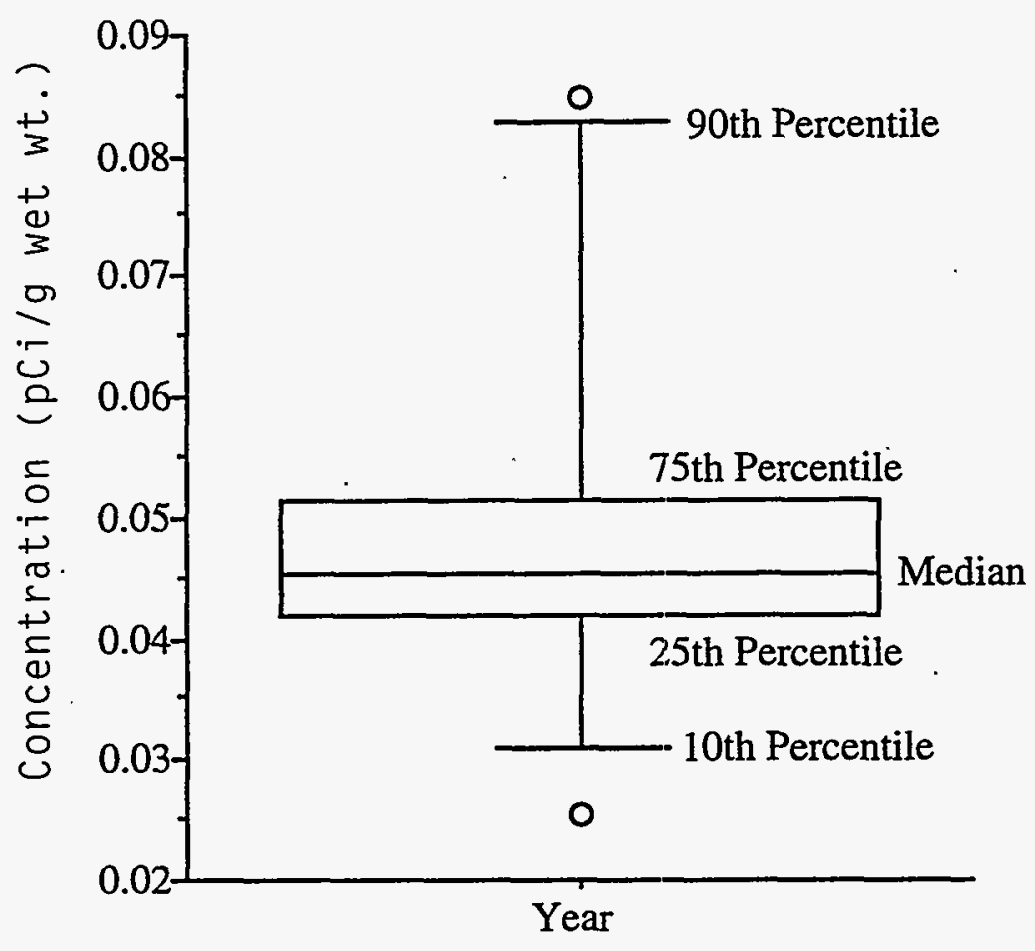

FIGURE 3. Example Box Plot (circles indicate results either above or below the $90^{\text {th }}$ and $10^{\text {th }}$ percentiles, respectively)

\section{Trend Effects}

Trends were initially evaluated by conducting a Model I (simple) regression of log-transformed median values by year for bass and whitefish at each location where 9 or more years of data were available (Sokal and Rohlf 1981). Both a Model I and a second-order polynomial regression by year were performed. The second-order polynomial was used because the reported releases of ${ }^{90} \mathrm{Sr}$ and ${ }^{137} \mathrm{Cs}$ indicated a parabolic shape (see Figure 1), which is expressed better by a two-term regression model than a single linear model. Additionally, the log-transformed median was regressed against reported releases to the river (see Figure 1) to determine whether there was a significant Model II regression. Analysis of bass and whitefish followed this general pattern. Carp and salmon data were not used to evaluate trends because they were only collected for 3 and 1 years, respectively. The ANOVA tables for regression analysis are located in Appendix B.

\section{Location Effects}

The statistical analyses for location effects involved ANOVA initially by location, then by year within location if the analysis was significant, as indicated by a $\mathrm{P}$ value of $<0.05$. Evaluation of location effects was limited to 3 years for bass and carp (1990 through 1992), and 5 years for whitefish (1988 through 1992). Comparisons among years were performed to identify years that were significantly different than other years for a particular location over the 11-year study period and to support in part the regression analysis conducted for trends. 


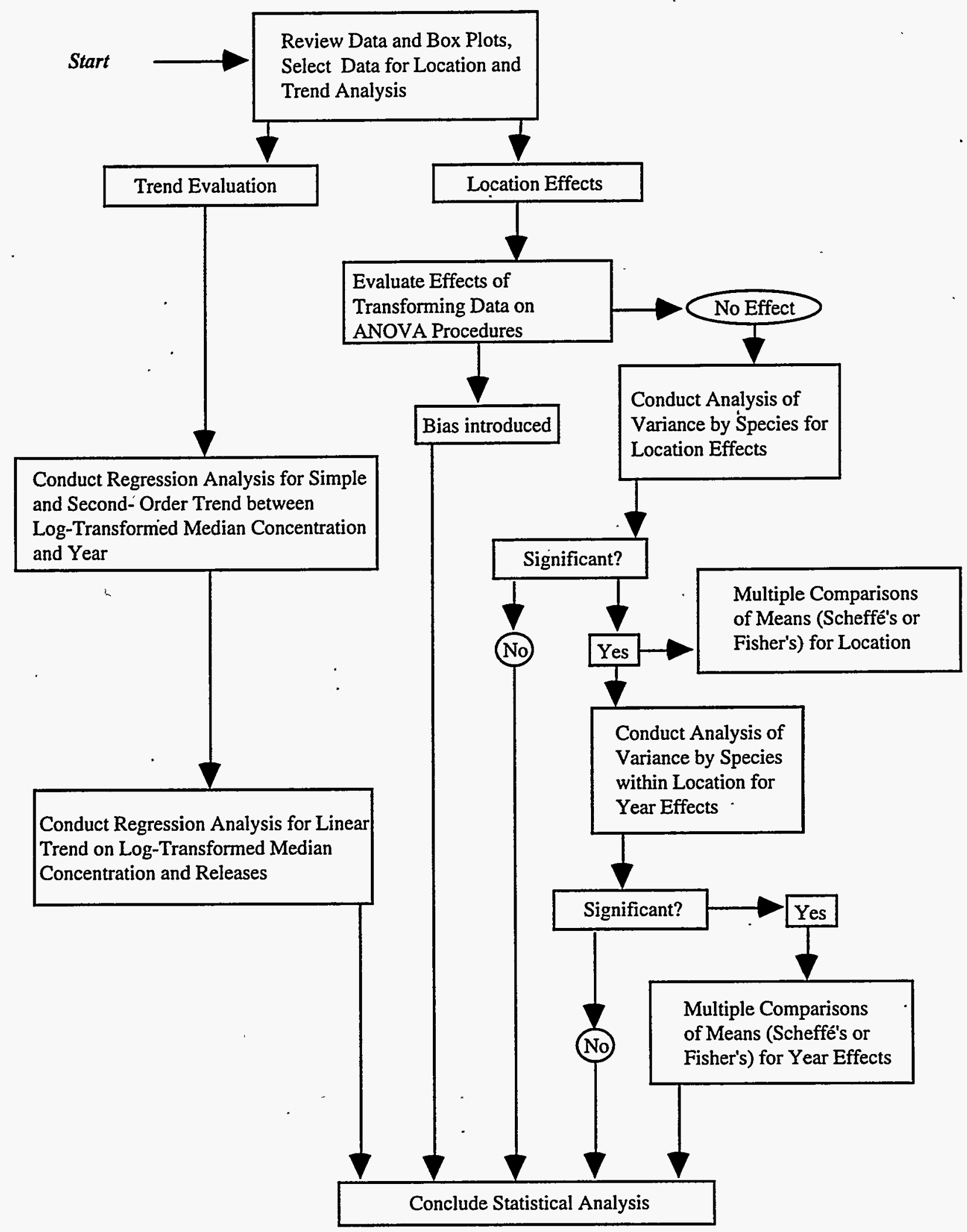

EIGURE 4. Flow Chart for Data Analysis 
The ANOVA was followed by a multiple comparison of means when significant for either location effects or year effects. Either Fisher's Protected Least Significant Differences (PLSD) test or Scheffé's correction for multiple comparisons of means was used, depending on whether the comparison was judged as a planned comparison or a post-hoc comparison. Planned comparisons involved data sets in which the collections at a particular location were planned, documented, and generally completed as planned. Fisher's PLSD test was used on comparisons among years for bass collected at F Slough and whitefish collected at Priest Rapids and the 100-N to 100-D Areas. Generally, Scheffés correction was used because of the addition of several new study areas over a short period of time or when the numbers of fish collected were radically different from what had been planned. Fisher's test is less conservative than Scheffé's; i.e., it is more likely to show a difference between treatments. 


\section{$\underline{\text { RESULTS }}$}

This section discusses the qualitative and quantitative evaluation of radionuclide concentrations in fish. The evaluation consisted of two efforts. The initial task assessed trends from 1982 through 1992 in bass and whitefish. The second task focused on differences among sampling locations in the Hanford Reach and background locations from 1988 through 1992. This analysis also evaluated differences between sample concentrations by year. The screening analysis of fish tissue data identified numerous data sets of ${ }^{90} \mathrm{Sr}$ and ${ }^{137} \mathrm{Cs}$ among bass, carp, and whitefish that were statistically analyzed (Table 2 ).

Strontium-90 was present in nearly all carcass samples collected from the Hanford Reach and each species' respective background locations. Because there were very few negative values, there were no computational problems with statistical analysis of log-transformed data in carcass, or muscle samples.

Cesium-137 was quantitatively analyzed in F Slough bass muscle and whitefish muscle because of interest in this persistent man-made radionuclide in the environment. Because of a relatively large proportion of negative values, the application of parametric analyses was limited to ANOVA of carp muscle samples and regression analysis for trends of log-transformed median ${ }^{137} \mathrm{Cs}$ concentrations. Appendix B contains ANOVA tables for log-transformed ${ }^{90} \mathrm{Sr}$ and ${ }^{137} \mathrm{Cs}$ data comparisons. No other man-made radionuclide routinely measured by gamma spectroscopy, ${ }^{99} \mathrm{Tc}$, or uranium isotopes, was present in measurable quantities, and a statistical analysis was not performed. Concentrations of ${ }^{90} \mathrm{Sr}$ and ${ }^{137} \mathrm{Cs}$ in salmon samples were predominantly less than detection limits, and statistical analyses were not done.

\section{TREND ANALYSIS}

Strontium-90 and ${ }^{137} \mathrm{Cs}$ trends were evaluated in bass samples collected from F Slough. Data from Priest Rapids and the 100-N to 100-D Areas were combined to establish median concentrations of ${ }^{90} \mathrm{Sr}$ and ${ }^{137} \mathrm{Cs}$ for trend analysis of whitefish samples [ANOVA for location effects demonstrated that tissue concentrations in whitefish from these two locations were not different (see Location Effects, p. 34)]. Data have been presented in box plots. Tissue concentrations were related to time and reported Site releases of radionuclides to the Columbia River.

\section{Bass}

Trend analysis was conducted for ${ }^{90} \mathrm{Sr}$ in muscle and carcass and for ${ }^{137} \mathrm{Cs}$ in muscle. Five bass samples were collected every year from 1983 through 1992 except 1991.

\section{Muscle - Strontium-90}

Strontium- 90 was measured at very low levels in $29 \%$ of the 45 muscle samples collected from 1983 to 1992 at F Slough (Figure 5), and additional statistical analyses were not performed. These data suggest an increase from 1983 through 1986, followed by a decline over subsequent years; however, only 3 of 45 measurements were definitive (Table 2). 
TABLE 2. Screening Evaluation of Ratios of Total Analytical Error/Concentration for Fish Results

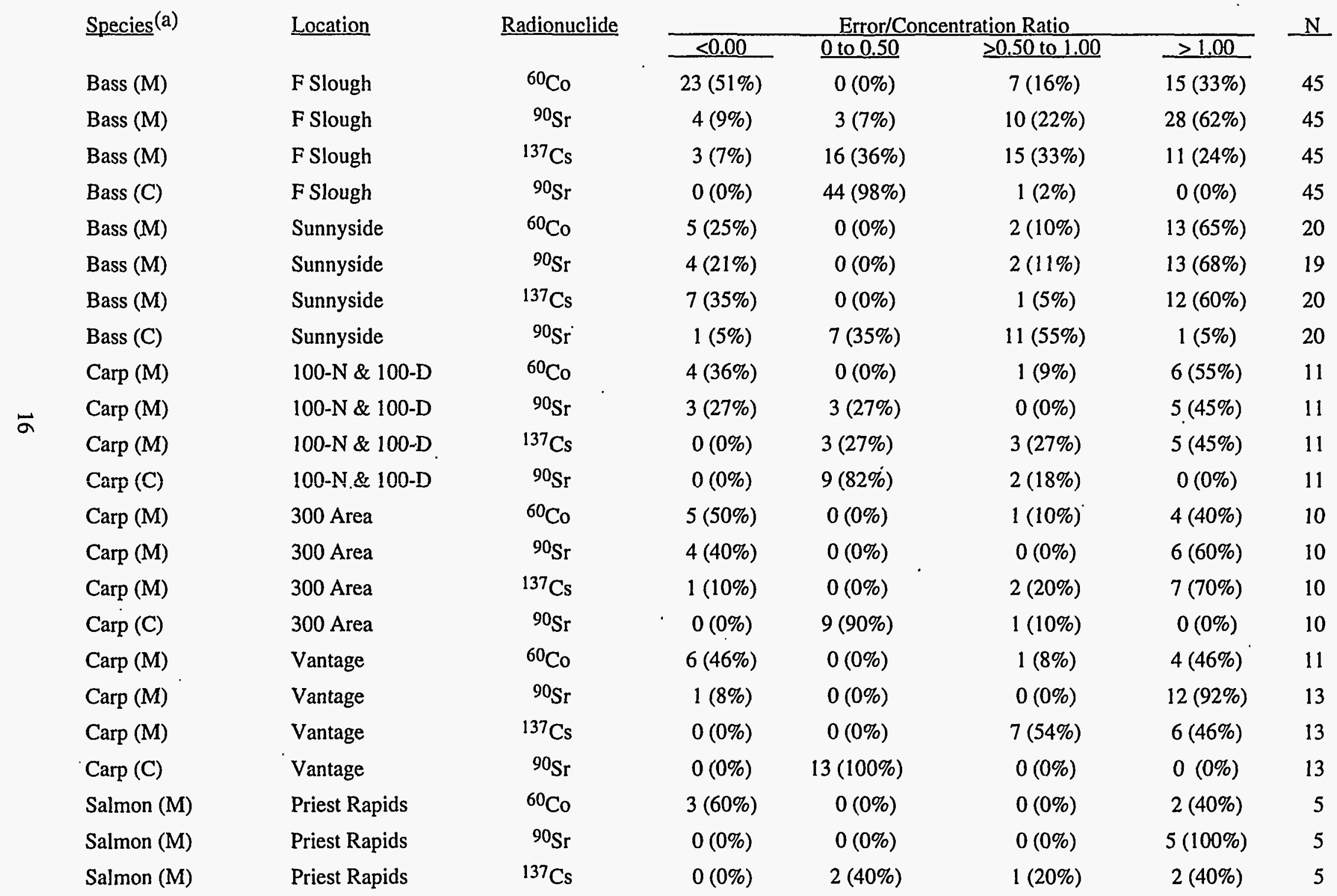


TABLE 2. (contd)

$\begin{array}{ll}\text { Species }^{(a)} & \text { Location } \\ & \\ \text { Salmon (M) } & 100 \mathrm{~F} \\ \text { Salmon (M) } & 100 \mathrm{~F} \\ \text { Salmon (M) } & 100 \mathrm{~F} \\ \text { Whitefish (M) } & 100-\mathrm{N} \& 100-\mathrm{D} \\ \text { Whitefish (M) } & 100-\mathrm{N} \& 100-\mathrm{D} \\ \text { Whitefish (M) } & 100-\mathrm{N} \& 100-\mathrm{D} \\ \text { Whitefish (C) } & 100-\mathrm{N} \& 100-\mathrm{D} \\ \text { Whitefish (M) } & \text { Priest Rapids } \\ \text { Whitefish (M) } & \text { Priest Rapids } \\ \text { Whitefish (M) } & \text { Priest Rapids } \\ \text { Whitefish (C) } & \text { Priest Rapids } \\ \text { Whitefish (M) } & 300 \text { Area } \\ \text { Whitefish (M) } & 300 \text { Area } \\ \text { Whitefish (M) } & 300 \text { Area } \\ \text { Whitefish (C) } & 300 \text { Area } \\ \text { Whitefish (M) } & \text { Kettle River } \\ \text { Whitefish (M) } & \text { Kettle River } \\ \text { Whitefish (M) } & \text { Kettle River } \\ \text { Whitefish (C) } & \text { Kettle River }\end{array}$

$\underline{\text { Radionuclide }}$

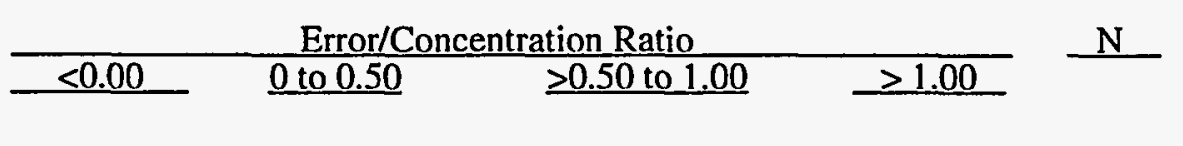

$\begin{array}{lcccrr}{ }^{60} \mathrm{Co} & 2(40 \%) & 0(0 \%) & 0(0 \%) & 3(60 \%) & 5 \\ { }^{90} \mathrm{Sr} & 2(40 \%) & 0(0 \%) & 0(0 \%) & 3(60 \%) & 5 \\ { }^{137} \mathrm{Cs} & 1(20 \%) & 0(0 \%) & 3(60 \%) & 1(20 \%) & 5 \\ { }^{60} \mathrm{Co} & 28(26 \%) & 1(0.9 \%) & 25(23 \%) & 54(50 \%) & 108 \\ { }^{90} \mathrm{Sr} & 15(15 \%) & 10(10 \%) & 31(31 \%) & 45(45 \%) & 101 \\ { }^{137} \mathrm{Cs} & 13(12 \%) & 14(13 \%) & 32(30 \%) & 49(45 \%) & 108 \\ { }^{90} \mathrm{Sr} & 1(1 \%) & 89(92 \%) & 5(5 \%) & 2(2 \%) & 97 \\ { }^{60} \mathrm{Co} & 13(27 \%) & 1(2 \%) & 6(13 \%) & 28(58 \%) & 48 \\ { }^{90} \mathrm{Sr} & 8(19 \%) & 5(12 \%) & 12(28 \%) & 18(42 \%) & 43 \\ { }^{137} \mathrm{Cs} & 14(29 \%) & 3(6 \%) & 11(23 \%) & 20(42 \%) & 48 \\ { }^{90} \mathrm{Sr} & 0(0 \%) & 37(93 \%) & 1(3 \%) & 2(5 \%) & 40 \\ { }^{60} \mathrm{Co} & 6(35 \%) & 0(0 \%) & 1(6 \%) & 10(59 \%) & 17 \\ { }^{90} \mathrm{Sr} & 4(14 \%) & 11(29 \%) & 6(21 \%) & 8(28 \%) & 29 \\ { }^{137} \mathrm{Cs} & 3(18 \%) & 0(0 \%) & 3(18 \%) & 11(65 \%) & 17 \\ { }^{90} \mathrm{Sr} & 0(0 \%) & 5(100 \%) & 0(0 \%) & 0(0 \%) & 5 \\ { }^{60} \mathrm{Co} & 7(78 \%) & 0(0 \%) & 2(22 \%) & 0(0 \%) & 9 \\ { }^{90} \mathrm{Sr} & 2(22 \%) & 0(0 \%) & 0(0 \%) & 7(78 \%) & 9 \\ { }^{137} \mathrm{Cs} & 3(33 \%) & 0(0 \%) & 1(11 \%) & 5(56 \%) & 9 \\ { }^{90} \mathrm{Sr} & 0(0 \%) & 7(78 \%) & 2(22 \%) & 0(0 \%) & 9\end{array}$

(a) $\mathrm{M}=$ muscle, $\mathrm{C}=$ carcass. 


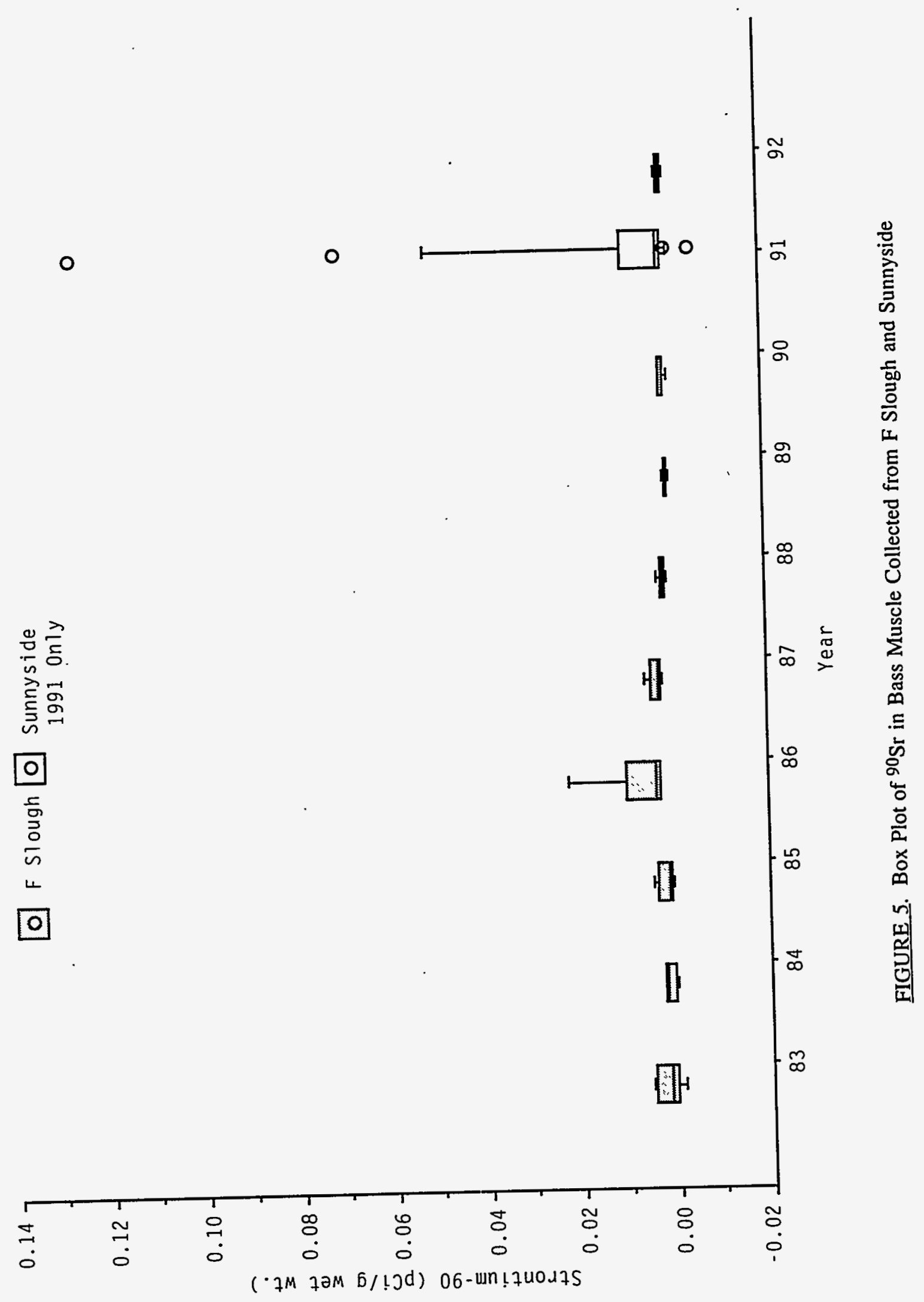




\section{Muscle-Cesium-137}

The median concentration of ${ }^{137} \mathrm{Cs}$ in bass muscle has generally decreased over the past 10 years (Figure 6). A small increase first noted in 1987 could be attributed to the Chernobyl accident in 1986; however, there is no way to trace the ${ }^{137} \mathrm{Cs}$ to this accident and it may reflect relatively elevated releases in 1984 and 1985 (see Figure 1).

Annual median ${ }^{137} \mathrm{C}$ s muscle concentrations were log-transformed and analyzed by Model I regression analysis. The Model I regression analysis of log-transformed median ${ }^{137} \mathrm{Cs}$ concentrations was significant $\left(P=0.010\right.$, Appendix $B$, Table B.1), indicating a general reduction in ${ }^{137} \mathrm{Cs}$ in bass muscle over the past 10 years. The second-order polynomial regression of the log-transformed median was also significant $(P=0.018)$, but did not indicate an improvement in fit compared to the linear model (Figure 7). A Model II regression of reported Site releases of ${ }^{137} \mathrm{Cs}$ to the Columbia River and tissue concentrations in bass was not significant $\left(P=0.185 ; R^{2}=0.236\right.$, Table B.2). These regression analyses indicate that the amount of ${ }^{137} \mathrm{Cs}$ found in bass muscle was not highly related to Hanford Site releases to the Columbia River.

\section{Carcass - Strontium-90}

A similar pattern of ${ }^{90} \mathrm{Sr}$ was observed in bass carcass as seen in muscle; however, concentrations were one to two orders of magnitude greater in carcass samples and there were no negative concentrations (Figure 8). The Model I regression analysis for trends in the bass carcass data was inconclusive ( $\mathrm{P}=$ 0.683, Table B.3) because of very low concentrations in 1983 and 1986 (see Figure 5). Generally,

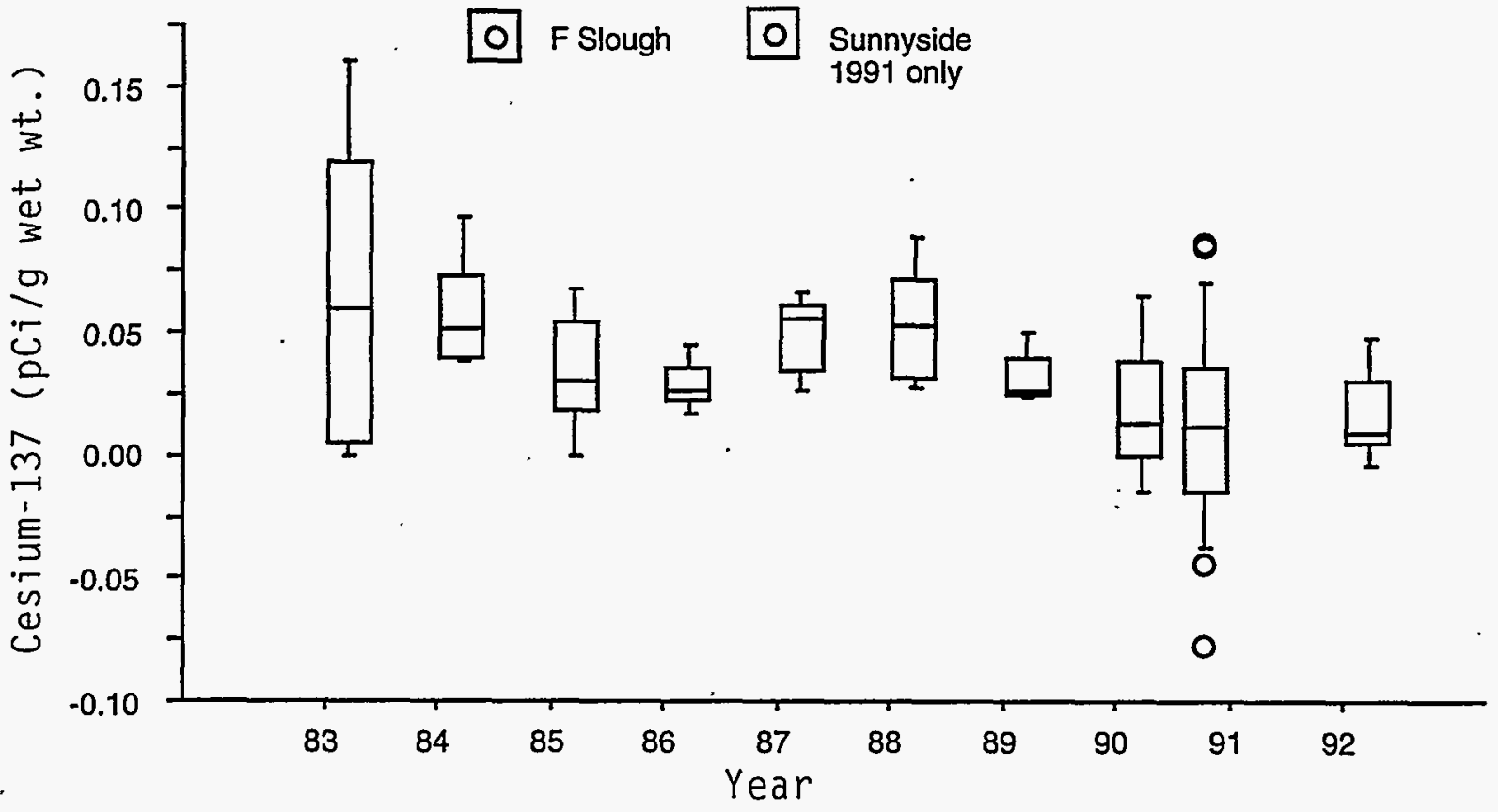

FIGURE 6. Box Plot of ${ }^{137} \mathrm{Cs}$ in Bass Muscle Collected from F Slough and Sunnyside 


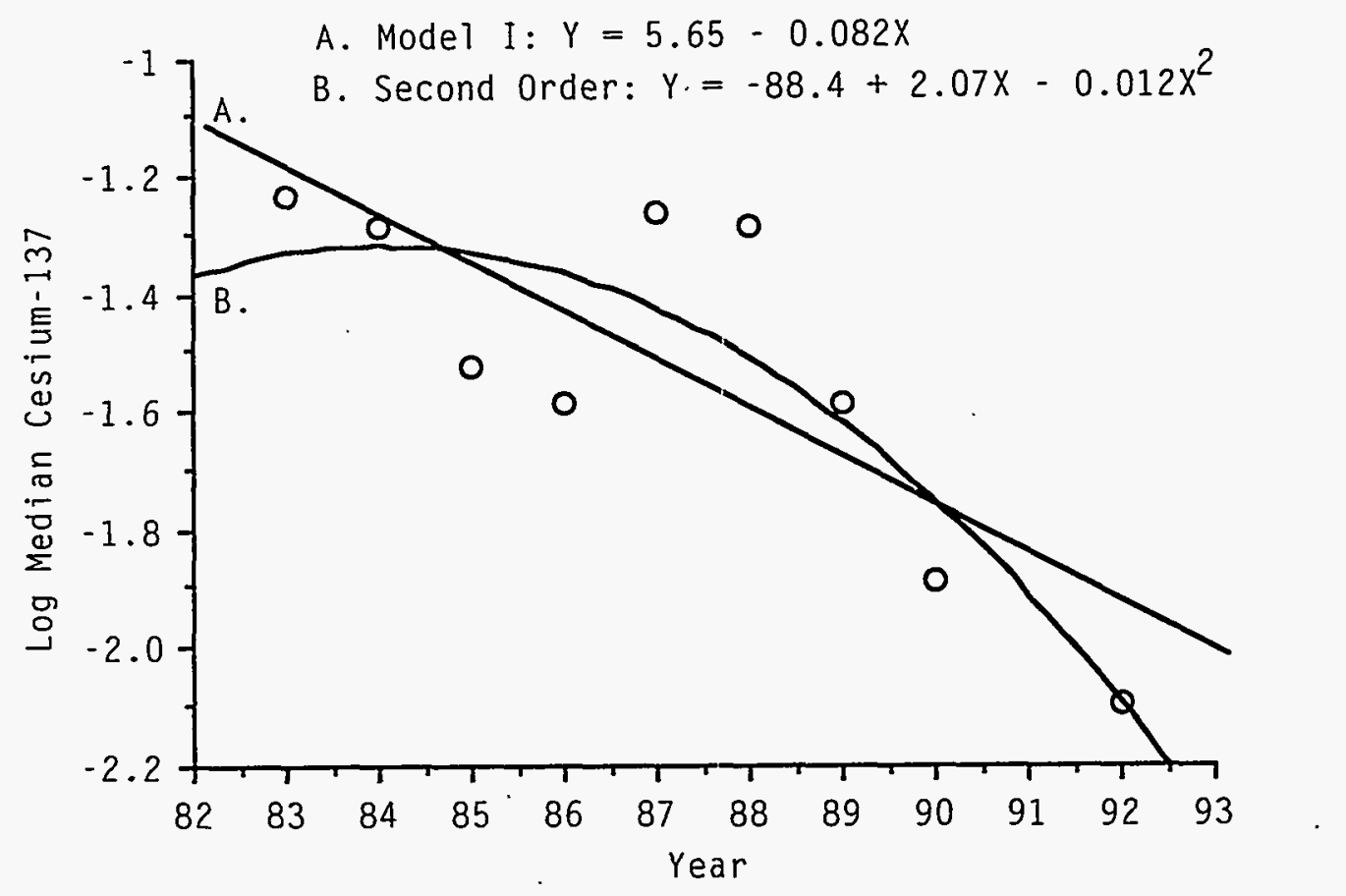

FIGURE 7. Model I and Second-Order Regression of Log-Transformed Median Concentrations of ${ }^{137} \mathrm{Cs}$ in Bass Muscle

concentrations of ${ }^{90} \mathrm{Sr}$ in bass carcass followed the pattern of releases to the Columbia River (see Figure 1); however, very low median carcass ${ }^{90} \mathrm{Sr}$ concentrations in 1983 and 1986 perturbed the log-linear relationship. The second-order polynomial regression of log-transformed median concentration versus year was also insignificant $(P=0.380$, Table B.3), as was the regression of log-transformed median carcass concentration versus ${ }^{90} \mathrm{Sr}$ releases $(P=0.839$, Table $B .4)$.

Collectively, the regression analyses demonstrate that there was no consistent relationship between Site releases of ${ }^{90} \mathrm{Sr}$ to the Columbia River or time with concentrations of ${ }^{90} \mathrm{Sr}$ in bass carcass.

\section{Whitefish}

Trend analyses of whitefish samples include ${ }^{137} \mathrm{Cs}$ and ${ }^{90} \mathrm{Sr}$ from 1982 through 1992. In 1992 , muscle samples were also analyzed for ${ }^{99} \mathrm{Tc}$ and uranium isotopes to quantify the effects of seepwater discharges from the Hanford Townsite and 300 Area. Technetium-99 and uranium isotope concentrations are summarized in Appendix A.

\section{Muscle - Strontium-90}

Most median ${ }^{90} \mathrm{Sr}$ muscle concentrations were at or below the $\mathrm{MDC}$ for ${ }^{90} \mathrm{Sr}$ of $0.005 \mathrm{pCi} / \mathrm{g}$. Overall, the results were low and highly variable over the 11-year period (Figure 9). The data from Priest 


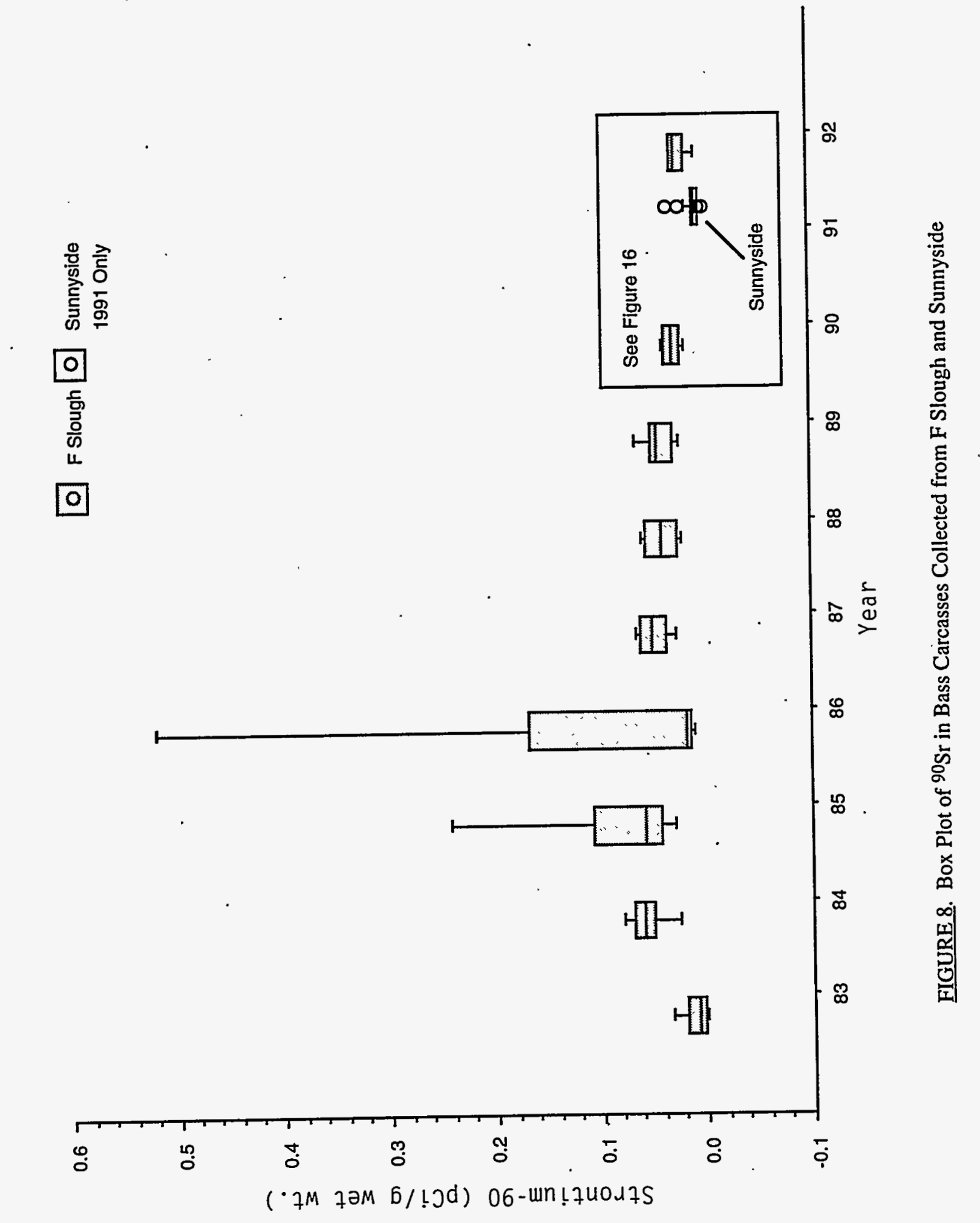



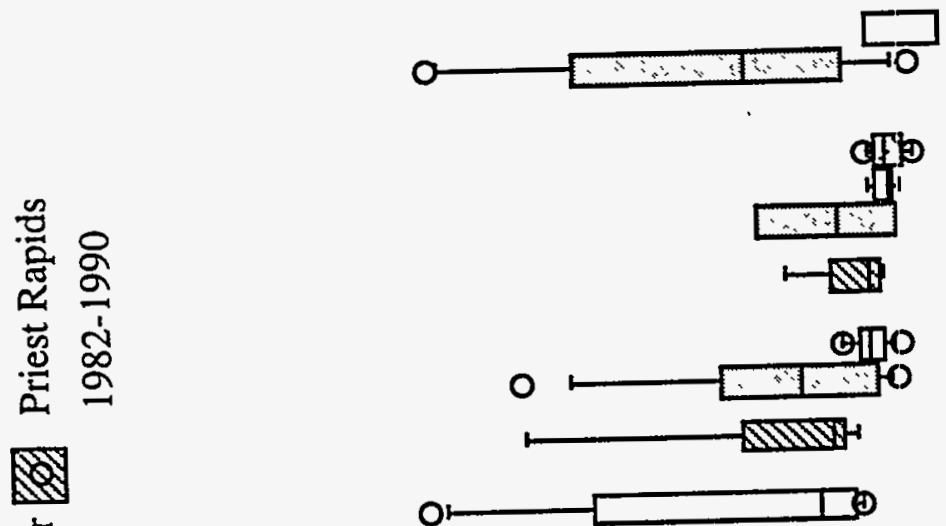

ส

过

क्]

咀

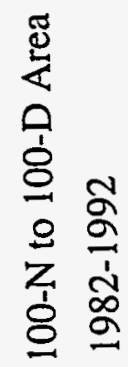

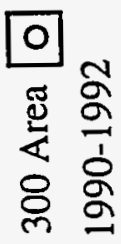

이 0
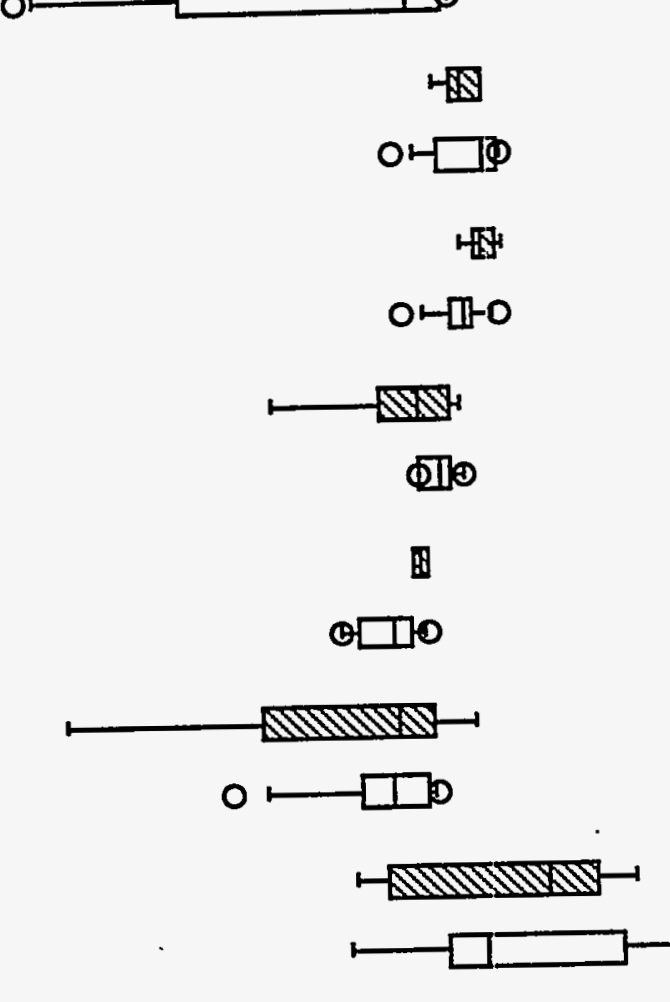

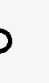

W

$\circ$
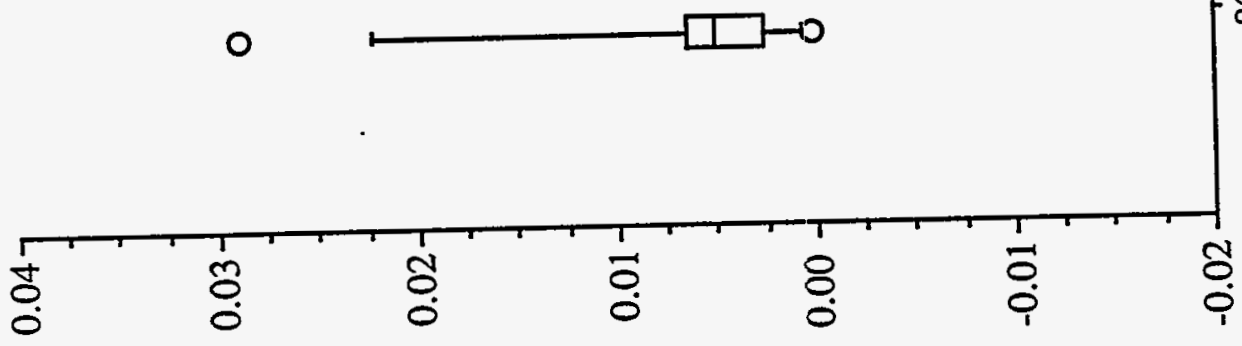

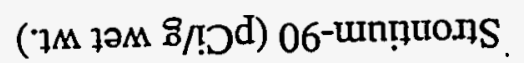


Rapids and 100-N to 100-D Areas were combined, and the median concentrations for each year were determined. The Model I regression analysis of log-transformed median ${ }^{90} \mathrm{Sr}$ concentrations in whitefish muscle versus year was significant $\left(P=0.024\right.$, Table B.5), indicating a general reduction in ${ }^{90} \mathrm{Sr}$ in whitefish muscle over the past 11 years. The second-order polynomial regression of log-transformed median concentration versus year was insignificant $(P=0.089)$, suggesting that concentrations in whitefish muscle did not reflect reported releases (Figure 10). The Model $\Pi$ regression of logtransformed median carcass concentration versus ${ }^{90} \mathrm{Sr}$ releases (Figure 11 ), however, was significant $(\mathrm{P}=0.048$, Table B.6).

Collectively, the regression analyses suggest that there was a log-linear decrease in ${ }^{90} \mathrm{Sr}$ in whitefish muscle over time which corresponded with Site releases of ${ }^{90} \mathrm{Sr}$ to the Columbia River. Median ${ }^{90} \mathrm{Sr}$ concentrations in 1983 and 1992 were excluded from the analysis because they were negative. Consequently, the relationships discussed here are marginal. Strontium-90 measured in muscle is probably associated with small bones, and analysis of carcass samples for ${ }^{90} \mathrm{Sr}$ is more indicative of accumulation patterns of ${ }^{90} \mathrm{Sr}$ in whitefish.

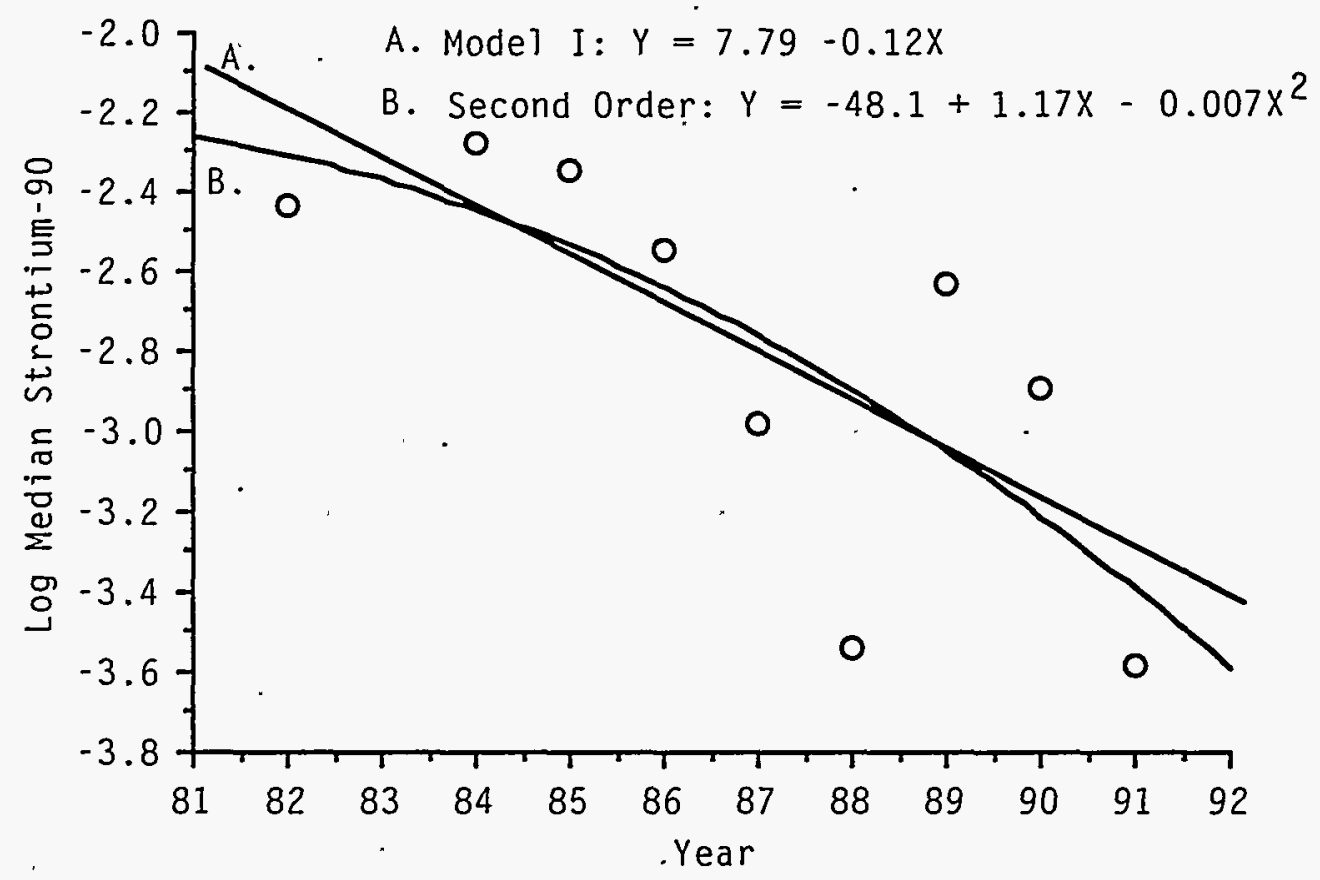

FIGURE 10. Model I and Second-Order Regression of Log-Transformed Median Concentrations of ${ }^{90} \mathrm{Sr}$ in Whitefish Muscle 


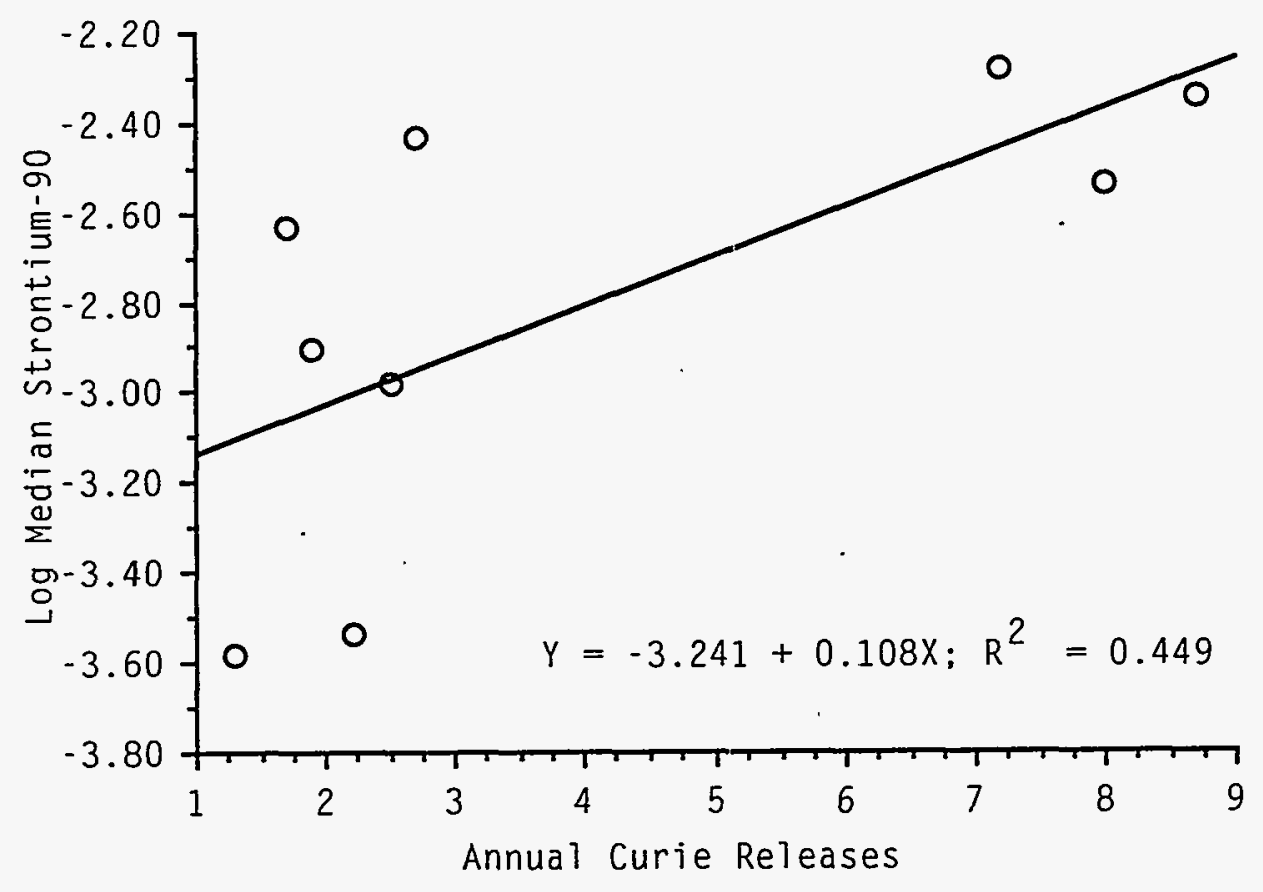

FIGURE 11. Model II Regression of Log-Transformed Median Concentrations of ${ }^{90} \mathrm{Sr}$ in Whitefish Muscle versus Annual Releases of ${ }^{90} \mathrm{Sr}$

\section{Muscle-Cesium-137}

Cesium-137 was measured in $43 \%$ of whitefish muscle samples collected from the $100-\mathrm{N}$ and 100-D Areas. Median concentrations were generally less than $0.03 \mathrm{pCi} / \mathrm{g}$ and showed no indication of any change over the past 11 years (Figure 12). The data from Priest Rapids and 100-N to 100-D Areas were combined and regressed against sampling year. Neither the simple nor the second-order regression analysis of log-transformed median ${ }^{137} \mathrm{Cs}$ concentrations in whitefish muscle by year was significant $(\mathrm{P}=$ 0.485 and 0.640 , respectively, Table B.7). The Model II regression of ${ }^{137} \mathrm{Cs}$ Site releases versus $\log$ transformed median ${ }^{137} \mathrm{Cs}$ muscle concentration also was not significant $(\mathrm{P}=0.163$, Table $\mathrm{B} .8)$.

Collectively, the regression analyses failed to demonstrate any significant relationship between concentrations of ${ }^{137} \mathrm{Cs}$ in whitefish muscle over time and with releases of ${ }^{137} \mathrm{Cs}$ to the Columbia River.

\section{Carcass - Strontium-90}

Strontium-90 was measured in nearly all whitefish carcass samples analyzed from 1982 through 1992 (see Table 2), and these measurements provide the most rigorous data base for evaluating trends of ${ }^{90} \mathrm{Sr}$ in Hanford Reach fish. Generally, there appears to be an increase in concentrations of ${ }^{90} \mathrm{Sr}$ in carcass followed by a gradual decrease after peaking in 1985-1986 (Figure 13).

Strontium concentrations were evaluated by combining the Priest Rapids and 100-N to $100-\mathrm{D}$ Area data and regressing the log-transformed median concentration by year. The Model I regression was 


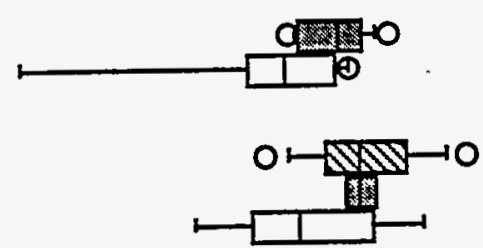

$\circ$

$\frac{\lambda}{5}$

崩

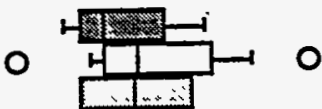

$\stackrel{6 \square}{\square \square}$

ro

\&

$<\dot{8}$

용 욕

\%

○
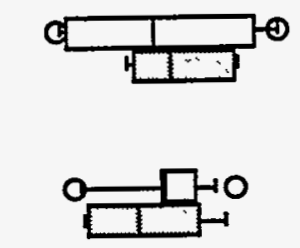

官

이

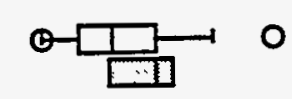

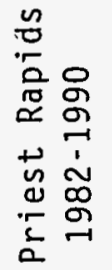

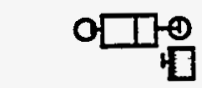

웅

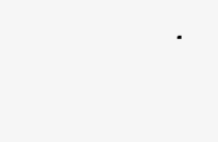

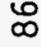

$\infty$

용

$\infty$

$\infty$ 尔

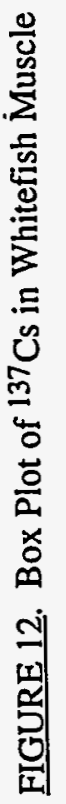

이

o

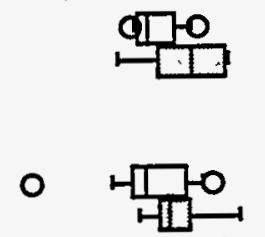

古

$\stackrel{\llcorner}{\infty}$

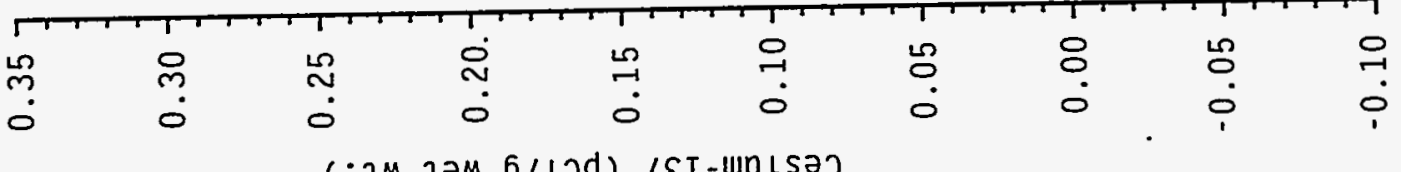

$(\cdot 7 M$ дәм $6 / ! \jmath d)<\varepsilon I-U n ! s \ni J$ 


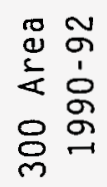

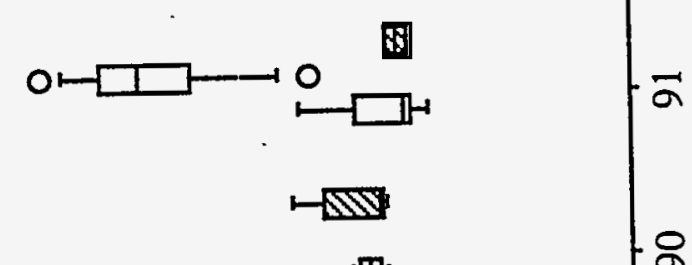

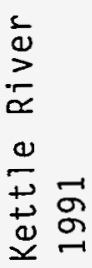

0
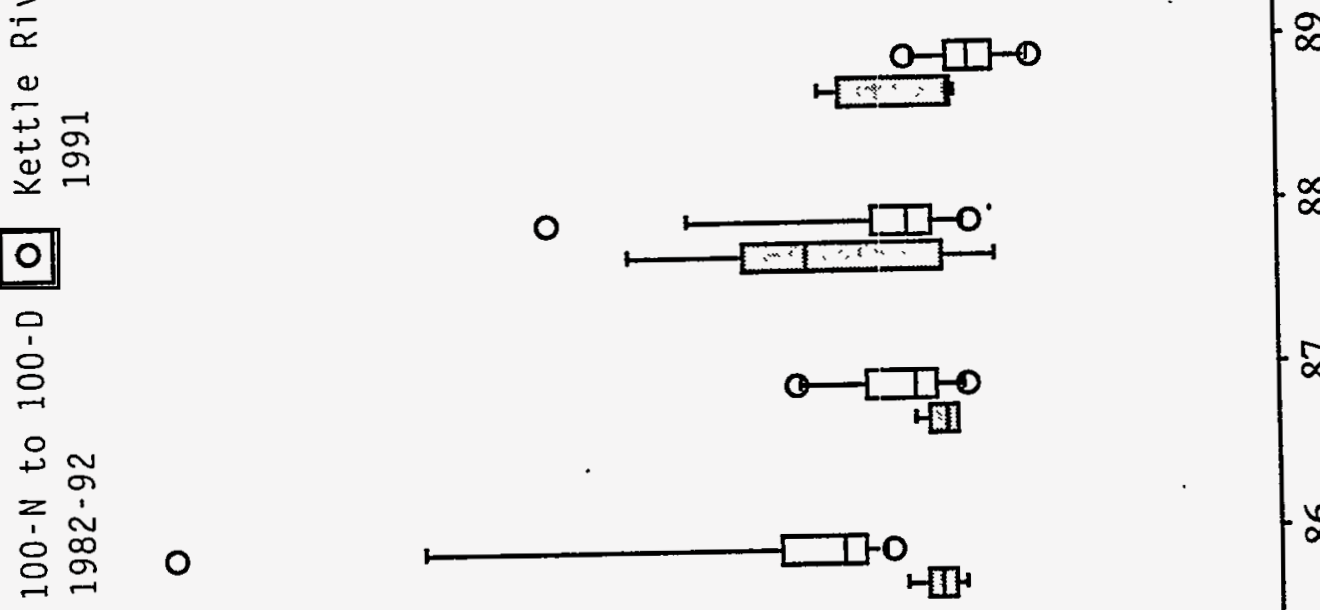

0

$\frac{0}{0}$

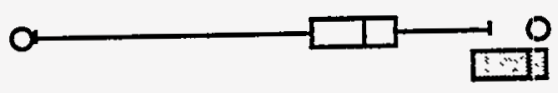

+ 용

a d

$-\infty$

ㄴ.

0

0

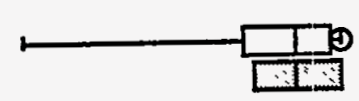

I

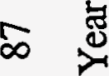

$\infty$

$\infty$

임ำ

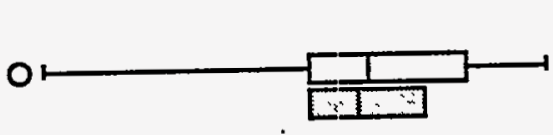

$a$

पा?

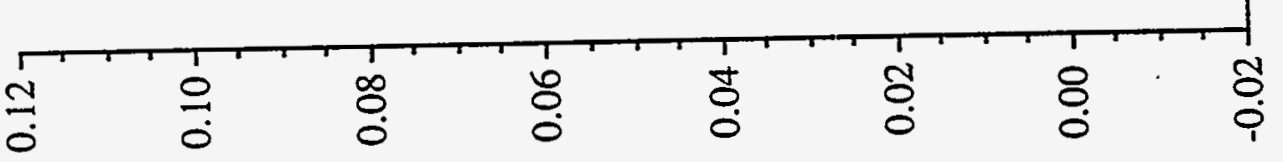

( 1 M 
significant $(P=0.007$, Table $B .9)$. A second-order regression indicated that a parabolic model was a better fit $(P=0.003)$ for the log-transformed median concentrations (Figure 14). Strontium-90

concentrations in whitefish carcass followed the pattern of Site releases to the Columbia River (see Figure 1). There was a strong correlation and significant regression ( $P=0.006$, Table $B .10)$ for log-transformed median ${ }^{90} \mathrm{Sr}$ in whitefish carcass versus amount of ${ }^{90} \mathrm{Sr}(\mathrm{Ci})$ released from the Site per year (Figure 15).

Collectively, the regression analyses indicate that concentrations of ${ }^{90} \mathrm{Sr}$ measured in Hanford Reach whitefish carcass accurately reflect reported releases to the Columbia River over the 1982-through1992 time frame. The second-order regression equation provides the best fit of the data over time.

\section{LOCATION EFFECTS}

This section evaluates differences in concentrations of ${ }^{90} \mathrm{Sr}$ and ${ }^{137} \mathrm{Cs}$ in fish collected from the Hanford Reach and background locations from 1988 through 1992. Differences among discrete years were also evaluated.

\section{$\underline{\text { Bass }}$} Washington.

Bass were collected from two locations: F Slough and a background pond in Sunnyside,

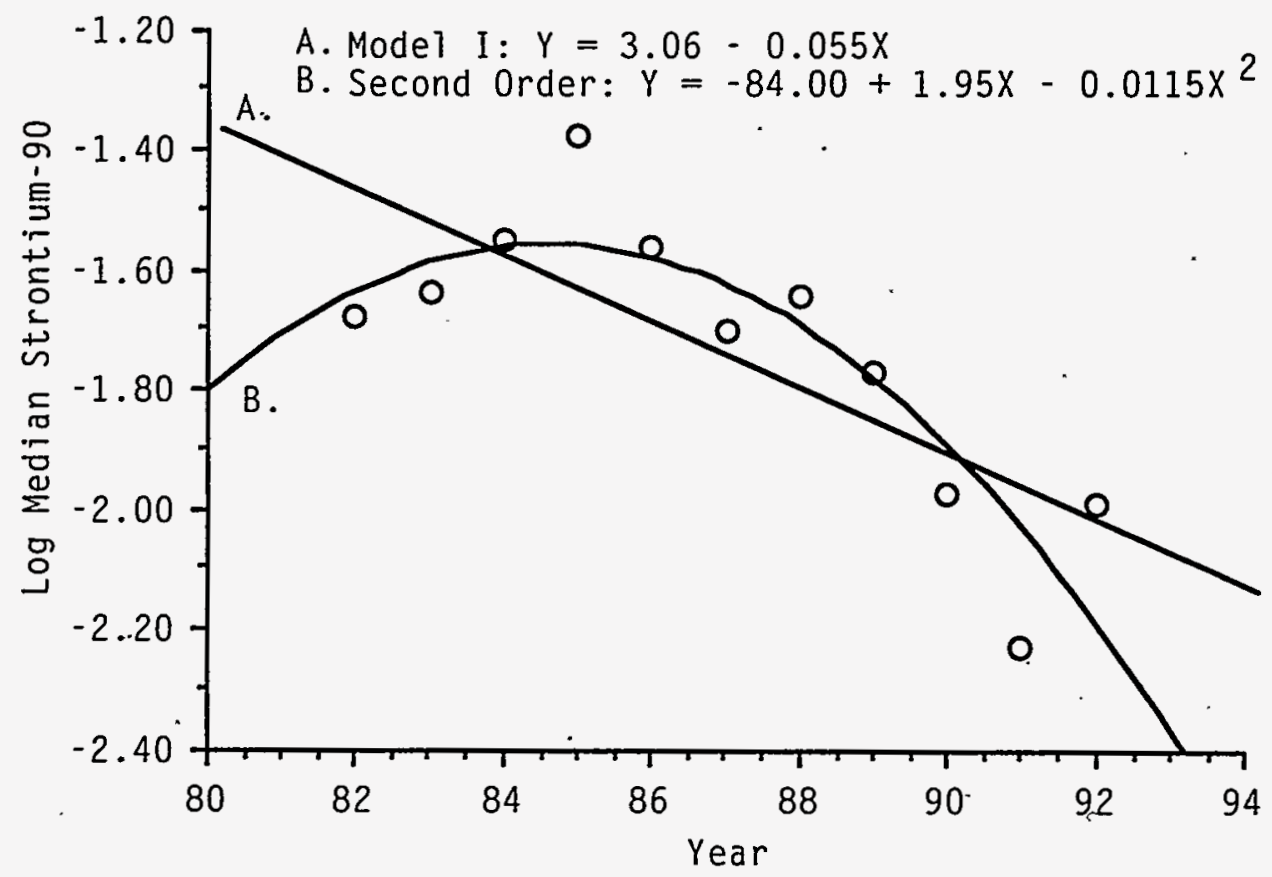

FIGURE 14. Model I and Second-Order Regression of Log-Transformed Median Concentrations of ${ }^{90} \mathrm{Sr}$ in Whitefish Carcass 


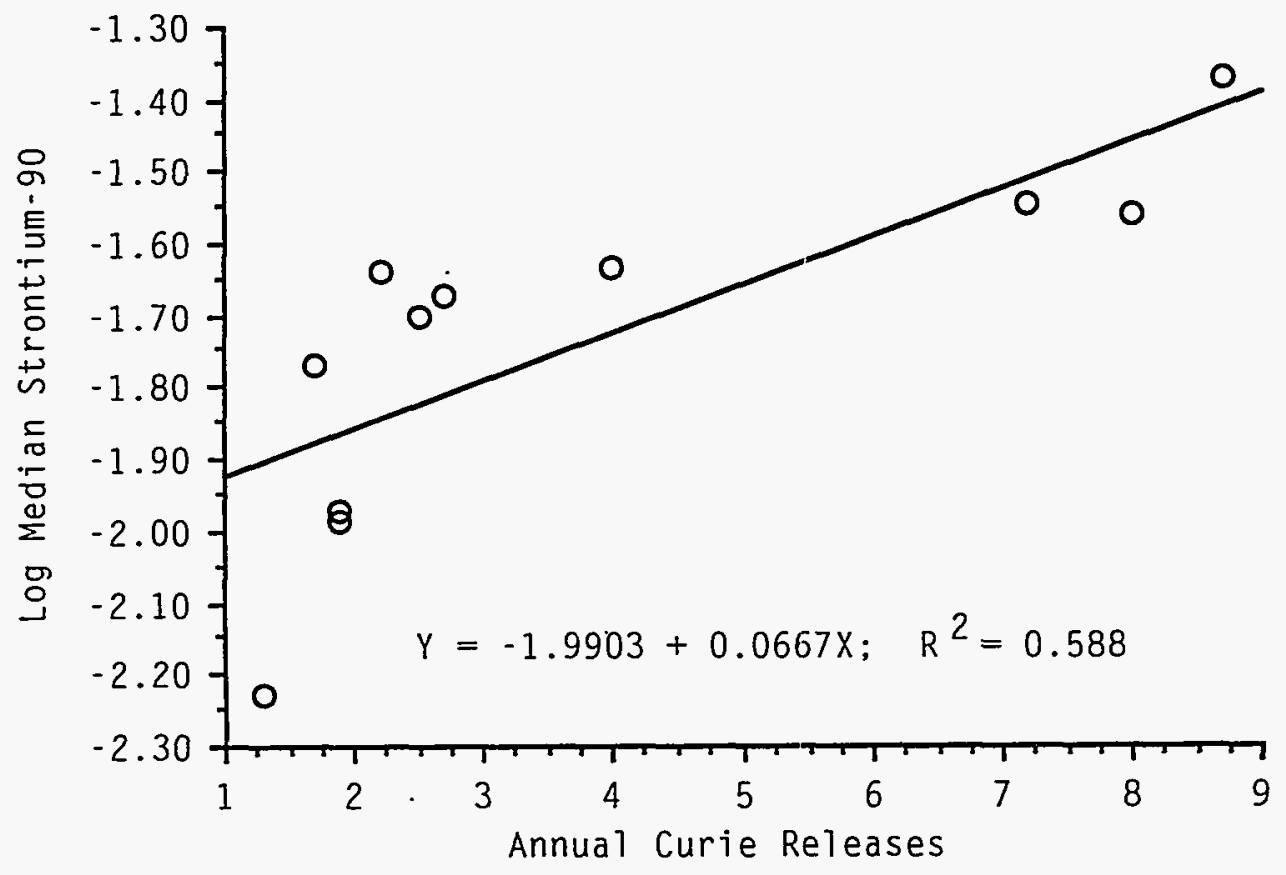

FIGURE 15. Model II Regression of Log-Transformed Median Concentrations of ${ }^{90} \mathrm{Sr}$ in Whitefish Carcass and Annual Releases of ${ }^{90} \mathrm{Sr}$

\section{Muscle - Strontium-90}

The data for Sunnyside bass muscle were highly variable, with two measurable concentrations reported of 19 samples analyzed (see Table 2 and Figure 5). The median concentrations for Sunnyside bass muscle and F Slough bass muscle samples collected from 1990 to 1992 were both $0.001 \mathrm{pCi}{ }^{90} \mathrm{Sr} / \mathrm{g}$, indicating no apparent difference between the background and F Slough locations.

\section{Muscle - Cesium-137}

The median concentration of ${ }^{137} \mathrm{Cs}$ in Sunnyside bass muscle in 1991 was similar to median levels measured in F Slough bass muscle in 1990 and 1992 (see Figure 6). ANOVA of log-transformed concentrations by location was not significant for the years 1990 to $1992(\mathrm{P}=0.423$, Table B.11). Most of the bass muscle samples had concentrations less than the MDC $(0.015$ to $0.02 \mathrm{pCi} / \mathrm{g})$ during these years, and Fisher's PLSD tests between any combination of years were not significant $(P \leq 0.05)$. Thirtyfive percent of the Sunnyside samples had negative values that were not used in the statistical analysis. No additional comparisons were made for location effects; however, inspection of the 1990-through-1992 data suggests no difference between locations for that time period. 


\section{Carcass - Strontium-90}

The median concentration of ${ }^{90} \mathrm{Sr}$ in bass carcass collected from Sunnyside was $0.005 \mathrm{pCi} / \mathrm{g}$, compared with $0.027 \mathrm{pCi} / \mathrm{g}$ in bass carcass in the 10 fish collected in 1990 and 1992 from F Slough (Figure 16). An ANOVA of log-transformed carcass concentrations of ${ }^{90} \mathrm{Sr}$ from 1990 to 1992 for $\mathrm{F}$. Slough and Sunnyside was significant $\left(\mathrm{P}<0.0001\right.$, Table B.12). The log-transformed mean for ${ }^{90} \mathrm{Sr}$ in Sunnyside bass carcass was significantly less than the log-transformed mean for ${ }^{90} \mathrm{Sr}$ in F Slough bass collected in 1990 and 1992 (Table B.13). This difference, while highly significant, does not necessarily indicate a Hanford effect on bass at F Slough, because the concentration of ${ }^{90} \mathrm{Sr}$ in the Sunnyside pond water and sediment is unknown and may be different than conditions upstream of Hanford in the Columbia River.

ANOVA of the log-transformed F Slough data (1983 through 1992) by year was significant $(P=$ 0.0064, Table B.14). Fisher's PLSD test was applied to determine differences between log-transformed means. There were nine statistically significant differences among yearly pairs of means (Table 3 ). Strontium-90 concentrations in bass carcasses in 1983 were lower than all 8 years sampled subsequent to 1983 , and ${ }^{90} \mathrm{Sr}$ concentrations in 1985 were lower than 1992 concentrations.

\section{Carp}

Carp was first sampled in 1990 , and the time frame was too short to evaluate any potential trends that may exist; however, comparisons were made with log-transformed data to determine differences among years and whether there was a Hanford effect.

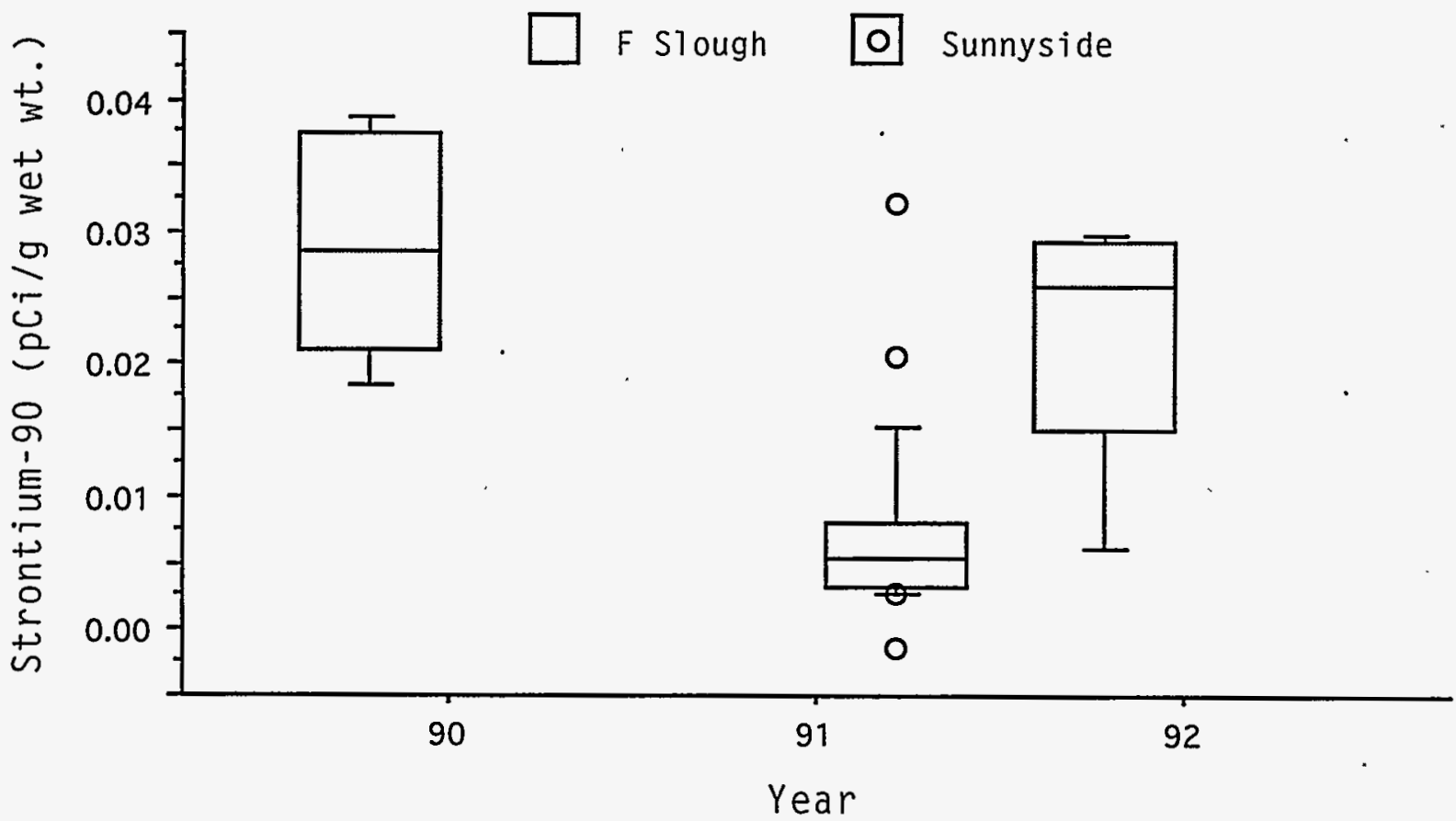

FIGURE 16. Box Plot of ${ }^{90} \mathrm{Sr}$ in Bass Carcasses Collected from F Slough and Sunnyside 
TABLE 3. Yearly Comparison of Statistically Significant Differences by Fisher's PLSD Comparisons of Log-Transformed Means of ${ }^{90} \mathrm{Sr}$ in Bass Carcass Collected from $\mathrm{F}$ Slough (other yearly comparisons not listed were not significant)

\begin{tabular}{|c|c|c|c|c|c|c|c|}
\hline \multicolumn{3}{|c|}{ Mean } & \multicolumn{3}{|c|}{ Mean } & \multicolumn{2}{|c|}{ PLSD } \\
\hline Year & $(\mathrm{pCi} / \mathrm{g})$ & Log-Mean & Year & $(\mathrm{pCi} / \mathrm{g})$ & Log-Mear & Diffe & P-Value \\
\hline$\overline{83}$ & 0.012 & -2.248 & 84 & 0.057 & -1.274 & -0.974 & 0.0004 \\
\hline 83 & 0.012 & -2.248 & 85 & 0.088 & -1.183 & -1.065 & 0.0001 \\
\hline 83 & 0.012 & -2.248 & 86 & 0.122 & -1.433 & -0.815 & 0.0023 \\
\hline 83 & 0.012 & -2.248 & 87 & 0.049 & -1.332 & -0.916 & 0.0007 \\
\hline 83 & 0.012 & -2.248 & 88 & 0.040 & -1.427 & -0.820 & 0.0021 \\
\hline 83 & 0.012 & -2.248 & 89 & 0.042 & -1.404 & -0.843 & 0.0017 \\
\hline 83 & 0.012 & -2.248 & 90 & 0.029 & -1.557 & -0.691 & 0.0085 \\
\hline 83 & 0.012 & -2.248 & 92 & 0.022 & -1.721 & -0.527 & 0.0406 \\
\hline 85 & 0.088 & -1.135 & 92 & 0.022 & -1.721 & 0.538 & 0.0367 \\
\hline
\end{tabular}

\section{Muscle - Cesium-137}

Cesium-137 was measured in 54\% of the carp muscle samples collected from 1990 through 1992 at Vantage and between the $100-\mathrm{N}$ and $100-\mathrm{D}$ Areas (see Table 2). The MDC for ${ }^{137} \mathrm{Cs}$ was $0.015 \mathrm{pCi} / \mathrm{g}$ in 1990 samples and $0.02 \mathrm{pCi} / \mathrm{g}$ in 1991 and 1992 samples; however, many of the measured concentrations were below the MDCs (Figure 17). The ANOVA of ${ }^{137} \mathrm{Cs}$ by location was significant $(P=0.044$, Table B.15). Scheffé's multiple comparison test was used because of the addition of sample collection locations in different years. Scheffé's multiple comparison was significant for the $100-\mathrm{N}$ to 100-D Areas comparison with Vantage, suggesting a potential Hanford effect (Table 4). Other combinations of locations were not significant. There was no difference in ${ }^{137} \mathrm{Cs}$ concentrations between years at any location (P>0.40, Table B.16).

\section{Carcass - Strontium-90}

Strontium-90 was routinely monitored in carp carcasses from 1990 to 1992 (Figure 18). Background samples were collected in 1990 and 1991 at Vantage, Washington. Based on ANOVA of log-transformed data $(P=0.035$, Table B.17) and Scheffé's multiple comparisons test, log-transformed mean ${ }^{90} \mathrm{Sr}$ concentrations in background carp carcasses collected from Vantage were significantly greater than log-transformed mean concentrations measured at the 300 Area in 1991 and 1992 (Table 5). There were no statistically significant differences between ${ }^{90} \mathrm{Sr}$ in carp carcasses from the $100-\mathrm{N}$ to 100 -D Areas and Vantage. ANOVA of log-transformed data by location and year indicated no significant differences between years at the three locations sampled $(P>0.060$, Table B.18). Collectively, these data suggest no Hanford Site impact from ${ }^{90} \mathrm{Sr}$ in carp.

Median levels of ${ }^{90} \mathrm{Sr}$ in carp collected from the 100-N and 100-D Areas during these years were similar to the median carcass concentrations in F Slough bass $(0.027 \mathrm{pCi} / \mathrm{g})$; however, ${ }^{90} \mathrm{Sr}$ concentrations in bass carcass were an order of magnitude higher in 1986 (see Figure 8) and in a carp carcass collected from the 100-N Area in 1990. These observations suggest that fish were exposed to elevated concentrations of ${ }^{90} \mathrm{Sr}$ in the Columbia River. 


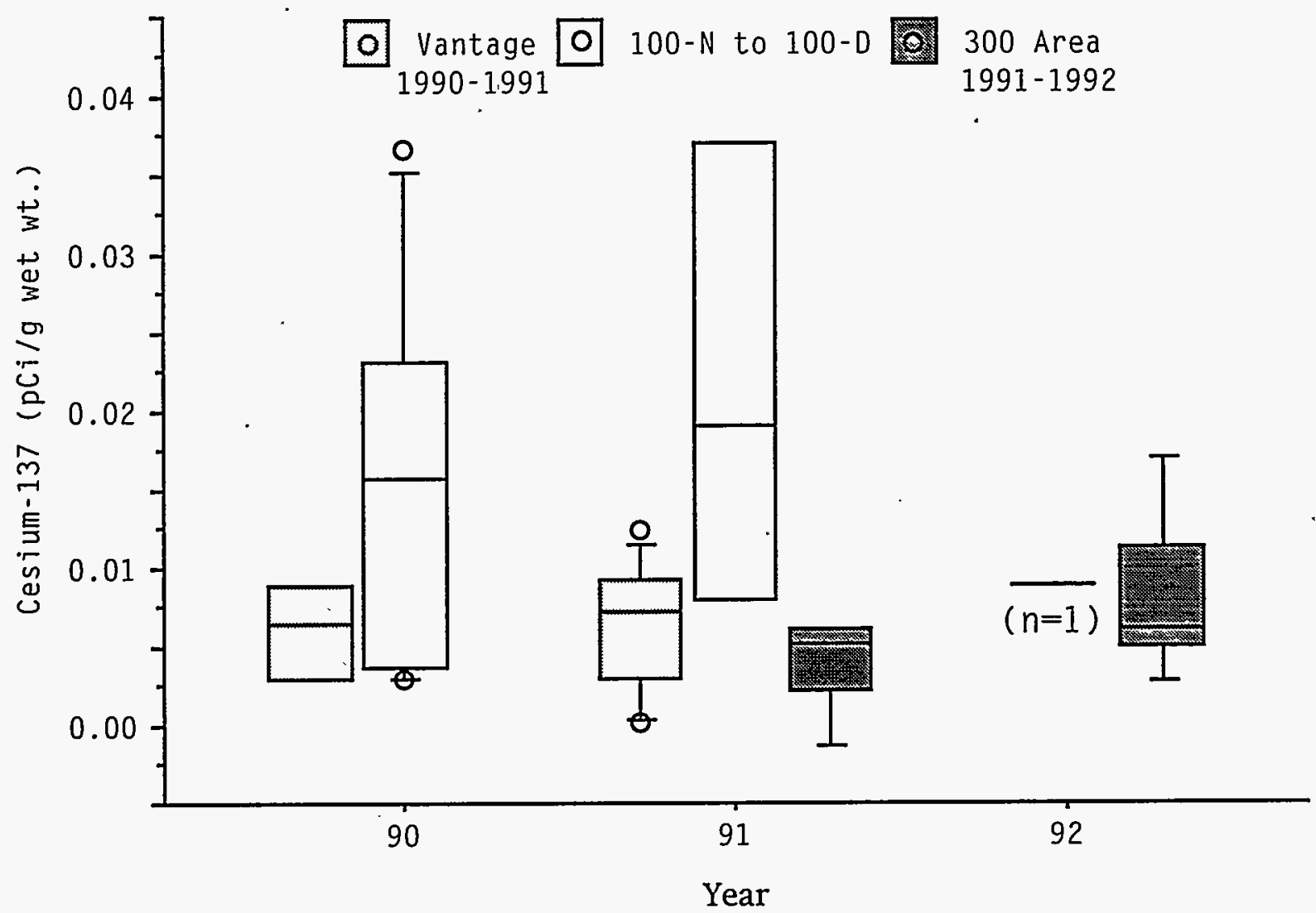

FIGURE 17. Box Plot of ${ }^{137} \mathrm{Cs}$ in Carp Muscle

TABLE 4. Scheffé's Comparisons of Log-Transformed Means of ${ }^{137}$ Cs in Carp Muscle by Location, 1990 Through 1992

\begin{tabular}{|c|c|c|c|c|c|c|}
\hline $\begin{array}{l}\frac{\text { Location }}{100-N \text { to }} \\
100-D\end{array}$ & $\frac{N}{11}$ & $\begin{array}{l}\text { Mean } \\
\mathrm{pCi} / \mathrm{g} \\
0.018\end{array}$ & $\frac{\text { Log-Mean }}{-1.890}$ & $\begin{array}{c}\begin{array}{c}\text { Location } \\
\text { Comparison }\end{array} \\
300 \text { Area } \\
(-2.225)^{(a)}\end{array}$ & $\begin{array}{c}\text { Log-Mean } \\
\text { Difference } \\
0.335\end{array}$ & $\begin{array}{l}\text { Scheffé's } \\
\frac{\text { P-Value }}{0.2289}\end{array}$ \\
\hline $\begin{array}{l}100-\mathrm{N} \text { to } \\
100-\mathrm{D}\end{array}$ & 11 & 0.018 & -1.890 & $\begin{array}{l}\text { Vantage } \\
(-2.337)\end{array}$ & 0.446 & 0.0505 \\
\hline 300 Area & 9 & 0.006 & -2.225 & $\begin{array}{l}\text { Vantage } \\
(-2.337)\end{array}$ & 0.112 & 0.8328 \\
\hline Vantage & 13 & 0.007 & -2.337 & -- & -- & -- \\
\hline
\end{tabular}

(a) Value in () is the log-mean ${ }^{137} \mathrm{Cs}$ concentration for the comparison. 


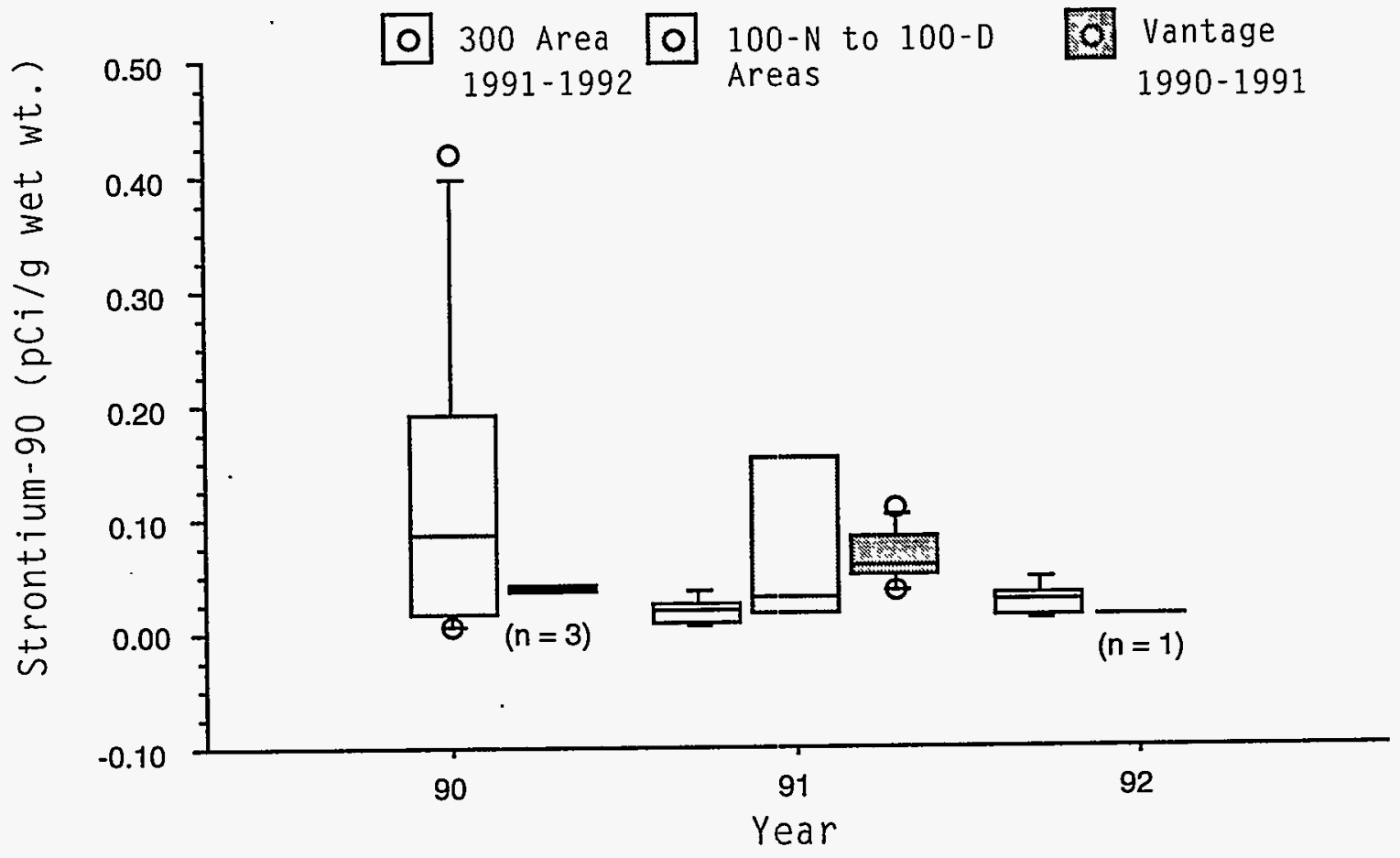

FIGURE 18. Box Plot of ${ }^{90}$ Sr in Carp Carcass

TABLE 5. Scheffé's Comparisons of Log-Transformed Means of ${ }^{90} \mathrm{Sr}$ in Carp Carcass by Location, 1990 Through 1992

\begin{tabular}{|c|c|c|c|c|c|c|}
\hline $\begin{array}{c}\frac{\text { Location }}{100-\mathrm{N} \text { to }} \\
100-\mathrm{D}\end{array}$ & $\frac{N}{11}$ & $\begin{array}{l}\text { Mean } \\
\text { pCi/g } \\
0.105\end{array}$ & $\frac{\text { Log Mean }}{-1.384}$ & $\begin{array}{l}\begin{array}{c}\text { Location } \\
\text { Comparison }\end{array} \\
\text { 300 Area } \\
(-1.730)^{(a)}\end{array}$ & $\begin{array}{l}\text { Log-Mean } \\
\text { Difference } \\
0.345\end{array}$ & $\begin{array}{l}\text { Scheffé's } \\
\text { P-Value } \\
0.1806\end{array}$ \\
\hline $\begin{array}{l}100-\mathrm{N} \text { to } \\
100-\mathrm{D}\end{array}$ & 11 & 0.105 & -1.384 & $\begin{array}{l}\text { Vantage } \\
(-1.261)\end{array}$ & -0.123 & 0.7712 \\
\hline 300 Area & 10 & 0.022 & -1.730 & $\begin{array}{l}\text { Vantage } \\
(-1.261)\end{array}$ & -0.469 & 0.0395 \\
\hline Vantage & 13 & 0.059 & -1.261 & - & -- & -- \\
\hline
\end{tabular}

(a) Value in () is the log-mean ${ }^{90} \mathrm{Sr}$ concentration.

\section{$\underline{\text { Salmon }}$}

Fall chinook salmon were collected around the 100-F Area and Priest Rapids Dam in 1988 to address concerns about concentrations in sport fish harvest. The maximum concentration of ${ }^{137} \mathrm{Cs}$ was $0.05 \pm 0.02 \mathrm{pCi} / \mathrm{g}$ in a Priest Rapids fish; all other measurements of ${ }^{137} \mathrm{Cs}$ were not definitive. There was no apparent difference among locations. Strontium-90 was not detected in salmon muscle from either location. Carcass samples were not analyzed. The data are summarized in Appendix A. 


\section{Whitefish}

Whitefish were most frequently collected from the Priest Rapids Hatchery and 100-D Area. In 1990, the 100-N Area was added for routine monitoring. For this analysis, the 100- $\mathrm{N}$ and 100-D Areas were considered one sampling location. A small number of samples collected from Ringold and the Hanford Townsite in 1982 and 1983 were not used in the evaluations.

\section{Muscle - Strontium-90}

Strontium-90 was detected in $50 \%$ of the whitefish muscle samples collected from the 300 Area from 1990 through 1992, and comparisons were made with all other locations for the period of 1988 through 1992. The ANOVA of log-transformed data indicated significant differences by location $(\mathrm{P}=$ 0.0003 , Table B.19). The concentration of ${ }^{90} \mathrm{Sr}$ in Kettle River whitefish muscle was significantly lower than concentrations found in fish collected the 300 Area for the time period of 1988 through 1992 (Table 6), but differences were not significant for other Hanford Reach locations. These observations point to the problems inherent in evaluating concentrations of radionuclides in mobile populations of fish.

TABLE 6. Scheffé's Comparisons of Log-Transformed Means of ${ }^{90} \mathrm{Sr}$ in Whitefish Muscle by Location, 1988 Through 1992

\begin{tabular}{|c|c|c|c|c|c|c|}
\hline $\begin{array}{c}\text { Location } \\
100-\mathrm{N} \text { to } \\
100-\mathrm{D}\end{array}$ & $\frac{N}{31}$ & $\begin{array}{c}\text { Mean } \\
\frac{\mathrm{pCi} / \mathrm{g}}{0.002}\end{array}$ & $\frac{\text { Log Mean }}{-2.921}$ & $\begin{array}{c}\text { Location } \\
\text { Comparison } \\
\text { Kettle } \\
\text { River } \\
(-3.398)^{(a)}\end{array}$ & $\begin{array}{c}\text { Log-Mean } \\
\text { Difference } \\
0.477\end{array}$ & $\begin{array}{l}\text { Scheffé's } \\
\text { P-Value } \\
0.397\end{array}$ \\
\hline $\begin{array}{l}100-\mathrm{N} \text { to } \\
100-\mathrm{D}\end{array}$ & 31 & 0.002 & -2.921 & $\begin{array}{c}\text { Priest } \\
\text { Rapids } \\
(-2.784)\end{array}$ & -0.137 & 0.918 \\
\hline $\begin{array}{l}100-\mathrm{N} \text { to } \\
100-\mathrm{D}\end{array}$ & 31 & 0.002 & -2.921 & $\begin{array}{c}300 \text { Area } \\
(-2.324)\end{array}$ & -0.598 & 0.007 \\
\hline 300 Area & 25 & 0.008 & -2.324 & $\begin{array}{c}\text { Kettle } \\
\text { River } \\
(-3.398)\end{array}$ & 1.074 & 0.004 \\
\hline 300 Area & 25 & 0.008 & -2.324 & $\begin{array}{c}\text { Priest } \\
\text { Rapids } \\
(-2.784)\end{array}$ & 0.460 & 0.165 \\
\hline $\begin{array}{l}\text { Priest } \\
\text { Rapids }\end{array}$ & 15 & 0.003 & -2.784 & $\begin{array}{c}\text { Kettle } \\
\text { River } \\
(-3.398)\end{array}$ & 0.614 & 0.244 \\
\hline $\begin{array}{l}\text { Kettle } \\
\text { River } \\
\end{array}$ & 6 & 0.0002 & -3.398 & - & -- & -- \\
\hline
\end{tabular}

(a) Value in () is the log-mean ${ }^{90} \mathrm{Sr}$ concentration. 
Comparisons among years by location indicated significant differences at Priest Rapids and 100-N to 100-D Areas for log-transformed ${ }^{90} \mathrm{Sr}$ in whitefish muscle for the period of 1982 through 1992 (Table B.20). Comparisons between years within locations at Priest Rapids and at the 100-N to 100-D Areas on log-transformed means by Fisher's PLSD tests was not done because of negative values found in certain years that introduced a bias in the analysis.

\section{Muscle - Cesium-137}

Cesium-137 was measured in $43 \%$ of whitefish muscle samples collected from the $100-\mathrm{N}$ and 100-D Areas. While the median concentration of ${ }^{137} \mathrm{Cs}$ in Kettle River whitefish collected in 1991 (0.005 $\mathrm{pCi} / \mathrm{g}$ ) was less than the 5-year median concentrations in Hanford Reach whitefish (0.009), all median concentrations were close to or less than the MDC for ${ }^{137} \mathrm{Cs}$ by gamma spectroscopy. ANOVA of logtransformed concentrations of ${ }^{137} \mathrm{Cs}$ in muscle by location for 1988 through $1992(\mathrm{P}=0.061$, Table B.21) and by year within locations ( $P>0.31$, Table B.22) were not significant. While some data were lost from log-transformation of negative concentrations, this did not affect the conclusion of either ANOVA for ${ }^{137} \mathrm{Cs}$ in whitefish muscle.

\section{Carcass - Strontium-90}

ANOVA of log-transformed concentrations by locations was significant for data collected from 1988 through 1992 ( $P=0.0003$, Table B.23). Scheffé's multiple comparison of log-transformed means indicated that the Kettle River whitefish had more ${ }^{90} \mathrm{Sr}$ in carcass samples than the 100-N to 100-D Area and the 300 Area fish (Table 7). Additionally, the 300 Area ${ }^{90} \mathrm{Sr}$ concentrations in whitefish carcass were lower than those for the Priest Rapids whitefish.

The Priest Rapids and 100-N to 100-D Area data were analyzed separately for differences by year, and the ANOVA was significant for both locations $(P=0.0017$ and 0.0001 , respectively, Table B.24). Year-by-year comparisons at Priest Rapids and 100-N to 100-D Areas (Table B.25) suggest an increase in ${ }^{90} \mathrm{Sr}$ concentrations through the early 1980 s, followed by a decrease into the early $1990 \mathrm{~s}$, corroborating previously reported trend analyses in this report.

The median concentration of ${ }^{90} \mathrm{Sr}$ measured in Kettle River whitefish carcass $(0.035 \mathrm{pCi} / \mathrm{g})$ was distinctly greater than median values measured at the combined 100-N to $100-\mathrm{D}$ Areas since 1988 and the 300 Area in 1992. Elevated concentrations in Kettle River whitefish may reflect elevated exposure to ${ }^{90} \mathrm{Sr}$ resulting from historical fallout from atmospheric weapons testing. 
TABLE 7. Scheffé's Comparisons of Log-Transformed Means of ${ }^{90} \mathrm{Sr}$ in Whitefish Carcass by Location, 1988 Through 1992

\begin{tabular}{|c|c|c|c|c|c|}
\hline $\begin{array}{c}\frac{\text { Location }}{100-N \text { to }} \\
100-D\end{array}$ & $\frac{N}{35}$ & $\frac{\text { Log Mean }}{-1.863}$ & $\begin{array}{c}\begin{array}{c}\text { Location } \\
\text { Comparison }\end{array} \\
\text { Kettle } \\
\text { River } \\
(-1.476)^{(a)}\end{array}$ & $\begin{array}{l}\text { Log-Mean } \\
\text { Difference } \\
-0.386\end{array}$ & $\begin{array}{l}\text { Scheffé's } \\
\frac{P-V a l u e}{0.0004}\end{array}$ \\
\hline $\begin{array}{l}100-\mathrm{N} \text { to } \\
100-\mathrm{D}\end{array}$ & 35 & -1.863 & $\begin{array}{l}\text { Priest } \\
\text { Rapids } \\
(-1.715)\end{array}$ & -0.148 & 0.2213 \\
\hline $\begin{array}{l}100-\mathrm{N} \text { to } \\
100-\mathrm{D}\end{array}$ & 35 & -1.863 & $\begin{array}{c}300 \text { Area } \\
(-1.960)\end{array}$ & 0.096 & 0.5628 \\
\hline 300 Area & 17 & -1.960 & $\begin{array}{c}\text { Kettle } \\
\text { River } \\
(-1.476)\end{array}$ & -0.483 & $<0.0001$ \\
\hline 300 Area & 17 & -1.960 & $\begin{array}{l}\text { Priest } \\
\text { Rapids } \\
(-1.715)\end{array}$ & 0.245 & 0.0321 \\
\hline $\begin{array}{l}\text { Priest } \\
\text { Rapids }\end{array}$ & 15 & -1.715 & $\begin{array}{c}\text { Kettle } \\
\text { River } \\
(-1.476)\end{array}$ & -0.238 & 0.1123 \\
\hline $\begin{array}{l}\text { Kettle } \\
\text { River }\end{array}$ & 9 & -1.476 & -- & - & \\
\hline
\end{tabular}

(a) Value in () is the log-mean ${ }^{90} \mathrm{Sr}$ concentration. 



\section{DISCUSSION}

This section discusses factors that influence the accumulation of radionuclides in Hanford Reach fish relative to background locations, tissue concentrations, and associated doses estimates that could result from the consumption of fish.

\section{ACCUMULATION OF RADIONUCLIDES}

The evaluation of concentrations of man-made radionuclides in Hanford Reach fish indicates that most radionuclides released from Hanford operations during the plutonium production years (1944 through 1989) are no longer measurable using state-of-the-art gamma spectroscopy, or are found at very low concentrations with more sophisticated radiochemical methods. Consequently, it is difficult to demonstrate either a contribution of a radionuclide in fish attributable to Hanford Site releases or trends in fish tissue for most man-made radionuclides. These difficulties are not just analytical, but are also influenced by the complex interactions of the radionuclides between fish and the aquatic environment. These influences are evident in the high variability associated with the fish data and may be explained by the following factors:

1. the environmental chemistry of the radionuclides in the river (in this report, the discussion was restricted to ${ }^{90} \mathrm{Sr}$ and ${ }^{137} \mathrm{Cs}$ )

2. the behavior and movement of the fish species that were sampled and how that is influenced by dams

3. the impact of fallout radioactivity historically deposited in the Columbia River drainage system and its influence on tissue concentrations from background locations and in Hanford Reach fish.

Ideally, a background location should not be impacted by Hanford releases, should sustain adequate populations of fish for sampling requirements, and should be as similar to the Hanford Reach as possible with respect to water chemistry and background radionuclide concentrations in water and sediment. Estimates of Hanford impacts and more realistic dose estimates to consumers of fish can be attained when these factors are understood and quantified. It is not always possible to find sites that ideally fulfill all these criteria, and compromises were made in the selection of background locations. The primary objective in selecting a background site was not to provide a reference for tissue concentrations, but rather to provide a basis for estimating a background radiological dose to consumers. To this end, the influence of fallout was not controlled as rigorously as if the objective would have been to evaluate the incremental increase in radionuclide concentration in fish tissue.

\section{Environmental Chemistry}

Environmental chemistry of radionuclides and the influence of water chemistry on environmental fate have been the subjects of much research (reviewed by Coughtrey and Thorne 1983). I will briefly touch on the key aspects of the environmental behavior of ${ }^{90} \mathrm{Sr}$ and ${ }^{137} \mathrm{Cs}$ in freshwater aquatic systems. The aspects of environmental chemistry are important when comparing Hanford Reach fish to background locations, particularly if the background location is different from the Hanford Reach in its chemical and physical character. 
Strontium-90 is a chemical analog of calcium and behaves similarly in the environment. It is freely soluble as a divalent cation; consequently, it tends to remain dissolved, is very mobile in aquatic systems, and is prone to be accumulated by organisms that also accumulate calcium. Fish can obtain their dietary requirements for calcium by direct absorption from the water, but may also accumulate calcium from food. Consequently, the potential to accumulate ${ }^{90} \mathrm{Sr}$ is generally inversely related to the amount of calcium in the water (Vanderploeg et al. 1975). Concentrations of ${ }^{90} \mathrm{Sr}$ in fish bone, consequently, are lower in fish inhabiting hard water ecosystems compared to those in soft water systems as a result of dissolved divalent cations, principally, $\mathrm{Ca}$, but also $\mathrm{Mg}$ and, stable $\mathrm{Sr}$.

Cesium-137 is a monovalent cation that has a high affinity for adsorption to suspended material and clay. Cesium is a chemical analog of $\mathrm{K}$, and ${ }^{137} \mathrm{Cs}$ uptake and accumulation in muscle is inversely related to $\mathrm{K}$ concentration in freshwater (Vanderploeg et al. 1975). Releases of ${ }^{137} \mathrm{Cs}$ are rather quickly scavenged by suspended matter (e.g., sediment, plankton) in the river, thereby reducing the potential for direct uptake of soluble ${ }^{137} \mathrm{Cs}$ from the water column by fish. Accumulation by fish is attributed more to food chain transfer processes than direct uptake from the water. There is a greater tendency for ${ }^{137} \mathrm{Cs}$ to be sequestered in sediments where it is less available to fish. Cesium-137 associated with plankton is the first stage of food chain transfer to fish.

While extensive water quality information has been collected on the Hanford Reach and is documented in annual monitoring reports, the sites used for background locations for fish sampling have not been characterized, either in terms of concentrations of radioactivity or chemical character of the water. This limits our ability to explain observed differences in concentrations of radionuclides in fish, particularly whitefish and bass, that were collected from locations potentially dissimilar to the Hanford Reach.

\section{Fish Behavior}

Background locations were chosen to provide tissue concentrations to evaluate the potential influence of Hanford Site operations on fish. Resident fish are not restricted in their movements through the Reach and can enter the Snake River or Yakima River as well as move downstream into Lake Wallula (the McNary Dam impoundment). Dams located upstream of Hanford have fish ladders to assist the migration of fish, primarily salmonids, but also other resident species. Grand Coulee Dam is not equipped with fish ladders and represents the closest upstream barrier to fish migration. Consideration must be given to the potential for fish sampled upstream of Hanford as background fish to have previously resided in the Hanford Reach. The salmon data collected in 1988 represent migrating adults whose residence time in the Hanford Reach was unknown, but probably less than 4 months Because adult salmon do not feed when they migrate, the potential to accumulate radionuclides from food chain pathways is insignificant.

\section{$\underline{\text { Bass }}$}

Movements of bass have been documented in the Hanford Reach in radiotagging studies (Montgomery and Fickeisen 1978). Bass were collected and tagged in F Slough, White Bluffs Slough, and the Hanford Townsite Slough during the breeding season in May and June in 1977. Most radiotagged bass resided in the main channel of the river close to the sloughs after spawning. They slowly disperse downstream through the summer. All fish radiotagged in the Hanford Reach sloughs during this study remained in the Reach, with the most distant fish collected by a fisher $63 \mathrm{~km}$ ( $40 \mathrm{mi})$ downstream in Lake Walulla. 
The potential for upstream migration of bass over Priest Rapids Dam is small. Mullan et al. (1986) report that too few bass move over dams upstream of McNary to be tabulated. Bass prefer warmer water, and their distribution is limited more to the downstream reservoirs by water temperature. The Sunnyside pond was selected for background bass collection because of the large resident population of bass and its location upwind of Hanford. From this perspective, Sunnyside was a reasonable location for estimating background bass concentrations; however, it cannot directly address Hanford effects because the pond has its own separate ecosystem, levels of fallout radioactivity in the pond are not known, and the water characteristics of the pond are not known.

\section{$\underline{\text { Carp }}$}

Carp are also known to pass over dam ladders; however, their movements are more or less random. Maximum passage over Priest Rapids Dam occurred in 1966 with about 24,000 fish. Passage steadily decreased in subsequent years to less than 2000 fish in 1983 (Mullan et al. 1986). More importantly, migration over Wanapum Dam was very low, indicating that the carp collected at Vantage are most likely truly distinct from Hanford Reach populations.

The selection of Vantage as a background location balances concern for isolation from Hanford with concern for the need to provide realistic upstream conditions that are not adversely influenced by high background radioactivity.

\section{Whitefish}

Whitefish migrate seasonally upstream to eventually spawn in tributaries or the main stem of the Columbia. River. Ladder counts for Priest Rapids Dam ranged from initially 80,000 in 1963 to about 17,000 in 1983 (Mullan et al. 1986). For this reason, the distant Kettle River background location was selected because it was the closest upstream location that has a nonpassable barrier (Grand Coulee Dam) separating it from the Hanford Reach. However, precipitation in the Kettle River basin is about three to four times the level at Hanford, implying that historical fallout would also be elevated in this region. High historical fallout is the most reasonable explanation for the elevated ${ }^{90} \mathrm{Sr}$ observed in whitefish carcass collected from the Kettle River.

A significant concern in the fish monitoring program is whether the fish collected are representative of fish from the area sampled. The amount of residence time fish sampled from the Hanford Reach have spent in the area cannot be quantified. Most collections of whitefish occurred during the peak migration period from October through January. Moreover, whitefish collected from Priest Rapids and the 100-N to 100-D Areas most likely represent the same general group of fish. These fish represent the population that would be harvested by fishers and are suitable to estimate doses for fishers. The potential variations introduced by migration are less of a concern for carp and bass. For the overall evaluation of trends over the past 11 years, these perturbations may introduce additional uncertainty, but do not invalidate the data for assessing trends or Hanford effects:

\section{Radioactive Fallout}

The preceding discussion on fish movement and environmental chemistry highlights a key observation in this study. In carp and whitefish carcasses, the levels of ${ }^{90} \mathrm{Sr}$ in background samples significantly exceeded the concentrations in Hanford Reach fish from the same period. This. is not a contradiction if the environmental concentrations of ${ }^{90} \mathrm{Sr}$ in the fish's habitat were higher than for Hanford 
Reach fish. The environmental conditions and concentrations of ${ }^{90} \mathrm{Sr}$ of background fish habitat was not measured, and bioaccumulation processes cannot be quantified.

The most plausible explanation for the elevated concentrations of ${ }^{90} \mathrm{Sr}$ is historical fallout from atmospheric weapons testing in the 1950s and 1960s. Fallout levels correspond with increased precipitation, and there is a reasonable likelihood that exposure concentrations of Kettle River fish were actually greater than those of Hanford Reach fish as a result of fallout. The primary Hanford Site source of ${ }^{90} \mathrm{Sr}$ in the Columbia River during this time was the $100-\mathrm{N}$ Area springs, which discharge to the river around RM 380. However, the largest source of ${ }^{90} \mathrm{Sr}$ and ${ }^{137} \mathrm{Cs}$ in the Columbia River is watershed runoff from the river's many tributaries. There are no major tributaries to the Columbia River between the confluence of the Wenatchee River (RM 468) and the confluence of the Yakima River at RM 335; consequently, the $112 \mathrm{~km}$ (70 mi) stretch upstream from Priest Rapids Dam should be relatively consistent in its makeup of fallout radioactivity.

The influence of fallout radioactivity was evident in measurements of ${ }^{90} \mathrm{Sr}$ and ${ }^{137} \mathrm{Cs}$ in water at Priest Rapids and downstream of the Hanford Site at the Richland pumphouse (Dirkes 1994). Annual average concentrations of ${ }^{90} \mathrm{Sr}$ ranged from 0.07 to $0.29 \mathrm{pCi} / \mathrm{L}$ at the Richland pumphouse or 300 Area water sample collection locations compared to a range of 0.08 to $0.24 \mathrm{pCi} / \mathrm{L}$ at upstream $(100-\mathrm{B}$ or Vernita Bridge) sampling locations. Statistically, there was no difference between locations from 1980 to 1989, indicating that contributions from the Hanford Site are not of sufficient magnitude to produce. a demonstrable effect. In comparison, the monitored concentrations of ${ }^{90} \mathrm{Sr}$ in bass and whitefish reflect the reported discharges of ${ }^{90} \mathrm{Sr}$ over the years 1982 through 1992 (see Figure 1). Specifically, the results suggest an increase followed by a decline, as indicated in carcass data from bass and whitefish and corroborated by second-order regression models and simple regression of site releases and logtransformed median tissue concentrations. The measurements of ${ }^{137} \mathrm{Cs}$ in fish are generally too low to draw any firm conclusion on impacts from the Hanford Site in water or fish.

\section{TISSUE CONCENTRATIONS}

Carcass samples were analyzed for ${ }^{90} \mathrm{Sr}$ because carcass contains a large amount of calcified bone tissue, and ${ }^{90} \mathrm{Sr}$ is a chemical analog to calcium (Poston and Klopfer 1988). Concentrations of ${ }^{90} \mathrm{Sr}$ reported in muscle samples may, in fact, represent residual levels in fish bone that were not removed during the filleting process. The $100-\mathrm{N}$ Area springs source probably accounts for the wider range of ${ }^{90} \mathrm{Sr}$ observed in Hanford Reach fish carcasses. A few 1990 carp had relatively high concentrations of ${ }^{90} \mathrm{Sr}$ in their carcasses. These fish had clam shells (Corbicula sp.) in their stomachs. A clam shell from 100-N Area springs in 1990 had $266( \pm 20 \%) \cdot \mathrm{pCi}^{90} \mathrm{Sr} / \mathrm{g}$ (Woodruff et al. 1992); the flesh contained $0.05 \mathrm{pCi} / \mathrm{g}$ (Woodruff et al. 1991). These observations suggest a possible food chain pathway to carp; however, the extent of contamination from the 100-N Area springs is small, and the potential for carp to feed on clams residing in the area effected by the springs is also relatively small. Consequently, the potential for contamination of many fish is small, as indicated in the monitoring data.

Cesium-137 was evaluated in the muscle of bass, carp, and whitefish. Because ${ }^{137} \mathrm{Cs}$ is a chemical analog of potassium, it accumulates in muscle tissue and is a concern for potential dose to consumers of fish (Poston and Klopfer 1988). The demonstrated decreasing trend in median ${ }^{137} \mathrm{Cs}$ in bass muscle, while significant, is somewhat compromised by the high percentage of nonmeasurable concentrations. The fact that ${ }^{137} \mathrm{Cs}$ generally was not measured in fish illustrates the dilution of the Columbia River and the overall low concentrations of ${ }^{137} \mathrm{Cs}$ in seep water and permitted discharges to the river at the Hanford Site. As was noted with ${ }^{90} \mathrm{Sr}$, atmospheric fallout has contributed to elevated 
environmental concentrations of ${ }^{137} \mathrm{Cs}$, but there was no indication of elevated levels of ${ }^{137} \mathrm{Cs}$ in background fish relative to Hanford Reach fish in this study.

The significance of fish tissue concentrations lies in its potential for the radionuclides to impact human populations. Native American's or ethnic groups may harvest, cook, or prepare fish in ways that influence human exposure. For example, a diet dominated by salmon would contribute less radioactivity to radiological dose than a diet dominated by resident species because the anadramous life cycle of salmon reduces the residence time in the Columbia River and the non -feeding adults do not accumulate radioactivity via the food chain. Consumption of fish muscle is the most direct pathway to humans. Fish carcass and its associated burden of ${ }^{90} \mathrm{Sr}$ would most likely be discarded. Canning, poaching, or pickling fish, however, will soften bones so that they could be consumed without discomfort. Fish carcass could also be used for fertilizer in home gardens, which would lead to an indirect consumption pathway. The potential dose impact of fish consumption is summarized in the next section, Dose Considerations.

\section{DOSE CONSIDERATIONS}

Each year, the Hanford Site environmental monitoring report addresses the estimated dose to the maximally exposed individual (MEI). The MEI is a hypothetical person that receives the highest possible dose from all environmental pathways. In 1982, the dose resulting from the consumption of $40 \mathrm{~kg}$ of Columbia River fish in combination with other modeled river pathways (i.e., immersion in water, exposure to the shoreline) was 0.04 mrem to the whole body and 0.1 mrem to bone (Sula et al. 1983). In 1992 , the reported estimated dose to the MEI resulting from river recreation and fish consumption was 0.006 mrem (Woodruff et al. 1993). While assumptions in the dose modeling were different in 1982 compared to 1992, the overall trend in estimated doses is downward.

The DOE guideline for public exposure, which is based on the National Council on Radiation Protection and Measurements' recommendations (NCRP 1987), is 100 mrem (U.S. DOE 1990). Estimates of background radiation to humans from natural sources of radiation are approximately $300 \mathrm{mrem}$. The DOE field office is notified when a fish tissue concentration reaches a level that would result in a 1.0mrem dose to a human consumer (U.S. DOE 1991). This 1.0 -mrem dose would be attained from the consumption of $40 \mathrm{~kg}$ of fish in a year that contained either $0.18 \mathrm{pCi}{ }^{90} \mathrm{Sr} / \mathrm{g}$ fish or $0.54 \mathrm{pCi}{ }^{137} \mathrm{Cs} / \mathrm{g}$ of fish. Under an assumption that fish carcasses would be consumed, recent monitoring data suggests that estimated doses would actually be higher in background fish than those observed in some populations of Hanford Reach fish. This observation illustrates how low tissue concentrations are in some Hanford Reach fish and provides a measure of comparison for estimated doses resulting from the consumption of fish collected at background locations. Concentrations of radioactivity measured in bass, carp, and whitefish over the past 11 years do not constitute a significant radiological dose to the fish-eating public. Consumption of salmon collected from the Reach also contributes little to the estimated dose resulting from Hanford Site activities.

The DOE has established a guideline dose rate of $1.0 \mathrm{rad} / \mathrm{d}$ for aquatic life (U.S. DOE 1990). Based on a maximum carcass concentration of ${ }^{90} \mathrm{Sr}$ in carp in 1992 (Woodruff et al. 1993), the estimated dose rate was $0.01 \mathrm{mrad} / \mathrm{d}$, or 100,000 times lower than the DOE standard. In 1991, the maximum calculated dose was to a whitefish and it was $0.001 \mathrm{rad} / \mathrm{d}$ (Woodruff et al. 1992). A worst-case estimate was also prepared for carp residing around $100-\mathrm{N}$ springs that consumed clams residing in the spring area. The hypothetical maximum dose rate from internal accumulation of radioactivity from the clam under dietary equilibrium was $0.05 \mathrm{mrad} / \mathrm{d}$ (Poston and Soldat 1992). These recent examples of dose calculations indicate that present concentrations of man-made radionuclides in Hanford Reach fish do not result in notable radiological doses to these fish. For some species of background fish, where background concentrations of ${ }^{90} \mathrm{Sr}$ exceeded Hanford Reach fish concentrations, estimated doses in background would be comparable or slightly exceed estimated doses of Hanford Reach fish. 


\section{CONCLUSIONS}

This evaluation address two basic questions. What were the trends of radionuclide concentrations in fish from the Hanford Reach, and how do they relate to reported Site releases of radionuclides to the river? The second question is were concentrations of radionuclides in Hanford Reach fish different compared to fish collected from locations designated as background locations? Based on the statistical analysis of data on bass, carp, whitefish, and salmon, this report draws the following conclusions about trends and location effects.

Trends. Overall, radionuclides have decreased over the 11-year study period. Most man-made gamma-emitting radionuclides previously found in Hanford Reach fish are no longer found at measurable concentrations because of their short half-lives. Strontium- 90 and Cesium-137 are the only man-made radionuclides that were measured. The general reduction of ${ }^{90} \mathrm{Sr}$ and ${ }^{137} \mathrm{Cs}$ was punctuated with a moderate increase and subsequent decline that paralleled reported releases of ${ }^{90} \mathrm{Sr}$ to the river. The same pattern was evident for ${ }^{137} \mathrm{Cs}$ in fish but high variability in the data and very low concentrations of ${ }^{137} \mathrm{Cs}$ (less than detection levels) in fish samples weaken the statistical comparison.

Location Effects. Regression analysis of ${ }^{90} \mathrm{Sr}$ in fish carcass samples clearly demonstrates a relationship between bass and whitefish carcass concentrations and reported releases. Tissue concentrations since 1988, however, have declined to a level where they generally are comparable or in some cases less than background location samples. This conclusion is based on only 1 or 2 years of background location data for bass, carp, or whitefish, which is statistically limited and will improve with additional sample collection at background locations in the future. That background fish carcass samples contain concentrations of ${ }^{90} \mathrm{Sr}$ exceeding Hanford Reach fish concentrations illustrates the magnitude of current Hanford operations on resident fish populations.

While the ability to monitor trends in fish samples and relate them to releases is quite noteworthy; the monitored concentrations of ${ }^{90} \mathrm{Sr}$ and ${ }^{137} \mathrm{Cs}$ in fish currently are very low and posed no known risk to human consumers of Hanford Reach fish or to the fish themselves. The results of this report have value for documenting concentrations of radionuclides against which future monitoring results can be compared, particularly for clean-up and remediation activities that impact the Columbia River.

One of the purposes of monitoring fish in the Columbia River is to estimate human doses resulting from the hypothetical consumption of Hanford Reach fish. Past and continued monitoring of Hanford Reach fish assures the public that these fish are safe to eat. This assessment of concentrations of ${ }^{90} \mathrm{Sr}$ and ${ }^{137} \mathrm{Cs}$ in fish indicates that the monitoring program should be reviewed to determine the direction and level of effort needed to meet public assurance objectives and how questions regarding trends and Hanford effects can be better addressed. 



\section{REFERENCES}

Coughtrey, P. J., and M. C. Thorne. 1983. Radionuclide Distribution and Transport in Terrestrial and Aquatic Ecosystems, A Critical Review of Data. Vol. 1 of 6, A. A. Balkema, Rotterdam, Netherlands.

Cushing, C. E., D. G. Watson, A. J. Scott, and J. M. Gurtisen. 1980. Decline of Radionuclides in Columbia River Biota. PNL-3269, Pacific Northwest Laboratory, Richland, Washington.

Dauble, D. D., K. R. Price, and T. M. Poston. 1993. Radionuclide Concentration in White Sturgeon from the Columbia River. PNL-8221, Rev. 1, Pacific Northwest Laboratory, Richland, Washington.

Denham, D. H., R. L. Dirkes, R. W. Hanf, T. M. Poston, M. E. Thiede, and R. K. Woodruff. 1993. Phase I Summaries of Radionuclide Concentration Data for Vegetation, River Water, Drinking Water and Fish. PNWD-2145 HEDR. Battelle Pacific Northwest Laboratories, Richland, Washington.

Dirkes, R. L. 1990. 1988 Hanford Riverbank Springs Characterization Report. PNL-7500, Pacific Northwest Laboratory, Richland, Washington.

Dirkes, R. L. 1994. Summary of Radiological Monitoring of Columbia River Water Along the Hanford Reach, 1980 to 1989. PNL-9223, Pacific Northwest Laboratory, Richland, Washington.

Eberhardt, L. E., and R. O. Gilbert. 1980. "Statistics and Sampling in Transuranic Studies." In Transuranic Elements in the Environment, W. C. Hanson, ed., pp. 173-186. National Technical Information Center, Springfield, Virginia.

Eberhardt, L. E., L. L. Cadwell, K. R. Price, and D. W. Carlile. 1989. Trends in Radionuclide Concentrations for Selected Wildlife and Food Products Near the Hanford Site From 1971 to 1988. PNL-6992, Pacific Northwest Laboratory, Richland, Washington.

Foster, R. F., and Environmental Studies and Evaluation Staff. 1965. Evaluation of Radiological Conditions in the Vicinity of Hanford for 1964. AEC Research and Development Report BNWL 90, Pacific Northwest Laboratory, Richland, Washington.

Foster, R. F., and Environmental Studies and Evaluation Staff. 1966. Evaluation of Radiological Conditions in the Vicinity of Hanford for 1965. BNWL-316, Pacific Northwest Laboratory, Richland, Washington.

Foster, R. F., and Environmental Studies and Evaluation Staff. 1967. Evaluation of Radiological Conditions in the Vicinity of Hanford for 1966. BNWL-439, Pacific Northwest Laboratory, Richland, Washington.

Heeb, C. M., and D. J. Bates. 1994. Radionuclide Releases to the Columbia River from Hanford Operations, 1944-1971. PNWD-2223 HEDR, Battelle Pacific Northwest Laboratories, Richland, Washington. 
Jaquish, R. E., and R. W. Bryce (eds). 1989. Hanford Site Environmental Report for Calendar Year 1988. PNL-7346, Pacific Northwest Laboratory, Richland, Washington.

Jaquish, R. E., and R. W. Bryce (eds). 1990. Hanford Site Environmental Report for Calendar Year 1989. PNL-6825, Pacific Northwest Laboratory, Richland, Washington.

McCormack, W. D., and J.M.V. Carlile. 1984. Investigation of Ground-Water Seepage from the Hanford Shoreline of the Columbia River. PNL-5289, Pacific Northwest Laboratory, Richland, Washington.

Montgomery, J. C., and D. H. Fickeisen. 1978. Spawning and Movements of Smallmouth Bass (Micropterus dolomieui) in the Mid-Columbia River. . PNL-2785, Pacific Northwest Laboratory, Richland, Washington.

Mullan, J. W., M. B. Dell, S. G. Hays, and J. A. McGee. 1986. Some Factors Affecting Fish Production in the Mid-Columbia River 1934 1983. FRU/FRO-86-15, U.S. Fish and Wildlife Service, Fisheries Assistance Office, Leavenworth, Washington.

National Council on Radiation Protection and Measurements (NCRP). 1979. Tritium in the Environment. NCRP Report No. 62, National Council on Radiation Protection and Measurements, Bethesda, Maryland.

National Council on Radiation Protection and Measurements (NCRP). 1987. Recommendations on Limits for Exposure to lonizing Radiation. NCRP Report No. 91, National Council on Radiation Protection and Measurements, Bethesda, Maryland.

Nielsen, L. A., and D. L. Johnson (eds.). 1983. Fisheries Techniques. American Fisheries Society, Bethesda, Maryland.

Poston, T. M., and D. C. Klopfer. 1988. "Concentration Factors Used in the Assessment of Radiation Dose to Consumers of Fish: A Review of 27 Radionuclides." Health Phys. 55:751-766.

Poston, T. M., and J. K. Soldat. 1992. Scoping Assessment of Radiological Doses to Aquatic Organisms and Wildlife - N Springs. PNL-8360, Pacific Northwest Laboratory, Richland, Washington.

Soldat, J. K. 1970. "A Statistical Study of the Habits of Fishermen Utilizing the Columbia River below Hanford." In Environmental Surveillance in the Vicinity of Nuclear Facilities, W. C. Reinig, ed., pp. 302-308. Charles C. Thomas, Springfield, Illinois.

Sokal, R. R., and F. J. Rohlf. 1981. Biometry. Second Edition, W. H. Freeman and Company, New York.

Sula, M. J., J.M.V. Carlile, K. R. Price, and W. D. McCormack. 1983. Environmental Surveillance at the Hanford Site for CY 1982. PNL-4657, Pacific Northwest Laboratory, Richland, Washington.

U.S. Department of Energy (U.S. DOE). 1990. "Radiation Protection of the Public and the Environment." DOE Order 5400.5. 
U.S. Department of Energy (U.S. DOE). 1991. Environmental Monitoring Plan. DOE/RL 91-50, U.S. Department of Energy, Richland, Washington.

Vanderploeg, H. A., D. C. Parzyck, W. H. Wilcox, J. R. Kerchner, and S. V. Kaye. 1975.

Bioaccumulation Factors for Radionuclides in Freshwater Biota. ORNL-5002, Oak Ridge National Laboratory, Oak Ridge, Tennessee.

Watson, D. G., C. E. Cushing, C. C. Coutant, and W. L. Templeton. 1970. Radioecological Studies in the Columbia River. Part I and II. BNWL-1377, Pacific Northwest Laboratory, Richland, Washington.

Walters, W. H., R. L. Dirkes, and B. A. Napier. 1992. Literature and Data Review for the Surface-water Pathway: Columbia River and Adjacent Coastal Areas. PNWL-2034 HEDR, Battelle Pacific Northwest Laboratories, Richland, Washington.

Woodruff, R. K., R. W. Hanf, M. G. Hefty, and R. E. Lundgren (eds.). 1991. Hanford Site Environmental Report for Calendar Year 1990. PNL-7930, Pacific Northwest Laboratory, Richland, Washington.

Woodruff, R. K., R. W. Hanf, and R. E. Lundgren (eds.). 1992. Hanford Site Environmental Report for Calendar Year 1991. PNL-8148, Pacific Northwest Laboratory, Richland, Washington.

Woodruff, R. K., R. W. Hanf, and R. E. Lundgren (eds.). 1993. Hanford Site Environmental Report for Calendar Year 1992. PNL-8682, Pacific Northwest Laboratory, Richland, Washington. 
APPENDIX A

RADIONUCLIDE CONCENTRATIONS IN FISH 


\section{APPENDIX A}

\section{RADIONUCLIDE CONCENTRATIONS IN FISH}

This appendix contains data entries extracted from the Surface Environmental Surveillance Project data base. The data have been grouped by species into four tables. Each table is organized by sample location, tissue type (either carcass or muscle), radionuclide, sample collection date, the reported concentrations in $\mathrm{pCi} / \mathrm{g}$ wet-weight, the two-sigma counting error, and the two-sigma propagated analytical error. For radionuclides quantified by gamma spectroscopy, the two-sigma counting error and the two-sigma propagated analytical error are essentially the same. Additionally, the two-sigma propagated analytical error was not entered into the data base in 1982 and 1983 and has not been reported for those years. An asterisk (*) in the right-hand column of each entry indicates that the associated propagated or counting error term exceeds the corresponding concentration, essentially indicating that the radionuclide was not detected. 
Table A.1. Radionuclide Concentrations in Bass, 1983-1992 (continued)

\begin{tabular}{|c|c|c|c|c|c|c|}
\hline Location & Tissue & Radionuclide & $\begin{array}{c}\text { Date } \\
(\mathrm{M} / \mathrm{D} / \mathrm{Y})\end{array}$ & $\begin{array}{c}\text { Conicentration } \\
\text { (pCi/g wet) }\end{array}$ & $\begin{array}{l}\text { Counting } \\
\text { Error } \\
\text { (pCi/g wet) }\end{array}$ & $\begin{array}{c}\text { Propagated } \\
\text { Analytical } \\
\text { Error } \\
\text { (pCi/g wet) }\end{array}$ \\
\hline$\overline{\text { F Slough }}$ & Carcass & Sr-90 & $6 / 9 / 83$ & $3.65 \mathrm{E}-04$ & $8.30 \mathrm{E}-04$ & Not reported \\
\hline F Slough & Carcass & Sr-90 & $6 / 9 / 83$ & $3.79 \mathrm{E}-03$ & $1.18 \mathrm{E}-03$ & Not reported \\
\hline F Slough & Carcass & Sr-90 & $6 / 9 / 83$ & $8.47 \mathrm{E}-03$ & $1.53 \mathrm{E}-03$ & Not reported \\
\hline F Slough & Carcass & Sr-90 & $6 / 9 / 83$ & $1.47 \mathrm{E}-02$ & $1.73 \mathrm{E}-03$ & Not reported \\
\hline F Slough & Carcass & Sr-90 & $6 / 9 / 83$ & $3.36 \mathrm{E}-02$ & $2.54 \mathrm{E}-03$ & Not reported \\
\hline F Slough & Carcass & $\mathrm{Sr}-90$ & $5 / 18 / 84$ & $2.49 \mathrm{E}-02$ & $5.23 \mathrm{E}-03$ & $8.23 \mathrm{E}-03$ \\
\hline F Slough & Carcass & $\mathrm{Sr}-90$ & $5 / 18 / 84$ & 5.79E-02 & $6.23 \mathrm{E}-03$ & 1.20E-02 \\
\hline F Slough & Carcass & $\mathrm{Sr}-90$ & $5 / 18 / 84$ & $5.91 \mathrm{E}-02$ & $6.70 \mathrm{E}-03$ & $1.26 \mathrm{E}-02$ \\
\hline F Slough & Carcass & $\mathrm{Sr}-90$ & $5 / 18 / 84$ & $6.47 \mathrm{E}-02$ & 8.62E-03 & $1.44 \mathrm{E}-02$ \\
\hline F Slough & Carcass & Sr-90 & $5 / 18 / 84$ & $7.75 \mathrm{E}-02$ & 8.40E-03 & $1.63 \mathrm{E}-02$ \\
\hline F Slough & Carcass & Sr-90 & $5 / 24 / 85$ & $2.99 \mathrm{E}-02$ & $2.53 \mathrm{E}-03$ & 6.31E-03 \\
\hline F Slough & Carcass & Sr-90 & $5 / 24 / 85$ & $4.67 \mathrm{E}-02$ & $4.12 \mathrm{E}-03$ & $9.93 \mathrm{E}-03$ \\
\hline F Slough & Carcass & $\mathrm{Sr}-90$ & $5 / 24 / 85$ & $5.78 \mathrm{E}-02$ & $4.48 \mathrm{E}-03$ & $1.20 \mathrm{E}-02$ \\
\hline F Slough & Carcass & Sr-90 & $5 / 24 / 85$ & $6.23 \mathrm{E}-02$ & $1.24 \mathrm{E}-02$ & $1.75 \mathrm{E}-02$ \\
\hline F Slough & Carcass & Sr-90 & $5 / 31 / 85$ & 2.42E-01 & $2.32 \mathrm{E}-02$ & 5.23E-02 \\
\hline F Slough & Carcass & $\mathrm{Sr}-90$ & $5 / 16 / 86$ & 1.07E-02 & $4.00 \mathrm{E}-03$ & $4.45 \mathrm{E}-03$ \\
\hline F Slough & Carcass & $\mathrm{Sr}-90$ & $5 / 16 / 86$ & $1.39 \mathrm{E}-02$ & 4.32E-03 & 4.99E-03 \\
\hline F Slough & Carcass & $\mathrm{Sr}-90$ & $5 / 16 / 86$ & $1.76 \mathrm{E}-02$ & 4.77E-03 & 5.70E-03 \\
\hline F Slough & Carcass & $\mathrm{Sr}-90$ & $5 / 16 / 86$ & $5.03 E-02$ & $9.71 \mathrm{E}-03$ & $1.33 \mathrm{E}-02$ \\
\hline F Slough & Carcass & Sr-90 & $5 / 29 / 86$ & $5.20 \mathrm{E}-01$ & $2.54 \mathrm{E}-02$ & $9.94 \mathrm{E}-02$ \\
\hline F Slough & Carcass & Sr-90 & $5 / 6 / 87$ & $6.58 \mathrm{E}-02$ & $3.11 \mathrm{E}-02$ & $3.54 \mathrm{E}-02$ \\
\hline F Slough & Carcass & Sr-90 & $5 / 11 / 87$ & $5.00 \mathrm{E}-02$ & 7.69E-03 & $1.47 \mathrm{E}-02$ \\
\hline F Slough & Carcass & $\mathrm{Sr}-90$ & $5 / 11 / 87$ & 5.99E-02 & $9.91 \mathrm{E}-03$ & $1.80 \mathrm{E}-02$ \\
\hline F Slough & Carcass & Sr-90 & $5 / 21 / 87$ & $2.75 \mathrm{E}-02$ & $6.14 \mathrm{E}-03$ & 9.39E-03 \\
\hline F Slough & Carcass & Sr-90 & $5 / 21 / 87$ & $4.06 \mathrm{E}-02$ & $7.11 \mathrm{E}-03$ & $1.25 \mathrm{E}-02$ \\
\hline F Slough & Carcass & Sr-90 & $5 / 10 / 88$ & $5.34 \mathrm{E}-02$ & $5.95 \mathrm{E}-03$ & $1.14 \mathrm{E}-02$ \\
\hline F Slough & Carcass & Sr-90 & $5 / 27 / 88$ & $2.11 \mathrm{E}-02$ & $4.76 \mathrm{E}-03$ & $6.32 \mathrm{E}-03$ \\
\hline F Slough & Carcass & Sr-90 & $5 / 27 / 88$ & $2.71 E-02$ & $5.94 \mathrm{E}-03$ & $7.88 \mathrm{E}-03$ \\
\hline F Slough & Carcass & Sr-90 & $6 / 2 / 88$ & $4.08 \mathrm{E}-02$ & 5.77E-03 & $9.54 \mathrm{E}-03$ \\
\hline F Slough & Carcass & Sr-90 & $6 / 2 / 88$ & $5.88 \mathrm{E}-02$ & $7.74 \mathrm{E}-03$ & $1.33 \mathrm{E}-02$ \\
\hline F Slough & Carcass & Sr-90 & $4 / 25 / 89$ & $2.36 \mathrm{E}-02$ & $2.69 \mathrm{E}-03$ & $5.49 \mathrm{E}-03$ \\
\hline F Slough & Carcass & Sr-90 & $4 / 26 / 89$ & 4.55E-02 & $3.94 \mathrm{E}-03$ & $9.51 \mathrm{E}-03$ \\
\hline F Slough & Carcass & Sr-90 & $4 / 27 / 89$ & $4.45 \mathrm{E}-02$ & $3.53 E-03$ & $1.17 \mathrm{E}-02$ \\
\hline F Slough & Carcass & Sr-90 & $.5 / 1 / 89$ & $3.04 \mathrm{E}-02$ & 3.38E-03 & 8.61E-03 \\
\hline F Slough & Carcass & Sr-90 & $5 / 3 / 89$ & $6.55 \mathrm{E}-02$ & $5.63 \mathrm{E}-03$ & $1.67 \mathrm{E}-02$ \\
\hline F Slough & Carcass & Sr-90 & $5 / 17 / 90$ & $2.86 \mathrm{E}-02$ & $4.08 \mathrm{E}-03$ & $6.80 \mathrm{E}-03$ \\
\hline F Slough & Carcass & Sr-90 & $5 / 18 / 90$ & $1.84 \mathrm{E}-02$ & $4.24 \mathrm{E}-03$ & $5.60 \mathrm{E}-03$ \\
\hline F Slough & Carcass & Sr-90 & $5 / 18 / 90$ & $3.86 \mathrm{E}-02$ & $6.46 \mathrm{E}-03$ & $9.78 \mathrm{E}-03$ \\
\hline F Slough & Carcass & Sr-90 & $5 / 20 / 90$ & $2.19 \mathrm{E}-02$ & $3.32 \mathrm{E}-03$ & $5.28 \mathrm{E}-03$ \\
\hline F Slough & Carcass & Sr-90 & $7 / 5 / 90$ & $3.70 \mathrm{E}-02$ & $6.38 \mathrm{E}-03$ & $9.24 \mathrm{E}-03$ \\
\hline F Slough & Carcass & Sr-90 & $5 / 20 / 92$ & $6.16 \mathrm{E}-03$ & 2.93E-03 & $3.31 E-03$ \\
\hline F Slough & Carcass & Sr-90 & $5 / 20 / 92$ & $1.79 \mathrm{E}-02$ & $3.51 \mathrm{E}-03$ & $5.34 \mathrm{E}-03$ \\
\hline F Slough & Carcass & Sr-90 & $5 / 20 / 92$ & $2.59 \mathrm{E}-02$ & $4.26 \mathrm{E}-03$ & $7.06 \mathrm{E}-03$ \\
\hline
\end{tabular}

- indicates the analytical error exceeds the result (counting error is used when the analytical error is not reported) 
Table A.1. Radionuclide Concentrations in Bass, 1983-1992 (continued)

\begin{tabular}{|c|c|c|c|c|c|c|}
\hline Location & Tissue & Radionuclide & $\begin{array}{c}\text { Date } \\
(\mathrm{M} / \mathrm{D} / \mathrm{Y})\end{array}$ & $\begin{array}{c}\text { Concentration } \\
\text { (pCi/g wet) }\end{array}$ & $\begin{array}{l}\text { Counting } \\
\text { Error } \\
\text { (pCi/g wet) }\end{array}$ & $\begin{array}{l}\text { Propagated } \\
\text { Analytical } \\
\text { Error } \\
\text { (pCi/g wet) }\end{array}$ \\
\hline F Slough & Carcass & $\mathrm{Sr}-90$ & $5 / 20 / 92$ & $2.91 \mathrm{E}-02$ & $4.32 \mathrm{E}-03$ & $7.50 \mathrm{E}-03$ \\
\hline F Slough & Carcass & Sr-90 & $5 / 20 / 92$ & 2.99E-02 & 4.52E-03 & 7.91E-03 \\
\hline F Slough & Muscle & Co- 60 & $6 / 9 / 83$ & $-1.05 E-02$ & $2.34 \mathrm{E}-02$ & Not reported \\
\hline F Ślough & 'Muscle & Co-60 & $6 / 9 / 83$ & $2.48 \mathrm{E}-03$ & $2.85 \mathrm{E}-02$ & Not reported \\
\hline F Slough & Muscle & Co-60 & $6 / 9 / 83$ & $1.53 \mathrm{E}-02$ & $3.09 \mathrm{E}-02$ & Not reported \\
\hline F Slough & Muscle & $\mathrm{Co}-60$ & $6 / 9 / 83$ & 2.77E-02 & 2.08E-02 & Not reported \\
\hline F Slough & Muscle & Co-60 & $6 / 9 / 83$ & $3.26 \mathrm{E}-02$ & $2.98 \mathrm{E}-02$ & Not reported \\
\hline F Slough & Muscle & $\mathrm{Co}-60$ & $5 / 18 / 84$ & $-1.15 E-02$ & $1.23 E-02$ & 1.23E-02 \\
\hline F Slough & Muscle & Co-60 & $5 / 18 / 84$ & $-4.53 E-03$ & $1.67 \mathrm{E}-02$ & Not reported \\
\hline F Slough & Muscle & Co-60 & $5 / 18 / 84$ & $9.05 \mathrm{E}-03$ & $1.08 \mathrm{E}-02$ & Not reported \\
\hline F Slough & Muscle & $\mathrm{Co}-60$ & $5 / 18 / 84$ & $1.11 E-02$ & $1.02 \mathrm{E}-02$ & Not reported \\
\hline F Slough & Muscle & Co-60 & $5 / 18 / 84$ & $1.69 \mathrm{E}-02$ & $1.44 \mathrm{E}-02$ & Not reported \\
\hline F Slough & Muscle & $\mathrm{Co}-60$ & $5 / 24 / 85$ & $-5.68 \mathrm{E}-03$ & 1.93E-02 & 1.93E-02 \\
\hline F Slough & Muscle & Co-60 & $5 / 24 / 85$ & $-3.27 E-03$ & $3.25 \mathrm{E}-02$ & $3.25 \mathrm{E}-02$ \\
\hline F Slough & Muscle & Co-60 & $5 / 24 / 85$ & $1.79 \mathrm{E}-03$ & $1.86 \mathrm{E}-02$ & $1.86 \mathrm{E}-02$ \\
\hline F Slough & Muscle & Co-60 & $5 / 24 / 85$ & $4.05 \mathrm{E}-03$ & $2.14 \mathrm{E}-02$ & $2.14 \mathrm{E}-02$ \\
\hline F Slough & Muscle & Co-60 & $5 / 31 / 85$ & $-1.73 \mathrm{E}-02$ & $3.79 E-02$ & $3.79 \mathrm{E}-02$ \\
\hline F Slough & Muscle & $\mathrm{Co}-60$ & $5 / 16 / 86$ & $-1.06 \mathrm{E}-02$ & $2.04 \mathrm{E}-02$ & $2.04 \mathrm{E}-02$ \\
\hline F Slough & Muscle & Co-60 & $5 / 16 / 86$ & $-5.64 \mathrm{E}-03$ & 7.93E-03 & 7.95E-03 \\
\hline F Slough & Muscle & $\mathrm{Co}-60$ & $5 / 16 / 86$ & $5.72 \mathrm{E}-03$ & $5.28 \mathrm{E}-03$ & 5.31E-03 \\
\hline F Slough & Muscle & $\mathrm{Co}-60$ & $5 / 16 / 86$ & 1.11E-02 & 6.73E-03 & $6.82 \mathrm{E}-03$ \\
\hline F Slough & Muscle & Co-60 & $5 / 29 / 86$ & $7.73 E-03$ & $1.35 \mathrm{E}-02$ & $1.36 \mathrm{E}-02$ \\
\hline F Slough & Muscle & $\mathrm{Co}-60$ & $5 / 6 / 87$ & $-1.28 \mathrm{E}-02$ & $3.20 \mathrm{E}-02$ & $3.20 \mathrm{E}-02$ \\
\hline F Slough & Muscle & Co-60 & $5 / 11 / 87$ & $-1.22 \mathrm{E}-02$ & $3.05 \mathrm{E}-02$ & $3.05 E-02$ \\
\hline F Slough & Muscle & $\mathrm{Co}-60$ & $5 / 11 / 87$ & $1.27 \mathrm{E}-02$ & $1.53 \mathrm{E}-02$ & $1.54 \mathrm{E}-02$ \\
\hline F Slough & Muscle & Co-60 & $5 / 21 / 87$ & 3.32E-03 & $1.76 \mathrm{E}-02$ & $1.76 \mathrm{E}-02$ \\
\hline F Slough & Muscle & $\mathrm{Co}-60$ & $5 / 21 / 87$ & $1.74 \mathrm{E}-02$ & $1.74 \mathrm{E}-02$ & $1.75 \mathrm{E}-02$ \\
\hline F Slough & Muscle & Co-60 & $5 / 10 / 88$ & 4.73E-02 & $3: 32 \mathrm{E}-02$ & $3.36 \mathrm{E}-02$ \\
\hline F Slough & Muscle & $\mathrm{Co}-60$ & $5 / 27 / 88$ & $-2.74 \mathrm{E}-03$ & $2.12 \mathrm{E}-02$ & 2.12E-02 \\
\hline F Slough & Muscle & Co-60 & $5 / 27 / 88$ & $1.34 \mathrm{E}-02$ & $4.65 \mathrm{E}-02$ & $4.65 \mathrm{E}-02$ \\
\hline F Slough & Muscle & $\mathrm{Co}-60$ & $6 / 2 / 88$ & $-1.95 \mathrm{E}-02$ & $3.41 E-02$ & $3.42 \mathrm{E}-02$ \\
\hline F Slough & Muscle & Co-60 & $6 / 2 / 88$ & 4.48E-03 & $3.24 \mathrm{E}-02$ & $3.24 \mathrm{E}-02$ \\
\hline F Slough & Muscle & Co-60 & $4 / 25 / 89$ & $-3.47 \mathrm{E}-03$ & $1.90 \mathrm{E}-02$ & $1.90 \mathrm{E}-02$ \\
\hline F Slough & Muscle & Co-60 & $4 / 26 / 89$ & $-9.77 \mathrm{E}-04$ & $1.82 \mathrm{E}-02$ & $1.82 \mathrm{E}-02$ \\
\hline F Slough & Muscle & $\mathrm{Co}-60$ & $4 / 27 / 89$ & $-3.00 \mathrm{E}-03$ & $1.47 \mathrm{E}-02$ & $1.47 \mathrm{E}-02$ \\
\hline F Slough & Muscle & Co-60 & $5 / 1 / 89$ & $-7.65 \mathrm{E}-03$ & $2.42 \mathrm{E}-02$ & $2.42 \mathrm{E}-02$ \\
\hline F Slough & Muscle & Co-60 & $5 / 3 / 89$ & $9.57 \mathrm{E}-03$ & $1.64 \mathrm{E}-02$ & $1.64 \mathrm{E}-02$ \\
\hline F Slough & Muscle & Co-60 & $5 / 17 / 90$ & $-2.40 \mathrm{E}-02$ & $4.60 \mathrm{E}-02$ & 4.61E-02 \\
\hline F Slough & Muscle & Co- 60 & $5 / 18 / 90$ & $-8.22 E-02$ & $6.24 \mathrm{E}-02$ & $6.30 \mathrm{E}-02$ \\
\hline F Slough & Muscle & $\mathrm{Co}-60$ & $5 / 18 / 90$ & $-6.26 E-02$ & 4.51E-02 & $4.55 E-02$ \\
\hline F Slough & Muscle & Co-60 & $5 / 20 / 90$ & $2.76 \mathrm{E}-03$ & $3.07 \mathrm{E}-02$ & $3.07 E-02$ \\
\hline F Slough & Muscle & Co-60 & $7 / 5 / 90$ & $-3.04 \mathrm{E}-02$ & $5.68 \mathrm{E}-02$ & $5.69 \mathrm{E}-02$ \\
\hline F Slough & Muscle & Co-60 & $5 / 20 / 92$ & $-4.15 E-02$ & $3.26 \mathrm{E}-02$ & $3.29 \mathrm{E}-02$ \\
\hline
\end{tabular}

* indicates the analytical error exceeds the result (counting error is used when the analytical error is not reported) 
Table A.1. Radionuclide Concentrations in Bass, 1983-1992 (continued)

\begin{tabular}{|c|c|c|c|c|c|c|}
\hline Location & Tissue & Radionuclide & $\begin{array}{c}\text { Date } \\
(\mathrm{M} / \mathrm{D} / \mathrm{Y})\end{array}$ & $\begin{array}{l}\text { Concentration } \\
\text { (pCi/g wet) }\end{array}$ & $\begin{array}{l}\text { Counting } \\
\text { Error } \\
\text { (pCi/g wet) }\end{array}$ & $\begin{array}{l}\text { Propagated } \\
\text { Analytical } \\
\text { Error } \\
\text { (pCi/g wet) }\end{array}$ \\
\hline$\overline{\text { F Slough }}$ & $\overline{\text { Muscle }}$ & Co-60 & $5 / 20 / 92$ & $-3.34 \mathrm{E}-03$ & $2.30 \mathrm{E}-02$ & $2.30 \mathrm{E}-02$ \\
\hline F Slough & Muscle & Co-60 & $5 / 20 / 92$ & $-2.55 \mathrm{E}-03$ & $4.18 \mathrm{E}-02$ & $4.18 \mathrm{E}-02$ \\
\hline F Slough & Muscle & $\mathrm{Co}-60$ & $5 / 20 / 92$ & $3.94 \mathrm{E}-03$ & $2.49 \mathrm{E}-02$ & $2.49 \mathrm{E}-02$ \\
\hline F Slough & Muscle & Co-60 & $5 / 20 / 92$ & 8.25E-03 & $2.62 \mathrm{E}-02$ & 2.62E-02 \\
\hline F Slough & Muscle & Cs -137 & $6 / 9 / 83$ & $1.75 \mathrm{E}-04$ & 2.54E-02. & Not reported \\
\hline F Slough & Muscle & Cs-137 & $6 / 9 / 83$ & $7.16 \mathrm{E}-03$ & $2.39 \mathrm{E}-02$ & Not reported \\
\hline F Slough & Muscle & Cs-137 & $6 / 9 / 83$ & $5.91 \mathrm{E}-02$ & $1.86 \mathrm{E}-02$ & Not reported \\
\hline F Slough & Muscle & Cs- 137 & $6 / 9 / 83$ & $1.06 \mathrm{E}-01$ & $2.11 \mathrm{E}-02$ & Not reported \\
\hline F Slough & Muscle & Cs- 137 & $6 / 9 / 83$ & $1.60 \mathrm{E}-01$ & $2.54 \mathrm{E}-02$ & Not reported \\
\hline F Slough & Muscle & Cs- 137 & $5 / 18 / 84$ & $3.78 \mathrm{E}-02$ & $1.45 \mathrm{E}-02$ & Not reported \\
\hline F Slough & Muscle & Cs-137 & $5 / 18 / 84$ & 3.92E-02 & $1.54 \mathrm{E}-02$ & Not reported \\
\hline F Slough & Muscle & Cs- 137 & $5 / 18 / 84$ & $5.18 \mathrm{E}-02$ & $1.24 \mathrm{E}-02$ & Not reported \\
\hline F Slough & Muscle & Cs- 137 & $5 / 18 / 84$ & $6.41 E-02$ & $1.43 \mathrm{E}-02$ & $1.48 \mathrm{E}-02$ \\
\hline F Slough & Muscle & Cs-137 & $5 / 18 / 84$ & $9.69 \mathrm{E}-02$ & $1.83 \mathrm{E}-02$ & Not reported \\
\hline F Slough & Muscle & Cs-137 & $5 / 24 / 85$ & $-6.77 E-04$ & $3.70 \mathrm{E}-02$ & $3.70 \mathrm{E}-02$ \\
\hline F Slough & Muscle & Cs- 137 & $5 / 24 / 85$ & $2.52 \mathrm{E}-02$ & 2.23E-02 & $2.23 \mathrm{E}-02$ \\
\hline F Slough & Muscle & Cs- 137 & $5 / 24 / 85$ & $5.01 \mathrm{E}-02$ & $3.17 \mathrm{E}-02$ & $3.18 \mathrm{E}-02$ \\
\hline F Slough & Muscle & Cs- 137 & $5 / 24 / 85$ & $6.79 \mathrm{E}-02$ & $2.36 \mathrm{E}-02$ & 2.39E-02 \\
\hline F Slough & Muscle & Cs- 137 & $5 / 31 / 85$ & $2.99 \mathrm{E}-02$ & 4.12E-02 & $4.12 \mathrm{E}-02$ \\
\hline F Slough & Muscle & Cs- 137 & $5 / 16 / 86$ & 2.37E-02 & 8.51E-03 & $8.83 \mathrm{E}-03$ \\
\hline F Slough & Muscle & Cs- 137 & $5 / 16 / 86$ & $2.61 \mathrm{E}-02$ & $1.07 \mathrm{E}-02$ & $1.10 \mathrm{E}-02$ \\
\hline F Slough & Muscle & Cs-137 & $5 / 16 / 86$ & $3.27 \mathrm{E}-02$ & 2.12E-02 & $2.15 \mathrm{E}-02$ \\
\hline F Slough & Muscle & Cs- 137 & $5 / 16 / 86$ & 4.52E-02 & $1.07 \mathrm{E}-02$ & $1.16 \mathrm{E}-02$ \\
\hline F Slough & Muscle & Cs- 137 & $5 / 29 / 86$ & $1.75 \mathrm{E}-02$ & $2.05 \mathrm{E}-02$ & $2.06 \mathrm{E}-02$ \\
\hline F Slough & Muscle & Cs-137 & $5 / 6 / 87$ & $5.50 \mathrm{E}-02$ & $3.61 \mathrm{E}-02$ & $3.65 \mathrm{E}-02$ \\
\hline F Slough & Muscle & Cs-137 & $5 / 11 / 87$ & $3.65 \mathrm{E}-02$ & $2.78 \mathrm{E}-02$ & $2.81 \mathrm{E}-02$ \\
\hline F Slough & Muscle & Cs-137 & $5 / 11 / 87$ & $5.93 \mathrm{E}-02$ & $2.43 E-02$ & $2.50 \mathrm{E}-02$ \\
\hline F Slough & Muscle & Cs-137 & $5 / 21 / 87$ & $2.58 \mathrm{E}-02$ & $2.06 \mathrm{E}-02$ & $2.08 \mathrm{E}-02$ \\
\hline F Slough & Muscle & Cs- 137 & $5 / 21 / 87$ & $6.58 \mathrm{E}-02$ & $2.58 \mathrm{E}-02$ & $2.66 \mathrm{E}-02$ \\
\hline F Slough & Muscle & Cs- 137 & $5 / 10 / 88$ & 8.91E-02 & $4.56 \mathrm{E}-02$ & $4.65 \mathrm{E}-02$ \\
\hline F Slough & Muscle & Cs- 137 & $5 / 27 / 88$ & $2.81 E-02$ & $2.33 E-02$ & $2.34 \mathrm{E}-02$ \\
\hline F Slough & Muscle & Cs- 137 & $5 / 27 / 88$ & $3.21 \mathrm{E}-02$ & 4.19E-02 & $4.20 \mathrm{E}-02$ \\
\hline F Slough & Muscle & Cs- 137 & $6 / 2 / 88$ & $5.23 \mathrm{E}-02$ & $2.77 \mathrm{E}-02$ & $2.82 \mathrm{E}-02$ \\
\hline F Slough & Muscle & Cs- 137 & $6 / 2 / 88$ & $6.49 \mathrm{E}-02$ & $2.98 \mathrm{E}-02$ & $3.05 \mathrm{E}-02$ \\
\hline F Slough & Muscle & $\mathrm{Cs}-137$ & $4 / 25 / 89$ & $5.00 \mathrm{E}-02$ & $2.34 E-02$ & $2.39 E-02$ \\
\hline F Slough & Muscle & Cs-137 & $4 / 26 / 89$ & $2.58 \mathrm{E}-02$ & 1.80E-02 & $1.82 \mathrm{E}-02$ \\
\hline F Slough & Muscle & Cs- 137 & $4 / 27 / 89$ & $2.33 \mathrm{E}-02$ & $1.67 \mathrm{E}-02$ & $1.69 \mathrm{E}-02$ \\
\hline F Slough & Muscle & Cs-137 & $5 / 1 / 89$ & $3.56 \mathrm{E}-02$ & $1.88 \mathrm{E}-02$ & $1.92 \mathrm{E}-02$ \\
\hline F Slough & Muscle & Cs-137 & $5 / 3 / 89$ & $2.59 \mathrm{E}-02$ & $1.65 \mathrm{E}-02$ & $1.67 \mathrm{E}-02$ \\
\hline F Slough & Muscle & Cs-137 & $5 / 17 / 90$ & $6.42 \mathrm{E}-02$ & $3.64 \mathrm{E}-02$ & $3.70 \mathrm{E}-02$ \\
\hline F Slough & Muscle & Cs-137 & $5 / 18 / 90$ & $1.33 \mathrm{E}-02$ & $5.21 \mathrm{E}-02$ & $5.21 E-02$ \\
\hline F Slough & Muscle & Cs-137 & $5 / 18 / 90$ & $2.88 \mathrm{E}-02$ & $4.20 \mathrm{E}-02$ & $4.21 \mathrm{E}-02$ \\
\hline F Slough & Muscle & Cs-137 & $5 / 20 / 90$ & $3.85 \mathrm{E}-03$ & $3.67 \mathrm{E}-02$ & $3.67 \mathrm{E}-02$ \\
\hline
\end{tabular}

- indicates the analytical error exceeds the result (counting error is used when the analytical error is not reported) 
Table A.1. Radionuclide Concentrations in Bass, 1983-1992 (continued)

\begin{tabular}{|c|c|c|c|c|c|c|c|}
\hline Location & Tissue & Radionuclide & $\begin{array}{c}\text { Date } \\
(\mathrm{M} / \mathrm{D} / \mathrm{Y})\end{array}$ & $\begin{array}{c}\text { Concentration } \\
\text { (pCi/g wet) }\end{array}$ & $\begin{array}{l}\text { Counting } \\
\text { Error } \\
\text { (pCi/g wet) }\end{array}$ & $\begin{array}{l}\text { Propagated } \\
\text { Analytical } \\
\text { Error } \\
\text { (pCi/g wet) }\end{array}$ & \\
\hline F Slough & $\overline{\text { Muscle }}$ & Cs-137 & $7 / 5 / 90$ & $-1.56 \mathrm{E}-02$ & $4.46 \mathrm{E}-02$ & $4.47 \mathrm{E}-02$ & $*$ \\
\hline F Slough & Muscle & Cs-137 & $5 / 20 / 92$ & $-4.62 \mathrm{E}-03$ & $3.62 \mathrm{E}-02$ & $3.62 \mathrm{E}-02$ & * \\
\hline F Slough & Muscle & Cs -137 & $5 / 20 / 92$ & $7.60 \mathrm{E}-03$ & $3.01 \mathrm{E}-02$ & 3.01E-02 & * \\
\hline F Slough & Muscle & Cs-137 & $5 / 20 / 92$ & 8.34E-03 & 2.62E-02 & $2.62 \mathrm{E}-02$ & $*$ \\
\hline F Slough & Muscle & Cs-137 & $5 / 20 / 92$ & 2.51E-02 & $2.90 \mathrm{E}-02$ & 2.91E-02 & * \\
\hline F Slough & Muscle & Cs-137 & $5 / 20 / 92$ & $4.76 \mathrm{E}-02$ & 2.63E-02 & 2.67E-02 & \\
\hline F Slough & Muscle & Sr-90 & $6 / 9 / 83$ & $-1.46 \mathrm{E}-03$ & 2.18E-03 & Not reported & $*$ \\
\hline F Slough & Muscle & Sr -90 & $6 / 9 / 83$ & $7.36 \mathrm{E}-04$ & 2.21E-03 & Not reported & * \\
\hline F Slough & Muscle & Sr-90 & $6 / 9 / 83$ & $1.64 \mathrm{E}-03$ & $2.85 \mathrm{E}-03$ & Not reported & * \\
\hline F Slough & Muscle & Sr-90 & $6 / 9 / 83$ & $4.87 \mathrm{E}-03$ & $2.44 \mathrm{E}-03$ & Not reported & \\
\hline F Slough & Muscle & Sr-90 & $6 / 9 / 83$ & $5.29 \mathrm{E}-03$ & 2.33E-03 & Not reported & \\
\hline F Slough & Muscle & Sr-90 & $5 / 18 / 84$ & $-1.21 \mathrm{E}-04$ & $1.78 \mathrm{E}-03$ & $1.78 \mathrm{E}-03$ & $*$ \\
\hline F Slough & Muscle & Sr-90 & $5 / 18 / 84$ & 6.19E-04 & $2.82 \mathrm{E}-03$ & 2.83E-03 & $*$ \\
\hline F Slough & Muscle & $\mathrm{Sr}-90$ & $5 / 18 / 84$ & $2.05 E-03$ & $1.64 \mathrm{E}-03$ & $1.68 \mathrm{E}-03$ & \\
\hline F Slough & Muscle & Sr-90 & $5 / 18 / 84$ & $2.42 \mathrm{E}-03$ & 2.12E-03 & $2.18 \mathrm{E}-03$ & \\
\hline F Slough & Muscle & Sr-90 & $5 / 18 / 84$ & $2.55 \mathrm{E}-03$ & 2.71E-03 & $2.75 E-03$ & $*$ \\
\hline F Slough & Muscle & Sr-90 & $5 / 24 / 85$ & $1.01 E-03$ & 1.71E-03 & $1.72 \mathrm{E}-03$ & $*$ \\
\hline F Slough & Muscle & Sr-90 & $5 / 24 / 85$ & $1.18 \mathrm{E}-03$ & $2.03 E-03$ & $2.04 \mathrm{E}-03$ & $*$ \\
\hline F Slough & Muscle & Sr-90 & $5 / 24 / 85$ & $3.29 \mathrm{E}-03$ & 1.77E-03 & $1.89 \mathrm{E}-03$ & \\
\hline F Slough & Muscle & Sr-90 & $5 / 24 / 85$ & $4.40 \mathrm{E}-03$ & $1.80 \mathrm{E}-03$ & $2.00 \mathrm{E}-03$ & \\
\hline F Slough & Muscle & Sr-90 & $5 / 31 / 85$ & $1.62 \mathrm{E}-04$ & $2.38 \mathrm{E}-03$ & $2.38 \mathrm{E}-03$ & $*$ \\
\hline F Slough & Muscle & Sr-90 & $5 / 16 / 86$ & $2.76 \mathrm{E}-03$ & $2.36 \mathrm{E}-03$ & $2.45 \mathrm{E}-03$ & \\
\hline F Slough & Muscle & Sr-90 & $5 / 16 / 86$ & $2.78 \mathrm{E}-03$ & $1.75 \mathrm{E}-03$ & $1.85 \mathrm{E}-03$ & \\
\hline F Slough & Muscle & Sr-90 & $5 / 16 / 86$ & $3.66 \mathrm{E}-03$ & $2.17 \mathrm{E}-03$ & $2.30 \mathrm{E}-03$ & \\
\hline F Slough & Muscle & Sr-90 & $5 / 16 / 86$ & 5.85E-03 & $3.51 \mathrm{E}-03$ & $3.74 \mathrm{E}-03$ & \\
\hline F Slough & Muscle & Sr-90 & $5 / 29 / 86$ & 2.23E-02 & $3.46 \mathrm{E}-03$ & $5.61 \mathrm{E}-03$ & \\
\hline F Slough & Muscle & Sr-90 & $5 / 6 / 87$ & $2.37 \mathrm{E}-03$ & $4.22 \mathrm{E}-03$ & 4.39E-03 & $*$ \\
\hline F Slough & Muscle & Sr-90 & $5 / 11 / 87$ & $1.93 \mathrm{E}-03$ & $3.08 \mathrm{E}-03$ & 3.27E-03 & * \\
\hline F Slough & Muscle & Sr-90 & $5 / 11 / 87$ & 4.33E-03 & $3.30 \mathrm{E}-03$ & $3.64 \mathrm{E}-03$ & \\
\hline F Slough & Muscle & Sr-90 & $5 / 21 / 87$ & $2.92 \mathrm{E}-03$ & 4.01E-03 & $4.24 \mathrm{E}-03$ & $*$ \\
\hline F Slough & Muscle & Sr-90 & $5 / 21 / 87$ & $5.62 \mathrm{E}-03$ & $3.12 \mathrm{E}-03$ & $3.68 \mathrm{E}-03$ & \\
\hline F Slough & Muscle & Sr-90 & $5 / 10 / 88$ & 3.05E-03. & $2.96 \mathrm{E}-03$ & $3.26 \mathrm{E}-03$ & $*$ \\
\hline F Slough & Muscle & Sr-90 & $5 / 27 / 88$ & $1.22 \mathrm{E}-03$ & $1.91 \mathrm{E}-03$ & 2.09E-03 & $*$ \\
\hline F Slough & Muscle & Sr-90 & $5 / 27 / 88$ & $1.53 \mathrm{E}-03$ & $2.25 \mathrm{E}-03$ & $2.49 \mathrm{E}-03$ & $*$ \\
\hline F Slough & Muscle & Sr-90 & $6 / 2 / 88$ & $9.04 \mathrm{E}-04$ & $1.80 \mathrm{E}-03$ & $1.98 \mathrm{E}-03$ & $*$ \\
\hline F Slough & Muscle & Sr-90 & $6 / 2 / 88$ & $1.75 \mathrm{E}-03$ & $2.16 \mathrm{E}-03$ & $2.43 \mathrm{E}-03$ & * \\
\hline F Slough & Muscle & Sr-90 & $4 / 25 / 89$ & $1.10 \mathrm{E}-03$ & $1.58 \mathrm{E}-03$ & 1.74E-03 & $*$ \\
\hline F Slough & Muscle & Sr-90. & $4 / 26 / 89$ & 3.12E-04 & $1.74 \mathrm{E}-03$ & $1.89 \mathrm{E}-03$ & $*$ \\
\hline F Slough & Muscle & $\mathrm{Sr}-90$ & $4 / 27 / 89$ & $3.84 \mathrm{E}-04$ & 2.37E-03 & 2.60E-03 & * \\
\hline F Slough & Muscle & Sr-90 & $5 / 1 / 89$ & $9.84 \mathrm{E}-05$ & $2.20 \mathrm{E}-03$ & 2.38E-03 & $*$ \\
\hline F Slough & Muscle & Sr-90 & $5 / 3 / 89$ & $3.31 \mathrm{E}-04$ & $1.78 \mathrm{E}-03$ & $1.97 \mathrm{E}-03$ & $*$ \\
\hline F Slough & Muscle & Sr-90 & $5 / 17 / 90$ & 8.91E-04 & $1.90 \mathrm{E}-03$ & 2.07E-03 & * \\
\hline F Slough & Muscle & Sr-90 & $5 / 18 / 90$ & 9.03E-04 & $2.15 \mathrm{E}-03$ & 2.35E-03 & * \\
\hline
\end{tabular}

- indicates the analytical error exceeds the result (counting error is used when the analytical error is not reported) 
Table A.1. Radionuclide Concentrations in Bass, 1983-1992 (continued)

\begin{tabular}{|c|c|c|c|c|c|c|}
\hline Location & Tissue & Radionuclide & $\begin{array}{c}\text { Date } \\
(\mathrm{M} / \mathrm{D} / \mathrm{Y}) \\
\end{array}$ & $\begin{array}{l}\text { Concentration } \\
\text { (pCi/g wet) }\end{array}$ & $\begin{array}{l}\text { Counting } \\
\text { Error } \\
\text { (pCi/g wet) }\end{array}$ & $\begin{array}{l}\text { Propagated } \\
\text { Analytical } \\
\text { Error } \\
\text { (pCi/g wet) }\end{array}$ \\
\hline F Slough & Muscle & Sr-90 & $5 / 18 / 90$ & $1.69 \mathrm{E}-03$ & $2.32 \mathrm{E}-03$ & $2.50 \mathrm{E}-03$ \\
\hline F Slough & Muscle & Sr-90 & $5 / 20 / 90$ & $-2.90 \mathrm{E}-04$ & 2.34E-03 & $2.48 \mathrm{E}-03$ \\
\hline F Slough & Muscle & Sr-90 & $7 / 5 / 90$ & $1.55 \mathrm{E}-03$ & $3.87 \mathrm{E}-03$ & 4.10E-03 \\
\hline F Slough & Muscle & Sr-90 & $5 / 20 / 92$ & $-7.77 \mathrm{E}-06$ & $1.88 \mathrm{E}-03$ & $2.09 \mathrm{E}-03$ \\
\hline F Slough & Muscle & Sr-90 & $5 / 20 / 92$ & $3.42 \mathrm{E}-04$ & $1.84 \mathrm{E}-03$ & $2.06 \mathrm{E}-03$ \\
\hline F Slough & Muscle & Sr-90 & $5 / 20 / 92$ & 9.19E-04 & 2.15E-03 & $2.35 \mathrm{E}-03$ \\
\hline F Slough & Muscle & Sr-90 & $5 / 20 / 92$ & $1.09 \mathrm{E}-03$ & $1.87 \mathrm{E}-03$ & $2.10 \mathrm{E}-03$ \\
\hline F Slough & Muscle & Sr-90 & $5 / 20 / 92$ & $1.61 \mathrm{E}-03$ & 2.11E-03 & $2.34 \mathrm{E}-03$ \\
\hline Sunnyside & Carcass & $\mathrm{Sr}-90$ & $10 / 14 / 91$ & $-1.28 \mathrm{E}-03$ & 3.36E-03 & $3.90 \mathrm{E}-03$ \\
\hline Sunnyside & Carcass & Sr-90 & $10 / 14 / 91$ & $2.63 \mathrm{E}-03$ & $1.97 \mathrm{E}-03$ & $2.23 \mathrm{E}-03$ \\
\hline Sunnyside & Carcass & Sr-90 & $10 / 14 / 91$ & $2.81 \mathrm{E}-03$ & 2.62E-03 & $2.88 \mathrm{E}-03$ \\
\hline Sunnyside & Carcass & Sr-90 & $10 / 14 / 91$ & $2.88 \mathrm{E}-03$ & $2.54 \mathrm{E}-03$ & $2.78 \mathrm{E}-03$ \\
\hline Sunnyside & Carcass & Sr-90 & $10 / 14 / 91$ & $2.97 \mathrm{E}-03$ & $1.92 \mathrm{E}-03$ & 2.17E-03 \\
\hline Sunnyside & Carcass & Sr-90 & $10 / 14 / 91$ & $3.28 \mathrm{E}-03$ & $2.86 \mathrm{E}-03$ & 3.13E-03 \\
\hline Sunnyside & Carcass & Sr-90 & $10 / 14 / 91$ & $3.58 \mathrm{E}-03$ & $3.00 \mathrm{E}-03$ & $3.21 \mathrm{E}-03$ \\
\hline Sunnyside & Carcass & Sr-90 & $10 / 14 / 91$ & 3.89E-03 & $2.24 \mathrm{E}-03$ & $2.53 \mathrm{E}-03$ \\
\hline Sunnyside & Carcass & Sr-90 & $10 / 14 / 91$ & $4.00 \mathrm{E}-03$ & 2.07E-03 & $2.40 \mathrm{E}-03$ \\
\hline Sunnyside & Carcass & Sr-90 & $10 / 14 / 91$ & $5.20 \mathrm{E}-03$ & 2.07E-03 & $2.44 \mathrm{E}-03$ \\
\hline Sunnyside & Carcass & Sr-90 & $10 / 14 / 91$ & 5.70E-03 & $2.98 \mathrm{E}-03$ & 3.29E-03 \\
\hline Sunnyside & Carcass & Sr-90 & $10 / 14 / 91$ & $5.79 \mathrm{E}-03$ & 2.61E-03 & 2.95E-03 \\
\hline Sunnyside & Carcass & Sr-90 & $10 / 14 / 91$ & $6.58 \mathrm{E}-03$ & $2.46 \mathrm{E}-03$ & 2.93E-03 \\
\hline Sunnyside & Carcass & Sr-90 & $10 / 14 / 91$ & $7.02 \mathrm{E}-03$ & $3.18 \mathrm{E}-03$ & $3.56 \mathrm{E}-03$ \\
\hline Sunnyside & Carcass & Sr-90 & $10 / 14 / 91$ & 7.65E-03 & $2.90 \mathrm{E}-03$ & 3.39E-03 \\
\hline Sunnyside & Carcass & Sr-90 & $10 / 14 / 91$ & 8.28E-03 & 6.03E-03 & $6.42 \mathrm{E}-03$ \\
\hline Sunnyside & Carcass & Sr-90 & $10 / 14 / 91$ & 8.64E-03 & $2.98 \mathrm{E}-03$ & $3.51 \mathrm{E}-03$ \\
\hline Sunnyside & Carcass & Sr-90 & $10 / 14 / 91$ & $1.02 \mathrm{E}-02$ & $2.92 \mathrm{E}-03$ & $3.58 \mathrm{E}-03$ \\
\hline Sunnyside & Carcass & Sr-90 & $10 / 14 / 91$ & $2.05 \mathrm{E}-02$ & 4.20E-03 & $5.86 \mathrm{E}-03$ \\
\hline Sunnyside & Carcass & Sr-90 & $10 / 14 / 91$ & 3.23E-02 & 4.93E-03 & 9.38E-03 \\
\hline Sunnyside & Muscle & Co-60 & $10 / 14 / 91$ & $-2.68 \mathrm{E}-02$ & $5.93 \mathrm{E}-02$ & $5.94 \mathrm{E}-02$ \\
\hline Sunnyside & Muscle & Co-60 & $10 / 14 / 91$ & $-1.58 \mathrm{E}-02$ & $3.74 \mathrm{E}-02$ & $3.75 \mathrm{E}-02$ \\
\hline Sunnyside & Muscle & Co-60 & $10 / 14 / 91$ & $-5.77 \mathrm{E}-03$ & $5.00 \mathrm{E}-02$ & $5.00 \mathrm{E}-02$ \\
\hline Sunnyside & Muscle & Co-60 & $10 / 14 / 91$ & $-4.99 E-03$ & 5.37E-02 & 5.37E-02 \\
\hline Sunnyside & Muscle & Co-60 & $10 / 14 / 91$ & $-2.14 \mathrm{E}-03$ & $3.68 \mathrm{E}-02$ & $3.68 \mathrm{E}-02$ \\
\hline Sunnyside & Muscle & Co-60 & $10 / 14 / 91$ & $3.70 \mathrm{E}-03$ & $5.55 \mathrm{E}-02$ & 5.55E-02 \\
\hline Sunnyside & Muscle & Co-60 & $10 / 14 / 91$ & $4.28 \mathrm{E}-03$ & 4.45E-02 & $4.45 \mathrm{E}-02$ \\
\hline Sunnyside & Muscle & Co-60 & $10 / 14 / 91$ & $6.74 \mathrm{E}-03$ & 8.63E-02 & 8.63E-02 \\
\hline Sunnyside & Muscle & Co-60 & $10 / 14 / 91$ & $1.11 \mathrm{E}-02$ & 6.30E-02 & $6.30 \mathrm{E}-02$ \\
\hline Sunnyside & Muscle & Co-60 & $10 / 14 / 91$ & $1.27 \mathrm{E}-02$ & 4.74E-02 & $4.74 \mathrm{E}-02$ \\
\hline Sunnyside & Muscle & $\mathrm{Co}-60$ & $10 / 14 / 91$ & $1.40 \mathrm{E}-02$ & 5.35E-02 & $5.35 E-02$ \\
\hline Sunnyside & Muscle & Co-60 & $10 / 14 / 91$ & $1.57 \mathrm{E}-02$ & $5.76 \mathrm{E}-02$ & $5.76 \mathrm{E}-02$ \\
\hline Sunnyside & Muscle & Co-60 & $10 / 14 / 91$ & $1.63 \mathrm{E}-02$ & 7.49E-02 & $7.49 \mathrm{E}-02$ \\
\hline Sunnyside & Muscle & Co-60 & $10 / 14 / 91$ & $1.93 \mathrm{E}-02$ & $4.58 \mathrm{E}-02$ & $4.58 \mathrm{E}-02$ \\
\hline Sunnyside & Muscle & Co-60 & $10 / 14 / 91$ & $2.22 \mathrm{E}-02$ & 4.44E-02 & $4.44 \mathrm{E}-02$ \\
\hline
\end{tabular}

* indicates the analytical error exceeds the result (counting error is used when the analytical error is not reported) 
Table A.1. Radionuclide Concentrations in Bass, 1983-1992 (continued)

\begin{tabular}{|c|c|c|c|c|c|c|}
\hline Location & Tissue & Radionuclide & $\begin{array}{c}\text { Date } \\
(\mathrm{M} / \mathrm{D} / \mathrm{Y})\end{array}$ & $\begin{array}{c}\text { Concentration } \\
\text { (pCi/g wet) }\end{array}$ & $\begin{array}{c}\text { Error } \\
\text { (pCi/g wet) }\end{array}$ & $\begin{array}{c}\text { Error } \\
\text { (pCi/g wet) }\end{array}$ \\
\hline Sunnyside & $\overline{\text { Muscle }}$ & Co-60 & $10 / 14 / 91$ & $2.26 \mathrm{E}-02$ & $5.52 \mathrm{E}-02$ & $5.53 \mathrm{E}-02$ \\
\hline Sunnyside & Muscle & Co-60 & $10 / 14 / 91$ & $3.27 \mathrm{E}-02$ & 4.54E-02 & 4.55E-02 \\
\hline Sunnyyside & Muscle & $\mathrm{Co}-60$ & $10 / 14 / 91$ & $6.98 \mathrm{E}-02$ & 5.23E-02 & $5.28 \mathrm{E}-02$ \\
\hline Sunnyside & Muscle & Co-60 & $10 / 14 / 91$ & $7.23 E-02$ & 8.42E-02 & 8.45E-02 \\
\hline Sunnyside & Muscle & $\mathrm{Co}-60$ & $10 / 14 / 91$ & $1.26 \mathrm{E}-01$ & $8.41 \mathrm{E}-02$ & 8.50E-02 \\
\hline Sunnyside & Muscle & Cs-137 & $10 / 14 / 91$ & $-7.75 \mathrm{E}-02$ & 4.15E-02 & 4.22E-02 \\
\hline Sunnyside & Muscle & Cs-137 & $10 / 14 / 91$ & $-4.37 E-02$ & $5.14 \mathrm{E}-02$ & $5.15 E-02$ \\
\hline Sunnyside & Muscle & Cs-137 & $10 / 14 / 91$ & $-3.09 E-02$ & $4.66 \mathrm{E}-02$ & 4.67E-02 \\
\hline Sunnyside & Muscle & Cs-137 & $10 / 14 / 91$ & $-2.45 E-02$ & 6.89E-02 & $6.89 \mathrm{E}-02$ \\
\hline Sunnyside & Muscle & Cs-137 & $10 / 14 / 91$ & $-2.17 E-02$ & 4.78E-02 & 4.79E-02 \\
\hline Sunnyside & Muscle & Cs-137 & $10 / 14 / 91$ & $-7.41 \mathrm{E}-03$ & 5.35E-02 & $5.35 \mathrm{E}-02$ \\
\hline Sunnyside & Muscle & Cs-137 & $10 / 14 / 91$ & $-2.33 E-03$ & 5.33E-02 & 5.33E-02 \\
\hline Sunnyside & Muscle & Cs-137 & $10 / 14 / 91$ & $4.91 E-03$ & $4.29 E-02$ & 4.29E-02 \\
\hline Sunnyside & Muscle & Cs-137 & $10 / 14 / 91$ & $7.59 \mathrm{E}-03$ & $6.26 \mathrm{E}-02$ & $6.26 \mathrm{E}-02$ \\
\hline Sunnyside & Muscle & Cs- 137 & $10 / 14 / 91$ & $1.13 \mathrm{E}-02$ & $3.83 \mathrm{E}-02$ & $3.84 \mathrm{E}-02$ \\
\hline Sunnyside & Muscle & Cs-137 & $10 / 14 / 91$ & $1.21 \mathrm{E}-02$ & $5.15 E-02$ & $5.15 \mathrm{E}-02$ \\
\hline Sunnyside & Muscle & Cs-137 & $10 / 14 / 91$ & $1.48 \mathrm{E}-02$ & $5.55 \mathrm{E}-02$ & $5.56 \mathrm{E}-02$ \\
\hline Sunnyside & Muscle & Cs-137 & $10 / 14 / 91$ & $1.76 \mathrm{E}-02$ & 4.85E-02 & $4.86 \mathrm{E}-02$ \\
\hline Sunnyside & Muscle & Cs- 137 & $10 / 14 / 91$ & $3.08 \mathrm{E}-02$ & $5.00 \mathrm{E}-02$ & 5.01E-02 \\
\hline Sunnyside & Muscle & Cs-137 & $10 / 14 / 91$ & 3.19E-02 & 4.02E-02 & $4.04 \mathrm{E}-02$ \\
\hline Sunnyside & Muscle & Cs-137 & $10 / 14 / 91$ & $3.87 \mathrm{E}-02$ & $6.45 \mathrm{E}-02$ & $6.46 \mathrm{E}-02$ \\
\hline Sunnyside & Muscle & Cs-137 & $10 / 14 / 91$ & 4.43E-02 & $4.84 \mathrm{E}-02$ & $4.86 \mathrm{E}-02$ \\
\hline Sunnyside & Muscle & Cs-137 & $10 / 14 / 91$ & $5.51 \mathrm{E}-02$ & $6.24 \mathrm{E}-02$ & $6.26 \mathrm{E}-02$ \\
\hline Sunnyside & Muscle & Cs-137 & $10 / 14 / 91$ & 8.48E-02 & $7.89 \mathrm{E}-02$ & 7.94E-02 \\
\hline Sunnyside & Muscle & Cs-137 & $10 / 14 / 91$ & 8.57E-02 & 8.93E-02 & 8.97E-02 \\
\hline Sunnyside & Muscle & Sr-90 & $10 / 14 / 91$ & $-3.25 E-03$ & $5.17 \mathrm{E}-03$ & 5.29E-03 \\
\hline Sunnyside & Muscle & Sr-90 & $10 / 14 / 91$ & $-8.43 E-04$ & $3.49 \mathrm{E}-03$ & $3.80 \mathrm{E}-03$ \\
\hline Sunnyside & Muscle & Sr-90 & $10 / 14 / 91$ & $-3.86 E-04$ & $3.91 E-03$ & 4.00E-03 \\
\hline Sunnyside & Muscle & Sr-90 & $10 / 14 / 91$ & $-3.06 \mathrm{E}-04$ & 5.45E-03 & 5.66E-03 \\
\hline Sunnyside & Muscle & Sr-90 & $10 / 14 / 91$ & $-1.68 \mathrm{E}-04$ & $2.61 \mathrm{E}-03$ & $2.90 \mathrm{E}-03$ \\
\hline Sunnyside & Muscle & Sr-90 & $10 / 14 / 91$ & $1.44 \mathrm{E}-04$ & $3.45 \mathrm{E}-03$ & $3.61 \mathrm{E}-03$ \\
\hline Sunnyside & Muscle & Sr-90 & $10 / 14 / 91$ & $1.67 \mathrm{E}-04$ & $1.48 \mathrm{E}-03$ & $1.67 \mathrm{E}-03$ \\
\hline Sunnyside & Muscle & Sr-90 & $10 / 14 / 91$ & $1.83 \mathrm{E}-04$ & $5.40 \mathrm{E}-03$ & $5.49 \mathrm{E}-03$ \\
\hline Sunnyside & Muscle & Sr-90 & $10 / 14 / 91$ & $2.46 \mathrm{E}-04$ & $5.85 \mathrm{E}-03$ & $5.95 \mathrm{E}-03$ \\
\hline Sunnyside & Muscle & Sr-90 & $10 / 14 / 91$ & $3.15 \mathrm{E}-04$ & 5.91E-03 & $6.43 \mathrm{E}-03$ \\
\hline Sunnyside & Muscle & Sr-90 & $10 / 14 / 91$ & 4.29E-04 & $5.14 \mathrm{E}-03$ & 5.32E-03 \\
\hline Sunnyside & Muscle & Sr-90 & $10 / 14 / 9.1$ & 8.64E-04 & $3.54 \mathrm{E}-03$ & 3.99E-03 \\
\hline Sunnyside & Muscle & Sr-90 & $10 / 14 / 91$ & $1.01 E-03$ & $5.21 \mathrm{E}-03$ & $5.65 \mathrm{E}-03$ \\
\hline Sunnyside & Muscle & Sr-90 & $10 / 14 / 91$ & $1.08 \mathrm{E}-03$ & $2.83 \mathrm{E}-03$ & 3.04E-03 \\
\hline Sunnyside & Muscle & Sr-90 & $10 / 14 / 91$ & 1.13E-03 & 4.23E-03 & 4.31E-03 \\
\hline Sunnyside & Muscle & Sr-90 & $10 / 14 / 91$ & $1.16 \mathrm{E}-03$ & 2.52E-03 & 2.71E-03 \\
\hline Sunnyside & Muscle & Sr-90 & $10 / 14 / 91$ & $1.35 \mathrm{E}-03$ & 3.79E-03 & 4.05E-03 \\
\hline Sunnyside & Muscle & Sr-90 & $10 / 14 / 91$ & $1.78 \mathrm{E}-03$ & 5.61E-03 & 5.69E-03 \\
\hline
\end{tabular}

- indicates the analytical error exceeds the result (counting error is used when the analytical error is not reported) 
Table A.1. Radionuclide Concentrations in Bass, 1983-1992 (continued)

$\begin{array}{llcccccc}\text { Location } & \text { Tissue } & \text { Radionuclide } & \begin{array}{c}\text { Date } \\ \text { (M/D/Y) }\end{array} & \begin{array}{c}\text { Concentration } \\ (\mathrm{pCi} / \mathrm{g} \text { wet) }\end{array} & \begin{array}{c}\text { Counting } \\ \text { Error } \\ \text { (pCi/g wet) }\end{array} & \begin{array}{c}\text { Propagated } \\ \text { Analytical } \\ \text { Error }\end{array} \\ \text { Sunnyside } & \text { Muscle } & \frac{\mathrm{pCi} / \mathrm{g} \text { wet) }}{\text { Sr-90 }} & 10 / 14 / 91 & 1.83 \mathrm{E}-03 & 4.22 \mathrm{E}-03 & 4.34 \mathrm{E}-03 & * \\ \text { Sunnyside } & \text { Muscle } & \mathrm{Sr}-90 & 10 / 14 / 91 & 1.91 \mathrm{E}-03 & 3.93 \mathrm{E}-03 & 4.20 \mathrm{E}-03 & *\end{array}$

* indicates the analytical error exceeds the result (counting error is used when the analytical error is not reported) 
Table A.2. Radionuclide Concentrations in Carp, 1990-1992 (continued)

\begin{tabular}{|c|c|c|c|c|c|c|c|}
\hline Location & Tissue & Radionuclide & $\begin{array}{c}\text { Date } \\
(\mathrm{M} / \mathrm{D} / \mathrm{Y})\end{array}$ & $\begin{array}{c}\text { Concentration } \\
\text { (pCi/g wet) }\end{array}$ & $\begin{array}{l}\text { Counting } \\
\text { Error } \\
\text { (pCi/g wet) }\end{array}$ & $\begin{array}{c}\text { Propagated } \\
\text { Analytical } \\
\text { Error } \\
\text { (pCi/g wet) }\end{array}$ & \\
\hline $100 \mathrm{~N}$ & $\overline{\text { Muscle }}$ & Co-60 & $9 / 21 / 90$ & $-9.39 E-04$ & $8.13 \mathrm{E}-03$ & $8.13 \mathrm{E}-03$ & $*$ \\
\hline $100 N$ & Muscle & Co-60 & $9 / 21 / 90$ & $6.93 \mathrm{E}-03$ & $2.58 \mathrm{E}-02$ & $2.58 \mathrm{E}-02$ & $*$ \\
\hline $100 \mathrm{~N}$ & Muscle & $\mathrm{Co}-60$ & $9 / 21 / 90$ & $-6.00 E-03$ & $9.29 \mathrm{E}-03$ & $9.31 \mathrm{E}-03$ & * \\
\hline $100 \mathrm{~N}$ & Muscle & Co-60 & $9 / 21 / 90$ & $2.68 \mathrm{E}-03$ & 7.53E-03 & 7.53E-03 & $*$ \\
\hline $100 \mathrm{~N}$ & Muscle & $\mathrm{Co}-60$ & $9 / 21 / 90$ & $1.49 \mathrm{E}-02$ & $2.29 E-02$ & $2.30 \mathrm{E}-02$ & $*$ \\
\hline $100 \mathrm{~N}$ & Muscle & Co-60 & $10 / 21 / 90$ & $5.53 \mathrm{E}-03$ & $2.42 \mathrm{E}-02$ & $2.42 \mathrm{E}-02$ & $*$ \\
\hline $100 \mathrm{~N}$ & Muscle & Co-60 & $.8 / 15 / 91$ & $-1.31 E-02$ & $1.41 \mathrm{E}-02$ & $1.42 E-02$ & $*$ \\
\hline $100 \mathrm{~N}$ & Muscle & Co-60 & $8 / 15 / 91$ & $3.25 \mathrm{E}-04$ & $7.75 \mathrm{E}-03$ & $7.75 \mathrm{E}-03$ & $*$ \\
\hline $100 \mathrm{~N}$ & Muscle & Co-60 & $8 / 16 / 91$ & $8.53 \mathrm{E}-03$ & $2.38 \mathrm{E}-02$ & 2.38E-02 & $*$ \\
\hline $100 \mathrm{~N}$ & Muscle & Co-60 & $8 / 16 / 91$ & $-4.34 E-03$ & $1.99 \mathrm{E}-02$ & $1.99 \mathrm{E}-02$ & $*$ \\
\hline $100 N$ & Muscle & Co- 60 & $11 / 17 / 92$ & $1.04 \mathrm{E}-02$ & $6.12 \mathrm{E}-03$ & $6.21 \mathrm{E}-03$ & \\
\hline $300 \mathrm{~A}$ & Muscle & Co-60 & $10 / 9 / 91$ & $8.05 \mathrm{E}-03$ & $1.05 \mathrm{E}-02$ & $1.05 \mathrm{E}-02$ & $*$ \\
\hline $300 \mathrm{~A}$ & Muscle & Co-60 & $10 / 9 / 91$ & $-3.31 E-02$ & $2.84 \mathrm{E}-02$ & $2.86 \mathrm{E}-02$ & $*$ \\
\hline $300 \mathrm{~A}$ & Muscle & Co-60 & $10 / 9 / 91$ & 8.05E-03 & $1.05 \mathrm{E}-02$ & $1.05 E-02$ & $*$. \\
\hline $300 \mathrm{~A}$ & Muscle & Co-60 & $10 / 9 / 91$ & $-1.19 E-02$ & $2.43 E-02$ & $2.43 E-02$ & * \\
\hline $300 \mathrm{~A}$ & Muscle & Co- 60 & $10 / 9 / 91$ & $7.11 \mathrm{E}-03$ & $5.95 \mathrm{E}-03$ & $6.00 \mathrm{E}-03$ & \\
\hline $300 \mathrm{~A}$ & Muscle & Co-60 & $6 / 25 / 92$ & $7.40 \mathrm{E}-03$ & $9.73 \mathrm{E}-03$ & $9.76 \mathrm{E}-03$ & $*$ \\
\hline $300 \mathrm{~A}$ & Muscle & Co-60 & $6 / 25 / 92$ & $-3.42 E-03$ & $1.30 \mathrm{E}-02$ & $1.30 \dot{\mathrm{E}}-02$ & $*$ \\
\hline $300 \mathrm{~A}$ & Muscle & Co-60 & $6 / 25 / 92$ & $3.23 \mathrm{E}-04$ & $7.69 E-03$ & $7.69 \mathrm{E}-03$ & * \\
\hline $300 \mathrm{~A}$ & Muscle & Co-60 & $6 / 25 / 92$ & $-4.80 E-03$ & $9.22 \mathrm{E}-03$ & $9.23 \mathrm{E}-03$ & $*$ \\
\hline $300 \mathrm{~A}$ & Muscle & Co-60 & $6 / 25 / 92$ & $-9.58 E-04$ & $1.30 \mathrm{E}-02$ & $1.30 E-02$ & $*$ \\
\hline Vantage & Muscle & Co-60 & $9 / 25 / 90$ & $-5.96 \mathrm{E}-03$ & 8.32E-03 & 8.34E-03 & * \\
\hline Vantage & Muscle & Co-60 & $9 / 25 / 90$ & $-1.10 \mathrm{E}-02$ & $1.18 \mathrm{E}-02$ & $1.18 \mathrm{E}-02$ & * \\
\hline Vantage & Muscle & Co-60 & $9 / 25 / 90$ & $6.33 \mathrm{E}-03$ & $7.86 \mathrm{E}-03$ & $7: 88 \mathrm{E}-03$ & * \\
\hline Vantage & Muscle & Co-60 & $7 / 17 / 9.1$ & $-7.50 \mathrm{E}-04$ & 8.37E-03 & 8.37E-03 & * \\
\hline Vantage & Muscle & Co-60 & $7 / 17 / 91$ & $6.26 \mathrm{E}-04$ & 8.01E-03 & 8.01E-03 & $*$ \\
\hline Vantage & Muscle & Co-60 & $7 / 17 / 91$ & $-1.32 E-03$ & 7.30E-03 & 7.30E-03 & $*$ \\
\hline Vantage & Muscle & Co-60 & $7 / 17 / 91$ & $-3.06 E-03$ & $6.77 E-03$ & $6.78 \mathrm{E}-03$ & $*$ \\
\hline Vantage & Muscle & Co-60 & $7 / 17 / 91$ & $1.29 \mathrm{E}-02$ & $8.02 E-03$ & $8.12 \mathrm{E}-03$ & \\
\hline Vantage & Muscle & Co-60 & $7 / 17 / 91$ & $5.26 \mathrm{E}-03$ & $1.05 \mathrm{E}-02$ & $1.05 \mathrm{E}-02$ & $*$ \\
\hline Vantage & Muscle & Co-60 & $7 / 17 / 91$ & $-2.08 E-03$ & $8.68 \mathrm{E}-03$ & $8.68 \mathrm{E}-03$ & $*$ \\
\hline Vantage & Muscle & Co-60 & $7 / 17 / 91$ & 5.49E-03 & 6.79E-03 & $6.81 \mathrm{E}-03$ & $*$. \\
\hline Vantage & Muscle & Co-60 & $7 / 17 / 91$ & 5.19E-03 & $1.06 \mathrm{E}-02$ & $1.06 \mathrm{E}-02$ & $*$ \\
\hline Vantage & Muscle & Co-60 & $7 / 17 / 91$ & $7.08 \mathrm{E}-03$ & $1.35 \mathrm{E}-02$ & $1.35 \mathrm{E}-02$ & $*$ \\
\hline $100 N$ & Muscle & Cs-137 & $9 / 21 / 90$ & $1.86 \mathrm{E}-02$ & 8.75E-03 & $8.95 \mathrm{E}-03$ & \\
\hline $100 \mathrm{~N}$ & Muscle & Cs- 137 & $9 / 21 / 90$ & $3.72 E-03$ & $2.36 \mathrm{E}-02$ & $2.36 \mathrm{E}-02$ & $*$ \\
\hline $100 \mathrm{~N}$ & Muscle & Cs- 137 & $9 / 21 / 90$ & 2.89E-03 & 8.67E-03 & 8.67E-03 & $*$ \\
\hline $100 N$ & Muscle & Cs-137 & $9 / 21 / 90$ & $2.32 \mathrm{E}-02$ & $7.75 \mathrm{E}-03$ & 8.09E-03 & \\
\hline $100 \mathrm{~N}$ & Muscle & Cs-137 & $9 / 21 / 90$ & $3.66 \mathrm{E}-02$ & 2.34E-02 & 2.37E-02 & \\
\hline $100 \mathrm{~N}$ & Muscle & Cs-137 & $10 / 21 / 90$ & $1.27 \mathrm{E}-02$ & $2.05 E-02$ & $2.05 \mathrm{E}-02$ & $*$ \\
\hline $100 N$ & Muscle & Cs- 137 & $8 / 15 / 91$ & $4.45 \mathrm{E}-02$ & $1.23 \mathrm{E}-02$ & $1.31 \mathrm{E}-02$ & \\
\hline $100 \mathrm{~N}$ & Muscle & Cs-137 & $8 / 15 / 91$ & $7.45 \mathrm{E}-03$ & $9.25 \mathrm{E}-03$ & $9.28 \mathrm{E}-03$ & $*$ \\
\hline $100 \mathrm{~N}$ & Muscle & Cs-137 & $8 / 16 / 91$ & $2.95 \mathrm{E}-02$ & $2.44 \mathrm{E}-02$ & $2.45 \mathrm{E}-02$ & \\
\hline
\end{tabular}

* indicates the analytical error exceeds the result (counting error is used when the analytical error is not reported) 
Table A.2. Radionuclide Concentrations in Carp, 1990-1992 (continued)

\begin{tabular}{|c|c|c|c|c|c|c|}
\hline Location & Tissue & $\underline{\text { Radionùclide }}$ & $\begin{array}{c}\text { Date } \\
(\mathrm{M} / \mathrm{D} / \mathrm{Y})\end{array}$ & $\begin{array}{c}\text { Concentration } \\
\text { (pCi/g_wet) }\end{array}$ & $\begin{array}{l}\text { Counting } \\
\text { Error } \\
\text { (pCi/g wet) }\end{array}$ & $\begin{array}{l}\text { Propagated } \\
\text { Analytical } \\
\text { Error } \\
\text { (pCi/g wet) }\end{array}$ \\
\hline $100 \mathrm{~N}$ & $\overline{\text { Muscle }}$ & Cs-137 & $8 / 16 / 91$ & $8.55 \mathrm{E}-03$ & $1.68 \mathrm{E}-02$ & $1.68 \mathrm{E}-02$ \\
\hline $100 \mathrm{~N}$ & Muscle & Cs- 137 & $11 / 17 / 92$ & $8.90 \mathrm{E}-03$ & 7.67E-03 & 7.73E-03 \\
\hline $300 \mathrm{~A}$ & Muscle & Cs-137 & $10 / 9 / 91$ & $6.18 \mathrm{E}-03$ & $1.17 \mathrm{E}-02$ & 1.17E-02 \\
\hline $300 \mathrm{~A}$ & Muscle & Cs-137 & $10 / 9 / 91$ & $-1.26 \mathrm{E}-03$ & 2.55E-02 & $2.55 \mathrm{E}-02$ \\
\hline $300 \mathrm{~A}$ & Muscle & Cs-137 & $10 / 9 / 91$ & $6.18 \mathrm{E}-03$ & $1.17 \mathrm{E}-02$ & $1.17 \mathrm{E}-02$ \\
\hline $300 \mathrm{~A}$ & Muscle & Cs-137 & $10 / 9 / 91$ & $3.26 \mathrm{E}-03$ & 2.01E-02 & 2.01E-02 \\
\hline $300 \mathrm{~A}$ & Muscle & Cs-137 & $10 / 9 / 91$ & 5.11E-03 & $5.98 \mathrm{E}-03$ & $6.00 \mathrm{E}-03$ \\
\hline $300 \mathrm{~A}$ & Muscle & Cs-137 & $6 / 25 / 92$ & $5.64 \mathrm{E}-03$ & $1.20 \mathrm{E}-02$ & $1.20 \mathrm{E}-02$ \\
\hline $300 \mathrm{~A}$ & Muscle & Cs-137 & $6 / 25 / 92$ & $6.09 \mathrm{E}-03$ & $1.38 \mathrm{E}-02$ & $1.38 \mathrm{E}-02$ \\
\hline $300 \mathrm{~A}$ & Muscle & Cs-137 & $6 / 25 / 92$ & 9.31E-03 & $8.09 \mathrm{E}-03$ & $8.14 \mathrm{E}-03$ \\
\hline $300 \mathrm{~A}$ & Muscle & Cs-137 & $6 / 25 / 92$ & 2.72E-03 & $7.86 \mathrm{E}-03$ & $7.86 \mathrm{E}-03$ \\
\hline $300 \mathrm{~A}$ & Muscle & Cs- 137 & $6 / 25 / 92$ & $1.70 \mathrm{E}-02$ & $1.01 \mathrm{E}-02$ & $1.02 \mathrm{E}-02$ \\
\hline Vantage & Muscle & Cs- 137 & $9 / 25 / 90$ & $6.55 \mathrm{E}-03$ & 4.19E-03 & $4.24 \mathrm{E}-03$ \\
\hline Vantage & Muscle & Cs-137 & $9 / 25 / 90$ & $1.82 \mathrm{E}-03$ & $9.26 \mathrm{E}-03$ & $9.26 \mathrm{E}-03$ \\
\hline Vantage & Muscle & Cs -137 & $9 / 25 / 90$ & $9.65 \mathrm{E}-03$ & $6.81 \mathrm{E}-03$ & $6.88 \mathrm{E}-03$ \\
\hline Vantage & Muscle & Cs- 137 & $7 / 17 / 91$ & 8.08E-03 & $6.45 \mathrm{E}-03$ & $6.50 \mathrm{E}-03$ \\
\hline Vantage & Muscle & Cs-137 & $7 / 17 / 91$ & $3.58 \mathrm{E}-03$ & $7.86 \mathrm{E}-03$ & $7.87 \mathrm{E}-03$ \\
\hline Vantage & Muscle & Cs- 137 & $7 / 17 / 91$ & $9.89 \mathrm{E}-03^{\circ}$ & 6.79E-03 & $6.86 \mathrm{E}-03$ \\
\hline Vantage & Muscle & Cs-137 & $7 / 17 / 91$ & $1.25 \mathrm{E}-02$ & $6.98 \mathrm{E}-03$ & 7.09E-03 \\
\hline Vantage & Muscle & Cs-137 & $7 / 17 / 91$ & $6.26 \mathrm{E}-03$ & 9.23E-03 & $9.25 \mathrm{E}-03$ \\
\hline Vantage & -Muscle & Cs-137 & $7 / 17 / 91$ & $7.96 \mathrm{E}-04$ & $1.07 \mathrm{E}-02$ & $1.07 \mathrm{E}-02$ \\
\hline Vantage & Muscle & Cs- 137 & $7 / 17 / 91$ & $7.24 \mathrm{E}-03$ & 8.11E-03 & $8.14 \mathrm{E}-03$ \\
\hline Vantage & Muscle & Cs- 137 & $7 / 17 / 91$ & 2.14E-04 & $7.23 \mathrm{E}-03$ & 7.23E-03 \\
\hline Vantage & Muscle & Cs-137 & $7 / 17 / 91$ & $9.12 \mathrm{E}-03$ & $7.68 \mathrm{E}-03$ & 7.73E-03 \\
\hline Vantage & Muscle & Cs-137 & $7 / 17 / 91$ & $1.45 \mathrm{E}-02$ & 9.07E-03 & $9.18 \mathrm{E}-03$ \\
\hline $100 N$ & Muscle & Sr-90 & $9 / 21 / 90$ & $-3.40 \mathrm{E}-04$ & $2.30 \mathrm{E}-03$ & $2.48 \mathrm{E}-03$ \\
\hline $100 \mathrm{~N}$ & Muscle & Sr-90 & $9 / 21 / 90$ & $2.17 \mathrm{E}-03$ & $2.26 \mathrm{E}-03$ & $2.49 \mathrm{E}-03$ \\
\hline $100 \mathrm{~N}$ & Muscle & Sr-90 & $9 / 21 / 90$ & $1.56 \mathrm{E}-03$ & $3.74 \mathrm{E}-03$ & 3.87E-03 \\
\hline $100 \mathrm{~N}$ & Muscle & Sr-90 & $9 / 21 / 90$ & $1.66 \mathrm{E}-02$ & 4.70E-03 & $5.70 \mathrm{E}-03$ \\
\hline $100 \mathrm{~N}$ & Muscle & Sr-90 & $9 / 21 / 90$ & $1.68 \mathrm{E}-03$ & $2.04 \mathrm{E}-03$ & $2.26 \mathrm{E}-03$ \\
\hline $100 \mathrm{~N}$ & Muscle & Sr-90 & $10 / 21 / 90$ & $1.02 \mathrm{E}-02$ & 4.48E-03 & $4.96 \mathrm{E}-03$ \\
\hline $100 \mathrm{~N}$ & Muscle & Sr-90 & $8 / 15 / 91$ & 8.17E-03 & $2.83 \mathrm{E}-03$ & 3.39E-03 \\
\hline $100 \mathrm{~N}$ & Muscle & Sr-90 & $8 / 15 / 91$ & $1.27 \mathrm{E}-03$ & 2.82E-03 & $2.98 \mathrm{E}-03$ \\
\hline $100 \mathrm{~N}$ & Muscle & Sr-90 & $8 / 16 / 91$ & $1.47 \mathrm{E}-03$ & $2.20 \mathrm{E}-03$ & 2.42E-03 \\
\hline $100 \mathrm{~N}$ & Muscle & $\mathrm{Sr}-90$ & $8 / 16 / 91$ & $-1.89 \mathrm{E}-03$ & $4.27 \mathrm{E}-03$ & 4.38E-03 \\
\hline $100 \mathrm{~N}$ & Muscle & Sr-90 & $11 / 17 / 92$ & $-4.94 \mathrm{E}-04$ & $1.83 \mathrm{E}-03$ & $2.01 \mathrm{E}-03$ \\
\hline $100 \mathrm{~N}$ & Carcass & Sr-90 & $9 / 21 / 90$ & 4.19E-03 & $2.47 \mathrm{E}-03$ & 2.73E-03 \\
\hline $100 \mathrm{~N}$ & Carcass & Sr-90 & $9 / 21 / 90$ & 2.70E-02 & 5.32E-03 & 7.42E-03 \\
\hline $100 \mathrm{~N}$ & Carcass & Sr -90 & $9 / 21 / 90$ & $1.76 \mathrm{E}-02$ & 4.32E-03 & $5.40 \mathrm{E}-03$ \\
\hline $100 \mathrm{~N}$ & Carcass & Sr-90 & $9 / 21 / 90$ & 4.20E-01 & $1.84 \mathrm{E}-02$ & 7.72E-02 \\
\hline $100 \mathrm{~N}$ & Carcass & Sr-90 & $9 / 21 / 90$ & 1.92E-01 & $1.21 \mathrm{E}-02$ & $3.78 \mathrm{E}-02$ \\
\hline $100 \mathrm{~N}$ & Carcass & Sr -90 & $10 / 21 / 90$ & $1.46 \mathrm{E}-01$ & $1.03 \mathrm{E}-02$ & $2.81 \mathrm{E}-02$ \\
\hline $100 \mathrm{~N}$ & Carcass & Sr-90 & $8 / 15 / 91$ & $2.64 \mathrm{E}-01$ & $1.18 \mathrm{E}-02$ & $5.06 \mathrm{E}-02$ \\
\hline
\end{tabular}

- indicates the analytical error exceeds the result (counting error is used when the analytical error is not reported) 
Table A.2. Radionuclide Concentrations in Carp, 1990-1992 (continued)

\begin{tabular}{|c|c|c|c|c|c|c|}
\hline Location & Tissue & Radionuclide & $\begin{array}{c}\text { Date } \\
(\mathrm{M} / \mathrm{D} / \mathrm{Y})\end{array}$ & $\begin{array}{l}\text { Concentration } \\
\text { (pCi/g wet) }\end{array}$ & $\begin{array}{l}\text { Counting } \\
\text { Error } \\
\text { (pCi/g wet) }\end{array}$ & $\begin{array}{c}\text { Propagated } \\
\text { Analytical } \\
\text { Error } \\
\text { (pCi/g wet) }\end{array}$ \\
\hline $100 N$ & Carcass & Sr-90 & $8 / 15 / 91$ & $1.01 \mathrm{E}-02$ & 3.27E-03 & $3.89 \mathrm{E}-03$ \\
\hline $100 \mathrm{~N}$ & Carcass & Sr-90 & $8 / 16 / 91$ & $4.03 \mathrm{E}-02$ & 4.72E-03 & 8.53E-03 \\
\hline $100 \mathrm{~N}$ & Carcass & $\mathrm{Sr}-90$ & $8 / 16 / 91$ & 2.07E-02 & 3.27E-03 & $4.98 \mathrm{E}-03$ \\
\hline $100 \mathrm{~N}$ & Carcass & Sr -90 & $11 / 17 / 92$ & $1.14 \mathrm{E}-02$ & 7.35E-03 & 7.94E-03 \\
\hline $300 \mathrm{~A}$ & Muscle & $\mathrm{Sr}-90$ & 10/9/91 & $-1.02 E-04$ & $3.93 E-03$ & $4.03 E-03$ \\
\hline $300 \mathrm{~A}$ & Muscle & $\mathrm{Sr}-90$ & 10/9/91 & $2.95 \mathrm{E}-03$ & $4.44 \mathrm{E}-03$ & $4.57 \mathrm{E}-03$ \\
\hline $300 \mathrm{~A}$ & Muscle & Sr-90 & 10/9/91 & $3.81 E-04$ & 2.11E-03 & $2.28 \mathrm{E}-03$ \\
\hline $300 \mathrm{~A}$ & Muscle & Sr-90 & 10/9/91 & $7.36 \mathrm{E}-04$ & 2.07E-03 & 2.23E-03 \\
\hline $300 \mathrm{~A}$ & Muscle & Sr-90 & $10 / 9 / 91$ & 9.39E-04 & $1.96 \mathrm{E}-03$ & $2.14 \mathrm{E}-03$ \\
\hline $300 \mathrm{~A}$ & Muscle & Sr-90 & $6 / 25 / 92$ & $-8.66 \mathrm{E}-04$ & $1.97 \mathrm{E}-03$ & 2.17E-03 \\
\hline $300 \mathrm{~A}$ & Muscle & Sr-90 & $6 / 25 / 92$ & $-1.29 \mathrm{E}-03$ & 2.38E-03 & $2.56 \mathrm{E}-03$ \\
\hline $300 \mathrm{~A}$ & Muscle & Sr-90 & $6 / 25 / 92$ & $5.82 \mathrm{E}-04$ & $2.04 \mathrm{E}-03$ & $2.25 \mathrm{E}-03$ \\
\hline $300 \mathrm{~A}$ & Muscle & $\mathrm{Sr}-90$ & $6 / 25 / 92$ & $-3.59 E-04$ & $2.65 \mathrm{E}-03$ & 2.81E-03 \\
\hline $300 \mathrm{~A}$ & Muscle & Sr-90 & $6 / 25 / 92$ & $1.23 \mathrm{E}-03$ & $2.56 \mathrm{E}-03$ & $2.74 \mathrm{E}-03$ \\
\hline $300 \mathrm{~A}$ & Carcass & $\mathrm{Sr}-90$ & $10 / 9 / 91$ & $5.73 E-03$ & 5.27E-03 & $5.56 \mathrm{E}-03$ \\
\hline $300 \mathrm{~A}$ & Carcass & $\mathrm{Sr}-90$ & $10 / 9 / 91$ & $1.04 \mathrm{E}-02$ & 2.71E-03 & $3.43 \mathrm{E}-03$ \\
\hline $300 \mathrm{~A}$ & Carcass & Sr-90 & $10 / 9 / 91$ & $2.13 E-02$ & 4.11E-03 & $5.69 \mathrm{E}-03$ \\
\hline $300 \mathrm{~A}$ & Carcass & Sr-90 & $10 / 9 / 91$ & 2.02E-02 & $5.38 \mathrm{E}-03$ & $6.54 \mathrm{E}-03$ \\
\hline $300 \mathrm{~A}$ & Carcass & Sr-90 & $10 / 9 / 91$ & $3.58 \mathrm{E}-02$ & $4.65 \mathrm{E}-03$ & $1.01 \mathrm{E}-02$ \\
\hline $300 \mathrm{~A}$ & Carcass & Sr-90 & $6 / 25 / 92$ & $1.18 \mathrm{E}-02$ & $3.88 \mathrm{E}-03$ & $4.58 \mathrm{E}-03$ \\
\hline $300 \mathrm{~A}$ & Carcass & Sr-90 & $6 / 25 / 92$ & $1.37 E-02$ & $3.54 \mathrm{E}-03$ & $4.45 \mathrm{E}-03$ \\
\hline $300 \mathrm{~A}$ & Carcass & $\mathrm{Sr}-90$ & $6 / 25 / 92$ & $4.60 \mathrm{E}-02$ & $6.93 \mathrm{E}-03$ & $1.08 \mathrm{E}-02$ \\
\hline $300 \mathrm{~A}$ & Carcass & Sr-90 & $6 / 25 / 92$ & $2.73 \mathrm{E}-02$ & $5.58 \mathrm{E}-03$ & 7.42E-03 \\
\hline $300 \mathrm{~A}$ & Carcass & Sr -90 & $6 / 25 / 92$ & 2.72E-02 & $4.98 \mathrm{E}-03$ & 7.18E-03 \\
\hline Vantage & Muscle & $\mathrm{Sr}-90$ & $9 / 25 / 90$ & $1.95 \mathrm{E}-03$ & $2.40 \mathrm{E}-03$ & 2.59E-03 \\
\hline Vantage & Muscle & Sr-90 & $9 / 25 / 90$ & $6.61 \mathrm{E}-04$ & $2.01 E-03$ & $2.19 \mathrm{E}-03$ \\
\hline Vantage & Muscle & Sr-90 & $9 / 25 / 90$ & $-2.42 \mathrm{E}-05$ & $2.03 \mathrm{E}-03$ & $2.21 E-03$ \\
\hline Vantage & Muscle & Sr-90 & $7 / 17 / 91$ & $1.53 \mathrm{E}-03$ & $2.34 \mathrm{E}-03$ & $2.54 \mathrm{E}-03$ \\
\hline Vantage & Muscle & Sr -90 & $7 / 17 / 91$ & $1.92 \mathrm{E}-03$ & $2.30 \mathrm{E}-03$ & $2.51 \mathrm{E}-03$ \\
\hline Vantage & Muscle & Sr-90 & $7 / 17 / 91$ & $1.39 \mathrm{E}-03$ & 2.10E-03 & 2.32E-03 \\
\hline Vantage & Muscle & Sr-90 & $7 / 17 / 91$ & $2.28 \mathrm{E}-03$ & $2.22 \mathrm{E}-03$ & $2.47 \mathrm{E}-03$ \\
\hline Vantage & Muscle & Sr-90 & $7 / 17 / 91$ & $1.07 \mathrm{E}-03$ & $2.04 \mathrm{E}-03$ & $2.25 \mathrm{E}-03$ \\
\hline Vantage & Muscle & Sr-90 & $7 / 17 / 91$ & $6.42 \mathrm{E}-05$ & $2.54 \mathrm{E}-03$ & 2.69E-03 \\
\hline Vantage & Muscle & Sr-90 & $7 / 17 / 91$ & 1.91E-03 & $1.93 \mathrm{E}-03$ & $2.16 \mathrm{E}-03$ \\
\hline Vantage & Muscle & Sr-90 & $7 / 17 / 91$ & 1.22E-04 & 1.77E-03 & $1.98 \mathrm{E}-03$ \\
\hline Vantage & Muscle & Sr-90 & $7 / 17 / 91$ & $1.58 \mathrm{E}-04$ & 2.18E-03 & $2.36 \mathrm{E}-03$ \\
\hline Vantage & Muscle & Sr-90 & $7 / 17 / 91$ & $1.65 \mathrm{E}-03$ & $2.48 \mathrm{E}-03$ & 2.69E-03 \\
\hline Vantage & Carcass & Sr-90 & $9 / 25 / 90$ & $3.50 \mathrm{E}-02$ & 5.79E-03 & 8.67E-03 \\
\hline Vantage & Carcass & Sr-90 & $9 / 25 / 90$ & $4.28 \mathrm{E}-02$ & $6.04 \mathrm{E}-03$ & $1.01 \mathrm{E}-02$ \\
\hline Vantage & Carcass & Sr-90 & $9 / 25 / 90$ & 3.77E-02 & $5.70 \mathrm{E}-03$ & $8.89 \mathrm{E}-03$ \\
\hline Vantage & Carcass & Sr-90 & $7 / 17 / 91$ & 5.72E-02 & 7.01E-03 & $.1 .29 \mathrm{E}-02$ \\
\hline Vantage & Carcass & Sr-90 & $7 / 17 / 91$ & $8.26 \mathrm{E}-02$ & 8.03E-03 & $1.71 \mathrm{E}-02$ \\
\hline Vantage & Carcass & Sr-90 & $7 / 17 / 91$ & $5.06 \mathrm{E}-02$ & $6.80 \mathrm{E}-03$ & $1.17 \mathrm{E}-02$ \\
\hline
\end{tabular}

- indicates the analytical error exceeds the result (counting error is used when the analytical error is not reported) 
Table A.2. Radionuclide Concentrations in Carp, 1990-1992 (continued)

\begin{tabular}{|c|c|c|c|c|c|c|}
\hline Location & Tissue & $\underline{\text { Radionuclide }}$ & $\begin{array}{c}\text { Date } \\
(\mathrm{M} / \mathrm{D} / \mathrm{Y})\end{array}$ & $\begin{array}{c}\text { Concentration } \\
\text { (pCi/g wet) }\end{array}$ & $\begin{array}{l}\text { Counting } \\
\text { Error } \\
\text { (pCi/g wet) }\end{array}$ & $\begin{array}{c}\text { Propagated } \\
\text { Analytical } \\
\text { Error } \\
\text { (pCi/g wet) }\end{array}$ \\
\hline Vantage & Carcass & Sr-90 & $7 / 17 / 91$ & $5.06 \mathrm{E}-02$ & $7.04 \mathrm{E}-03$ & $1.17 \mathrm{E}-02$ \\
\hline Vantage & Carcass & Sr-90 & $7 / 17 / 91$ & 3.82E-02 & 8.13E-03 & $1.08 \mathrm{E}-02$ \\
\hline Vantage & Carcass & Sr-90 & $7 / 17 / 91$ & $9.62 \mathrm{E}-02$ & $1.20 \mathrm{E}-02$ & 2.13E-02 \\
\hline Vantage & Carcass & Sr -90 & $7 / 17 / 91$ & $3.58 \mathrm{E}-02$ & $5.04 \mathrm{E}-03$ & $9.54 \mathrm{E}-03$ \\
\hline Vantage. & Carcass & Sr-90 & $7 / 17 / 91$ & $6.00 \mathrm{E}-02$ & $5.88 \mathrm{E}-03$ & $1.27 \mathrm{E}-02$ \\
\hline Vantage & Carcass & Sr-90 & $7 / 17 / 91$ & $6.95 \mathrm{E}-02$ & $7.16 \mathrm{E}-03$ & $1.46 \mathrm{E}-02$ \\
\hline Vantage & Carcass & Sr-90 & $7 / 17 / 91$ & $1.08 \mathrm{E}-01$ & 9.39E-03 & 2.24E-02 \\
\hline Vantage & Muscle & U-234 & $7 / 17 / 91$ & $3.92 \mathrm{E}-03$ & $1.95 \mathrm{E}-03$ & 2.02E-03 \\
\hline Vantage & Muscle & $\mathrm{U}-234$ & $7 / 17 / 91$ & $1.61 \mathrm{E}-03$ & $1.77 E-03$ & $1.81 \mathrm{E}-03$ \\
\hline Vantage & Muscle & U-234 & $7 / 17 / 91$ & $1.12 \mathrm{E}-03$ & $1.40 \mathrm{E}-03$ & $1.44 \mathrm{E}-03$ \\
\hline Vantage & Muscle & U-234 & $7 / 17 / 91$ & 2.83E-03 & $1.68 \mathrm{E}-03$ & $1.74 \mathrm{E}-03$ \\
\hline Vantage & Muscle & U-234 & $7 / 17 / 91$ & $1.62 \mathrm{E}-03$ & $1.40 \mathrm{E}-03$ & $1.45 \mathrm{E}-03$ \\
\hline Vantage & Muscle & $\mathrm{U}-234$ & $7 / 17 / 91$ & 8.84E-04 & $1.18 \mathrm{E}-03$ & $1.21 \mathrm{E}-03$ \\
\hline Vantage & Muscle & U-234 & $7 / 17 / 91$ & $1.18 \mathrm{E}-04$ & 8.74E-04 & $9.16 \mathrm{E}-04$ \\
\hline Vantage & Muscle & U-234 & $7 / 17 / 91$ & $-9.99 E-05$ & $1.40 \mathrm{E}-03$ & $1.43 \mathrm{E}-03$ \\
\hline Vantage & Muscle & U-234 & $7 / 17 / 91$ & 4.88E-04 & $1.14 \mathrm{E}-03$ & $1.18 \mathrm{E}-03$ \\
\hline Vantage & Muscle & U-234 & $7 / 17 / 91$ & $2.93 \mathrm{E}-03$ & $1.39 \mathrm{E}-03$ & $1.45 \mathrm{E}-03$ \\
\hline Vantage & Muscle & $\mathrm{U}-235$ & $7 / 17 / 91$ & $5.46 \mathrm{E}-05$ & $6.81 \mathrm{E}-04$ & $6.86 \mathrm{E}-04$ \\
\hline Vantage & Muscle & U-235 & $7 / 17 / 91$ & 7.22E-04 & $9.65 \mathrm{E}-04$ & $9.72 E-04$ \\
\hline Vantage & Muscle & U-235 & $7 / 17 / 91$ & 4.38E-06 & $4.68 \mathrm{E}-04$ & 4.76E-04 \\
\hline Vantage & Muscle & U-235 & $7 / 17 / 91$ & 6.65E-05 & $3.74 \mathrm{E}-04$ & 3.83E-04 \\
\hline Vantage & Muscle & U-235 & $7 / 17 / 91$ & $4.06 \mathrm{E}-04$ & $6.88 \mathrm{E}-04$ & $6.95 \mathrm{E}-04$ \\
\hline Vantage & Muscle & U-235 & $7 / 17 / 91$ & $1.87 \mathrm{E}-04$ & 5.72E-04 & $5.76 \mathrm{E}-04$ \\
\hline Vantage & Muscle & U-235 & $7 / 17 / 91$ & $5.58 \mathrm{E}-04$ & $7.30 \mathrm{E}-04$ & 7.36E-04 \\
\hline Vantage & Muscle & U-235 & $7 / 17 / 91$ & $2.16 \mathrm{E}-04$ & $9.08 \mathrm{E}-04$ & 9.12E-04 \\
\hline Vantage & Muscle & U-235 & $7 / 17 / 91$ & $-4.37 \mathrm{E}-04$ & $2.91 E-04$ & 3.02E-04 \\
\hline Vantage & Muscle & U-235 & $7 / 17 / 91$ & $-6.80 \mathrm{E}-05$ & $2.89 E-04$ & $2.96 E-04$ \\
\hline Vantage & Muscle & U-238 & $7 / 17 / 91$ & 2.91E-03 & $1.52 \mathrm{E}-03$ & $1.56 \mathrm{E}-03$ \\
\hline Vantage & Muscle & $\mathrm{U}-238$ & $7 / 17 / 91$ & 1.59E-03 & $1.43 \mathrm{E}-03$ & $1.46 \mathrm{E}-03$ \\
\hline Vantage & Muscle & U-238 & $7 / 17 / 91$ & $7.40 \mathrm{E}-04$ & $1.20 \mathrm{E}-03$ & $1.22 \mathrm{E}-03$ \\
\hline Vantage & Muscle & $U-238$ & $7 / 17 / 91$ & $6.70 \mathrm{E}-04$ & $1.02 \mathrm{E}-03$ & $1.04 \mathrm{E}-03$ \\
\hline Vantage & Muscle & U-238 & $7 / 17 / 91$ & $1.33 \mathrm{E}-03$ & $1.24 \mathrm{E}-03$ & $1.26 \mathrm{E}-03$ \\
\hline Vantage & Muscle & $U-238$ & $7 / 17 / 91$ & 8.80E-05 & 7.57E-04 & $7.71 E-04$ \\
\hline Vantage & Muscle & U-238 & $7 / 17 / 91$ & 1.69E-03 & $1.26 \mathrm{E}-03$ & $1.28 \mathrm{E}-03$ \\
\hline Vantage & Muscle & U-238 & $7 / 17 / 91$ & 8.82E-04 & $1.32 \mathrm{E}-03$ & 1.33E-03 \\
\hline Vantage & Muscle & U-238 & $7 / 17 / 91$ & $1.56 \mathrm{E}-03$ & $1.13 \mathrm{E}-03$ & $1.15 \mathrm{E}-03$ \\
\hline Vantage & Muscle & U-238 & $7 / 17 / 91$ & $2.35 \mathrm{E}-03$ & $1.19 \mathrm{E}-03$ & $1.22 \mathrm{E}-03$ \\
\hline
\end{tabular}

- indicates the analytical error exceeds the result (counting error is used when the analytical error is not reported) 
Table A.3. Radionuclide Concentrations in Whitefish, 1982-1992 (continued)

\begin{tabular}{|c|c|c|c|c|c|c|}
\hline Location & Tissue & Radionuclide & $\begin{array}{c}\text { Date } \\
(\mathrm{M} / \mathrm{D} / \mathrm{Y})\end{array}$ & $\begin{array}{l}\text { Concentration } \\
\text { (pCi/g wet) }\end{array}$ & $\begin{array}{l}\text { Counting } \\
\text { Error } \\
\text { (pCi/g wet) }\end{array}$ & $\begin{array}{l}\text { Analytical } \\
\text { Error } \\
\text { (pCi/g wet) }\end{array}$ \\
\hline $100 \mathrm{D}$ & $\overline{\text { Carcass }}$ & Co-60 & $3 / 23 / 83$ & $1.95 \mathrm{E}-02$ & $1.89 \mathrm{E}-02$ & Not reported \\
\hline $100 \mathrm{D}$ & Carcass & $\mathrm{Co}-60$ & $4 / 1 / 83$ & $2.65 \mathrm{E}-02$ & 1.77E-02 & Not reported \\
\hline $100 \mathrm{D}$ & Carcass & Co-60 & $4 / 1 / 83$ & $2.65 \mathrm{E}-02$ & $1.77 \mathrm{E}-02$ & Not reported \\
\hline $100 \mathrm{D}$ & Carcass & Co-60 & $4 / 5 / 83$ & $6.26 \mathrm{E}-03$ & $1.40 \mathrm{E}-02$ & Not reported \\
\hline $100 \mathrm{D}$ & Carcass & Co-60 & $4 / 5 / 83$ & $1.61 \mathrm{E}-02$ & 1.59E-02 & Not reported \\
\hline $100 \mathrm{D}$ & Carcass & Cs-137 & $3 / 23 / 83$ & $-1.00 \mathrm{E}-02$ & $1.76 \mathrm{E}-02$ & Not reported \\
\hline $100 \mathrm{D}$ & Carcass & Cs- 137 & $4 / 1 / 83$ & $8.36 \mathrm{E}-03$ & $1.72 \mathrm{E}-02$ & Not reported \\
\hline $100 \mathrm{D}$ & Carcass & Cs- 137 & $4 / 1 / 83$ & $8.36 \mathrm{E}-03$ & $1.72 \mathrm{E}-02$ & Not reported \\
\hline $100 \mathrm{D}$ & Carcass & Cs- 137 & $4 / 5 / 83$ & $7.88 \mathrm{E}-03$ & $1.22 \mathrm{E}-02$ & Not reported \\
\hline $100 \mathrm{D}$ & Carcass & Cs-137 & $4 / 5 / 83$ & $1.86 \mathrm{E}-02$ & 8.38E-03 & Not reported \\
\hline $100 \mathrm{D}$ & Carcass & Sr-90 & $3 / 23 / 83$ & $1.21 \mathrm{E}-02$ & 5.19E-03 & Not reported \\
\hline $100 \mathrm{D}$ & Carcass & Sr-90 & $4 / 1 / 83$ & $2.31 \mathrm{E}-02$ & $3.04 \mathrm{E}-03$ & Not reported \\
\hline $100 \mathrm{D}$ & Carcass & Sr-90 & $4 / 1 / 83$ & $2.65 \mathrm{E}-02$ & $2.25 E-03$ & Not reported \\
\hline $100 \mathrm{D}$ & Carcass & Sr-90 & $4 / 5 / 83$ & $2.12 \mathrm{E}-02$ & 2.61E-03 & Not reported \\
\hline $100 \mathrm{D}$ & Carcass & Sr-90 & $4 / 5 / 83$ & $3.00 \mathrm{E}-02$ & 3.15E-03 & Not reported \\
\hline $100 \mathrm{D}$ & Carcass & $\mathrm{Sr}-90$ & $11 / 15 / 83$ & $-7.28 \mathrm{E}-03$ & $4.58 \mathrm{E}-03$ & Not reported \\
\hline $100 \mathrm{D}$ & Carcass & Sr-90 & $11 / 15 / 83$ & 3.70E-03 & 4.15E-03 & Not reported \\
\hline $100 \mathrm{D}$ & Carcass & Sr-90 & $11 / 28 / 83$ & 2.32E-02 & $9.64 E-03$ & Not reported \\
\hline $100 \mathrm{D}$ & Carcass & Sr-90 & $11 / 28 / 83$ & 2.50E-02 & 1.49E-02 & Not reported \\
\hline $100 \mathrm{D}$ & Carcass & Sr-90 & $11 / 28 / 83$ & $3.24 \mathrm{E}-02$ & $1.53 \mathrm{E}-02$ & Not reported \\
\hline $100 \mathrm{D}$ & Carcass & Sr-90 & $11 / 29 / 83$ & $5.98 \mathrm{E}-02$ & $2.12 \mathrm{E}-02$ & Not reported \\
\hline $100 \mathrm{D}$ & Carcass & Sr-90 & $11 / 29 / 83$ & 6.29E-02 & $1.34 \mathrm{E}-02$ & Not reported \\
\hline $100 \mathrm{D}$ & Carcass & Sr-90 & $12 / 2 / 83$ & 9.41E-03 & 4.79E-03 & Not reported \\
\hline $100 \mathrm{D}$ & Carcass & $\mathrm{Sr}-90$ & $12 / 2 / 83$ & 1.77E-02 & $3.15 \mathrm{E}-03$ & Not reported \\
\hline $100 \mathrm{D}$ & Carcass & Sr-90 & $11 / 30 / 84$ & 2.32E-02 & $5.22 \mathrm{E}-03$ & 6.89E-03 \\
\hline $100 \mathrm{D}$ & Carcass & Sr-90 & $11 / 30 / 84$ & $2.44 \mathrm{E}-02$ & 2.92E-03 & $5.56 \mathrm{E}-03$ \\
\hline $100 \mathrm{D}$ & Carcass & Sr-90 & $11 / 30 / 84$ & 2.83E-02 & 3.95E-03 & $6.75 \mathrm{E}-03$ \\
\hline $100 \mathrm{D}$ & Carcass & Sr-90 & $11 / 30 / 84$ & $2.84 \mathrm{E}-02$ & $2.31 \mathrm{E}-03$ & $5.96 \mathrm{E}-03$ \\
\hline $100 \mathrm{D}$ & Carcass & Sr-90 & $11 / 30 / 84$ & 3.37E-02 & $3.98 \mathrm{E}-03$ & $7.64 \mathrm{E}-03$ \\
\hline $100 \mathrm{D}$ & Carcass & Sr-90 & $12 / 12 / 84$ & 2.29E-02 & $3.68 \mathrm{E}-03$ & $5.76 \mathrm{E}-03$ \\
\hline $100 \mathrm{D}$ & Carcass & Sr-90 & $12 / 12 / 84$ & 2.63E-02 & $3.45 E-03$ & $6.15 \mathrm{E}-03$ \\
\hline $100 \mathrm{D}$ & Carcass & Sr-90 & $12 / 12 / 84$ & $3.42 \mathrm{E}-02$ & $3.28 \mathrm{E}-03$ & 7.39E-03 \\
\hline $100 \mathrm{D}$ & Carcass & Sr-90 & $12 / 12 / 84$ & $4.50 \mathrm{E}-02$ & $6.83 \mathrm{E}-03$ & $1.11 \mathrm{E}-02$ \\
\hline $100 \mathrm{D}$ & Carcass & Sr-90 & $12 / 12 / 84$ & $.7 .39 \mathrm{E}-02$ & $6.63 \mathrm{E}-03$ & $1.57 \mathrm{E}-02$ \\
\hline $100 \mathrm{D}$ & Carcạss & Sr-90 & $10 / 14 / 85$ & 4.29E-02 & 4.53E-03 & $9.46 \mathrm{E}-03$ \\
\hline $100 \mathrm{D}$ & Carcass & Sr-90 & $10 / 15 / 85$ & $5.15 \mathrm{E}-02$ & $5.38 \mathrm{E}-03$ & $1.13 \mathrm{E}-02$ \\
\hline $100 \mathrm{D}$ & Carcass & Sr-90 & $10 / 17 / 85$ & $2.54 \mathrm{E}-02$ & 5.21E-03 & 7.17E-03 \\
\hline $100 \mathrm{D}$ & Carcass & Sr-90 & $10 / 17 / 85$ & $5.10 \mathrm{E}-02$ & 2.92E-03 & $1.03 \mathrm{E}-02$ \\
\hline $100 \mathrm{D}$ & Carcass & Sr-90 & $10 / 17 / 85$ & $8.11 \mathrm{E}-02$ & 1.10E-02 & $1.92 \mathrm{E}-02$ \\
\hline $100 \mathrm{D}$ & Carcass & Sr-90 & $10 / 25 / 85$ & $3.65 \mathrm{E}-02$ & 4.20E-03 & 8.22E-03 \\
\hline $100 \mathrm{D}$ & Carcass & Sr-90 & $10 / 30 / 85$ & 4.18E-02 & 4.18E-03 & $9.10 \mathrm{E}-03$ \\
\hline $100 \mathrm{D}$ & Carcass & Sr-90 & $10 / 30 / 85$ & 4.28E-02 & $4.18 \mathrm{E}-03$ & $9.27 \mathrm{E}-03$ \\
\hline $100 \mathrm{D}$ & Carcass & Sr-90 & $10 / 31 / 85$ & $4.76 \mathrm{E}-02$ & $6.72 \mathrm{E}-03$ & $1.14 \mathrm{E}-02$ \\
\hline
\end{tabular}

- indicates the analytical error exceeds the result (counting error is used when the analytical error is not reported) 
Table A.3. Radionuclide Concentrations in Whitefish, 1982-1992 (continued)

\begin{tabular}{|c|c|c|c|c|c|c|}
\hline Location & Tissue & Radionuclide & $\begin{array}{c}\text { Date } \\
(\mathrm{M} / \mathrm{D} / \mathrm{Y})\end{array}$ & $\begin{array}{l}\text { Concentration } \\
\text { (pCi/g wet) }\end{array}$ & $\begin{array}{c}\text { Counting } \\
\text { Error } \\
\text { (pCi/g wet) }\end{array}$ & $\begin{array}{c}\text { Propagated } \\
\text { Analytical } \\
\text { Error } \\
\text { (pCi/g wet) }\end{array}$ \\
\hline $100 \mathrm{D}$ & Carcass & Sr-90 & $10 / 31 / 85$ & 8.47E-02 & $7.19 \mathrm{E}-03$ & $1.79 \mathrm{E}-02$ \\
\hline $100 \mathrm{D}$ & Carcass & Sr-90 & $10 / 1 / 86$ & $2.44 \mathrm{E}-02$ & $5.55 \mathrm{E}-03$ & $7.10 \mathrm{E}-03$ \\
\hline $100 \mathrm{D}$ & Carcass & Sr-90 & $10 / 1 / 86$ & $2.61 \mathrm{E}-02$ & $7.78 \mathrm{E}-03$ & $9.12 \mathrm{E}-03$ \\
\hline $100 \mathrm{D}$ & Carcass & Sr-90 & $10 / 1 / 86$ & 3.10E-02. & $9.65 \mathrm{E}-03$ & $1.12 \mathrm{E}-02$ \\
\hline $100 \mathrm{D}$ & Carcass & Sr-90 & $10 / 1 / 86$ & 3.70E-02 & $9.83 \mathrm{E}-03$ & $1.19 \mathrm{E}-02$ \\
\hline $100 \mathrm{D}$ & Carcass & Sr-90 & $10 / 1 / 86$ & 4.95E-02 & $7.41 \mathrm{E}-03$ & 1.17E-02 \\
\hline $100 \mathrm{D}$ & Carcass & Sr-90 & $10 / 2 / 86$ & 2.79E-02 & $6.05 \mathrm{E}-03$ & $7.85 \mathrm{E}-03$ \\
\hline $100 \mathrm{D}$ & Carcass & Sr-90 & $10 / 2 / 86$ & $2.90 \mathrm{E}-02$ & $4.43 \mathrm{E}-03$ & $7.24 \mathrm{E}-03$ \\
\hline $100 \mathrm{D}$ & Carcass & Sr-90 & $10 / 3 / 86$ & $2.74 \mathrm{E}-02$ & $6.59 \mathrm{E}-03$ & 8.22E-03 \\
\hline $100 \mathrm{D}$ & Carcass & Sr-90 & $10 / 3 / 86$ & $3.14 \mathrm{E}-02$ & $9.08 \mathrm{E}-03$ & 1.07E-02 \\
\hline $100 \mathrm{D}$ & Carcass & Sr-90 & $10 / 3 / 86$ & $1.06 \mathrm{E}-01$ & $1.19 \mathrm{E}-02$ & $2.24 \mathrm{E}-02$ \\
\hline $100 \mathrm{D}$ & Carcass & Sr-90 & $9 / 28 / 87$ & $1.55 \mathrm{E}-02$ & $4.69 \mathrm{E}-03$ & $6.24 \mathrm{E}-03$ \\
\hline $100 \mathrm{D}$ & Carcass & Sr-90 & $9 / 28 / 87$ & $1.63 \mathrm{E}-02$ & $4.92 \mathrm{E}-03$ & $6.55 \mathrm{E}-03$ \\
\hline $100 \mathrm{D}$ & Carcass & Sr-90 & $9 / 28 / 87$ & $1.90 \mathrm{E}-02$ & $4.88 \mathrm{E}-03$ & 7.01E-03 \\
\hline $100 \mathrm{D}$ & Carcass & Sr-90 & $9 / 28 / 87$ & $2.00 \mathrm{E}-02$ & 5.31E-03 & $7.48 \mathrm{E}-03$ \\
\hline $100 \mathrm{D}$ & Carcass & Sr-90 & $9 / 28 / 87$ & 2.12E-02 & $4.52 \mathrm{E}-03$ & 7.12E-03 \\
\hline $100 \mathrm{D}$ & Carcass & Sr-90 & $9 / 28 / 87$ & 2.17E-02 & $5.30 \mathrm{E}-03$ & $7.82 \mathrm{E}-03$ \\
\hline $100 \mathrm{D}$ & Carcass & Sr-90 & $9 / 28 / 87$ & $2.69 \mathrm{E}-02$ & 7.24E-03 & $1.00 \mathrm{E}-02$ \\
\hline $100 \mathrm{D}$ & Carcass & Sr-90 & $9 / 28 / 87$ & 2.72E-02 & $5.69 \mathrm{E}-03$ & $8.97 \mathrm{E}-03$ \\
\hline $100 \mathrm{D}$ & Carcass & Sr-90 & $9 / 28 / 87$ & $3.44 \mathrm{E}-02$ & 8.78E-03 & 1.24E-02 \\
\hline $100 \mathrm{D}$ & Carcass & Sr-90 & $9 / 28 / 87$ & 3.51E-02 & 5.47E-03 & $1.04 \mathrm{E}-02$ \\
\hline $100 \mathrm{D}$ & Carcass & Sr-90 & $9 / 28 / 88$ & 1.64E-02 & 3.33E-03 & 4.65E-03 \\
\hline $100 \mathrm{D}$ & Carcass & Sr-90 & $9 / 28 / 88$ & $2.64 \mathrm{E}-02$ & $5.01 \mathrm{E}-03$ & 7.22E-03 \\
\hline $100 \mathrm{D}$ & Carcass & Sr-90 & $9 / 28 / 88$ & $6.35 \mathrm{E}-02$ & 5.32E-03 & 1.30E-02 \\
\hline $100 \mathrm{D}$ & Carcass & Sr-90 & $9 / 29 / 88$ & 2.29E-02 & $5.72 \mathrm{E}-03$ & 7.39E-03 \\
\hline $100 \mathrm{D}$ & Carcass & Sr-90 & $9 / 29 / 88$ & $2.38 \mathrm{E}-02$ & 4.80E-03 & 6.64E-03 \\
\hline $100 \mathrm{D}$ & Carcass & Sr -90 & $9 / 30 / 88$ & $1.52 \mathrm{E}-02$ & $4.52 \mathrm{E}-03$ & 5.52E-03 \\
\hline $100 \mathrm{D}$ & Carcass & Sr-90 & $9 / 30 / 88$ & 2.17E-02 & 5.30E-03 & 6.81E-03 \\
\hline $100 \mathrm{D}$ & Carcass & Sr-90 & $9 / 30 / 88$ & $3.14 \mathrm{E}-02$ & 4.73E-03 & 7.67E-03 \\
\hline $100 \mathrm{D}$ & Carcass & Sr-90 & $10 / 28 / 88$ & $1.94 \mathrm{E}-02$ & 3.62E-03 & 5.21E-03 \\
\hline $100 \mathrm{D}$ & Carcass & Sr-90 & $10 / 31 / 88$ & 2.12E-02 & $3.76 \mathrm{E}-03$ & $5.51 \mathrm{E}-03$ \\
\hline $100 \mathrm{D}$ & Carcass & Sr-90 & $11 / 27 / 89$ & 7.73E-03 & $3.90 \mathrm{E}-03$ & $4.26 \mathrm{E}-03$ \\
\hline $100 \mathrm{D}$ & Carcass & Sr-90 & $11 / 27 / 89$ & $1.25 \mathrm{E}-02$ & 4.62E-03 & $5.25 \mathrm{E}-03$ \\
\hline $100 \mathrm{D}$ & Carcass & Sr-90 & $11 / 27 / 89$ & $1.76 \mathrm{E}-02$ & $5.78 \mathrm{E}-03$ & $6.71 \mathrm{E}-03$ \\
\hline $100 \mathrm{D}$ & Carcass & Sr-90 & $12 / 22 / 89$ & 1.29E-02 & $2.56 \mathrm{E}-03$ & $3.67 \mathrm{E}-03$ \\
\hline $100 \mathrm{D}$ & Carcass & Sr-90 & $12 / 22 / 89$ & $1.70 \mathrm{E}-02$ & $2.98 \mathrm{E}-03$ & $4.45 \mathrm{E}-03$ \\
\hline $100 \mathrm{D}$ & Carcass & Sr-90 & $12 / 22 / 89$ & $2.21 \mathrm{E}-02$ & $2.89 \mathrm{E}-03$ & $5.08 \mathrm{E}-03$ \\
\hline $100 \mathrm{D}$ & Carcass & Sr-90 & $11 / 22 / 91$ & $5.53 \mathrm{E}-03$ & 2.93E-03 & $3.24 \mathrm{E}-03$ \\
\hline $100 \mathrm{D}$ & Carcass & Sr-90 & $11 / 22 / 91$ & 5.95E-03 & $1.81 \mathrm{E}-03$ & 2.24E-03 \\
\hline $100 \mathrm{D}$ & Carcass & Sr-90 & $11 / 22 / 91$ & $9.21 \mathrm{E}-03$ & $2.86 \mathrm{E}-03$ & $3.39 \mathrm{E}-03$ \\
\hline $100 \mathrm{D}$ & Carcass & Sr-90 & $12 / 20 / 91$ & 3.23E-03 & $3.08 \mathrm{E}-03$ & 3.27E-03 \\
\hline $100 \mathrm{D}$ & Carcass & Sr-90 & $12 / 20 / 91$ & 1.79E-02 & $3.60 \mathrm{E}-03$ & $5.79 \mathrm{E}-03$ \\
\hline $100 \mathrm{D}$ & Muscle & Co-60 & $3 / 23 / 83$ & $8.28 \mathrm{E}-03$ & $1.66 \mathrm{E}-02$ & Not reported \\
\hline
\end{tabular}

* indicates the analytical error exceeds the result (counting error is used when the analytical error is not reported) 
Table A.3. Radionuclide Concentrations in Whitefish, 1982-1992 (continued)

\begin{tabular}{|c|c|c|c|c|c|c|c|}
\hline Location & Tissue & Radionuclide & $\begin{array}{c}\text { Date } \\
(\mathrm{M} / \mathrm{D} / \mathrm{Y})\end{array}$ & $\begin{array}{c}\text { Concentration } \\
\text { (pCi/g wet) }\end{array}$ & $\begin{array}{l}\text { Counting } \\
\text { Error } \\
\text { (pCi/g wet) }\end{array}$ & $\begin{array}{l}\text { Propagated } \\
\text { Analytical } \\
\text { Error } \\
\text { (pCi/g wet) }\end{array}$ & \\
\hline $100 \mathrm{D}$ & Muscle & Co-60 & $4 / 1 / 83$ & $-1.26 \mathrm{E}-01$ & $2.33 \mathrm{E}-01$ & Not reported & $*$ \\
\hline $100 \mathrm{D}$ & Muscle & Co-60 & $4 / 1 / 83$ & $6.71 \mathrm{E}-03$ & $1.51 \mathrm{E}-02$ & Not reported & * \\
\hline $100 \mathrm{D}$ & Muscle & Co-60 & $4 / 5 / 83$ & $1.19 \mathrm{E}-02$ & $1.42 \mathrm{E}-02$ & Not reported & * \\
\hline $100 \mathrm{D}$ & Muscle & Co-60 & $4 / 5 / 83$ & $1.70 \mathrm{E}-02$ & $1.37 \mathrm{E}-02$ & Not reported & \\
\hline $100 \mathrm{D}$ & Muscle & $\mathrm{Co}-60$ & $11 / 15 / 83$ & $6.75 \mathrm{E}-03$ & $1.63 \mathrm{E}-02$ & Not reported & * \\
\hline $100 \mathrm{D}$ & Muscle & Co-60 & $11 / 15 / 83$ & $7.50 \mathrm{E}-03$ & $1.90 \mathrm{E}-02$ & Not reported & * \\
\hline $100 \mathrm{D}$ & Muscle & $\mathrm{Co}-60$ & $11 / 28 / 83$ & $4.88 \mathrm{E}-03$ & $1.69 \mathrm{E}-02$ & Not reported & * \\
\hline $100 \mathrm{D}$ & Muscle & Co-60 & $11 / 28 / 83$ & $1.16 \mathrm{E}-02$ & $1.35 \mathrm{E}-02$ & Not reported & * \\
\hline $100 \mathrm{D}$ & Muscle & Co-60 & $11 / 28 / 83$ & $1.65 \mathrm{E}-02$ & $2.00 \mathrm{E}-02$ & Not reported & * \\
\hline $100 \mathrm{D}$ & Muscle & Co-60 & $11 / 29 / 83$ & $-9.56 \mathrm{E}-03$ & $1.71 \mathrm{E}-02$ & Not reported & * \\
\hline $100 \mathrm{D}$ & Muscle & Co- 60 & $11 / 29 / 83$ & $3.70 \mathrm{E}-02$ & 2.33E-02 & Not reported & \\
\hline $100 \mathrm{D}$ & Muscle & $\mathrm{Co}-60$ & $12 / 2 / 83$ & 4.90E-03 & $1.57 \mathrm{E}-02$ & Not reported & $*$ \\
\hline $100 \mathrm{D}$ & Muscle & $\mathrm{Co}-60$ & $12 / 2 / 83$ & $1.30 \mathrm{E}-02$ & $1.91 \mathrm{E}-02$ & Not reported & * \\
\hline $100 \mathrm{D}$ & Muscle & Co- 60 & $11 / 30 / 84$ & $2.56 \mathrm{E}-03$ & $1.61 \mathrm{E}-02$ & $1.61 \mathrm{E}-02$ & * \\
\hline $100 \mathrm{D}$ & Muscle & Co-60 & $11 / 30 / 84$ & $3.19 \mathrm{E}-03$ & $1.30 \mathrm{E}-02$ & $1.30 \mathrm{E}-02$ & $*$ \\
\hline $100 \mathrm{D}$ & Muscle & $\mathrm{Co}-60$ & $11 / 30 / 84$ & $1.49 \mathrm{E}-02$ & 1.37E-02 & $1.37 \mathrm{E}-02$ & \\
\hline $100 \mathrm{D}$ & Muscle & $\mathrm{Co}-60$ & $11 / 30 / 84$ & $1.91 \mathrm{E}-02$ & $1.43 \mathrm{E}-02$ & $1.43 \mathrm{E}-02$ & \\
\hline $100 \mathrm{D}$ & Muscle & Co-60 & $11 / 30 / 84$ & $6.25 \mathrm{E}-02$ & 4.73E-02 & 4.74E-02 & \\
\hline $100 \mathrm{D}$ & Muscle & $\mathrm{Co}-60$ & $12 / 12 / 84$ & $0.00 E+00$ & $0.00 \mathrm{E}+00$ & $0.00 \mathrm{E}+00$ & \\
\hline $100 \mathrm{D}$ & Muscle & $\mathrm{Co}-60$ & $12 / 12 / 84$ & $2.90 \mathrm{E}-03$ & $1.06 \mathrm{E}-02$ & $1.06 \mathrm{E}-02$ & $*$ \\
\hline $100 \mathrm{D}$ & Muscle & $\mathrm{Co}-60$ & $12 / 12 / 84$ & $1.50 \mathrm{E}-02$ & $1.38 \mathrm{E}-02$ & $1.38 \mathrm{E}-02$ & \\
\hline $100 \mathrm{D}$ & Muscle & Co-60 & $12 / 12 / 84$ & $1.50 \mathrm{E}-02$ & $1.55 \mathrm{E}-02$ & $1.55 \mathrm{E}-02$ & $*$ \\
\hline $100 \mathrm{D}$ & Muscle & Co-60 & $12 / 12 / 84$ & $1.60 \mathrm{E}-02$ & $1.04 \mathrm{E}-02$ & $1.05 \mathrm{E}-02$ & \\
\hline $100 \mathrm{D}$ & Muscle & Co-60 & $10 / 14 / 85$ & $-8.81 \mathrm{E}-03$ & 4.11E-02 & 4.11E-02 & $*$ \\
\hline $100 \mathrm{D}$ & Muscle & $\mathrm{Co}-60$ & $10 / 15 / 85$ & $9.51 \mathrm{E}-03$ & 2.59E-02 & $2.59 \mathrm{E}-02$ & $*$ \\
\hline $100 \mathrm{D}$ & Muscle & Co-60 & $10 / 17 / 85$ & $1.05 \mathrm{E}-03$ & 2.63E-02 & 2.63E-02 & * \\
\hline $100 \mathrm{D}$ & Muscle & Co-60 & $10 / 25 / 85$ & $-2.00 \mathrm{E}-02$ & 2.60E-02 & 2.61E-02 & * \\
\hline $100 \mathrm{D}$ & Muscle & Co-60 & $10 / 25 / 85$ & $1.30 \mathrm{E}-02$ & $3.57 \mathrm{E}-02$ & $3.57 \mathrm{E}-02$ & $*$ \\
\hline $100 \mathrm{D}$ & Muscle & Co-60 & $10 / 25 / 85$ & $5.76 \mathrm{E}-02$ & $2.88 \mathrm{E}-02$ & $2.90 \mathrm{E}-02$ & \\
\hline $100 \mathrm{D}$ & Muscle & Co-60 & $10 / 30 / 85$ & $-2.96 \mathrm{E}-02$ & $3.84 \mathrm{E}-02$ & $3.84 \mathrm{E}-02$ & $*$ \\
\hline $100 \mathrm{D}$ & Muscle & Co-60 & $10 / 30 / 85$ & $-7.17 \mathrm{E}-03$ & $2.29 E-02$ & 2.29E-02 & $*$ \\
\hline $100 \mathrm{D}$ & Muscle & $\mathrm{Co}-60$ & $10 / 31 / 85$ & $-2.60 \mathrm{E}-02$ & $3.66 \mathrm{E}-02$ & 3.67E-02 & $*$ \\
\hline $100 \mathrm{D}$ & Muscle & $\mathrm{Co}-60$ & $10 / 31 / 85$ & $2.83 E-02$ & $2.82 \mathrm{E}-02$ & $2.83 \mathrm{E}-02$ & \\
\hline $100 \mathrm{D}$ & Muscle & Co-60 & $10 / 1 / 86$ & $-1.02 \mathrm{E}-02$ & $2.80 \mathrm{E}-02$ & $2.80 \mathrm{E}-02$ & * \\
\hline $100 \mathrm{D}$ & Muscle & Co-60 & $10 / 1 / 86$ & 2.22E-03 & 2.13E-02 & $2.13 \mathrm{E}-02$ & $*$ \\
\hline $100 \mathrm{D}$ & Muscle & $\mathrm{Co}-60$ & $10 / 1 / 86$ & 3.73E-03 & 2.92E-02 & 2.92E-02 & * \\
\hline $100 \mathrm{D}$ & Muscle & Co-60 & $10 / 1 / 86$ & $1.11 \mathrm{E}-02$ & $1.95 E-02$ & $1.95 \mathrm{E}-02$ & * \\
\hline $100 \mathrm{D}$ & Muscle & Co-60 & $10 / 1 / 86$ & $1.80 \mathrm{E}-02$ & $2.73 \mathrm{E}-02$ & 2.73E-02 & * \\
\hline $100 \mathrm{D}$ & Muscle & Co-60 & $10 / 2 / 86$ & $-6.52 E-03$ & $3.04 \mathrm{E}-02$ & $3.04 \mathrm{E}-02$ & * \\
\hline $100 \mathrm{D}$ & Muscle & $\mathrm{Co}-60$ & $10 / 2 / 86$ & $3.22 \mathrm{E}-02$ & $1.72 \mathrm{E}-02$ & $1.75 \mathrm{E}-02$ & \\
\hline $100 \mathrm{D}$ & Muscle & Co-60 & $10 / 3 / 86$ & $-1.27 \mathrm{E}-02$ & $3.58 \mathrm{E}-02$ & $3.58 \mathrm{E}-02$ & * \\
\hline $100 \mathrm{D}$ & Muscle & Co-60 & $10 / 3 / 86$ & $3.36 \mathrm{E}-02$ & $3.89 \mathrm{E}-02$ & 3.91E-02 & * \\
\hline $100 \mathrm{D}$ & Muscle & Co-60 & $10 / 3 / 86$ & $4.41 \mathrm{E}-02$ & $2.58 \mathrm{E}-02$ & 2.62E-02 & \\
\hline
\end{tabular}

* indicates the analytical error exceeds the result (counting error is used when the analytical error is not reported) 
Table A.3. Radionuclide Concentrations in Whitefish, 1982-1992 (continued)

\begin{tabular}{|c|c|c|c|c|c|c|}
\hline Location & Tissue & Radionuclide & $\begin{array}{c}\text { Date } \\
(\mathrm{M} / \mathrm{D} / \mathrm{Y})\end{array}$ & $\begin{array}{l}\text { Concentration } \\
\text { (pCi/g wet) }\end{array}$ & $\begin{array}{l}\text { Counting } \\
\text { Error } \\
\text { (pCi/g wet) }\end{array}$ & $\begin{array}{l}\text { Propagated } \\
\text { Analytical } \\
\text { Error } \\
\text { (pCi/g wet) }\end{array}$ \\
\hline $100 \mathrm{D}$ & Muscle & Co- 60 & $9 / 28 / 87$ & $-2.54 \mathrm{E}-02$ & $3.70 \mathrm{E}-02$ & $3.70 \mathrm{E}-02$ \\
\hline $100 \mathrm{D}$ & Muscle & Co-60 & $9 / 28 / 87$ & $-1.51 E-02$ & 3.93E-02 & $3.94 \mathrm{E}-02$ \\
\hline $100 \mathrm{D}$ & Muscle & Co-60 & $9 / 28 / 87$ & $-1.13 E-02$ & $4.85 \mathrm{E}-02$ & $4.85 \mathrm{E}-02$ \\
\hline $100 \mathrm{D}$ & Muscle & Co-60 & $9 / 28 / 87$ & $-6.09 \mathrm{E}-03$ & $3.85 \mathrm{E}-02$ & $3.85 \mathrm{E}-02$ \\
\hline $100 \mathrm{D}$ & Muscle & Co-60 & $9 / 28 / 87$ & $4.58 \mathrm{E}-03$ & $2.59 \mathrm{E}-02$ & $2.59 \mathrm{E}-02$ \\
\hline $100 \mathrm{D}$ & Muscle & Co-60 & $9 / 28 / 87$ & $1.26 \mathrm{E}-02$ & $2.61 E-02$ & 2.61E-02 \\
\hline $100 \mathrm{D}$ & Muscle & Co-60 & $9 / 28 / 87$ & $1.66 \mathrm{E}-02$ & 5.01E-02 & $5.02 \mathrm{E}-02$ \\
\hline $100 \mathrm{D}$ & Muscle & Co-60 & $9 / 28 / 87$ & $3.29 \mathrm{E}-02$ & $3.32 \mathrm{E}-02$ & $3.33 \mathrm{E}-02$ \\
\hline $100 \mathrm{D}$ & Muscle & Co-60 & $9 / 28 / 87$ & 4.92E-02 & $2.39 E-02$ & $2.44 \mathrm{E}-02$ \\
\hline $100 \mathrm{D}$ & Muscle & Co-60 & $9 / 28 / 87$ & $5.30 \mathrm{E}-02$ & $3.49 \mathrm{E}-02$ & $3.53 \mathrm{E}-02$ \\
\hline $100 \mathrm{D}$ & Muscle & Co-60 & $9 / 28 / 88$ & $-9.32 \mathrm{E}-04$ & $1.64 \mathrm{E}-02$ & $1.64 \mathrm{E}-02$ \\
\hline $100 \mathrm{D}$ & Muscle & Co-60 & $9 / 28 / 88$ & 2.03E-02 & $1.64 \mathrm{E}-02$ & $1.66 \mathrm{E}-02$ \\
\hline $100 \mathrm{D}$ & Muscle & Co-60 & $9 / 28 / 88$ & 2.97E-02 & 1.97E-02 & $1.99 \mathrm{E}-02$ \\
\hline $100 \mathrm{D}$ & Muscle & Co-60 & $9 / 29 / 88$ & $5.36 \mathrm{E}-03$ & $1.55 \mathrm{E}-02$ & $1.55 \mathrm{E}-02$ \\
\hline $100 \mathrm{D}$ & Muscle & Co-60 & $9 / 29 / 88$ & $2.47 \mathrm{E}-02$ & $2.25 \mathrm{E}-02$ & 2.27E-02 \\
\hline $100 \mathrm{D}$ & Muscle & Co-60 & $9 / 30 / 88$ & 2.32E-03 & $3.85 \mathrm{E}-02$ & $3.85 \mathrm{E}-02$ \\
\hline $100 \mathrm{D}$ & Muscle & Co-60 & $9 / 30 / 88$ & $1.75 \mathrm{E}-02$ & $2.39 E-02$ & $2.40 \mathrm{E}-02$ \\
\hline $100 \mathrm{D}$ & Muscle & Co-60 & $9 / 30 / 88$ & 3.47E-02 & $2.55 \mathrm{E}-02$ & $2.57 \mathrm{E}-02$ \\
\hline $100 \mathrm{D}$ & Muscle & Co-60 & $10 / 28 / 88$ & 2.81E-02 & $3.88 \mathrm{E}-02$ & $3.89 \mathrm{E}-02$ \\
\hline $100 \mathrm{D}$ & Muscle & Co-60 & $10 / 31 / 88$ & $-3.38 \mathrm{E}-03$ & $1.95 \mathrm{E}-02$ & $1.95 \mathrm{E}-02$ \\
\hline $100 \mathrm{D}$ & Muscle & Co-60 & $11 / 27 / 89$ & $6.35 \mathrm{E}-03$ & $2.42 \mathrm{E}-02$ & 2.42E-02 \\
\hline $100 \mathrm{D}$ & Muscle & Co-60 & $11 / 27 / 89$ & 7.82E-03 & $2.11 \mathrm{E}-02$ & 2.11E-02 \\
\hline $100 \mathrm{D}$ & Muscle & Co-60 & $11 / 27 / 89$ & $1.73 \mathrm{E}-02$ & $1.51 \mathrm{E}-02$ & $1.52 \mathrm{E}-02$ \\
\hline $100 \mathrm{D}$ & Muscle & Co-60 & $12 / 22 / 89$ & $3.02 \mathrm{E}-03$ & $1.84 \mathrm{E}-02$ & $1.84 \mathrm{E}-02$ \\
\hline $100 \mathrm{D}$ & Muscle & Co-60 & $12 / 22 / 89$ & $5.30 \mathrm{E}-03$ & $1.63 \mathrm{E}-02$ & $1.63 \mathrm{E}-02$ \\
\hline $100 \mathrm{D}$ & Muscle & Co-60 & $12 / 22 / 89$ & $9.16 \mathrm{E}-03$ & $2.14 \mathrm{E}-02$ & $2.14 \mathrm{E}-02$ \\
\hline $100 \mathrm{D}$ & Muscle & Co-60 & $1 / 30 / 90$ & $6.52 \mathrm{E}-03$ & $5.25 \mathrm{E}-02$ & $5.25 \mathrm{E}-02$ \\
\hline $100 \mathrm{D}$ & Muscle & Co-60 & $1 / 30 / 90$ & $2.89 \mathrm{E}-02$ & $3.46 \mathrm{E}-02$ & $3.47 \mathrm{E}-02$ \\
\hline $100 \mathrm{D}$ & Muscle & Co-60 & $1 / 30 / 90$ & $3.07 \mathrm{E}-02$ & $4.49 \mathrm{E}-02$ & $4.50 \mathrm{E}-02$ \\
\hline $100 \mathrm{D}$ & Muscle & Co-60 & $1 / 30 / 90$ & $3.36 \mathrm{E}-02$ & $5.11 E-02$ & $5.12 \mathrm{E}-02$ \\
\hline $100 \mathrm{D}$ & Muscle & Co-60 & $1 / 30 / 90$ & $5.85 \mathrm{E}-02$ & $3.01 E-02$ & 3.07E-02 \\
\hline $100 \mathrm{D}$ & Muscle & Co-60 & $10 / 12 / 90$ & $-3.05 E-02$ & $2.90 \mathrm{E}-02$ & $2.91 \mathrm{E}-02$ \\
\hline $100 \mathrm{D}$ & Muscle & Co-60 & $10 / 12 / 90$ & $-3.18 E-03$ & $4.45 \mathrm{E}-02$ & $4.45 \mathrm{E}-02$ \\
\hline $100 \mathrm{D}$ & Muscle & Co-60 & $10 / 12 / 90$ & $9.04 E-03$ & $2.85 \mathrm{E}-02$ & $2.85 \mathrm{E}-02$ \\
\hline $100 \mathrm{D}$ & Muscle & Co-60 & $10 / 12 / 90$ & 3.30E-02 & 4.55E-02 & $4.56 \mathrm{E}-02$ \\
\hline $100 \mathrm{D}$ & Muscle & Co-60 & $10 / 12 / 90$ & 4.72E-02 & $5.59 \mathrm{E}-02$ & $5.61 \mathrm{E}-02$ \\
\hline $100 \mathrm{D}$ & Muscle & Co-60 & $11 / 22 / 91$ & $-3.80 \mathrm{E}-02$ & $2.56 \mathrm{E}-02$ & 2.59E-02 \\
\hline $100 \mathrm{D}$ & Muscle & Co-60 & $11 / 22 / 91$ & $-1.66 \mathrm{E}-02$ & $5.76 \mathrm{E}-02$ & $5.76 \mathrm{E}-02$ \\
\hline $100 \mathrm{D}$ & Muscle & $\mathrm{Co}-60$ & $11 / 22 / 91$ & $3.21 \mathrm{E}-02$ & $5.58 \mathrm{E}-02$ & 5.59E-02 \\
\hline $100 \mathrm{D}$ & Muscle & $\mathrm{Co}-60$ & $12 / 20 / 91$ & $-3.34 \mathrm{E}-03$ & $4.68 \mathrm{E}-02$ & $4.68 \mathrm{E}-02$ \\
\hline $100 \mathrm{D}$ & Muscle & $\mathrm{Co}-60$ & $12 / 20 / 91$ & $3.92 \mathrm{E}-02$ & $3.29 \mathrm{E}-02$ & $3.31 \mathrm{E}-02$ \\
\hline $100 \mathrm{D}$ & Muscle & Cs- 137 & $3 / 23 / 83$ & $1.16 \mathrm{E}-02$ & $1.37 \mathrm{E}-02$ & Not reported \\
\hline $100 \mathrm{D}$ & Muscle & Cs-137 & $4 / 1 / 83$ & $2.89 \mathrm{E}-02$ & $1.16 \mathrm{E}-02$ & Not reported \\
\hline
\end{tabular}

- indicates the analytical error exceeds the result (counting error is used when the analytical error is not reported) 
Table A.3. Radionuclide Concentrations in Whitefish, 1982-1992 (continued)

\begin{tabular}{|c|c|c|c|c|c|c|}
\hline Location & Tissue & $\underline{\text { Radionuclide }}$ & $\begin{array}{c}\text { Date } \\
(\mathrm{M} / \mathrm{D} / \mathrm{Y})\end{array}$ & $\begin{array}{l}\text { Concentration } \\
\text { (pCi/g wet) }\end{array}$ & $\begin{array}{l}\text { Counting } \\
\text { Error } \\
\text { (pCi/g wet) }\end{array}$ & $\begin{array}{l}\text { Propagated } \\
\text { Analytical } \\
\text { Error } \\
\text { (pCi/g wet) }\end{array}$ \\
\hline $100 \mathrm{D}$ & Muscle & Cs-137 & $4 / 1 / 83$ & $6.23 \mathrm{E}-02$ & $1.79 \mathrm{E}-01$ & Not reported \\
\hline $100 \mathrm{D}$ & Muscle & Cs-137 & $4 / 5 / 83$ & 5.99E-03 & $1.40 \mathrm{E}-02$ & Not reported \\
\hline $100 \mathrm{D}$ & Muscle & Cs-137 & $4 / 5 / 83$ & $8.44 \mathrm{E}-03$ & 1.19E-02 & Not reported \\
\hline $100 \mathrm{D}$ & Muscle & Cs-137 & $11 / 15 / 83$ & $1.87 \mathrm{E}-03$ & $1.48 \mathrm{E}-02$ & Not reported \\
\hline $100 \mathrm{D}$ & Muscle & Cs-137 & $11 / 15 / 83$ & $1.98 \mathrm{E}-02$ & $1.32 \mathrm{E}-02$ & Not reported \\
\hline $100 \mathrm{D}$ & Muscle & Cs-137 & $11 / 28 / 83$ & $2.30 \mathrm{E}-02$ & 8.65E-03 & Not reported \\
\hline $100 \mathrm{D}$ & Muscle & Cs-137 & $11 / 28 / 83$ & $2.76 \mathrm{E}-02$ & $1.48 \mathrm{E}-02$ & Not reported \\
\hline $100 \mathrm{D}$ & Muscle & Cs-137 & $11 / 28 / 83$ & $2.87 \mathrm{E}-02$ & $1.85 \mathrm{E}-02$ & Not reported \\
\hline $100 \mathrm{D}$ & Muscle & Cs-137 & $11 / 29 / 83$ & $2.81 \mathrm{E}-02$ & $1.12 \mathrm{E}-02$ & Not reported \\
\hline $100 \mathrm{D}$ & Muscle & Cs- 137 & $11 / 29 / 83$ & 3.27E-02 & $1.46 \mathrm{E}-02$ & Not reported \\
\hline $100 \mathrm{D}$ & Muscle & Cs- 137 & $12 / 2 / 83$ & $1.67 \mathrm{E}-02$ & $1.54 \mathrm{E}-02$ & Not reported \\
\hline $100 \mathrm{D}$ & Muscle & Cs-137 & $12 / 2 / 83$ & $2.54 \mathrm{E}-02$ & $1.40 \mathrm{E}-02$ & Not reported \\
\hline $100 \mathrm{D}$ & Muscle & Cs-137 & $11 / 30 / 84$ & $1.30 \mathrm{E}-02$ & $1.18 \mathrm{E}-02$ & $1.18 \mathrm{E}-02$ \\
\hline $100 \mathrm{D}$ & Muscle & Cs- 137 & $11 / 30 / 84$ & $1.47 \mathrm{E}-02$ & $1.26 \mathrm{E}-02$ & $1.26 \mathrm{E}-02$ \\
\hline $100 \mathrm{D}$ & Muscle & Cs-137 & $11 / 30 / 84$ & $2.57 \mathrm{E}-02$ & $6.09 \mathrm{E}-02$ & $6.09 E-02$ \\
\hline $100 \mathrm{D}$ & Muscle & Cs-137 & $11 / 30 / 84$ & $2.61 E-02$ & $1.46 \mathrm{E}-02$ & $1.47 \mathrm{E}-02$ \\
\hline $100 \mathrm{D}$ & Muscle & Cs-137 & $11 / 30 / 84$ & $2.70 \mathrm{E}-02$ & $1.27 \mathrm{E}-02$ & $1.28 \mathrm{E}-02$ \\
\hline $100 \mathrm{D}$ & Muscle & Cs- 137 & $12 / 12 / 84$ & $0.00 \mathrm{E}+00$ & $0.00 \mathrm{E}+00$ & $0.00 \mathrm{E}+00$ \\
\hline $100 \mathrm{D}$ & Muscle & Cs-137 & $12 / 12 / 84$ & $6.70 \mathrm{E}-03$ & $1.06 \mathrm{E}-02$ & $1.06 \mathrm{E}-02$ \\
\hline $100 \mathrm{D}$ & Muscle & Cs-137 & $12 / 12 / 84$ & $2.02 \mathrm{E}-02$ & $1.54 \mathrm{E}-02$ & $1.55 \mathrm{E}-02$ \\
\hline $100 \mathrm{D}$ & Muscle & Cs-137 & $12 / 12 / 84$ & $2.31 \mathrm{E}-02$ & $1.28 \mathrm{E}-02$ & $1.29 \mathrm{E}-02$ \\
\hline $100 \mathrm{D}$ & Muscle & Cs-137 & $12 / 12 / 84$ & $2.85 \mathrm{E}-02$ & $1.14 \mathrm{E}-02$ & 1.15E-02 \\
\hline $100 \mathrm{D}$ & Muscle & Cs-137 & $10 / 14 / 85$ & $4.80 \mathrm{E}-03$ & 4.27E-02 & 4.27E-02 \\
\hline $100 \mathrm{D}$ & Muscle & Cs-137 & $10 / 15 / 85$ & $4.70 \mathrm{E}-03$ & $2.47 \mathrm{E}-02$ & $2.47 \mathrm{E}-02$ \\
\hline $100 \mathrm{D}$ & Muscle & Cs-137 & $10 / 17 / 85$ & 4.24E-02 & 2.37E-02 & $2.38 \mathrm{E}-02$ \\
\hline $100 \mathrm{D}$ & Muscle & Cs-137 & $10 / 25 / 85$ & $-3.42 E-02$ & 4.86E-02 & 4.87E-02 \\
\hline $100 \mathrm{D}$ & Muscle & Cs-137 & $10 / 25 / 85$ & $2.99 \mathrm{E}-02$ & 2.47E-02 & $2.47 \mathrm{E}-02$ \\
\hline $100 \mathrm{D}$ & Muscle & Cs-137 & $10 / 25 / 85$ & $4.24 \mathrm{E}-02$ & $3.17 \mathrm{E}-02$ & $3.18 \mathrm{E}-02$ \\
\hline $100 \mathrm{D}$ & Muscle & Cs-137 & $10 / 30 / 85$ & $1.57 \mathrm{E}-02$ & 2.73E-02 & $2.73 E-02$ \\
\hline $100 \mathrm{D}$ & Muscle & Cs-137 & $10 / 30 / 85$ & 2.22E-02 & 3.63E-02 & 3.63E-02 \\
\hline $100 \mathrm{D}$ & Muscle & Cs-137 & $10 / 31 / 85$ & $1.05 \mathrm{E}-02$ & $2.95 \mathrm{E}-02$ & $2.95 \mathrm{E}-02$ \\
\hline $100 \mathrm{D}$ & Muscle & Cs-137 & $10 / 31 / 85$ & 2.42E-02 & 3.67E-02 & $3.67 E-02$ \\
\hline $100 \mathrm{D}$ & Muscle & Cs-137 & $10 / 1 / 86$ & $-2.71 E-03$ & $3.02 \mathrm{E}-02$ & $3.02 \mathrm{E}-02$ \\
\hline $100 \mathrm{D}$ & Muscle & Cs-137 & $10 / 1 / 86$ & $1.15 \mathrm{E}-02$ & 2.29E-02 & $2.30 \mathrm{E}-02$ \\
\hline $100 \mathrm{D}$ & Muscle & Cs- 137 & $10 / 1 / 86$ & $2.05 E-02$ & $3.23 \mathrm{E}-02$ & $3.23 E-02$ \\
\hline $100 \mathrm{D}$ & Muscle & Cs-137 & $10 / 1 / 86$ & $2.07 \mathrm{E}-02$ & $2.64 \mathrm{E}-02$ & $2.64 \mathrm{E}-02$ \\
\hline $100 \mathrm{D}$ & Muscle & Cs-137 & $10 / 1 / 86$ & $5.14 \mathrm{E}-02$ & $3.06 \mathrm{E}-02$ & $3.10 \mathrm{E}-02$ \\
\hline $100 \mathrm{D}$ & Muscle & $\mathrm{Cs}-137$ & $10 / 2 / 86$ & $1.08 \mathrm{E}-02$ & $3.14 \mathrm{E}-02$ & $3.14 \mathrm{E}-02$ \\
\hline $100 \mathrm{D}$ & Muscle & Cs -137 & $10 / 2 / 86$ & $2.18 \mathrm{E}-02$ & $2.50 \mathrm{E}-02$ & $2.51 E-02$ \\
\hline $100 \mathrm{D}$ & Muscle & Cs-1.37 & $10 / 3 / 86$ & $2.00 \mathrm{E}-02$ & 2.64E-02 & $2.65 E-02$ \\
\hline $100 \mathrm{D}$ & Muscle & Cs -137 & $10 / 3 / 86$ & $2.13 \mathrm{E}-02$ & $3.89 \mathrm{E}-02$ & $3.90 \mathrm{E}-02$ \\
\hline $100 \mathrm{D}$ & Muscle & Cs-137 & $10 / 3 / 86$ & $4.55 \mathrm{E}-02$ & 2.35E-02 & $2.40 \mathrm{E}-02$ \\
\hline $100 \mathrm{D}$ & Muscle & Cs-137 & $9 / 28 / 87$ & $-1.70 \mathrm{E}-02$ & $4.74 \mathrm{E}-02$ & $4.74 \mathrm{E}-02$ \\
\hline
\end{tabular}

- indicates the analytical error exceeds the result (counting error is used when the analytical error is not reported) 
Table A.3. Radionuclide Concentrations in Whitefish, 1982-1992 (continued)

\begin{tabular}{|c|c|c|c|c|c|c|c|}
\hline Location & Tissue & Radionuclide & $\begin{array}{c}\text { Date } \\
(\mathrm{M} / \mathrm{D} / \mathrm{Y})\end{array}$ & $\begin{array}{l}\text { Concentration } \\
\text { (pCi/g wet) }\end{array}$ & $\begin{array}{c}\text { Error } \\
\text { (pCi/g wet) }\end{array}$ & $\begin{array}{c}\text { Error } \\
\text { (pCi/g wet) }\end{array}$ & \\
\hline $100 \mathrm{D}$ & $\overline{\text { Muscle }}$ & Cs-137 & $9 / 28 / 87$ & $-1.66 \mathrm{E}-02$ & $3.82 \mathrm{E}-02$ & $3.82 \mathrm{E}-02$ & $*$ \\
\hline $100 \mathrm{D}$ & Muscle & Cs-137 & $9 / 28 / 87$ & $-8.53 \mathrm{E}-03$ & 3.69E-02 & $3.69 \mathrm{E}-02$ & $*$ \\
\hline $100 \mathrm{D}$ & Muscle & Cs-137 & $9 / 28 / 87$ & $1.80 \mathrm{E}-02$ & 2.64E-02 & $2.65 \mathrm{E}-02$ & * \\
\hline $100 \mathrm{D}$ & Muscle & Cs-137 & $9 / 28 / 87$ & 2.04E-02 & $3.70 \mathrm{E}-02$ & 3.70E-02 & $*$ \\
\hline $100 \mathrm{D}$ & Muscle & Cs-137 & $9 / 28 / 87$ & $2.86 \mathrm{E}-02$ & $2.47 \mathrm{E}-02$ & $2.48 \mathrm{E}-02$ & \\
\hline $100 \mathrm{D}$ & Muscle & Cs- 137 & $9 / 28 / 87$ & 3.14E-02 & 4.22E-02 & 4.23E-02 & * \\
\hline $100 \mathrm{D}$ & Muscle & Cs-137 & $9 / 28 / 87$ & $5.31 \mathrm{E}-02$ & 2.59E-02 & $2.64 \mathrm{E}-02$ & \\
\hline $100 \mathrm{D}$ & Muscle & Cs-137 & $9 / 28 / 87$ & $5.49 \mathrm{E}-02$ & 4.19E-02 & 4.22E-02 & \\
\hline $100 \mathrm{D}$ & Muscle & Cs-137 & $9 / 28 / 87$ & $5.64 \mathrm{E}-02$ & $3.13 \mathrm{E}-02$ & $3.18 \mathrm{E}-02$ & \\
\hline $100 \mathrm{D}$ & Muscle & Cs-137 & $9 / 28 / 88$ & $7.45 \mathrm{E}-03$ & $1.66 \mathrm{E}-02$ & $1.66 \mathrm{E}-02$ & $*$ \\
\hline $100 \mathrm{D}$ & Muscle & Cs-137 & $9 / 28 / 88$ & $3.53 \mathrm{E}-02$ & $1.42 \mathrm{E}-02$ & $1.46 \mathrm{E}-02$ & \\
\hline $100 \mathrm{D}$ & Muscle & Cs-137 & $9 / 28 / 88$ & $3.85 \mathrm{E}-02$ & $2.15 \mathrm{E}-02$ & $2.18 \mathrm{E}-02$ & \\
\hline $100 \mathrm{D}$ & Muscle & Cs-137 & $9 / 29 / 88$ & $1.60 \mathrm{E}-02$ & $2.14 \mathrm{E}-02$ & $2.15 \mathrm{E}-02$ & * \\
\hline $100 \mathrm{D}$ & Muscle & Cs-137 & $9 / 29 / 88$ & 2.37E-02 & $1.76 \mathrm{E}-02$ & $1.78 \mathrm{E}-02$ & . \\
\hline $100 \mathrm{D}$ & Muscle & Cs- 137 & $9 / 30 / 88$ & $7.69 \mathrm{E}-03$ & $2.30 \mathrm{E}-02$ & 2.30E-02 & $*$ \\
\hline $100 \mathrm{D}$ & Muscle & Cs- 137 & $9 / 30 / 88$ & $1.78 \mathrm{E}-02$ & 3.51E-02 & 3.52E-02 & $*$ \\
\hline $100 \mathrm{D}$ & Muscle & Cs-137 & $9 / 30 / 88$ & $3.38 \mathrm{E}-02$ & $1.80 \mathrm{E}-02$ & $1.84 \mathrm{E}-02$ & \\
\hline $100 \mathrm{D}$ & Muscle & Cs-137 & $10 / 28 / 88$ & $2.68 \mathrm{E}-02$ & $3.93 \mathrm{E}-02$ & $3.94 \mathrm{E}-02$ & * \\
\hline $100 \mathrm{D}$ & Muscle & Cs-137 & $10 / 31 / 88$ & $2.18 \mathrm{E}-02$ & $2.11 \mathrm{E}-02$ & $2.13 \mathrm{E}-02$ & \\
\hline $100 \mathrm{D}$ & Muscle & Cs-137 & $11 / 27 / 89$ & 1.32E-02 & $1.99 \mathrm{E}-02$ & $1.99 \mathrm{E}-02$ & * \\
\hline $100 \mathrm{D}$ & Muscle & Cs-137 & $11 / 27 / 89$ & 2.15E-02 & $1.40 \mathrm{E}-02$ & $1.42 \mathrm{E}-02$ & \\
\hline $100 \mathrm{D}$ & Muscle & Cs-137 & $11 / 27 / 89$ & 2.57E-02 & $1.85 \mathrm{E}-02$ & $1.87 \mathrm{E}-02$ & \\
\hline $100 \mathrm{D}$ & Muscle & Cs-137 & $12 / 22 / 89$ & $7.26 \mathrm{E}-03$ & $1.56 \mathrm{E}-02$ & $1.56 \mathrm{E}-02$ & * \\
\hline $100 \mathrm{D}$ & Muscle & Cs- 137 & $12 / 22 / 89$ & $8.26 \mathrm{E}-03$ & $1.66 \mathrm{E}-02$ & $1.66 \mathrm{E}-02$ & $*$ \\
\hline $100 \mathrm{D}$ & Muscle & Cs-137 & $12 / 22 / 89$ & $1.00 \mathrm{E}-02$ & $2.04 \mathrm{E}-02$ & 2.05E-02 & $*$ \\
\hline $100 \mathrm{D}$ & Muscle & Cs-137 & $1 / 30 / 90$ & $-9.06 E-03$ & 4.63E-02 & 4.63E-02 & $*$ \\
\hline $100 \mathrm{D}$ & Muscle & Cs-137 & $1 / 30 / 90$ & $-3.01 E-03$ & $3.25 \mathrm{E}-02$ & $3.25 \mathrm{E}-02$ & $*$ \\
\hline $100 \mathrm{D}$ & Muscle & Cs-137 & $1 / 30 / 90$ & $1.30 \mathrm{E}-02$ & $4.75 \mathrm{E}-02$ & 4.75E-02 & * \\
\hline $100 \mathrm{D}$ & Muscle & Cs-137 & $1 / 30 / 90$ & $2.37 \mathrm{E}-02$ & 2.99E-02 & $3.00 \mathrm{E}-02$ & $*$ \\
\hline $100 \mathrm{D}$ & Muscle & Cs-137 & $1 / 30 / 90$ & 2.49E-02 & 2.50E-02 & 2.51E-02 & * \\
\hline $100 \mathrm{D}$ & Muscle & Cs-137 & $10 / 12 / 90$ & $-4.30 \mathrm{E}-02$ & 4.77E-02 & 4.79E-02 & $*$ \\
\hline $100 \mathrm{D}$ & Muscle & Cs-137 & $10 / 12 / 90$ & $-1.88 \mathrm{E}-02$ & $4.60 \mathrm{E}-02$ & 4.61E-02 & * \\
\hline $100 \mathrm{D}$ & Muscle & Cs-137 & $10 / 12 / 90$ & 8.12E-04 & 2.48E-02 & $2.48 \mathrm{E}-02$ & * \\
\hline $100 \mathrm{D}$ & Muscle & Cs-137 & $10 / 12 / 90$ & $2.72 \mathrm{E}-02$ & 3.22E-02 & $3.24 \mathrm{E}-02$ & * \\
\hline $100 \mathrm{D}$ & Muscle & Cs-137 & $10 / 12 / 90$ & 5.30E-02 & $3.30 \mathrm{E}-02$ & $3.35 \mathrm{E}-02$ & \\
\hline $100 \mathrm{D}$ & Muscle & Cs-137 & $11 / 22 / 91$ & $5.17 \mathrm{E}-03$ & $5.24 \mathrm{E}-02$ & $5.24 \mathrm{E}-02$ & * \\
\hline $100 \mathrm{D}$ & Muscle & Cs-137 & $11 / 22 / 91$ & $2.44 \mathrm{E}-02$ & 4.82E-02 & $4.82 \mathrm{E}-02$ & * \\
\hline $100 \mathrm{D}$ & Muscle & Cs-137. & $11 / 22 / 91$ & $3.39 \mathrm{E}-02$ & $2.45 \mathrm{E}-02$ & $2.47 \mathrm{E}-02$ & \\
\hline $100 \mathrm{D}$ & Muscle & Cs- 137 & $12 / 20 / 91$ & $-1.66 \mathrm{E}-02$ & $4.06 \mathrm{E}-02$ & 4.07E-02 & * \\
\hline $100 \mathrm{D}$ & Muscle & Cs-137 & $12 / 20 / 91$ & $5.91 \mathrm{E}-02$ & $3.32 \mathrm{E}-02$ & 3.37E-02 & \\
\hline $100 \mathrm{D}$ & Muscle & Sr-90 & $3 / 23 / 83$ & $1.91 \mathrm{E}-03$ & 2.31E-03 & Not reported & * \\
\hline $100 \mathrm{D}$ & Muscle. & Sr-90 & $4 / 1 / 83$ & $0.00 \mathrm{E}+00$ & $1.96 \mathrm{E}-03$ & Not reported & $*$ \\
\hline $100 \mathrm{D}$ & Muscle & Sr-90 & $4 / 1 / 83$ & $3.50 \mathrm{E}-02$ & $4.54 \mathrm{E}-02$ & Not reported & * \\
\hline
\end{tabular}

- indicates the analytical error exceeds the result (counting error is used when the analytical error is not reported) 
Table A.3. Radionuclide Concentrations in Whitefish, 1982-1992 (continued)

\begin{tabular}{|c|c|c|c|c|c|c|}
\hline Location & Tissue & Radionuclide & $\begin{array}{c}\text { Date } \\
(\mathrm{M} / \mathrm{D} / \mathrm{Y})\end{array}$ & $\begin{array}{c}\text { Concentration } \\
\text { (pCi/g wet) }\end{array}$ & $\begin{array}{l}\text { Counting } \\
\text { Error } \\
\text { (pCi/g wet) }\end{array}$ & $\begin{array}{l}\text { Propagated } \\
\text { Analytical } \\
\text { Error } \\
\text { (pCi/g wet) }\end{array}$ \\
\hline $100 \mathrm{D}$ & Muscle & Sr-90 & $4 / 5 / 83$ & $-5.49 \mathrm{E}-04$ & $2.34 \mathrm{E}-03$ & Not reported \\
\hline $100 \mathrm{D}$ & Muscle & Sr-90 & $4 / 5 / 83$ & $2.56 \mathrm{E}-03$ & $1.84 \mathrm{E}-03$ & Not reported \\
\hline $100 \mathrm{D}$ & Muscle & Sr-90 & $11 / 15 / 83$ & $-7.83 E-03$ & $5.90 \mathrm{E}-03$ & Not reported \\
\hline $100 \mathrm{D}$ & Muscle & Sr-90 & $11 / 15 / 83$ & $-4.33 E-03$ & 7.22E-03 & Not reported \\
\hline $100 \mathrm{D}$ & Muscle & Sr-90 & $11 / 28 / 83$ & $-7.13 E-03$ & $5.26 \mathrm{E}-03$ & Not reported \\
\hline $100 \mathrm{D}$ & Muscle & Sr-90 & $11 / 28 / 83$ & $2.66 \mathrm{E}-03$ & $6.76 \mathrm{E}-03$ & Not reported \\
\hline $100 \mathrm{D}$ & Muscle & Sr-90 & $11 / 28 / 83$ & $3.85 E-03$ & $2.25 \mathrm{E}-03$ & Not reported \\
\hline $100 \mathrm{D}$ & Muscle & Sr-90 & $11 / 29 / 83$ & $-1.48 \mathrm{E}-02$ & $1.17 \mathrm{E}-02$ & Not reported \\
\hline $100 \mathrm{D}$ & Muscle & $\mathrm{Sr}-90$ & $11 / 29 / 83$ & $1.50 E-03$ & $4.05 \mathrm{E}-03$ & Not reported \\
\hline $100 \mathrm{D}$ & Muscle & Sr-90 & $12 / 2 / 83$ & $-6.22 \mathrm{E}-03$ & $4.26 \mathrm{E}-03$ & Not reported \\
\hline $100 \mathrm{D}$ & Muscle & Sr-90 & $12 / 2 / 83$ & $4.50 \mathrm{E}-03$ & $3.02 \mathrm{E}-03$ & Not reported \\
\hline $100 \cdot \mathrm{D}$ & Muscle & Sr-90 & $11 / 30 / 84$ & $3.35 E-03$ & $5.16 \mathrm{E}-03$ & $5.24 \mathrm{E}-03$ \\
\hline $100 \mathrm{D}$ & Muscle & Sr-90 & $11 / 30 / 84$ & $5.22 \mathrm{E}-03$ & $4.85 \mathrm{E}-03$ & 4.97E-03 \\
\hline $100 \mathrm{D}$ & Muscle & Sr-90 & $11 / 30 / 84$ & $6.77 \mathrm{E}-03$ & 4.03E-03 & $4.24 \mathrm{E}-03$ \\
\hline $100 \mathrm{D}$ & Muscle & Sr-90 & $11 / 30 / 84$ & $9.88 \mathrm{E}-03$ & $9.83 \mathrm{E}-03$ & $1.00 \mathrm{E}-02$ \\
\hline $100 \mathrm{D}$ & Muscle & Sr-90 & $11 / 30 / 84$ & 1.33E-02 & $1.03 \mathrm{E}-02$ & $1.06 \mathrm{E}-02$ \\
\hline $100 \mathrm{D}$ & Muscle & Sr-90 & $12 / 12 / 84$ & $3.05 E-03$ & $3.71 E-03$ & 3.77E-03 \\
\hline $100 \mathrm{D}$ & Muscle & Sr-90 & $12 / 12 / 84$ & $3.44 \mathrm{E}-03$ & 2.95E-03 & $3.03 \mathrm{E}-03$ \\
\hline $100 \mathrm{D}$ & Muscle. & Sr-90 & $12 / 12 / 84$ & $3.87 \mathrm{E}-03$ & $1.70 \mathrm{E}-03$ & $1.85 \mathrm{E}-03$ \\
\hline $100 \mathrm{D}$ & Muscle & Sr-90 & $12 / 12 / 84$ & $5.36 \mathrm{E}-03$ & $2.46 \mathrm{E}-03$ & 2.67E-03 \\
\hline $100 \mathrm{D}$ & Muscle & Sr-90 & $12 / 12 / 84$ & $6.20 \mathrm{E}-03$ & 2.92E-03 & $3.18 \mathrm{E}-03$ \\
\hline $100 \mathrm{D}$ & Muscle & Sr -90 & $10 / 14 / 85$ & $4.15 \mathrm{E}-03$ & $4.23 \mathrm{E}-03$ & 4.30E-03 \\
\hline $100 \mathrm{D}$ & Muscle & Sr-90 & $10 / 15 / 85$ & 3.37E-03 & $1.82 \mathrm{E}-03$ & $1.94 \mathrm{E}-03$ \\
\hline $100 \mathrm{D}$ & Muscle & Sr-90 & $10 / 17 / 85$ & $4.52 \mathrm{E}-03$ & $2.75 E-03$ & $2.89 \mathrm{E}-03$ \\
\hline $100 \mathrm{D}$ & Muscle & $\mathrm{Sr}-90$ & $10 / 25 / 85$ & $3.70 \mathrm{E}-03$ & $2.76 \mathrm{E}-03$ & $2.89 \mathrm{E}-03$ \\
\hline $100 \mathrm{D}$ & Muscle & Sr-90 & $10 / 25 / 85$ & $7.64 \mathrm{E}-03$ & $3.10 \mathrm{E}-03$ & 3.43E-03 \\
\hline $100 \mathrm{D}$ & Muscle & Sr-90 & $10 / 25 / 85$ & 7.77E-03 & 3.31E-03 & $3.64 \mathrm{E}-03$ \\
\hline $100 \mathrm{D}$ & Múscle & Sr-90 & $10 / 30 / 85$ & $5.09 \mathrm{E}-03$ & $2.36 \mathrm{E}-03$ & $2.56 \mathrm{E}-03$ \\
\hline $100 \mathrm{D}$ & Muscle & Sr-90 & $10 / 30 / 85$ & $6.85 \mathrm{E}-03$ & 2.49E-03 & $2.82 \mathrm{E}-03$ \\
\hline $100 \mathrm{D}$ & Muscle & Sr-90 & $10 / 31 / 85$ & 5.22E-03 & 2.17E-03 & $2.40 \mathrm{E}-03$ \\
\hline $100 \mathrm{D}$ & Muscle & Sr-90 & $10 / 31 / 85$ & $5.35 \mathrm{E}-03$ & $2.26 \mathrm{E}-03$ & $2.50 \mathrm{E}-03$ \\
\hline $100 \mathrm{D}$ & Muscle & Sr-90 & $10 / 1 / 86$ & $1.34 \mathrm{E}-03$ & $1.36 \mathrm{E}-03$ & $1.41 \mathrm{E}-03$ \\
\hline $100 \mathrm{D}$ & Muscle & Sr-90 & $10 / 1 / 86$ & $2.86 \mathrm{E}-03$ & $1.58 \mathrm{E}-03$ & $1.68 \mathrm{E}-03$ \\
\hline $100 \mathrm{D}$ & Muscle & Sr-90 & $10 / 1 / 86$ & 3.60E-03 & $1.73 E-03$ & $1.87 \mathrm{E}-03$ \\
\hline $100 \mathrm{D}$ & Muscle & Sr-90 & $10 / 1 / 86$ & 3.72E-03 & $1.69 \mathrm{E}-03$ & $1.90 \mathrm{E}-03$ \\
\hline $100 \mathrm{D}$ & Muscle & $\mathrm{Sr}-90$ & $10 / 1 / 86$ & 3.74E-03 & $1.55 \mathrm{E}-03$ & $1.72 \mathrm{E}-03$ \\
\hline $100 \mathrm{D}$ & Muscle & Sr-90 & $10 / 2 / 86$ & $1.58 \mathrm{E}-03$ & $1.13 \mathrm{E}-03$ & $1.18 \mathrm{E}-03$ \\
\hline $100 \mathrm{D}$ & Muscle & Sr-90 & $10 / 2 / 86$ & $2.54 \mathrm{E}-03$ & $1.96 \mathrm{E}-03$ & $2.02 \mathrm{E}-03$ \\
\hline $100 \mathrm{D}$ & Muscle & Sr-90 & $10 / 3 / 86$ & 2.07E-03 & $1.76 \mathrm{E}-03$ & $1.81 \mathrm{E}-03$ \\
\hline $100 \mathrm{D}$ & Muscle & Sr-90 & $10 / 3 / 86$ & 2.33E-03 & $1.32 \mathrm{E}-03$ & $1.40 \mathrm{E}-03$ \\
\hline $100 \mathrm{D}$ & Muscle & Sr-90 & $10 / 3 / 86$ & $3.71 \mathrm{E}-03$ & $2.03 E-03$ & $2.16 \mathrm{E}-03$ \\
\hline $100 \mathrm{D}$ & Muscle & Sr-90 & $9 / 28 / 87$ & $-6.05 E-04$ & $2.65 \mathrm{E}-03$ & 2.72E-03 \\
\hline $100 \mathrm{D}$ & Muscle & $\mathrm{Sr}-90$ & $9 / 28 / 87$ & $4.15 \mathrm{E}-04$ & $2.03 E-03$ & $2.16 \mathrm{E}-03$ \\
\hline
\end{tabular}

- indicates the analytical error exceeds the result (counting error is used when the analytical error is not reported) 
Table A.3. Radionuclide Concentrations in Whitefish, 1982-1992 (continued)

\begin{tabular}{|c|c|c|c|c|c|c|}
\hline Location & Tissue & Radionuclide & $\begin{array}{c}\text { Date } \\
(\mathrm{M} / \mathrm{D} / \mathrm{Y})\end{array}$ & $\begin{array}{l}\text { Concentration } \\
\text { (pCi/g wet) }\end{array}$ & $\begin{array}{l}\text { Counting } \\
\text { Error } \\
\text { (pCi/g wet) }\end{array}$ & $\begin{array}{l}\text { Propagated } \\
\text { Analytical } \\
\text { Error } \\
\text { (pCi/g wet) }\end{array}$ \\
\hline $100 \mathrm{D}$ & Muscle & Sr-90 & $9 / 28 / 87$ & $9.41 \mathrm{E}-04$ & $1.61 \mathrm{E}-03$ & $1.76 \mathrm{E}-03$ \\
\hline $100 \mathrm{D}$ & Muscle & Sr-90 & $9 / 28 / 87$ & $1.05 \mathrm{E}-03$ & $2.21 E-03$ & 2.39E-03 \\
\hline $100 \mathrm{D}$ & Muscle & Sr-90 & $9 / 28 / 87$ & $1.26 \mathrm{E}-03$ & $1.90 \mathrm{E}-03$ & $2.11 \mathrm{E}-03$ \\
\hline $100 \mathrm{D}$ & Muscle & Sr-90 & $9 / 28 / 87$ & $1.30 \mathrm{E}-03$ & $2.71 E-03$ & $2.85 \mathrm{E}-03$ \\
\hline $100 \mathrm{D}$ & Muscle & Sr-90 & $9 / 28 / 87$ & $1.60 \mathrm{E}-03$ & $2.68 \mathrm{E}-03$ & 2.84E-03 \\
\hline $100 \mathrm{D}$ & Muscle & Sr-90 & $9 / 28 / 87$ & $1.85 \mathrm{E}-03$ & $2.35 \mathrm{E}-03$ & 2.54E-03 \\
\hline $100 \mathrm{D}$ & Muscle & Sr-90 & $9 / 28 / 87$ & $2.22 \mathrm{E}-03$ & $1.96 \mathrm{E}-03$ & $2.21 \mathrm{E}-03$ \\
\hline $100 \mathrm{D}$ & Muscle & Sr-90 & $9 / 28 / 87$ & 4.37E-03 & $2.54 \mathrm{E}-03$ & 3.03E-03 \\
\hline $100 \mathrm{D}$ & Muscle & Sr-90 & $9 / 28 / 88$ & $-5.60 \mathrm{E}-04$ & $1.64 \mathrm{E}-03$ & $1.79 \mathrm{E}-03$ \\
\hline $100 \mathrm{D}$ & Muscle & Sr-90 & $9 / 28 / 88$ & $1.38 \mathrm{E}-03$ & $2.30 \mathrm{E}-03$ & $2.46 \mathrm{E}-03$ \\
\hline $100 \mathrm{D}$ & Muscle & Sr-90 & $9 / 28 / 88$ & $2.80 \mathrm{E}-03$ & $1.96 \mathrm{E}-03$ & 2.23E-03 \\
\hline $100 \mathrm{D}$ & Muscle & Sr-90 & $9 / 29 / 88$ & $-4.66 \mathrm{E}-04$ & $2.35 \mathrm{E}-03$ & $2.46 \mathrm{E}-03$ \\
\hline $100 \mathrm{D}$ & Muscle & Sr-90 & $9 / 29 / 88$ & $6.35 \mathrm{E}-05$ & $1.78 \mathrm{E}-03$ & $2.06 \mathrm{E}-03$ \\
\hline $100 \mathrm{D}$ & Muscle & Sr-90 & $9 / 30 / 88$ & $-7.00 \mathrm{E}-04$ & $2.45 \mathrm{E}-03$ & $2.82 \mathrm{E}-03$ \\
\hline $100 \mathrm{D}$ & Muscle & Sr-90 & $9 / 30 / 88$ & $-5.49 \mathrm{E}-04$ & $2.20 \mathrm{E}-03$ & $2.51 \mathrm{E}-03$ \\
\hline $100 \mathrm{D}$ & Muscle & $\mathrm{Sr}-90$ & $9 / 30 / 88$ & $1.97 \mathrm{E}-04$ & $2.24 \mathrm{E}-03$ & $2.55 \mathrm{E}-03$ \\
\hline $100 \mathrm{D}$ & Muscle & Sr-90 & $10 / 28 / 88$ & 4.66E-03 & $5.71 \mathrm{E}-03$ & $6.01 \mathrm{E}-03$ \\
\hline $100 \mathrm{D}$ & Muscle & Sr-90 & $10 / 31 / 88$ & $2.48 \mathrm{E}-03$ & $3.54 \mathrm{E}-03$ & $3.75 \mathrm{E}-03$ \\
\hline $100 \mathrm{D}$ & Muscle & Sr-90 & $11 / 27 / 89$ & 1.77E-03 & 2.36E-03 & $2.75 \mathrm{E}-03$ \\
\hline $100 \mathrm{D}$ & Muscle & Sr-90 & $11 / 27 / 89$ & $2.18 \mathrm{E}-03$ & $1.89 \mathrm{E}-03$ & $2.23 \mathrm{E}-03$ \\
\hline $100 \mathrm{D}$ & Muscle & Sr-90 & $11 / 27 / 89$ & 2.30E-03 & $4.28 \mathrm{E}-03$ & 4.90E-03 \\
\hline $100 \mathrm{D}$ & Muscle & $\mathrm{Sr}-90$ & $12 / 22 / 89$ & $5.50 \mathrm{E}-03$ & $2.51 \mathrm{E}-03$ & 3.03E-03 \\
\hline $100 \mathrm{D}$ & Muscle & Sr-90 & $12 / 22 / 89$ & $1.52 \mathrm{E}-02$ & $2.82 \mathrm{E}-03$ & $4.20 \mathrm{E}-03$ \\
\hline $100 \mathrm{D}$ & Muscle & Sr-90 & $12 / 22 / 89$ & $2.35 \mathrm{E}-02$ & $3.86 \mathrm{E}-03$ & $6.00 \mathrm{E}-03$ \\
\hline $100 \mathrm{D}$ & Muscle & Sr-90 & $1 / 30 / 90$ & 8.43E-04 & 2.77E-03 & 2.91E-03 \\
\hline $100 \mathrm{D}$ & Muscle & $\mathrm{Sr}-90$ & $1 / 30 / 90$ & $1.29 \mathrm{E}-03$ & $1.86 \mathrm{E}-03$ & $2.01 E-03$ \\
\hline $100 \mathrm{D}$ & Muscle & Sr-90 & $1 / 30 / 90$ & $1.43 \mathrm{E}-03$ & $2.99 \mathrm{E}-03$ & $3.21 \mathrm{E}-03$ \\
\hline $100 \mathrm{D}$ & Muscle & Sr-90 & $1 / 30 / 90$ & $1.83 \mathrm{E}-03$ & $1.98 \mathrm{E}-03$ & 2.18E-03 \\
\hline $100 \mathrm{D}$ & Muscle & Sr-90 & $1 / 30 / 90$ & $2.04 \mathrm{E}-03$ & 5.29E-03 & $5.46 \mathrm{E}-03$ \\
\hline $100 \mathrm{D}$ & Muscle & $\mathrm{Sr}-90$ & $10 / 12 / 90$ & $-2.69 \mathrm{E}-04$ & $3.13 \mathrm{E}-03$ & 3.39E-03 \\
\hline $100 \mathrm{D}$ & Muscle & Sr-90 & $10 / 12 / 90$ & $4.96 \mathrm{E}-04$ & $1.76 \mathrm{E}-03$ & $1.88 \mathrm{E}-03$ \\
\hline $100 \mathrm{D}$ & Muscle & Sr-90 & $10 / 12 / 90$ & $1.21 \mathrm{E}-03$ & $2.69 \mathrm{E}-03$ & $2.87 \mathrm{E}-03$ \\
\hline $100 \mathrm{D}$ & Muscle & Sr-90 & $10 / 12 / 90$ & $1.66 \mathrm{E}-03$ & 4.69E-03 & $4.86 \mathrm{E}-03$ \\
\hline $100 \mathrm{D}$ & Muscle & Sr-90 & $10 / 12 / 90$ & 2.62E-03 & $2.57 \mathrm{E}-03$ & $2.82 E-03$ \\
\hline $100 \mathrm{D}$ & Muscle & Sr-90 & $11 / 22 / 91$ & 4.27E-05 & $7.45 \mathrm{E}-03$ & 7.57E-03 \\
\hline $100 \mathrm{D}$ & Muscle & $\mathrm{Sr}-90$ & $11 / 22 / 91$ & 2.61E-04 & 2.99E-03 & $3.23 E-03$ \\
\hline $100 \mathrm{D}$ & Muscle & Sr-90 & $11 / 22 / 91$ & 1.27E-03 & 7.73E-03 & 7.82E-03 \\
\hline $100 \mathrm{D}$ & Muscle & Sr-90 & $12 / 20 / 91$ & $-3.76 E-04$ & 2.07E-03 & $2.21 E-03$ \\
\hline $100 \mathrm{D}$ & Muscle & Sr-90 & $12 / 20 / 91$ & $6.65 \mathrm{E}-04$ & $1.96 \mathrm{E}-03$ & 2.12E-03 \\
\hline $100 \mathrm{~N}$ & Carcass & Sr-90 & $11 / 13 / 90$ & 1.19E-02 & $3.64 \mathrm{E}-03$ & $4.36 \mathrm{E}-03$ \\
\hline $100 N$ & Carcass & Sr-90 & $11 / 15 / 90$ & 8.04E-03 & 2.68E-03 & $3.18 \mathrm{E}-03$ \\
\hline $100 N$ & Carcass & Sr-90 & $11 / 15 / 90$ & $9.15 \mathrm{E}-03$ & $3.48 \mathrm{E}-03$ & $3.96 \mathrm{E}-03$ \\
\hline $100 \mathrm{~N}$ & Carcass & Sr-90 & $11 / 15 / 90$ & 9.99E-03 & 3.70E-03 & 4.24E-03 \\
\hline
\end{tabular}

* indicates the analytical error exceeds the result (counting error is used when the analytical error is not reported) 
Table A.3. Radionuclide Concentrations in Whitefish, 1982-1992 (continued)

\begin{tabular}{|c|c|c|c|c|c|c|}
\hline Location & Tissue & $\underline{\text { Radionuclide }}$ & $\begin{array}{c}\text { Date } \\
(\mathrm{M} / \mathrm{D} / \mathrm{Y})\end{array}$ & $\begin{array}{c}\text { Concentration } \\
\text { (pCi/g wet) }\end{array}$ & $\begin{array}{l}\text { Counting } \\
\text { Error } \\
\text { (pCi/g wet) }\end{array}$ & $\begin{array}{c}\text { Propagated } \\
\text { Analytical } \\
\text { Error } \\
\text { (pCi/g wet) }\end{array}$ \\
\hline $100 N$ & Carcass & Sr-90 & $11 / 15 / 90$ & $1.11 \mathrm{E}-02$ & $3.55 \mathrm{E}-03$ & $4.23 \mathrm{E}-03$ \\
\hline $100 \mathrm{~N}$ & Carcass & Sr-90 & $11 / 17 / 92$ & 8.63E-03 & 2.77E-03 & 3.37E-03 \\
\hline $100 \mathrm{~N}$ & Carcass & Sr-90 & $11 / 17 / 92$ & $9.96 \mathrm{E}-03$ & 2.75E-03 & $3.43 E-03$ \\
\hline $100 \mathrm{~N}$ & Carcass & Sr-90 & $11 / 17 / 92$ & $1.00 \mathrm{E}-02$ & 3.69E-03 & $4.25 \mathrm{E}-03$ \\
\hline $100 \mathrm{~N}$ & Carcass & Sr-90 & $11 / 17 / 92$ & $1.01 E-02$ & $2.92 \mathrm{E}-03$ & $3.55 \mathrm{E}-03$ \\
\hline $100 \mathrm{~N}$ & Carcass & Sr-90 & $11 / 17 / 92$ & $1.03 \mathrm{E}-02$ & $2.81 \mathrm{E}-03$ & $3.51 \mathrm{E}-03$ \\
\hline $100 \mathrm{~N}$ & Carcass & Sr-90 & $11 / 17 / 92$ & $1.27 \mathrm{E}-02$ & 3.01E-03 & $3.98 E-03$ \\
\hline $100 \mathrm{~N}$ & Carcass & Sr-90 & $11 / 17 / 92$ & $1.28 \mathrm{E}-02$ & $3.64 \mathrm{E}-03$ & $4.49 \mathrm{E}-03$ \\
\hline $100 \mathrm{~N}$ & Carcass & Sr-90 & $11 / 17 / 92$ & $1.41 \mathrm{E}-02$ & $2.78 \mathrm{E}-03$ & $3.96 \mathrm{E}-03$ \\
\hline $100 \mathrm{~N}$ & Carcass & Sr-90 & $11 / 17 / 92$ & $3.23 \mathrm{E}-02$ & 4.57E-03 & 7.34E-03 \\
\hline $100 \mathrm{~N}$ & Muscle & Co-60 & $11 / 13 / 90$ & 3.13E-02 & $3.80 \mathrm{E}-02$ & $3.81 \mathrm{E}-02$ \\
\hline $100 \mathrm{~N}$ & Muscle & $\mathrm{Co}-60$ & $11 / 15 / 90$ & $-2.35 \mathrm{E}-02$ & $5.08 \mathrm{E}-02$ & $5.09 \mathrm{E}-02$ \\
\hline $100 \mathrm{~N}$ & Muscle & Co-60 & $11 / 15 / 90$ & $7.25 \mathrm{E}-03$ & $4.70 \mathrm{E}-02$ & $4.70 \mathrm{E}-02$ \\
\hline $100 \mathrm{~N}$ & Muscle & $\mathrm{Co}-60$ & $11 / 15 / 90$ & $1.23 E-02$ & $3.88 \mathrm{E}-02$ & $3.88 \mathrm{E}-02$ \\
\hline $100 \mathrm{~N}$ & Muscle & Co- 60 & $11 / 15 / 90$ & $3.43 \mathrm{E}-02$ & $3.17 \mathrm{E}-02$ & $3.19 E-02$ \\
\hline $100 \mathrm{~N}$ & Muscle & Co-60 & $11 / 17 / 92$ & $-6.66 \mathrm{E}-03$ & 2.31E-02 & $2.31 \mathrm{E}-02$ \\
\hline $100 \mathrm{~N}$ & Muscle & Co-60 & $11 / 17 / 92$ & $-6.37 \mathrm{E}-03$ & $2.38 \mathrm{E}-02$ & 2.38E-02 \\
\hline $100 \mathrm{~N}$ & Muscle & Co- 60 & $11 / 17 / 92$ & $-4.99 E-03$ & $3.28 \mathrm{E}-02$ & $3.28 \mathrm{E}-02$ \\
\hline $100 \mathrm{~N}$ & Muscle & Co-60 & $11 / 17 / 92$ & $-1.67 \mathrm{E}-03$ & $1.75 \mathrm{E}-02$ & $1.75 \mathrm{E}-02$ \\
\hline $100 \mathrm{~N}$ & Muscle & Co-60 & $11 / 17 / 92$ & $3.36 \mathrm{E}-03$ & $1.59 \mathrm{E}-02$ & $1.59 \mathrm{E}-02$ \\
\hline $100 \mathrm{~N}$ & Muscle & Co-60 & $11 / 17 / 92$ & $3.51 \mathrm{E}-03$ & 2.38E-02 & $2.38 \mathrm{E}-02$ \\
\hline $100 \mathrm{~N}$ & Muscle & Co- 60 & $11 / 17 / 92$ & $7.11 \mathrm{E}-03$ & $2.60 \mathrm{E}-02$ & $2.60 \mathrm{E}-02$ \\
\hline $100 \mathrm{~N}$ & Muscle & Co-60 & $11 / 17 / 92$ & 1.01E-02 & $2.17 \mathrm{E}-02$ & 2.17E-02 \\
\hline $100 N$ & Muscle & Co-60 & $11 / 17 / 92$ & $: \quad 1.65 \mathrm{E}-02$ & 2.13E-02 & $2.14 \mathrm{E}-02$ \\
\hline $100 \mathrm{~N}$ & Muscle & $\mathrm{Co}-60$ & $11 / 17 / 92$ & 1.95E-02 & $1.64 \mathrm{E}-02$ & $1.65 \mathrm{E}-02$ \\
\hline $100^{\circ} \mathrm{N}$ & Muscle & Cs-137 & $11 / 13 / 90$ & $-2.43 E-02$ & 4.35E-02 & 4.36E-02 \\
\hline $100 \mathrm{~N}$ & Muscle & Cs-137 & $11 / 15 / 90$ & $-1.16 \mathrm{E}-02$ & $4.75 \mathrm{E}-02$ & $4.75 \mathrm{E}-02$ \\
\hline $100 \mathrm{~N}$ & Muscle & Cs-137 & $11 / 15 / 90$ & $1.31 \mathrm{E}-02$ & $3.68 \mathrm{E}-02$ & $3.68 \mathrm{E}-02$ \\
\hline $100 \mathrm{~N}$ & Muscle & Cs-137 & $11 / 15 / 90$ & $1.71 \mathrm{E}-02$ & 4.18E-02 & $4.18 \mathrm{E}-02$ \\
\hline $100 \mathrm{~N}$ & Muscle & Cs-137 & $11 / 15 / 90$ & 2.89E-02 & 3.95E-02 & $3.96 \mathrm{E}-02$ \\
\hline $100 \mathrm{~N}$ & Muscle & Cs-137 & $11 / 17 / 92$ & $7.54 \mathrm{E}-03$ & $1.78 \mathrm{E}-02$ & $1.78 \mathrm{E}-02$ \\
\hline $100 \mathrm{~N}$ & Muscle & Cs-137 & $11 / 17 / 92$ & 8.63E-03 & $1.76 \mathrm{E}-02$ & $1.76 \mathrm{E}-02$ \\
\hline $100 \mathrm{~N}$ & Muscle & Cs-137 & $11 / 17 / 92$ & $1.20 \mathrm{E}-02$ & $1.77 \mathrm{E}-02$ & $1.77 \mathrm{E}-02$ \\
\hline $100 \mathrm{~N}$ & Muscle & Cs-137 & $11 / 17 / 92$ & $2.71 \mathrm{E}-02$ & $2.53 \mathrm{E}-02$ & $2.54 \mathrm{E}-02$ \\
\hline $100 \mathrm{~N}$ & Muscle & Cs-137 & $11 / 17 / 92$ & 2.81E-02 & 2.07E-02 & 2.09E-02 \\
\hline $100 \mathrm{~N}$ & Muscle & Cs-137 & $11 / 17 / 92$ & $2.92 \mathrm{E}-02$ & $2.42 \mathrm{E}-02$ & 2.43E-02 \\
\hline $100 \mathrm{~N}$ & Muscle & Cs-137 & $11 / 17 / 92$ & $3.43 \mathrm{E}-02$ & $1.95 \mathrm{E}-02$ & $1.98 \mathrm{E}-02$ \\
\hline $100 \mathrm{~N}$ & Muscle & Cs-137 & $11 / 17 / 92$ & $4.08 \mathrm{E}-02$ & $1.85 \mathrm{E}-02$ & $1.89 \mathrm{E}-02$ \\
\hline $100 \mathrm{~N}$ & Muscle & Cs-137 & $11 / 17 / 92$ & $6.50 \mathrm{E}-02$ & $2.10 \mathrm{E}-02$ & $2.20 \mathrm{E}-02$ \\
\hline $100 \mathrm{~N}$ & Muscle & Cs- 137 & $11 / 17 / 92$ & $1.69 \mathrm{E}-01$ & $3.09 \mathrm{E}-02$ & $3.52 E-02$ \\
\hline $100 \mathrm{~N}$ & Muscle & $\mathrm{Sr}-90$ & $11 / 13 / 90$ & $1.15 \mathrm{E}-03$ & $2.25 \mathrm{E}-03$ & $2.45 \mathrm{E}-03$ \\
\hline $100 \mathrm{~N}$ & Muscle & Sr-90 & $11 / 15 / 90$ & $4.09 \mathrm{E}-05$ & $2.31 \mathrm{E}-03$ & $2.48 \mathrm{E}-03$ \\
\hline $100 \mathrm{~N}$ & Muscle & $\mathrm{Sr}-90$ & $11 / 15 / 90$ & 3.99E-04 & 2.34E-03 & 2.53E-03 \\
\hline
\end{tabular}

* indicates the analytical error exceeds the result (counting error is used when the analytical error is not reported) 
Table A.3. Radionuclide Concentrations in Whitefish, 198.2-1992 (continued)

\begin{tabular}{|c|c|c|c|c|c|c|}
\hline Location & Tissue & Radionuclide & $\begin{array}{c}\text { Date } \\
(\mathrm{M} / \mathrm{D} / \mathrm{Y})\end{array}$ & $\begin{array}{c}\text { Concentration } \\
\text { (pCi/g wet) }\end{array}$ & $\begin{array}{c}\text { Error } \\
\text { (pCi/g wet) }\end{array}$ & $\begin{array}{c}\text { Error } \\
\text { (pCi/g wet) }\end{array}$ \\
\hline $100 \mathrm{~N}$ & Muscle & Sr-90 & $11 / 15 / 90$ & $1.70 \mathrm{E}-03$ & $2.97 \mathrm{E}-03$ & $3.11 \mathrm{E}-03$ \\
\hline $100 \mathrm{~N}$ & Muscle & Sr-90 & $11 / 15 / 90$ & $2.65 \mathrm{E}-03$ & 2.83E-03 & $3.01 E-03$ \\
\hline $100 \mathrm{~N}$ & Muscle & Sr-90 & $11 / 17 / 92$ & $-2.43 E-03$ & $5.14 \mathrm{E}-03$ & $5.28 \mathrm{E}-03$ \\
\hline $100 \mathrm{~N}$ & Muscle & Sr-90 & $11 / 17 / 92$ & $-2.39 E-03$ & 4.08E-03 & 4.29E-03 \\
\hline $100 N$ & Muscle & Sr-90 & $11 / 17 / 92$ & $2.34 \mathrm{E}-03$ & $6.53 \mathrm{E}-03$ & $6.62 \mathrm{E}-03$ \\
\hline $300 \mathrm{~A}$ & Carcass & Sr-90 & $11 / 1 / 90$ & $8.81 \mathrm{E}-03$ & $3.53 \mathrm{E}-03$ & 4.03E-03 \\
\hline $300 \mathrm{~A}$ & Carcass & Sr-90 & $11 / 2 / 90$ & $7.99 \mathrm{E}-03$ & 4.70E-03 & $5.04 \mathrm{E}-03$ \\
\hline $300 \mathrm{~A}$ & Carcass & Sr-90 & $11 / 2 / 90$ & 8.48E-03 & $2.48 \mathrm{E}-03$ & $3.06 \mathrm{E}-03$ \\
\hline $300 \mathrm{~A}$ & Carcass & Sr-90 & $11 / 2 / 90$ & $1.38 \mathrm{E}-02$ & $3.76 \mathrm{E}-03$ & $4.60 \mathrm{E}-03$ \\
\hline $300 \mathrm{~A}$ & Carcass & Sr-90 & $11 / 2 / 90$ & $1.87 \mathrm{E}-02$ & $4.34 \mathrm{E}-03$ & $5.53 \mathrm{E}-03$ \\
\hline $300 \mathrm{~A}$ & Carcass & Sr-90 & $12 / 19 / 91$ & $5.65 \mathrm{E}-03$ & $3.64 \mathrm{E}-03$ & 3.97E-03 \\
\hline $300 \mathrm{~A}$ & Carcass & Sr-90 & $12 / 19 / 91$ & $8.04 \mathrm{E}-03$ & $3.16 \mathrm{E}-03$ & $3.85 \mathrm{E}-03$ \\
\hline $300 \mathrm{~A}$ & Carcass & Sr-90 & $12 / 17 / 92$ & $5.05 \mathrm{E}-03$ & 2.85E-03. & $3.11 \mathrm{E}-03$ \\
\hline $300 \mathrm{~A}$ & Carcass & Sr-90 & $12 / 17 / 92$ & $5.95 \mathrm{E}-03$ & $3.60 \mathrm{E}-03$ & $3.91 \mathrm{E}-03$ \\
\hline $300 \mathrm{~A}$ & Carcass & Sr-90 & $12 / 17 / 92$ & $7.35 \mathrm{E}-03$ & $4.05 \mathrm{E}-03$ & $4.50 \mathrm{E}-03$ \\
\hline $300 \mathrm{~A}$ & Carcass & Sr-90 & $12 / 17 / 92$ & $1.04 \mathrm{E}-02$ & 5.20E-03 & $5.78 \mathrm{E}-03$ \\
\hline $300 \mathrm{~A}$ & Carcass & Sr-90 & $12 / 17 / 92$ & $1.16 \mathrm{E}-02$ & $4.62 \mathrm{E}-03$ & 5.53E-03 \\
\hline $300 \mathrm{~A}$ & Carcass & Sr-90 & $12 / 17 / 92$ & $1.50 \mathrm{E}-02$ & $4.55 \mathrm{E}-03$ & $5.55 \mathrm{E}-03$ \\
\hline $300 \mathrm{~A}$ & Carcass & Sr-90 & $12 / 17 / 92$ & $1.64 \mathrm{E}-02$ & 4.32E-03 & 5.34E-03 \\
\hline $300 \mathrm{~A}$ & Carcass & Sr-90 & $12 / 17 / 92$ & $1.96 \mathrm{E}-02$ & 3.17E-03 & $5.69 \mathrm{E}-03$ \\
\hline $300 \mathrm{~A}$ & Carcass & Sr-90 & $12 / 17 / 92$ & $2.28 \mathrm{E}-02$ & $3.62 \mathrm{E}-03$ & $6.79 \mathrm{E}-03$ \\
\hline $300 \mathrm{~A}$ & Carcass & Sr-90 & $12 / 17 / 92$ & $2.34 \mathrm{E}-02$ & $4.90 \mathrm{E}-03$ & $6.69 E-03$ \\
\hline $300 \mathrm{~A}$ & Muscle & Co-60 & $11 / 1 / 90$ & $1.04 \mathrm{E}-03$ & 4.13E-02 & 4.13E-02 \\
\hline $300 \mathrm{~A}$ & Muscle & Co-60. & $11 / 2 / 90$ & $-8.26 \mathrm{E}-03$ & 4.05E-02 & $4.05 \mathrm{E}-02$ \\
\hline $300 \mathrm{~A}$ & Muscle & Co-60 & $11 / 2 / 90$ & $-5.34 \mathrm{E}-03$ & 4.62E-02 & $4.62 \mathrm{E}-02$ \\
\hline $300 \mathrm{~A}$ & Muscle & Co-60 & $11 / 2 / 90$ & $1.99 \mathrm{E}-03$ & $4.74 \mathrm{E}-02$ & 4.74E-02 \\
\hline $300 \mathrm{~A}$ & Muscle & Co-60 & $11 / 2 / 90$ & 1.19E-02 & $6.55 \mathrm{E}-02$ & $6.55 \mathrm{E}-02$ \\
\hline $300 \mathrm{~A}$ & Muscle & Co-60 & $12 / 19 / 91$ & $-2.21 E-03$ & $3.10 \mathrm{E}-02$ & $3.10 \mathrm{E}-02$ \\
\hline $300 \mathrm{~A}$ & Muscle & Co-60 & $12 / 19 / 91$ & $5.65 \mathrm{E}-02$ & $5.01 \mathrm{E}-02$ & $.5 .04 \mathrm{E}-02$ \\
\hline $300 \mathrm{~A}$ & Muscle & Co-60 & $12 / 17 / 92$ & $-2.26 \mathrm{E}-02$ & $2.61 \mathrm{E}-02$ & $2.62 \mathrm{E}-02$ \\
\hline $300 \mathrm{~A}$ & Muscle & Co-60 & $12 / 17 / 92$ & $-6.52 E-03$ & $1.45 \mathrm{E}-02$ & $1.45 \mathrm{E}-02$ \\
\hline $300 \mathrm{~A}$ & Muscle & Co- 60 & $12 / 17 / 92$ & $-4.23 E-03$ & $1.96 \mathrm{E}-02$ & $1.96 \mathrm{E}-02$ \\
\hline $300 \mathrm{~A}$ & Muscle & Co-60 & $12 / 17 / 92$ & $4.66 \mathrm{E}-03$ & $2.01 \mathrm{E}-02$ & 2.01E-02 \\
\hline $300 \mathrm{~A}$ & Muscle & Co-60 & $12 / 17 / 92$ & $5.28 \mathrm{E}-03$ & 2.07E-02 & $2.07 \mathrm{E}-02$ \\
\hline $300 \mathrm{~A}$ & Muscle & Co-60 & $12 / 17 / 92$ & $5.80 \mathrm{E}-03$ & $1.81 \mathrm{E}-02$ & $1.81 \mathrm{E}-02$ \\
\hline $300 \mathrm{~A}$ & Muscle & Co-60 & $12 / 17 / 92$ & $6.07 \mathrm{E}-03$ & $1.86 \mathrm{E}-02$ & $1.86 \mathrm{E}-02$ \\
\hline $300 \mathrm{~A}$ & Muscle & Co-60 & $12 / 17 / 92$ & 7.31E-03 & 2.79E-02 & $2.79 \mathrm{E}-02$ \\
\hline $300 \mathrm{~A}$ & Muscle & Co-60 & $12 / 17 / 92$ & $1.17 \mathrm{E}-02$ & $1.64 \mathrm{E}-02$ & $1.64 \mathrm{E}-02$ \\
\hline $300 \mathrm{~A}$ & Muscle & Co-60 & $12 / 17 / 92$ & $1.50 \mathrm{E}-02$ & $1.72 \mathrm{E}-02$ & $1.73 E-02$ \\
\hline $300 \mathrm{~A}$ & Muscle & Cs-137 & $11 / 1 / 90$ & $3.04 \mathrm{E}-02$ & 3.39E-02 & $3.41 \mathrm{E}-02$ \\
\hline $300 \mathrm{~A}$ & Muscle & Cs- 137 & $11 / 2 / 90$ & $-8.60 \mathrm{E}-03$ & $4.22 \mathrm{E}-02$ & 4.22E-02 \\
\hline $300 \mathrm{~A}$ & Muscle & Cs-137 & $11 / 2 / 90$ & $9.32 \mathrm{E}-03$ & $3.95 \mathrm{E}-02$ & $3.95 \mathrm{E}-02$ \\
\hline $300 \mathrm{~A}$ & Muscle & Cs-137 & $11 / 2 / 90$ & $2.47 \mathrm{E}-02$ & $4.63 E-02$ & $4.63 \mathrm{E}-02$ \\
\hline
\end{tabular}

- indicates the analytical error exceeds the result (counting error is used when the analytical error is not reported) 
Table A.3. Radionuclide Concentrations in Whitefish, 1982-1992 (continued)

\begin{tabular}{|c|c|c|c|c|c|c|}
\hline Location & Tissue & Radionuclide & $\begin{array}{c}\text { Date } \\
\text { (M/D/Y) }\end{array}$ & $\begin{array}{c}\text { Concentration } \\
\text { (pCi/g wet) }\end{array}$ & $\begin{array}{l}\text { Counting } \\
\text { Error } \\
\text { (pCi/g wet) }\end{array}$ & $\begin{array}{c}\text { Propagated } \\
\text { Analytical } \\
\text { Error } \\
\text { (pCi/g wet) }\end{array}$ \\
\hline $300 \mathrm{~A}$ & $\overline{\text { Muscle }}$ & Cs-137 & $11 / 2 / 90$ & $3.76 \mathrm{E}-02$ & $4.31 \mathrm{E}-02$ & $4.33 \mathrm{E}-02$ \\
\hline $300 \mathrm{~A}$ & Muscle & Cs- 137 & $12 / 19 / 91$ & $-7.11 \mathrm{E}-04$ & 2.82E-02 & $2.82 \mathrm{E}-02$ \\
\hline $300 \mathrm{~A}$ & Muscle & Cs- 137 & $12 / 19 / 91$ & $9.39 \mathrm{E}-03$ & $4.25 \mathrm{E}-02$ & 4.25E-02 \\
\hline $300 \mathrm{~A}$ & Muscle & Cs -137 & $12 / 17 / 92$ & $-5.00 \mathrm{E}-03$ & $1.90 \mathrm{E}-02$ & 1.91E-02 \\
\hline $300 \mathrm{~A}$ & Muscle & Cs- 137 & $12 / 17 / 92$ & $2.10 \mathrm{E}-03$ & $2.60 \mathrm{E}-02$ & $2.60 \mathrm{E}-02$ \\
\hline $300 \mathrm{~A}$ & Muscle & Cs- 137 & $12 / 17 / 92$ & $3.53 E-03$ & $1.38 \mathrm{E}-02$ & $1.38 \mathrm{E}-02$ \\
\hline $300 \mathrm{~A}$ & Muscle & Cs- 137 & $12 / 17 / 92$ & $4.92 E-03$ & $1.80 \mathrm{E}-02$ & $1.80 \mathrm{E}-02$ \\
\hline $300 \mathrm{~A}$ & Muscle & Cs-137 & $12 / 17 / 92$ & $5.20 \mathrm{E}-03$ & $1.72 \mathrm{E}-02$ & $1.72 \mathrm{E}-02$ \\
\hline $300 \mathrm{~A}$ & Muscle & Cs- 137 & $12 / 17 / 92$ & $1.64 \mathrm{E}-02$ & $1.75 \mathrm{E}-02$ & $1.76 \mathrm{E}-02$ \\
\hline $300 \mathrm{~A}$ & Muscle & Cs- 137 & $12 / 17 / 92$ & $1.64 \mathrm{E}-02$ & $1.88 \mathrm{E}-02$ & $1.89 \mathrm{E}-02$ \\
\hline $300 \mathrm{~A}$ & Muscle & Cs-137 & $12 / 17 / 92$ & $2.47 \mathrm{E}-02$ & $1.44 \mathrm{E}-02$ & $1.46 \mathrm{E}-02$ \\
\hline $300 \mathrm{~A}$ & Muscle & Cs-137 & $12 / 17 / 92$ & $2.47 \mathrm{E}-02$ & 2.22E-02 & 2.23E-02 \\
\hline $300 \mathrm{~A}$ & Muscle & Cs- 137 & $12 / 17 / 92$ & $2.73 E-02$ & $1.68 \mathrm{E}-02$ & $1.70 \mathrm{E}-02$ \\
\hline $300 \mathrm{~A}$ & Muscle & Sr-90 & $11 / 1 / 90$ & $9.46 \mathrm{E}-04$ & $1.93 \mathrm{E}-03$ & 2.09E-03 \\
\hline $300 \mathrm{~A}$ & Muscle & Sr-90 & $11 / 2 / 90$ & $-2.23 \mathrm{E}-04$ & $2.41 \mathrm{E}-03$ & $2.65 \mathrm{E}-03$ \\
\hline $300 \mathrm{~A}$ & Muscle & ST -90 & $11 / 2 / 90$ & 7.27E-04 & 2.11E-03 & $2.29 \mathrm{E}-03$ \\
\hline $300 \mathrm{~A}$ & Muscle & Sr-90 & $11 / 2 / 90$ & $1.05 \mathrm{E}-03$ & 2.23E-03 & 2.43E-03 \\
\hline $300 \mathrm{~A}$ & Muscle & Sr-90 & $11 / 2 / 90$ & $1.32 \mathrm{E}-03$ & $2.12 \mathrm{E}-03$ & $2.35 \mathrm{E}-03$ \\
\hline $300 \mathrm{~A}$ & Muscle & Sr-90 & $12 / 19 / 91$ & $-3.24 \mathrm{E}-04$ & $1.88 \mathrm{E}-03$ & $2.04 \mathrm{E}-03$ \\
\hline $300 \mathrm{~A}$ & Muscle & Sr-90 & $12 / 19 / 91$ & $-1.13 \mathrm{E}-04$ & $4.64 \mathrm{E}-03$ & $5.15 \mathrm{E}-03$ \\
\hline $300 \mathrm{~A}$ & Muscle & $\mathrm{Sr}-90$ & $12 / 17 / 92$ & $-8.02 E-04$ & $4.55 \mathrm{E}-03$ & $4.74 \mathrm{E}-03$ \\
\hline $300 \mathrm{~A}$ & Muscle & Sr-90 & $12 / 17 / 92$ & $3.60 \mathrm{E}-05$ & $2.05 \mathrm{E}-03$ & $2.26 \mathrm{E}-03$ \\
\hline $300 \mathrm{~A}$ & Muscle & Sr-90 & $12 / 17 / 92$ & $7.98 \mathrm{E}-04$ & $4.80 \mathrm{E}-03$ & $4.92 \mathrm{E}-03$ \\
\hline $300 \mathrm{~A}$ & Muscle & Sr-90 & $12 / 17 / 92$ & $2.26 \mathrm{E}-03$ & $5.64 \mathrm{E}-03$ & $5.74 \mathrm{E}-03$ \\
\hline $300 \mathrm{~A}$ & Muscle & $\mathrm{Sr}-90$ & $12 / 17 / 92$ & $2.75 \mathrm{E}-03$ & $1.16 \mathrm{E}-02$ & $1.18 \mathrm{E}-02$ \\
\hline $300 \mathrm{~A}$ & Muscle & Tc-99 & $12 / 19 / 91$ & $-1.95 \mathrm{E}-01$ & $3.54 \mathrm{E}-01$ & $1.07 E+00$ \\
\hline $300 \mathrm{~A}$ & Muscle & Tc-99 & $12 / 19 / 91$ & $-1.93 E-01$ & $2.88 \mathrm{E}-01$ & 8.67E-01 \\
\hline $300 \mathrm{~A}$ & Muscle & Tc-99 & $12 / 17 / 92$ & $-3.09 E-01$ & $1.29 \mathrm{E}-01$ & $4.08 \mathrm{E}-01$ \\
\hline $300 \mathrm{~A}$ & Muscle & Tc-99 & $12 / 17 / 92$ & $-1.46 \mathrm{E}-01$ & $1.37 \mathrm{E}-01$ & $4.29 \mathrm{E}-01$ \\
\hline $300 \mathrm{~A}$ & Muscle & Tc-99 & $12 / 17 / 92$ & $-1.39 \mathrm{E}-01$ & $1.38 \mathrm{E}-01$ & $4.32 \mathrm{E}-01$ \\
\hline $300 \mathrm{~A}$ & Muscle & Tc-99 & $12 / 17 / 92$ & $-8.20 \mathrm{E}-02$ & 1.39E-01 & $4.34 \mathrm{E}-01$ \\
\hline $300 \mathrm{~A}$ & Muscle & Tc-99 & $12 / 17 / 92$ & $-6.10 \mathrm{E}-02$ & $1.26 \mathrm{E}-01$ & $3.94 \mathrm{E}-01$ \\
\hline $300 \mathrm{~A}$ & Muscle & Tc-99 & $12 / 17 / 92$ & $1.21 \mathrm{E}-02$ & $1.16 \mathrm{E}-01$ & $3.64 \mathrm{E}-01$ \\
\hline $300 \mathrm{~A}$ & Muscle & Tc-99 & $12 / 17 / 92$ & $1.85 E+00$ & $1.85 \mathrm{E}-01$ & $6.01 \mathrm{E}-01$ \\
\hline $300 \mathrm{~A}$ & Muscle & $\mathrm{U}-234$ & $12 / 19 / 91$ & $7.15 \mathrm{E}-04$ & $1.10 \mathrm{E}-03$ & $1.15 \mathrm{E}-03$ \\
\hline $300 \mathrm{~A}$ & Muscle & $U-234$ & $12 / 19 / 91$ & $7.88 \mathrm{E}-04$ & $9.99 \mathrm{E}-04$ & $1.04 \mathrm{E}-03$ \\
\hline $300 \mathrm{~A}$ & Muscle & U-234 & $12 / 17 / 92$ & $-6.14 E-04$ & $5.15 E-04$ & $5.79 \mathrm{E}-04$ \\
\hline $300 \mathrm{~A}$ & Muscle & U-234 & $12 / 17 / 92$ & $-4.45 E-04$ & $9.43 E-04$ & $9.74 \mathrm{E}-04$ \\
\hline $300 \mathrm{~A}$ & Muscle & U-234 & $12 / 17 / 92$ & $-3.20 \mathrm{E}-04$ & $9.14 \mathrm{E}-04$ & $9.78 \mathrm{E}-04$ \\
\hline $300 \mathrm{~A}$ & Muscle & $\mathrm{U}-234$ & $12 / 17 / 92$ & $-2.48 E-04$ & $1.00 \mathrm{E}-03$ & $1.04 \mathrm{E}-03$ \\
\hline $300 \mathrm{~A}$ & Muscle & $\mathrm{U}-234$ & $12 / 17 / 92$ & $-1.25 \mathrm{E}-04$ & $9.53 \mathrm{E}-04$ & $1.00 \mathrm{E}-03$ \\
\hline $300 \mathrm{~A}$ & Muscle & $\mathrm{U}-234$ & $12 / 17 / 92$ & $2.74 \mathrm{E}-05$ & $9.74 \mathrm{E}-04$ & $1.02 \mathrm{E}-03$ \\
\hline $300 \mathrm{~A}$ & Muscle & U-234 & $12 / 17 / 92$ & 3.22E-04 & 8.81E-04 & $9.16 \mathrm{E}-04$ \\
\hline
\end{tabular}

- indicates the analytical error exceeds the result (counting error is used when the analytical error is not reported) 
Table A.3. Radionuclide Concentrations in Whitefish, 1982-1992 (continued)

\begin{tabular}{|c|c|c|c|c|c|c|c|}
\hline Location & Tissue & Radionuclide & $\begin{array}{c}\text { Date } \\
(\mathrm{M} / \mathrm{D} / \mathrm{Y})\end{array}$ & $\begin{array}{c}\text { Concentration } \\
\text { (pCi/g wet) }\end{array}$ & $\begin{array}{l}\text { Counting } \\
\text { Error } \\
\text { (pCi/g wet) }\end{array}$ & $\begin{array}{l}\text { Propagated } \\
\text { Analytical } \\
\text { Error } \\
\text { (pCi/g wet) }\end{array}$ & \\
\hline $300 \mathrm{~A}$ & Muscle & U-234 & $12 / 17 / 92$ & $5.4 .8 \mathrm{E}-04$ & $1.20 \mathrm{E}-03$ & $1.24 \mathrm{E}-03$ & $*$ \\
\hline $300 \mathrm{~A}$ & Muscle & U-234 & $12 / 17 / 92$ & $6.38 \mathrm{E}-04$ & $1.20 \mathrm{E}-03$ & $1.24 \mathrm{E}-03$ & $*$ \\
\hline $300 \mathrm{~A}$ & Muscle & U-234 & $12 / 17 / 92$ & $1.06 \mathrm{E}-03$ & 1.19E-03 & $1.23 \mathrm{E}-03$ & $*$ \\
\hline $300 \mathrm{~A}$ & Muscle & U-235 & $12 / 19 / 91$ & $-8.91 E-05$ & 3.93E-04 & 4.01E-04 & * \\
\hline $300 \mathrm{~A}$ & Muscle & $\mathrm{U}-235$ & $12 / 19 / 91$ & $1.77 \mathrm{E}-04$ & 4.00E-04 & 4.07E-04 & * \\
\hline $300 \mathrm{~A}$ & Muscle & U-235 & $12 / 17 / 92$ & $-2.38 \mathrm{E}-0.4$ & $1.85 \mathrm{E}-04$ & $1.99 \mathrm{E}-04$ & * \\
\hline $300 \mathrm{~A}$ & Muscle & U-235 & $12 / 17 / 92$ & $-2.33 E-04$ & $4.68 \mathrm{E}-04$ & 4.75E-04 & * \\
\hline $300 \mathrm{~A}$ & Muscle & $\mathrm{U}-235$. & $12 / 17 / 92$ & $-2.04 \mathrm{E}-04$ & 7.87E-04 & 7.92E-04 & * \\
\hline $300 \mathrm{~A}$ & Muscle & $\mathrm{U}-235^{\circ}$ & $12 / 17 / 92$ & $-9.54 E-05$ & $0.00 \mathrm{E}+00$ & $5.94 \mathrm{E}-04$ & * \\
\hline $300 \mathrm{~A}$ & Muscle & U-235 & $12 / 17 / 92$ & $-8.76 \mathrm{E}-05$ & 4.42E-04 & $4.50 \mathrm{E}-04$ & * \\
\hline $300 \mathrm{~A}$ & Muscle & U-235 & $12 / 17 / 92$ & $-7.57 \mathrm{E}-05$ & $4.45 \mathrm{E}-04$ & $4.52 \mathrm{E}-04$ & * \\
\hline $300 \mathrm{~A}$ & Muscle & U-235 & $12 / 17 / 92$ & $1.49 \mathrm{E}-04$ & $7.21 \mathrm{E}-04$ & $7.26 \mathrm{E}-04$ & * \\
\hline $300 \mathrm{~A}$ & Muscle & $\mathrm{U}-235$ & $12 / 17 / 92$ & $2.47 \mathrm{E}-04$ & $5.00 \mathrm{E}-04$ & $5.06 \mathrm{E}-04$ & * \\
\hline $300 \mathrm{~A}$ & Muscle & $\mathrm{U}-235$ & $12 / 17 / 92$ & 3.21E-04 & $1.14 \mathrm{E}-03$ & $1.14 \mathrm{E}-03$ & * \\
\hline $300 \mathrm{~A}$ & Muscle & U-235 & $12 / 17 / 92$ & 4.64E-04 & 8.71E-04 & $8.76 \mathrm{E}-04$ & $*$ \\
\hline $300 \mathrm{~A}$ & Muscle & $\mathrm{U}-238$ & $12 / 19 / 91$ & 2.00E-04 & 5.65E-04 & $5.88 \mathrm{E}-04$ & * \\
\hline $300 \mathrm{~A}$ & Muscle & U-238 & $12 / 19 / 91$ & $3.62 \mathrm{E}-04$ & $9.64 \mathrm{E}-04$ & $9.83 E-04$ & * \\
\hline $300 \mathrm{~A}$ & Muscle & $\mathrm{U}-238$ & $12 / 17 / 92$ & $-3.29 E-04$ & 4.06E-04 & 4.34E-04 & * \\
\hline $300 \mathrm{~A}$ & Muscle & U-238 & $12 / 17 / 92$ & $-1.72 \mathrm{E}-04$ & 4.98E-04 & $5.22 E-04$ & * \\
\hline $300 \mathrm{~A}$ & Muscle & $\mathrm{U}-238$ & $12 / 17 / 92$ & $6.52 \mathrm{E}-05$ & $7.50 \mathrm{E}-04$ & $7.68 \mathrm{E}-04$ & * \\
\hline $300 \mathrm{~A}$ & Muscle & $\mathrm{U}-238$ & $12 / 17 / 92$ & $1.10 \mathrm{E}-04$ & $9.46 \mathrm{E}-04$ & 9.61E-04 & * \\
\hline $300 \mathrm{~A}$ & Muscle & $\mathrm{U}-238$ & $12 / 17 / 92$ & $2.34 \mathrm{E}-04$ & $9.64 \mathrm{E}-04$ & $9.82 E-04$ & * \\
\hline $300 \mathrm{~A}$ & Muscle & U-238 & $12 / 17 / 92$ & 2.83E-04 & 7.71E-04 & 7.91E-04 & $*$ \\
\hline $300 \mathrm{~A}$ & Muscle & $\mathrm{U}-238$ & $12 / 17 / 92$ & $3.20 \mathrm{E}-04$ & $1.48 \mathrm{E}-03$ & $1.49 \mathrm{E}-03$ & * \\
\hline $300 \mathrm{~A}$ & Muscle & U-238 & $12 / 17 / 92$ & $7.21 \mathrm{E}-04$ & $9.43 \mathrm{E}-04$ & $9.66 \mathrm{E}-04$ & * \\
\hline $300 \mathrm{~A}$ & Muscle & $\mathrm{U}-238$ & $12 / 17 / 92$ & $8.14 \mathrm{E}-04$ & $1.08 \mathrm{E}-03$ & $1.09 \mathrm{E}-03$ & $*$ \\
\hline $300 \mathrm{~A}$ & Muscle & $\mathrm{U}-238$ & $12 / 17 / 92$ & $1.14 \mathrm{E}-03$ & $1.45 \mathrm{E}-03$ & 1.47E-03 & $*$ \\
\hline Han Townsite & Carcass & Co-60 & $3 / 1 / 83$ & $1.34 \mathrm{E}-01$ & $1.62 \mathrm{E}-02$ & Not reported & \\
\hline Han Townsite & Carcass & $\mathrm{Co}-60$ & $3 / 1 / 83$ & $2.84 \mathrm{E}-01$ & $3.86 \mathrm{E}-02$ & Not reported & \\
\hline Han Townsite & Carcass & Co-60 & $3 / 1 / 83$ & $6.26 \mathrm{E}-01$ & $7.27 \mathrm{E}-02$ & Not reported & \\
\hline Han Townsite & Carcass & Co-60 & $4 / 5 / 83$ & $2.58 \mathrm{E}-01$ & 3.62E-02 & Not reported & \\
\hline Han Townsite & Carcass & Co-60 & $4 / 6 / 83$ & $1.05 \mathrm{E}-01$ & $1.79 \mathrm{E}-02$ & Not reported & \\
\hline Han Townsite & Carcass & Co-60 & $4 / 6 / 83$ & 1.22E-01 & $2.46 \mathrm{E}-02$ & Not reported & \\
\hline Han Townsite & Carcass & $\mathrm{Co}-60$ & $5 / 4 / 83$ & $3.62 \mathrm{E}-03$ & $1.98 \mathrm{E}-02$ & Not reported & $*$ \\
\hline Han Townsite & Carcass & Cs-137 & $3 / 1 / 83$ & $1.15 \mathrm{E}-02$ & $6.23 \mathrm{E}-03$ & Not reported & \\
\hline Han Townsite & Carcass & Cs-137 & $3 / 1 / 83$ & $1.71 \mathrm{E}-02$ & $5.16 \mathrm{E}-02$ & Not reported & $*$ \\
\hline Han Townsite & Carcass & Cs- 137 & $3 / 1 / 83$ & $4.52 E-02$ & $3.32 \mathrm{E}-02$ & Not reported & \\
\hline Han Townsite & Carcass & Cs- 137 & $4 / 5 / 83$ & 1.20E-01 & 2.37E-02 & Not reported & \\
\hline Han Townsite & Carcass & Cs-137 & $4 / 6 / 83$ & $2.45 \mathrm{E}-02$ & $8.24 \mathrm{E}-03$ & Not reported & \\
\hline Han Townsite & Carcass & Cs-137 & $4 / 6 / 83$ & 3.32E-02 & $1.78 \mathrm{E}-02$ & Not reported & \\
\hline Han Townsite & Carcass & Cs-137 & $5 / 4 / 83$ & $4.51 \mathrm{E}-03$ & $1.72 \mathrm{E}-02$ & Not reported & $*$ \\
\hline Han Townsite & Carcass & Sr-90 & $3 / 1 / 83$ & $1.22 \mathrm{E}-02$ & $6.15 \mathrm{E}-03$ & Not reported & \\
\hline Han Townsite & Carcass & $\mathrm{Sr}-90$ & $3 / 1 / 83$ & $1.69 E-02$ & $2.44 E-03$ & Not reported & \\
\hline
\end{tabular}


Table A.3. Radionuclide Concentrations in Whitefish, 1982-1992 (continued)

\begin{tabular}{|c|c|c|c|c|c|c|}
\hline Location & Tissue & $\underline{\text { Radionuclide }}$ & $\begin{array}{c}\text { Date } \\
(\mathrm{M} / \mathrm{D} / \mathrm{Y})\end{array}$ & $\begin{array}{c}\text { Concentration } \\
\text { (pCi/g wet) }\end{array}$ & $\begin{array}{l}\text { Counting } \\
\text { Error } \\
\text { (pCi/g wet) }\end{array}$ & $\begin{array}{c}\text { Propagated } \\
\text { Analytical } \\
\text { Error } \\
\text { (pCi/g wet) }\end{array}$ \\
\hline Han Townsite & Carcass & Sr-90 & $3 / 1 / 83$ & $2.58 \mathrm{E}-02$ & $2.42 E-03$ & Not reported \\
\hline Han Townsite & Carcass & Sr-90 & $4 / 5 / 83$ & $3.38 \mathrm{E}-02$ & $3.67 \mathrm{E}-03$ & Not reported \\
\hline Han Townsite & Carcass & Sr-90 & $4 / 6 / 83$ & $1.64 \mathrm{E}-02$ & $1.86 \mathrm{E}-03$ & Not reported \\
\hline Han Townsite & Carcass & Sr-90 & $4 / 6 / 83$ & $2.50 \mathrm{E}-02$ & $3.23 \mathrm{E}-03$ & Not reported \\
\hline Han Townsite & Carcass & Sr-90 & $5 / 4 / 83$ & 1.99E-02 & $2.54 \mathrm{E}-03$ & Not reported \\
\hline Han Townsite & Muscle & $\mathrm{Co}-60$ & $3 / 1 / 83$ & $2.14 \mathrm{E}-02$ & $1.53 \mathrm{E}-02$ & Not reported \\
\hline Han Townsite & Muscle & $\mathrm{Co}-60$ & $3 / 1 / 83$ & 4.04E-02 & $3.79 \mathrm{E}-02$ & Not reported \\
\hline Han Townsite & Muscle & $\mathrm{Co}-60$ & $3 / 1 / 83$ & 7.90E-02 & 3.75E-02 & Not reported \\
\hline Han Townsite & Muscle & Co-60 & $4 / 5 / 83$ & 2.70E-02 & $1.56 \mathrm{E}-02$ & Not reported \\
\hline Han Townsite & Muscle & $\mathrm{Co}-60$ & $4 / 6 / 83$ & $6.13 E-03$ & $1.52 \mathrm{E}-02$ & Not reported \\
\hline Han Townsite & Muscle & Co-60 & $4 / 6 / 83$ & $4.04 E-02$ & $2.11 \mathrm{E}-02$ & Not reported \\
\hline Han Townsite & Muscle & $\mathrm{Co}-60$ & $5 / 4 / 83$ & $-1.96 E-02$ & $6.17 \mathrm{E}-02$ & Not reported \\
\hline Han Townsite & Muscle & Cs-137 & $3 / 1 / 83$ & $-8.51 E-03$ & $3.13 \mathrm{E}-02$ & Not reported \\
\hline Han Townsite & Muscle & Cs-137 & $3 / 1 / 83$ & $2.54 \mathrm{E}-02$ & $9.99 \mathrm{E}-03$ & Not reported \\
\hline Han Townsite & Muscle & Cs-137 & $3 / 1 / 83$ & $4.06 \mathrm{E}-02$ & $3.45 \mathrm{E}-02$ & Not reported \\
\hline Han Townsite & Muscle & Cs-137 & $4 / 5 / 83$ & $2.03 \mathrm{E}-02$ & $7.81 \mathrm{E}-03$ & Not reported \\
\hline Han Townsite & Muscle & Cs-137 & $4 / 6 / 83$ & $1.09 \mathrm{E}-02$ & $6.58 \mathrm{E}-03$ & Not reported \\
\hline Han Townsite & Muscle & Cs-137 & $4 / 6 / 83$ & $3.46 \mathrm{E}-02$ & 1.33E-02 & Not reported \\
\hline Han Townsite & Muscle & Cs-137 & $5 / 4 / 83$ & $4.39 \mathrm{E}-02$ & $5.71 \mathrm{E}-02$ & Not reported \\
\hline Han Townsite & Muscle & Sr-90 & $3 / 1 / 83$ & 4.71E-03 & 2.51E-03 & Not reported \\
\hline Han Townsite & Muscle & Sr-90 & $3 / 1 / 83$ & $5.54 \mathrm{E}-03$ & $3.14 \mathrm{E}-03$ & Not reported \\
\hline Han Townsite & Muscle & Sr-90 & $4 / 5 / 83$ & $3.42 E-03$ & 3.33E-03 & Not reported \\
\hline Han Townsite & Muscle & Sr-90 & $4 / 6 / 83$ & $-1.43 \mathrm{E}-03$ & $6.79 \mathrm{E}-03$ & Not reported \\
\hline Han Townsite & Muscle & Sr -90 & $4 / 6 / 83$ & $-6.76 E-04$ & 4.24E-03 & Not reported \\
\hline Han Townsite & Muscle & Sr-90 & $5 / 4 / 83$ & $1.83 \mathrm{E}-03$ & $3.69 \mathrm{E}-03$ & Not reported \\
\hline Kettle River & Carcass & Sr-90 & 2/19/91 & $1.68 \mathrm{E}-02$ & . 1.32E-02 & $1.40 \mathrm{E}-02$ \\
\hline Kettle River & Carcass & Sr-90 & $2 / 19 / 91$ & $2.58 \mathrm{E}-02$ & $2.02 \mathrm{E}-02$ & $2.11 \mathrm{E}-02$ \\
\hline Kettle River & Carcass & Sr-90 & $2 / 19 / 91$ & $3.20 \mathrm{E}-02$ & 8.85E-03 & $1.15 \mathrm{E}-02$ \\
\hline Kettle River & Carcass & Sr-90 & $2 / 19 / 91$ & $3.51 \mathrm{E}-02$ & $1.22 \mathrm{E}-02$ & $1.43 \mathrm{E}-02$ \\
\hline Kettle River & Carcass & Sr-90 & $2 / 19 / 91$ & 3.63E-02 & $1.12 \mathrm{E}-02$ & $1.40 \mathrm{E}-02$ \\
\hline Kettle River & Carcass & Sr-90 & $2 / 19 / 91$ & $3.65 \mathrm{E}-02$ & $1.11 \mathrm{E}-02$ & $1.34 E-02$ \\
\hline Kettle River & Carcass & Sr-90 & 2/19/91 & $4.06 \mathrm{E}-02$ & 1.13E-02 & $1.40 \mathrm{E}-02$ \\
\hline Kettle River & Carcass & $\mathrm{Sr}-90$ & $2 / 19 / 91$ & $4.10 \mathrm{E}-02$ & $1.33 \mathrm{E}-02$ & $1.55 \mathrm{E}-02$ \\
\hline Kettle River & Carcass & Sr-90 & $2 / 19 / 91$ & $4.76 \mathrm{E}-02$ & $1.35 \mathrm{E}-02$ & $1.68 \mathrm{E}-02$ \\
\hline Kettle River & Muscle & $\mathrm{Co}-60$ & $2 / 19 / 91$ & $-4.88 \mathrm{E}-02$ & $5.56 \mathrm{E}-02$ & $5.59 \mathrm{E}-02$ \\
\hline Kettle River & Muscle & Co-60 & $2 / 19 / 91$ & $-4.68 \mathrm{E}-02$ & $5.31 \mathrm{E}-02$ & $5.33 \mathrm{E}-02$ \\
\hline Kettle River & Muscle & Co-60 & $2 / 19 / 91$ & $-3.69 \mathrm{E}-02$ & $4.21 \mathrm{E}-02$ & 4.23E-02 \\
\hline Kettle River & Muscle & $\mathrm{Co}-60$ & $2 / 19 / 91$ & $-3.20 \mathrm{E}-02$ & 4.33E-02 & $4.34 \mathrm{E}-02$ \\
\hline Kettle River & Muscle & Co-60 & $2 / 19 / 91$ & $-2.73 E-02$ & $3.84 \mathrm{E}-02$ & 3.85E-02 \\
\hline Kettle River & Muscle & $\mathrm{Co}-60$ & $2 / 19 / 91$ & $-1.76 \mathrm{E}-02$ & 2.95E-02 & 2.95E-02 \\
\hline Kettle River & Muscle & $\mathrm{Co}-60$ & $2 / 19 / 91$ & $-1.44 \mathrm{E}-02$ & $3.40 \mathrm{E}-02$ & $3.40 \mathrm{E}-02$ \\
\hline Kettle River & Muscle & $\mathrm{Co}-60$ & $2 / 19 / 91$ & $1.43 \mathrm{E}-02$ & $2.97 E-02$ & $2.97 \mathrm{E}-02$ \\
\hline Kettle River & Muscle & Co-60 & $2 / 19 / 91$ & $4.76 E-02$ & $3.52 E-02$ & $3.55 \mathrm{E}-02$ \\
\hline
\end{tabular}

* indicates the analytical error exceeds the result (counting error is used when the analytical error is not reported) 
Table A.3. Radionuclide Concentrations in Whitefish, 1982-1992 (continued)

\begin{tabular}{|c|c|c|c|c|c|c|}
\hline Location & Tissue & Radionuclide & $\begin{array}{c}\text { Date } \\
(\mathrm{M} / \mathrm{D} / \mathrm{Y})\end{array}$ & $\begin{array}{l}\text { Concentration } \\
\text { (pCi/g wet) }\end{array}$ & $\begin{array}{l}\text { Counting } \\
\text { Error } \\
\text { (pCi/g wet) }\end{array}$ & $\begin{array}{c}\text { Propagated } \\
\text { Analytical } \\
\text { Error } \\
\text { (pCi/g wet) }\end{array}$ \\
\hline Kettle River & $\overline{\text { Muscie }}$ & Cs-137 & $2 / 19 / 91$ & $-3.16 \mathrm{E}-02$ & $3.99 \mathrm{E}-02$ & $4.00 \mathrm{E}-02$ \\
\hline Kettle River & Muscle & Cs-137 & $2 / 19 / 91$ & $-1.30 \mathrm{E}-02$ & $3.67 \mathrm{E}-02$ & $3.68 \mathrm{E}-02$ \\
\hline Kettle River & Muscle & Cs-137 & $2 / 19 / 91$ & $-1.01 E-02$ & $3.26 \mathrm{E}-02$ & $3.26 \mathrm{E}-02$ \\
\hline Kettle River & Muscle & Cs-137 & $2 / 19 / 91$ & 4.61E-03 & 2.91E-02 & $2.91 \mathrm{E}-02$ \\
\hline Kettle River & Muscle & Cs-137 & $2 / 19 / 91$ & 4.82E-03 & 2.29E-02 & 2.29E-02 \\
\hline Kettle River & Muscle & Cs-137 & $2 / 19 / 91$ & $6.34 \mathrm{E}-03$ & $3.90 \mathrm{E}-02$ & $3.90 \mathrm{E}-02$ \\
\hline Kettle River & Muscle & Cs-137 & $2 / 19 / 91$ & $1.46 \mathrm{E}-02$ & $2.43 \mathrm{E}-02$ & $2.44 \mathrm{E}-02$ \\
\hline Kettle River & Muscle & Cs-137 & $2 / 19 / 91$ & $1.76 \mathrm{E}-02$ & $2.97 \mathrm{E}-02$ & $2.98 \mathrm{E}-02$ \\
\hline Kettle River & Muscle & Cs-137 & $2 / 19 / 91$ & $3.51 \mathrm{E}-02$ & $2.59 \mathrm{E}-02$ & 2.61E-02 \\
\hline Kettle River & Muscle & Sr-90 & $2 / 19 / 91$ & $-1.10 \mathrm{E}-03$ & $2.35 \mathrm{E}-03$ & 2.53E-03 \\
\hline Kettle River & Muscle & Sr-90 & $2 / 19 / 91$ & $-9.73 E-04$ & 2.44E-03 & 2.62E-03 \\
\hline Kettle River & Muscle & Sr-90 & $2 / 19 / 91$ & $3.13 \mathrm{E}-05$ & $2.56 \mathrm{E}-03$ & $2.72 \mathrm{E}-03$ \\
\hline Kettle River & Muscle & Sr-90 & $2 / 19 / 91$ & $3.16 \mathrm{E}-04$ & $2.89 \mathrm{E}-03$ & $3.05 E-03$ \\
\hline Kettle River & Muscle & Sr-90 & $2 / 19 / 91$ & $3.74 \mathrm{E}-04$ & $2.11 \mathrm{E}-03$ & $2.31 \mathrm{E}-03$ \\
\hline Kettle River & Muscle & Sr-90 & $2 / 19 / 91$ & $7.85 \mathrm{E}-04$ & 3.01E-03 & $3.18 \mathrm{E}-03$ \\
\hline Kettle River & Muscle & Sr-90 & $2 / 19 / 91$ & 1.07E-03 & $2.58 \mathrm{E}-03$ & $2.76 \mathrm{E}-03$ \\
\hline Kettle River & Muscle & Sr-90 & $2 / 19 / 91$ & $1.32 \mathrm{E}-03$ & $2.46 \mathrm{E}-03$ & $2.66 \mathrm{E}-03$ \\
\hline Kettle River & Muscle & Tc-99 & $2 / 19 / 91$ & $-7.65 \mathrm{E}-02$ & $1.45 \mathrm{E}-01$ & 4.32E-01 \\
\hline Kettle River & Muscle & Tc-99 & $2 / 19 / 91$ & $-3.69 \mathrm{E}-02$ & $1.40 \mathrm{E}-01$ & $4.24 \mathrm{E}-01$ \\
\hline Kettle River & Muscle & Tc-99 & $2 / 19 / 91$ & $-2.67 \mathrm{E}-02$ & $1.40 \mathrm{E}-01$ & $4.23 \mathrm{E}-01$ \\
\hline Kettle River & Muscle & Tc-99 & $2 / 19 / 91$ & $-2.15 \mathrm{E}-02$ & 1.37E-01 & 4.18E-01 \\
\hline Kettle River & Muscle & Tc-99 & $2 / 19 / 91$ & $-8.36 \mathrm{E}-03$ & $1.44 \mathrm{E}-01$ & $4.35 \mathrm{E}-01$ \\
\hline Kettle River & Muscle & Tc-99 & $2 / 19 / 91$ & $2.82 \mathrm{E}-02$ & $1.39 \mathrm{E}-01$ & 4.22E-01 \\
\hline Kettle River & Muscle & Tc-99 & $2 / 19 / 91$ & $4.52 \mathrm{E}-02$ & $1.41 \mathrm{E}-01$ & $4.29 \mathrm{E}-01$ \\
\hline Kettle River & Muscle & Tc-99 & $2 / 19 / 91$ & 7.49E-02 & $1.43 \mathrm{E}-01$ & 4.33E-01 \\
\hline Kettle River & Muscle & Тc-99 & $2 / 19 / 91$ & $1.11 \mathrm{E}-01$ & $1.51 \mathrm{E}-01$ & $4.53 \mathrm{E}-01$ \\
\hline Kettle River & Muscle & U-234 & $2 / 19 / 91$ & $-3: 39 E-04$ & $9.02 \mathrm{E}-04$ & $9.56 \mathrm{E}-04$ \\
\hline Kettle River & Muscle & U-234 & $2 / 19 / 91$ & $-3.62 E-05$ & $1.00 \mathrm{E}-03$ & $1.06 \mathrm{E}-03$ \\
\hline Kettle River & Muscle & U-234 & $2 / 19 / 91$ & 2.23E-04 & $1.87 \mathrm{E}-03$ & $1.90 \mathrm{E}-03$ \\
\hline Kettle River & Muscle & U-234 & $2 / 19 / 91$ & 3.45E-04 & 1.27E-03 & 1.32E-03 \\
\hline Kettle River & Muscle & U-234 & $2 / 19 / 91$ & 7.17E-04 & $1.19 \mathrm{E}-03$ & $1.24 \mathrm{E}-03$ \\
\hline Kettle River & Muscle & U-234 & $2 / 19 / 91$ & 1.37E-03 & $1.96 \mathrm{E}-03$ & $1.99 \mathrm{E}-03$ \\
\hline Kettle River & Muscle & U-234 & $2 / 19 / 91$ & $1.62 \mathrm{E}-03$ & $1.45 \mathrm{E}-03$ & $1.50 \mathrm{E}-03$ \\
\hline Kettle River & Muscle & U-234 & $2 / 19 / 91$ & 2.31E-03 & $1.85 \mathrm{E}-03$ & $1.90 \mathrm{E}-03$ \\
\hline Kettle River & Muscle & U-234 & $2 / 19 / 91$ & $3.05 \mathrm{E}-03$ & $1.80 \mathrm{E}-03$ & $1.86 \mathrm{E}-03$ \\
\hline Kettle River & Muscle & U-235 & $2 / 19 / 91$ & $-8.28 \mathrm{E}-04$ & $6.26 \mathrm{E}-04$ & $6.35 \mathrm{E}-04$ \\
\hline Kettle River & Muscle & U-235 & $2 / 19 / 91$ & $-5.45 \mathrm{E}-04$ & $5.91 \mathrm{E}-04$ & $5.98 \mathrm{E}-04$ \\
\hline Kettle River & Muscle & U-235 & $2 / 19 / 91$ & $-1.28 \mathrm{E}-04$ & 8.20E-04 & 8.24E-04 \\
\hline Kettle River & Muscle & U-235 & $2 / 19 / 91$ & $-8.31 \mathrm{E}-05$ & 5.29E-04 & 5.35E-04 \\
\hline Kettle River & Muscle & U-235 & $2 / 19 / 91$ & $2.14 \mathrm{E}-05$ & 5.33E-04 & $5: 40 \mathrm{E}-04$ \\
\hline Kettle River & Muscle & U-235 & $2 / 19 / 91$ & $1.05 \mathrm{E}-04$ & $5.94 \mathrm{E}-04$ & $6.00 \mathrm{E}-04$ \\
\hline Kettle River & Muscle & U-235 & $2 / 19 / 91$ & $1.85 \mathrm{E}-04$ & 5.73E-04 & 5.79E-04 \\
\hline Kettle River & Muscle & U-235 & $2 / 19 / 91$ & 2.74E-04 & $5.67 \mathrm{E}-04$ & $5.74 \mathrm{E}-04$ \\
\hline
\end{tabular}

* indicates the analytical error exceeds the result (counting error is used when the analytical error is not reported) 
Table A.3. Radionuclide Concentrations in Whitefish, 1982-1992 (continued)

\begin{tabular}{|c|c|c|c|c|c|c|}
\hline Location & Tissue & Radionuclide & $\begin{array}{c}\text { Date } \\
(\mathrm{M} / \mathrm{D} / \mathrm{Y})\end{array}$ & $\begin{array}{l}\text { Concentration } \\
\text { (pCi/g wet) }\end{array}$ & $\begin{array}{l}\text { Counting } \\
\text { Error } \\
\text { (pCi/g wet) }\end{array}$ & $\begin{array}{l}\text { Propagated } \\
\text { Analytical } \\
\text { Error } \\
\text { (pCi/g wet) }\end{array}$ \\
\hline Kettle River & $\overline{\text { Muscle }}$ & $\mathrm{U}-235$ & $2 / 19 / 91$ & $7.24 \mathrm{E}-04$ & $1.04 \mathrm{E}-03$ & $1.05 \mathrm{E}-03$ \\
\hline Kettle River & Muscle & $\mathrm{U}-238$ & $2 / 19 / 91$ & $-3.58 \mathrm{E}-04$ & $6.33 \mathrm{E}-04$ & $6.59 \mathrm{E}-04$ \\
\hline Kettle River & Muscle & U-238 & $2 / 19 / 91$ & 8.41E-06 & 9.23E-04 & 9.42E-04 \\
\hline Kettle River & Muscle & $\mathrm{U}-238$ & $2 / 19 / 91$ & $1.81 \mathrm{E}-04$ & 8.10E-04 & 8.33E-04 \\
\hline Kettle River & Muscle & $\mathrm{U}-238$ & $2 / 19 / 91$ & 2.01E-04 & $1.13 \mathrm{E}-03$ & $1.14 \mathrm{E}-03$ \\
\hline Kettle River & Muscle & $\mathrm{U}-238$ & $2 / 19 / 91$ & $2.56 \mathrm{E}-04$ & $9.89 \mathrm{E}-04$ & $1.01 \mathrm{E}-03$ \\
\hline Kettle River & Muscle & U-238 & $2 / 19 / 91$ & $7.86 \mathrm{E}-04$ & $1.37 \mathrm{E}-03$ & $1.39 \mathrm{E}-03$ \\
\hline Kettle River & Muscle & U-238 & $2 / 19 / 91$ & $1.65 \mathrm{E}-03$ & $1.45 \mathrm{E}-03$ & $1.47 \mathrm{E}-03$ \\
\hline Kettle River & Muscle & U-238 & $2 / 19 / 91$ & $1.67 \mathrm{E}-03$ & $1.48 \mathrm{E}-03$ & $1.50 \mathrm{E}-03$ \\
\hline Kettle River & Muscle & U-238 & $2 / 19 / 91$ & 3.33E-03 & $1.81 \mathrm{E}-03$ & $1.86 \mathrm{E}-03$ \\
\hline Priest Rapids & Muscle & $\mathrm{Co}-60$ & $12 / 1 / 83$ & $-1.39 \mathrm{E}-02$ & $2.16 \mathrm{E}-02$ & Not reported \\
\hline Priest Rapids & Muscle & Co-60 & $12 / 1 / 83$ & $1.01 \mathrm{E}-02$ & $1.42 \mathrm{E}-02$ & Not reported \\
\hline Priest Rapids & Muscle & Co-60 & $12 / 2 / 83$ & $-2.51 \mathrm{E}-02$ & $1.72 \mathrm{E}-02$ & Not reported \\
\hline Priest Rapids & Muscle & Co-60 & $12 / 2 / 83$ & $-1.75 \mathrm{E}-02$ & $1.66 \mathrm{E}-02$ & Not reported \\
\hline Priest Rapids & Muscle & $\mathrm{Co}-60$ & $12 / 2 / 83$ & $1.69 \mathrm{E}-02$ & 1:32E-02 & Not reported \\
\hline Priest Rapids & Muscle & Co-60 & $11 / 14 / 84$ & $-2.39 E-03$ & $1.59 \mathrm{E}-02$ & $1.59 \mathrm{E}-02$ \\
\hline Priest Rapids & Muscle & Co-60 & $11 / 14 / 84$ & $1.95 \mathrm{E}-02$ & $1.50 \mathrm{E}-02$ & $1.50 \mathrm{E}-02$ \\
\hline Priest Rapids & Muscle & Co-60 & $12 / 4 / 84$ & $1.55 \mathrm{E}-03$ & $1.95 \mathrm{E}-02$ & $1.95 \mathrm{E}-02$ \\
\hline Priest Rapids & Muscle & $\mathrm{Co}-60$ & $12 / 4 / 84$ & $7.26 \mathrm{E}-03$ & $1.18 \mathrm{E}-02$ & $1.18 \mathrm{E}-02$ \\
\hline Priest Rapids & Muscle & $\mathrm{Co}-60$ & $12 / 4 / 84$ & $1.45 \mathrm{E}-02$ & 1.62E-02 & $1.62 \mathrm{E}-02$ \\
\hline Priest Rapids & Muscle & $\mathrm{Co}-60$ & $11 / 13 / 85$ & $3.04 \mathrm{E}-03$ & $3.16 \mathrm{E}-02$ & $3.16 \mathrm{E}-02$ \\
\hline Priest Rapids & Muscle & $\mathrm{Co}-60$ & $11 / 13 / 85$ & 2.04E-02 & 3.85E-02 & 3.85E-02 \\
\hline Priest Rapids & Muscle & Co-60 & $11 / 13 / 85$ & $3.29 \mathrm{E}-02$ & 2.84E-02 & $2.84 \mathrm{E}-02$ \\
\hline Priest Rapids & Muscle & $\mathrm{Co}-60$ & $11 / 14 / 85$ & $5.19 \mathrm{E}-02$ & 2.32E-02 & $2.34 E-02$ \\
\hline Priest Rapids & Muscle & Co-60 & $9 / 25 / 86$ & $1.85 \mathrm{E}-02$ & $2.10 \mathrm{E}-02$ & $2.11 E-02$ \\
\hline Priest Rapids & Muscle & $\mathrm{Co}-60$ & $10 / 16 / 86$ & $-2.74 \mathrm{E}-02$ & $2.91 \mathrm{E}-02$ & 2.92E-02 \\
\hline Priest Rapids & Muscle & Co-60 & $11 / 18 / 86$ & $1.60 \mathrm{E}-02$ & $2.79 \mathrm{E}-02$ & $2.80 \mathrm{E}-02$ \\
\hline Priest Rapids & Muscle & $\mathrm{Co}-60$ & $11 / 18 / 86$ & $2.29 \mathrm{E}-02$ & 3.33E-02 & $3.34 \mathrm{E}-02$ \\
\hline Priest Rapids & Muscle & Co-60 & $12 / 5 / 86$ & $2.51 \mathrm{E}-02$ & $4.36 \mathrm{E}-02$ & 4.37E-02 \\
\hline Priest Rapids & Muscle & Co-60 & $10 / 1 / 87$ & $-4.12 \mathrm{E}-02$ & $2.97 \mathrm{E}-02$ & $3.00 \mathrm{E}-02$ \\
\hline Priest Rapids & Muscle & Co-60 & $10 / 1 / 87$ & $2.21 \mathrm{E}-02$ & $2.21 \mathrm{E}-02$ & $2.22 \mathrm{E}-02$ \\
\hline Priest Rapids & Muscle & $\mathrm{Co}-60$ & $10 / 2 / 87$ & $2.30 \mathrm{E}-02$ & $2.19 \mathrm{E}-02$ & $2.20 \mathrm{E}-02$ \\
\hline Priest Rapids & Muscle & Co-60 & $10 / 30 / 87$ & $6.85 \mathrm{E}-03$ & $2.46 \mathrm{E}-02$ & $2.46 \mathrm{E}-02$ \\
\hline Priest Rapids & Muscle & $\mathrm{Co}-60$ & $10 / 30 / 87$ & $1.87 \mathrm{E}-02$ & $3.87 \mathrm{E}-02$ & $3.88 \mathrm{E}-02$ \\
\hline Priest Rapids & Muscle & Co-60 & $11 / 7 / 88$ & 7.17E-03 & $1.80 \mathrm{E}-02$ & $1.80 \mathrm{E}-02$ \\
\hline Priest Rapids & Muscle & Co-60 & $11 / 7 / 88$ & $1.07 \mathrm{E}-02$ & $2.28 \mathrm{E}-02$ & $2.28 \mathrm{E}-02$ \\
\hline Priest Rapids & Muscle & Co-60 & $11 / 10 / 88$ & $-1.38 \mathrm{E}-04$ & $1.52 \mathrm{E}-02$ & $1.52 \mathrm{E}-02$ \\
\hline Priest Rapids & Muscle & Co-60 & $11 / 10 / 88$ & $3.04 \mathrm{E}-03$ & $2.08 \mathrm{E}-02$ & $2.08 \mathrm{E}-02$ \\
\hline Priest Rapids & Muscle & Co-60 & $11 / 10 / 88$ & $4.48 \mathrm{E}-03$ & $1.96 \mathrm{E}-02$ & $1.96 \mathrm{E}-02$ \\
\hline Priest Rapids & Muscle & Co-60 & $12 / 11 / 89$ & $-1.41 E-02$ & $1.84 \mathrm{E}-02$ & $1.85 \mathrm{E}-02$ \\
\hline Priest Rapids & Muscle & Co-60 & $12 / 11 / 89$ & $2.86 \mathrm{E}-03$ & $1.85 \mathrm{E}-02$ & $1.85 \mathrm{E}-02$ \\
\hline Priest Rapids & Muscle & Co-60 & $12 / 11 / 89$ & 3.39E-03 & $1.61 \mathrm{E}-02$ & $1.61 \mathrm{E}-02$ \\
\hline Priest Rapids & Muscle & Co-60 & $12 / 11 / 89$ & 1.67E-02 & $1.90 \mathrm{E}-02$ & $1.91 \mathrm{E}-02$ \\
\hline
\end{tabular}

* indicates the analytical error exceeds the result (counting error is used when the analytical error is not reported) 
Table A.3. Radionuclide Concentrations in Whitefish, 1982-1992 (continued)

\begin{tabular}{|c|c|c|c|c|c|c|}
\hline Location & Tissue & $\underline{\text { Radionuclide }}$ & $\begin{array}{c}\text { Date } \\
(\mathrm{M} / \mathrm{D} / \mathrm{Y})\end{array}$ & $\begin{array}{l}\text { Concentration } \\
\text { (pCi/g wet) }\end{array}$ & $\begin{array}{l}\text { Counting } \\
\text { Error } \\
\text { (pCi/g wet) }\end{array}$ & $\begin{array}{l}\text { Propagated } \\
\text { Analytical } \\
\text { Error } \\
\text { (pCi/g wet) }\end{array}$ \\
\hline Priest Rapids & $\overline{\text { Muscle }}$ & Co-60 & $12 / 22 / 89$ & 3.27E-02 & $2.23 \mathrm{E}-02$ & $2.26 \mathrm{E}-02$ \\
\hline Priest Rapids & Muscle & Co-60 & $10 / 22 / 90$ & $2.00 \mathrm{E}-03$ & 3.57E-02 & 3.57E-02 \\
\hline Priest Rapids & Muscle & Co-60 & $10 / 26 / 90$ & $-3.12 E-03$ & 4.36E-02 & $4.36 \mathrm{E}-02$ \\
\hline Priest Rapids & Muscle & Co-60 & $10 / 29 / 90$ & $-1.51 E-03$ & $3.55 \mathrm{E}-02$ & $3.55 \mathrm{E}-02$ \\
\hline Priest Rapids & Muscle & Co-60 & $10 / 29 / 90$ & $3.05 \mathrm{E}-02$ & 3.61E-02 & $3.62 \mathrm{E}-02$ \\
\hline Priest Rapids & Muscle & $\mathrm{Co}-60$ & $10 / 31 / 90$ & 4.07E-02 & $3.42 \mathrm{E}-02$ & 3.44E-02 \\
\hline Priest Rapids & Muscle & Cs- 137 & $12 / 1 / 83$ & $1.68 \mathrm{E}-02$ & $9.10 \mathrm{E}-03$ & Not reported \\
\hline Priest Rapids & Muscle & Cs- 137 & $12 / 1 / 83$ & $1.80 \mathrm{E}-02$ & 1.62E-02 & Not reported \\
\hline Priest Rapids & Muscle & Cs-137 & $12 / 2 / 83$ & $-6.84 \mathrm{E}-03$ & $1.33 \mathrm{E}-02$ & Not reported \\
\hline Priest Rapids & Muscle & Cs-137 & $12 / 2 / 83$ & $1.62 \mathrm{E}-02$ & $8.74 \mathrm{E}-03$ & Not reported \\
\hline Priest Rapids & Muscle & Cs-137 & $12 / 2 / 83$ & $2.68 \mathrm{E}-02$ & $1.13 \mathrm{E}-02$ & Not reported \\
\hline Priest Rapids & Muscle & Cs-137 & $11 / 14 / 84$ & $-3.25 E-03$ & $1.56 \mathrm{E}-02$ & $1.56 \mathrm{E}-02$ \\
\hline Priest Rapids & Muscle & Cs-137 & $11 / 14 / 84$ & $8.66 \mathrm{E}-03$ & $1.47 \mathrm{E}-02$ & $1.47 \mathrm{E}-02$ \\
\hline Priest Rapids & Muscle & Cs-137 & $12 / 4 / 84$ & $-1.48 \mathrm{E}-03$ & $1.20 \mathrm{E}-02$ & $1.20 \mathrm{E}-02$ \\
\hline Priest Rapids & Muscle & Cs-137 & $12 / 4 / 84$ & $1.56 \mathrm{E}-02$ & 1.37E-02 & $1.38 \mathrm{E}-02$ \\
\hline Priest Rapids & Muscle & Cs-137 & $12 / 4 / 84$ & $3.38 \mathrm{E}-02$ & $1.59 \mathrm{E}-02$ & $1.61 \mathrm{E}-02$ \\
\hline Priest Rapids & Muscle & Cs-137 & $11 / 13 / 85$ & $-2.22 \mathrm{E}-03$ & $3.73 E-02$ & $3.73 \mathrm{E}-02$ \\
\hline Priest Rapids & Muscle & Cs-137 & $11 / 13 / 85$ & $-9.39 E-04$ & $3.73 E-02$ & 3.73E-02 \\
\hline Priest Rapids & Muscle & Cs-137 & $11 / 13 / 85$ & $2.37 \mathrm{E}-02$ & $3.06 \mathrm{E}-02$ & $3.06 \mathrm{E}-02$ \\
\hline Priest Rapids & Muscle & Cs-137 & $11 / 14 / 85$ & $1.02 \mathrm{E}-02$ & $3.29 E-02$ & $3.29 \mathrm{E}-02$ \\
\hline Priest Rapids & Muscle & Cs-137 & $9 / 25 / 86$ & $3.01 \mathrm{E}-02$ & $2.29 \mathrm{E}-02$ & $2.31 \mathrm{E}-02$ \\
\hline Priest Rapids & Muscle & Cs-137 & $10 / 16 / 86$ & $6.40 \mathrm{E}-04$ & $2.55 \mathrm{E}-02$ & $2.55 \mathrm{E}-02$ \\
\hline Priest Rapids & Muscle & Cs-137 & $11 / 18 / 86$ & $1.29 \mathrm{E}-02$ & 4.59E-02 & $4.59 \mathrm{E}-02$ \\
\hline Priest Rapids & Muscle & Cs-137 & $11 / 18 / 86$ & $4.31 E-02$ & $3.69 \mathrm{E}-02$ & $3.72 \mathrm{E}-02$ \\
\hline Priest Rapids & Muscle & Cs-137 & $12 / 5 / 86$ & $4.56 \mathrm{E}-02$ & $3.36 \mathrm{E}-02$ & $3.39 \mathrm{E}-02$ \\
\hline Priest Rapids & Muscle & Cs-137 & $10 / 1 / 87$ & $-2.21 E-03$ & $2.91 \mathrm{E}-02$ & 2.91E-02 \\
\hline Priest Rapids & Muscle & Cs- 137 & $10 / 1 / 87$ & $3.08 \mathrm{E}-02$ & $1.97 \mathrm{E}-02$ & $1.99 \mathrm{E}-02$ \\
\hline Priest Rapids & Muscle & Cs-137 & $10 / 2 / 87$ & $-3.09 \mathrm{E}-03$ & $3.45 \mathrm{E}-02$ & $3.45 \mathrm{E}-02$ \\
\hline Priest Rapids & Muscle & Cs-137 & $10 / 30 / 87$ & $1.93 \mathrm{E}-02$ & 2.64E-02 & $2.65 \mathrm{E}-02$ \\
\hline Priest Rapids & Muscle & Cs-137 & $10 / 30 / 87$ & $3.29 \mathrm{E}-02$ & $3.47 \mathrm{E}-02$ & $3.48 \mathrm{E}-02$ \\
\hline Priest Rapids & Muscle & Cs -137 & $11 / 7 / 88$ & $4.06 \mathrm{E}-03$ & $1.83 \mathrm{E}-02$ & $1.83 \mathrm{E}-02$ \\
\hline Priest Rapids & Muscle & Cs-137 & $11 / 7 / 88$ & 1.09E-02 & $2.20 \mathrm{E}-02$ & $2.20 \mathrm{E}-02$ \\
\hline Priest Rapids & Muscle & Cs-137 & $11 / 10 / 88$ & $3.09 \mathrm{E}-03$ & $1.36 \mathrm{E}-02$ & $1.36 \mathrm{E}-02$ \\
\hline Priest Rapids & Muscle & Cs- 137 & $11 / 10 / 88$ & $1.00 \mathrm{E}-02$ & $2.23 \mathrm{E}-02$ & 2.23E-02 \\
\hline Priest Rapids & Muscle & Cs-137 & $11 / 10 / 88$ & $1.36 \mathrm{E}-02$ & $2.10 \mathrm{E}-02$ & $2.11 E-02$ \\
\hline Priest Rapids & Muscle & Cs- 137 & $12 / 11 / 89$ & 8.82E-03 & $1.79 \mathrm{E}-02$ & $1.79 \mathrm{E}-02$ \\
\hline Priest Rapids & Muscle & Cs-137 & $12 / 11 / 89$ & $9.38 \mathrm{E}-03$ & $1.36 \mathrm{E}-02$ & $1.36 \mathrm{E}-02$ \\
\hline Priest Rapids & Muscle & Cs-137 & $12 / 11 / 89$ & $1.36 \mathrm{E}-02$ & $1.67 \mathrm{E}-02$ & $1.67 \mathrm{E}-02$ \\
\hline Priest Rapids & Muscle & Cs-137 & $12 / 11 / 89$ & $2.64 \mathrm{E}-02$ & $1.66 \mathrm{E}-02$ & $1.68 \mathrm{E}-02$ \\
\hline Priest Rapids & Muscle & Cs- 137 & $12 / 22 / 89$ & $5.73 E-03$ & $2.60 \mathrm{E}-02$ & $2.60 \mathrm{E}-02$ \\
\hline Priest Rapids & Muscle & Cs-137 & $10 / 22 / 90$ & $4.80 \mathrm{E}-03$ & 3.70E-02 & 3.70E-02 \\
\hline Priest Rapids & Muscle & Cs-137 & $10 / 26 / 90$ & $2.38 \mathrm{E}-02$ & $3.36 \mathrm{E}-02$ & $3.37 \mathrm{E}-02$ \\
\hline Priest Rapids & Muscle & Cs- 137 & $10 / 29 / 90$ & $-1.41 \mathrm{E}-02$ & $3.28 \mathrm{E}-02$ & $3.29 \mathrm{E}-02$ \\
\hline
\end{tabular}

* indicates the analytical error exceeds the result (counting error is used when the analytical error is not reported) 
Table A.3. Radionuclide Concentrations in Whitefish, 1982-1992 (continued)

\begin{tabular}{|c|c|c|c|c|c|c|}
\hline Location & Tissue & Radionuclide & $\begin{array}{c}\text { Date } \\
(\mathrm{M} / \mathrm{D} / \mathrm{Y})\end{array}$ & $\begin{array}{c}\text { Concentration } \\
\text { (pCi/g wet) }\end{array}$ & $\begin{array}{l}\text { Counting } \\
\text { Error } \\
\text { (pCi/g wet) }\end{array}$ & $\begin{array}{l}\text { Propagated } \\
\text { Analytical } \\
\text { Error } \\
\text { (pCi/g wet) }\end{array}$ \\
\hline Priest Rapids & $\overline{\text { Muscle }}$ & $\mathrm{Cs}-137$ & $10 / 29 / 90$ & 3.97E-02 & $3.61 \mathrm{E}-02$ & $3.63 \mathrm{E}-02$ \\
\hline Priest Rapids & Muscle & Cs-137 & $10 / 31 / 90$ & $-6.78 E-03$ & 3.32E-02 & 3.32E-02 \\
\hline Priest Rapids & Muscle & Sr-90 & $12 / 1 / 83$ & $-6.78 E-03$ & $7.58 \mathrm{E}-03$ & Not reported \\
\hline Priest Rapids & Muscle & Sr-90 & $12 / 1 / 83$ & $5.07 \mathrm{E}-03$ & $5.42 \mathrm{E}-03$ & Not reported \\
\hline Priest Rapids & Muscle & Sr-90 & $12 / 2 / 83$ & $-4.33 E-03$ & 2.75E-03 & Not reported \\
\hline Priest Rapids & Muscle & Sr-90 & $12 / 2 / 83$ & $-2.53 E-03$ & $3.62 \mathrm{E}-03$ & Not reported \\
\hline Priest Rapids & Muscle & Sr-90 & $12 / 2 / 83$ & $7.25 \mathrm{E}-03$ & $4.90 \mathrm{E}-03$ & Not reported \\
\hline Priest Rapids & Muscle & Sr-90 & $11 / 14 / 84$ & $3.81 E-03$ & $3.98 \mathrm{E}-03$ & 4.05E-03 \\
\hline Priest Rapids & Muscle & Sr-90 & $11 / 14 / 84$ & $4.94 E-03$ & $2.87 E-03$ & 3.02E-03 \\
\hline Priest Rapids & Muscle & Sr-90 & $12 / 4 / 84$ & $1.13 \mathrm{E}-03$ & $2.94 \mathrm{E}-03$ & $2.95 \mathrm{E}-03$ \\
\hline Priest Rapids & Muscle & Sr-90 & $12 / 4 / 84$ & 8.55E-03 & 7.69E-03 & $7.88 \mathrm{E}-03$ \\
\hline Priest Rapids & Muscle & Sr-90 & $12 / 4 / 84$ & $2.15 \mathrm{E}-02$ & $6.09 \mathrm{E}-03$ & $7.38 \mathrm{E}-03$ \\
\hline Priest Rapids & Muscle & Sr-90 & $11 / 13 / 85$ & $3.11 \mathrm{E}-03$ & $1.81 \mathrm{E}-03$ & $1.91 E-03$ \\
\hline Priest Rapids & Muscle & $\mathrm{Sr}-90$ & $11 / 13 / 85$ & $3.59 \mathrm{E}-03$ & $2.15 \mathrm{E}-03$ & $2.26 \mathrm{E}-03$ \\
\hline Priest Rapids & Muscle & Sr-90 & $11 / 13 / 85$ & $4.39 \mathrm{E}-03$ & $1.87 \mathrm{E}-03$ & $2.05 \mathrm{E}-03$ \\
\hline Priest Rapids & Muscle & Sr-90 & $11 / 14 / 85$ & $3.66 \mathrm{E}-03$ & $1.41 \mathrm{E}-03$ & $1.58 \mathrm{E}-03$ \\
\hline Priest Rapids & Muscle & Sr-90 & $9 / 25 / 86$ & $3.78 \mathrm{E}-03$ & $2.27 \mathrm{E}-03$ & 2.39E-03 \\
\hline Priest Rapids & Muscle & Sr-90 & $10 / 16 / 86$ & $1.62 \mathrm{E}-03$ & $1.47 \mathrm{E}-03$ & $1.50 \mathrm{E}-03$ \\
\hline Priest Rapids & Muscle & Sr-90 & $11 / 18 / 86$ & $2.23 E-03$ & $2.85 E-03$ & $2.92 \mathrm{E}-03$ \\
\hline Priest Rapids & Muscle & Sr-90 & $11 / 18 / 86$ & $3.71 E-03$ & $2.72 \mathrm{E}-03$ & $2.83 \mathrm{E}-03$ \\
\hline Priest Rapids & Musčle & Sr-90 & $12 / 5 / 86$ & $1.10 \mathrm{E}-02$ & 2.14E-03 & $3.54 \mathrm{E}-03$ \\
\hline Priest Rapids & Muscle & Sr-90 & $10 / 1 / 87$ & $-3.02 E-04$ & $2.31 \mathrm{E}-03$ & $2.40 E-03$ \\
\hline Priest Rapids & Muscle & Sr-90 & $10 / 1 / 87$ & $4.96 \mathrm{E}-04$ & $2.59 \mathrm{E}-03$ & 2.65E-03 \\
\hline Priest Rapids & Muscle & Sr-90 & $10 / 2 / 87$ & $-6.23 E-04$ & $1.54 \mathrm{E}-03$ & $1.60 \mathrm{E}-03$ \\
\hline Priest Rapids & Muscle & Sr-90 & $10 / 30 / 87$ & $3.98 \mathrm{E}-04$ & $1.75 \mathrm{E}-03$ & $1.85 \mathrm{E}-03$ \\
\hline Priest Rapids & Muscle & Sr-90 & $10 / 30 / 87$ & $1.49 \mathrm{E}-03$ & $2.09 \mathrm{E}-03$ & $2.27 \mathrm{E}-03$ \\
\hline Priest Rapids & Muscle & Sr-90 & $11 / 7 / 88$ & $2.92 \mathrm{E}-04$ & $1.59 \mathrm{E}-03$ & $1.74 \mathrm{E}-03$ \\
\hline Priest Rapids & Muscle & Sr-90 & $11 / 7 / 88$ & $2.70 \mathrm{E}-03$ & $3.12 \mathrm{E}-03$ & $3.32 \mathrm{E}-03$ \\
\hline Priest Rapids & Muscle & Sr-90 & $11 / 10 / 88$ & $1.41 \mathrm{E}-04$ & $2.46 \mathrm{E}-03$ & $2.56 \mathrm{E}-03$ \\
\hline Priest Rapids & Muscle & Sr-90 & $11 / 10 / 88$ & $1.25 \mathrm{E}-03$ & 3.71E-03 & 3.87E-03. \\
\hline Priest Rapids & Muscle & Sr-90 & $11 / 10 / 88$ & $1.45 \mathrm{E}-03$ & $4.02 \mathrm{E}-03$ & $4.16 \mathrm{E}-03$ \\
\hline Priest Rapids & Muscle & Sr-90 & $12 / 11 / 89$ & 2.95E-03 & 2.32E-03 & 2.77E-03 \\
\hline Priest Rapids & Muscle & Sr-90 & $12 / 11 / 89$ & $3.21 E-03$ & $1.84 \mathrm{E}-03$ & 2.27E-03 \\
\hline Priest Rapids & Muscle & Sr-90 & $12 / 11 / 89$ & $4.20 \mathrm{E}-03$ & $2.70 \mathrm{E}-03$ & $3.21 \mathrm{E}-03$ \\
\hline Priest Rapids & Muscle & Sr-90 & $12 / 11 / 89$ & $1.86 \mathrm{E}-02$ & $2.84 \mathrm{E}-03$ & $4.72 \mathrm{E}-03$ \\
\hline Priest Rapids & Muscle & $\mathrm{Sr}-90$ & $12 / 22 / 89$ & $1.88 \mathrm{E}-03$ & $2.40 \mathrm{E}-03$ & $2.89 E-03$ \\
\hline Priest Rapids & Muscie & $\mathrm{Sr}-90$ & $10 / 22 / 90$ & $5.96 \mathrm{E}-04$ & $2.05 \mathrm{E}-03$ & $2.28 \mathrm{E}-03$ \\
\hline Priest Rapids & Muscle & Sr-90 & $10 / 26 / 90$ & 1.23E-03 & $2.00 \mathrm{E}-03$ & $2.25 \mathrm{E}-03$ \\
\hline Priest Rapids & Muscle & Sr-90 & $10 / 29 / 90$ & $6.59 \mathrm{E}-04$ & $2.38 \mathrm{E}-03$ & $2.57 \mathrm{E}-03$ \\
\hline Priest Rapids & Musclè & Sr -90 & $10 / 29 / 90$ & $5.37 \mathrm{E}-03$ & $2: 85 E-03$ & $3.22 \mathrm{E}-03$ \\
\hline Priest Rapids & Muscle & Sr-90 & $10 / 31 / 90$ & $2.40 \mathrm{E}-03$ & $2.44 E-03$ & $2.69 \mathrm{E}-03$ \\
\hline Priest Rapids & Carcass & Sr-90 & $12 / 1 / 83$ & $1.42 \mathrm{E}-02$ & $2.20 \mathrm{E}-02$ & Not reported \\
\hline Priest Rapids & Carcass & Sr-90 & $12 / 1 / 83$ & $3.17 \mathrm{E}-02$ & $2.10 \mathrm{E}-02$ & Not reported \\
\hline
\end{tabular}

" indicates the analytical error exceeds the result (counting error is used when the analytical error is not reported) 
Table A.3. Radionuclide Concentrations in Whitefish, 1982-1992 (continued)

\begin{tabular}{|c|c|c|c|c|c|c|}
\hline Location & Tissue & $\underline{\text { Radionuclide }}$ & $\begin{array}{c}\text { Date } \\
(\mathrm{M} / \mathrm{D} / \mathrm{Y})\end{array}$ & $\begin{array}{c}\text { Concentration } \\
\text { (pCi/g wet) }\end{array}$ & $\begin{array}{c}\text { Counting } \\
\text { Error } \\
\text { (pCi/g wet) }\end{array}$ & $\begin{array}{l}\text { Propagated } \\
\text { Analytical } \\
\text { Error } \\
\text { (pCi/g wet) }\end{array}$ \\
\hline Priest Rapids & $\overline{\text { Carcass }}$ & Sr-90 & $12 / 2 / 83$ & $2.43 \mathrm{E}-02$ & $4.86 \mathrm{E}-03$ & Not reported \\
\hline Priest Rapids & Carcass & Sr-90 & $12 / 4 / 84$ & 2.14E-02 & $3.10 \mathrm{E}-03$ & 5.19E-03 \\
\hline Priest Rapids & Carcass & Sr-90 & $12 / 4 / 84$ & 2.81E-02 & $5.48 \mathrm{E}-03$ & 7.75E-03 \\
\hline Priest Rapids & Carcass & Sr-90 & $12 / 4 / 84$ & $3.47 \mathrm{E}-02$ & $3.35 \mathrm{E}-03$ & 7.49E-03 \\
\hline Priest Rapids & Carcass & Sr-90 & $11 / 13 / 85$ & $2.46 \mathrm{E}-02$ & $3.68 \mathrm{E}-03$ & $6.05 \mathrm{E}-03$ \\
\hline Priest Rapids & Carcass & Sr-90 & $11 / 13 / 85$ & $2.84 \mathrm{E}-02$ & $4.02 \mathrm{E}-03$ & $6.81 \mathrm{E}-03$ \\
\hline Priest Rapids & Carcass & Sr-90 & $11 / 13 / 85$ & $3.79 \mathrm{E}-02$ & $4.50 \mathrm{E}-03$ & $8.60 \mathrm{E}-03$ \\
\hline Priest Rapids & Carcass & Sr-90 & $11 / 14 / 85$ & $2.44 \mathrm{E}-02$ & $3.36 \mathrm{E}-03$ & $5.79 E-03$ \\
\hline Priest Rapids & Carcass & Sr-90 & $9 / 25 / 86$ & $2.28 \mathrm{E}-02$ & $3.59 \mathrm{E}-03$ & 5.75E-03 \\
\hline Priest Rapids & Carcass & Sr -90 & $10 / 16 / 86$ & $1.76 \mathrm{E}-02$ & 4.42E-03 & $5.42 \mathrm{E}-03$ \\
\hline Priest Rapids & Carcass & Sr-90 & $11 / 18 / 86$ & $1.59 \mathrm{E}-02$ & 7.94E-03 & $8.48 \mathrm{E}-03$ \\
\hline Priest Rapids & Carcass & Sr-90 & $11 / 18 / 86$ & $1.92 \mathrm{E}-02$ & $6.96 \mathrm{E}-03$ & $7.82 \mathrm{E}-03$ \\
\hline Priest Rapids & Carcass & Sr-90 & $12 / 5 / 86$ & $1.85 \mathrm{E}-02$ & $2.54 \mathrm{E}-03$ & $5.38 \mathrm{E}-03$ \\
\hline Priest Rapids & Carcass & Sr- 90 & $10 / 1 / 87$ & $1.67 \mathrm{E}-02$ & 3.57E-03 & $5.77 \mathrm{E}-03$ \\
\hline Priest Rapids & Carcass & Sr-90 & $10 / 1 / 87$ & $1.93 \mathrm{E}-02$ & $3.98 \mathrm{E}-03$. & $6.50 \mathrm{E}-03$ \\
\hline Priest Rapids & Carcass & Sr-90 & $10 / 2 / 87$ & $2.14 \mathrm{E}-02$ & $4.78 \mathrm{E}-03$ & $7.50 \mathrm{E}-03$ \\
\hline Priest Rapids & Carcass & Sr-90 & $10 / 30 / 87$ & $1.68 \mathrm{E}-02$ & 2.77E-03 & $5.36 \mathrm{E}-03$ \\
\hline Priest Rapids & Carcass & Sr-90 & $10 / 30 / 87$ & 1.79E-02 & 4.36E-03 & $6.53 \mathrm{E}-03$ \\
\hline Priest Rapids & Carcass & Sr-90 & $11 / 7 / 88$ & $3.65 \mathrm{E}-02$ & $5.94 \mathrm{E}-03$ & $9.03 \mathrm{E}-03$ \\
\hline Priest Rapids & Carcass & Sr-90 & $11 / 7 / 88$ & $5.42 \mathrm{E}-02$ & $6.70 \mathrm{E}-03$ & $1.20 \mathrm{E}-02$ \\
\hline Priest Rapids & Carcass & Sr-90 & $11 / 10 / 88$ & $1.25 \mathrm{E}-02$ & 4.29E-03 & $5.12 \mathrm{E}-03$ \\
\hline Priest Rapids & Carcass & Sr-90 & $11 / 10 / 88$ & $2.00 \mathrm{E}-02$ & 4.13E-03 & $5.80 \mathrm{E}-03$ \\
\hline Priest Rapids & Carcass & Sr-90 & $11 / 10 / 88$ & 3.37E-02 & 5.07E-03 & $8.39 \mathrm{E}-03$ \\
\hline Priest Rapids & Carcass & Sr-90 & $12 / 11 / 89$ & $1.70 \mathrm{E}-02$ & $3.14 \mathrm{E}-03$ & $4.71 E-03$ \\
\hline Priest Rapids & Carcass & Sr-90 & $12 / 11 / 89$ & $1.76 \mathrm{E}-02$ & $2.52 \mathrm{E}-03$ & 4.44E-03 \\
\hline Priest Rapids & Carcass & Sr-90 & $12 / 11 / 89$ & $2.89 \mathrm{E}-02$ & $3.10 \mathrm{E}-03$ & $6.23 \mathrm{E}-03$ \\
\hline Priest Rapids & Carcass & Sr-90 & $12 / 11 / 89$ & $3.24 \mathrm{E}-02$ & 3.44E-03 & $7.08 \mathrm{E}-03$ \\
\hline Priest Rapids & Carcass & Sr-90 & $12 / 22 / 89$ & $1.66 \mathrm{E}-02$ & 2.89E-03 & 4.53E-03 \\
\hline Priest Rapids & Carcass & Sr-90 & $10 / 22 / 90$ & $1.03 \mathrm{E}-02$ & 3.15E-03 & 3.84E-03 \\
\hline Priest Rapids & Carcass & Sr-90 & $10 / 26 / 90$ & $1.59 \mathrm{E}-02$ & $3.49 \mathrm{E}-03$ & 4.58E-03 \\
\hline Priest Rapids & Carcass & Sr-90 & $10 / 29 / 90$ & 8.30E-03 & $2.43 \mathrm{E}-03$ & $3.01 \mathrm{E}-03$ \\
\hline Priest Rapids & Carcass & Sr-90 & $10 / 29 / 90$ & $1.49 \mathrm{E}-02$ & $3.10 \mathrm{E}-03$ & 4.23E-03 \\
\hline Priest Rapids & Carcass & Sr-90 & $10 / 31 / 90$ & $1.20 \mathrm{E}-02$ & 2.63E-03 & 3.52E-03 \\
\hline Ringold & Carcass & $\mathrm{Co}-60$ & $2 / 17 / 83$ & $7.45 \mathrm{E}-02$ & $1.67 \mathrm{E}-02$ & Not reported \\
\hline Ringold & Carcass & Co-60 & $3 / 11 / 83$ & 4.23E-02 & $1.58 \mathrm{E}-02$ & Not reported \\
\hline Ringold & Carcass & Co-60 & $3 / 11 / 83$ & 4.63E-02 & $1.61 \mathrm{E}-02$ & Not reported \\
\hline Ringold & Carcass & $\mathrm{Co}-60$ & $3 / 11 / 83$ & $6.54 \mathrm{E}-02$ & $2.56 \mathrm{E}-02$ & Not reported \\
\hline Ringold & Carcass & Co-60 & $4 / 8 / 83$ & 4.53E-02 & $1.24 \mathrm{E}-02$ & Not reported \\
\hline Ringold & Carcass & Cs-137 & $2 / 17 / 83$ & 4.20E-02 & $1.46 \mathrm{E}-02$ & Not reported \\
\hline Ringold & Carcass & Cs-137 & $3 / 11 / 83$ & $1.12 \mathrm{E}-02$ & $1.26 \mathrm{E}-02$ & Not reported \\
\hline Ringold & Carcass & Cs-137 & $3 / 11 / 83$ & $1.60 \mathrm{E}-02$ & $1.79 \mathrm{E}-02$ & Not reported \\
\hline Ringold & Carcass & Cs-137 & $3 / 11 / 83$ & 2.91E-02 & $2.17 \mathrm{E}-02$ & Not reported \\
\hline Ringold & Carcass & Cs-137 & $4 / 8 / 83$ & 2.43E-02 & $1.09 \mathrm{E}-02$ & Not reported \\
\hline
\end{tabular}

* indicates the analytical error exceeds the result (counting error is used when the analytical error is not reported) 
Table A.3. Radionuclide Concentrations in Whitefish, 1982-1992 (continued)

$\begin{array}{llccccc}\text { Location } & \text { Tissue } & \text { Radionuclide } & \begin{array}{c}\text { Date } \\ \text { (M/D/Y) }\end{array} & \begin{array}{c}\text { Concentration } \\ \text { (pCi/g wet) }\end{array} & \begin{array}{c}\text { Counting } \\ \text { Error } \\ \text { (pCi/g wet) }\end{array} & \begin{array}{c}\text { Propagated } \\ \text { Analytical } \\ \text { Error } \\ \text { (pCi/g wet) }\end{array} \\ \text { Ringold } & \text { Carcass } & \text { Sr-90 } & 2 / 17 / 83 & 2.29 \mathrm{E}-02 & 3.07 \mathrm{E}-03 & \text { Not reported } \\ \text { Ringold } & \text { Carcass } & \text { Sr-90 } & 3 / 11 / 83 & 1.29 \mathrm{E}-02 & 1.16 \mathrm{E}-03 & \text { Not reported } \\ \text { Ringold } & \text { Carcass } & \text { Sr-90 } & 3 / 11 / 83 & 1.76 \mathrm{E}-02 & 2.37 \mathrm{E}-03 & \text { Not reported } \\ \text { Ringold } & \text { Carcass } & \text { Sr-90 } & 3 / 11 / 83 & 1.86 \mathrm{E}-02 & 1.95 \mathrm{E}-03 & \text { Not reported } \\ \text { Ringold } & \text { Carcass } & \text { Sr-90 } & 4 / 8 / 83 & 1.98 \mathrm{E}-02 & 2.25 \mathrm{E}-03 & \text { Not reported } \\ \text { Ringold } & \text { Muscle } & \text { Co-60 } & 2 / 17 / 83 & 1.67 \mathrm{E}-02 & 2.36 \mathrm{E}-02 & \text { Not reported } * \\ \text { Ringold } & \text { Muscle } & \text { Co-60 } & 3 / 11 / 83 & -1.47 \mathrm{E}-02 & 2.14 \mathrm{E}-02 & \text { Not reported } \\ \text { Ringold } & \text { Muscle } & \text { Co-60 } & 3 / 11 / 83 & 6.25 \mathrm{E}-03 & 3.19 \mathrm{E}-02 & \text { Not reported } * \\ \text { Ringold } & \text { Muscle } & \text { Co-60 } & 3 / 11 / 83 & 6.18 \mathrm{E}-02 & 4.90 \mathrm{E}-02 & \text { Not reported } \\ \text { Ringold } & \text { Muscle } & \text { Co-60 } & 4 / 8 / 83 & 3.34 \mathrm{E}-02 & 1.75 \mathrm{E}-02 & \text { Not reported } \\ \text { Ringold } & \text { Muscle } & \text { Cs-137 } & 2 / 17 / 83 & 3.25 \mathrm{E}-02 & 1.55 \mathrm{E}-02 & \text { Not reported } \\ \text { Ringold } & \text { Muscle } & \text { Cs-137 } & 3 / 11 / 83 & -1.49 \mathrm{E}-02 & 2.01 \mathrm{E}-02 & \text { Not reported } \\ \text { Ringold } & \text { Muscle } & \text { Cs-137 } & 3 / 11 / 83 & 4.45 \mathrm{E}-02 & 1.74 \mathrm{E}-02 & \text { Not reported } \\ \text { Ringold } & \text { Muscle } & \text { Cs-137 } & 3 / 11 / 83 & 2.64 \mathrm{E}-01 & 5.10 \mathrm{E}-02 & \text { Not reported } \\ \text { Ringold } & \text { Muscle } & \text { Cs-137 } & 4 / 8 / 83 & 1.84 \mathrm{E}-02 & 9.05 \mathrm{E}-03 & \text { Not reported } \\ \text { Ringold } & \text { Muscle } & \text { Sr-90 } & 3 / 11 / 83 & -4.50 \mathrm{E}-03 & 4.12 \mathrm{E}-03 & \text { Not reported } * \\ \text { Ringold } & \text { Muscle } & \text { Sr-90 } & 3 / 11 / 83 & 3.20 \mathrm{E}-03 & 2.49 \mathrm{E}-03 & \text { Not reported } \\ \text { Ringold } & \text { Muscle } & \text { Sr-90 } & 3 / 11 / 83 & 4.97 \mathrm{E}-03 & 4.51 \mathrm{E}-03 & \text { Not reported } \\ \text { Ringold } & \text { Muscle } & \text { Sr-90 } & 4 / 8 / 83 & 1.57 \mathrm{E}-03 & 1.21 \mathrm{E}-03 & \text { Not reported }\end{array}$

- indicates the analytical error exceeds the result (counting error is used when the analytical error is not reported) 
Table A.4. Radionuclide Concentrations in Salmon, 1988

\begin{tabular}{|c|c|c|c|c|c|c|}
\hline Location & Tissue & Radionuclide & $\begin{array}{c}\text { Date } \\
(\mathrm{M} / \mathrm{D} / \mathrm{Y})\end{array}$ & $\begin{array}{l}\text { Concentration } \\
\text { (pCi/g wet) }\end{array}$ & $\begin{array}{l}\text { Counting } \\
\text { Error } \\
\text { (pCi/g wet) }\end{array}$ & $\begin{array}{c}\text { Propagated } \\
\text { Analytical } \\
\text { Error } \\
\text { (pCi/g wet) }\end{array}$ \\
\hline $100 \mathrm{~F}$ & Muscle & Co-60 & $11 / 11 / 88$ & $-1.26 \mathrm{E}-02$ & $1.89 \mathrm{E}-02$ & $1.89 \mathrm{E}-02$ \\
\hline $100 \mathrm{~F}$ & Muscle & Co- 60 & $11 / 11 / 88$ & $-3.64 \mathrm{E}-03$ & $1.61 \mathrm{E}-02$ & $1.61 \mathrm{E}-02$ \\
\hline $100 \mathrm{~F}$ & Muscle & $\mathrm{Co}-60$ & $11 / 11 / 88$ & $4.95 \mathrm{E}-03$ & $1.70 \mathrm{E}-02$ & $1.70 \mathrm{E}-02$ \\
\hline $100 \mathrm{~F}$ & Muscle & Co-60 & $11 / 11 / 88$ & $9.36 \mathrm{E}-03$ & 2.09E-02 & $2.09 \mathrm{E}-02$ \\
\hline $100 \mathrm{~F}$ & Muscle & Co-60 & $11 / 11 / 88$ & $1.03 \mathrm{E}-02$ & $2.50 \mathrm{E}-02$ & $2.50 \mathrm{E}-02$ \\
\hline $100 \mathrm{~F}$ & Muscle & Cs-137 & $11 / 11 / 88$ & $-2.92 \mathrm{E}-03$ & 2.11E-02 & $2.11 \mathrm{E}-02$ \\
\hline $100 \mathrm{~F}$ & Muscle & Cs-137 & $11 / 11 / 88$ & $5.58 \mathrm{E}-03$ & $2.21 \mathrm{E}-02$ & 2.21E-02 \\
\hline $100 \mathrm{~F}$ & Muscle & Cs- 137 & $11 / 11 / 88$ & $2.30 \mathrm{E}-02$ & $1.89 \mathrm{E}-02$ & $1.91 \mathrm{E}-02$ \\
\hline $100 \mathrm{~F}$ & Muscle & Cs-137 & $11 / 11 / 88$ & $2.62 \mathrm{E}-02$ & $1.87 \mathrm{E}-02$ & $1.89 \mathrm{E}-02$ \\
\hline $100 \mathrm{~F}$ & Muscle & Cs-137 & $11 / 11 / 88$ & $3.13 \mathrm{E}-02$ & $1.67 \mathrm{E}-02$ & $1.70 \mathrm{E}-02$ \\
\hline $100 \mathrm{~F}$ & Muscle & Sr-90 & $11 / 11 / 88$ & $-2.40 \mathrm{E}-03$ & $1.62 \mathrm{E}-03$ & 1.79E-03 \\
\hline $100 \mathrm{~F}$ & Muscle & Sr-90 & $11 / 11 / 88$ & $-1.24 \mathrm{E}-03$ & $1.80 \mathrm{E}-03$ & $1.94 \mathrm{E}-03$ \\
\hline $100 \mathrm{~F}$ & Muscle & Sr-90 & $11 / 11 / 88$ & $6.75 \mathrm{E}-05$ & $2.07 \mathrm{E}-03$ & $2.20 \mathrm{E}-03$ \\
\hline $100 \mathrm{~F}$ & Muscle & Sr-90 & $11 / 11 / 88$ & $1.15 \mathrm{E}-03$ & 2.07E-03 & $2.24 \mathrm{E}-03$ \\
\hline $100 \mathrm{~F}$ & Muscle & Sr-90 & $11 / 11 / 88$ & $1.51 \mathrm{E}-03$ & $1.88 \mathrm{E}-03$ & $2.03 \mathrm{E}-03$ \\
\hline Priest Rapids & Muscle & Co-60 & $11 / 11 / 88$ & $-1.69 \mathrm{E}-02$ & $1.98 \mathrm{E}-02$ & $1.98 \mathrm{E}-02$ \\
\hline Priest Rapids & Muscle & Co-60 & $11 / 11 / 88$ & $-1.15 E-02$ & $1.77 \mathrm{E}-02$ & $1.77 \mathrm{E}-02$ \\
\hline Priest Rapids & Muscle & Co-60 & $11 / 11 / 88$ & $-2.94 \mathrm{E}-03$ & $1.71 \mathrm{E}-02$ & $1.71 \mathrm{E}-02$ \\
\hline Priest Rapids & Muscle & Co-60 & $11 / 11 / 88$ & $4.26 \mathrm{E}-03$ & $1.95 \mathrm{E}-02$ & $1.95 \mathrm{E}-02$ \\
\hline Priest Rapids & Muscle & Co-60 & $11 / 11 / 88$ & $1.48 \mathrm{E}-02$ & $1.54 \mathrm{E}-02$ & $1.55 \mathrm{E}-02$ \\
\hline Priest Rapids & Muscle & Cs-137 & $11 / 11 / 88$ & $6.20 \mathrm{E}-03$ & $1.82 \mathrm{E}-02$ & $1.83 \mathrm{E}-02$ \\
\hline Priest Rapids & Muscle & Cs- 137 & $11 / 11 / 88$ & $1.45 \mathrm{E}-02$ & 1.69E-02 & $1.70 \mathrm{E}-02$ \\
\hline Priest Rapids & Muscle & Cs-137 & $11 / 11 / 88$ & 2.41E-02 & $1.41 \mathrm{E}-02$ & $1.43 \mathrm{E}-02$ \\
\hline Priest Rapids & Muscle & Cs-137 & $11 / 11 / 88$ & 2.44E-02 & 2.22E-02 & 2.23E-02 \\
\hline Priest Rapids & Muscle & Cs- 137 & $11 / 11 / 88$ & 4.77E-02 & $2.11 \mathrm{E}-02$ & $2.16 \mathrm{E}-02$ \\
\hline Priest Rapids & Muscle & $\mathrm{Sr}-90$ & $11 / 11 / 88$ & 5.14E-04 & $1.44 \mathrm{E}-03$ & $1.58 \mathrm{E}-03$ \\
\hline Priest Rapids & Muscle & Sr-90 & $11 / 11 / 88$ & $1.01 \mathrm{E}-03$ & $1.74 \mathrm{E}-03$ & $1.91 \mathrm{E}-03$ \\
\hline Priest Rapids & Muscle & Sr-90 & $11 / 11 / 88$ & $1.05 \mathrm{E}-03$ & $1.68 \mathrm{E}-03$ & $1.83 \mathrm{E}-03$ \\
\hline Priest Rapids & Muscle & Sr-90 & $11 / 11 / 88$ & $1.33 \mathrm{E}-03$ & $1.48 \mathrm{E}-03$ & $1.65 \mathrm{E}-03$ \\
\hline Priest Rapids & Muscle & Sr-90 & $11 / 11 / 88$ & $1.35 \mathrm{E}-03$ & $1.69 \mathrm{E}-03$ & $1.86 \mathrm{E}-03$ \\
\hline
\end{tabular}

- indicates the analytical error exceeds the result (counting error is used when the analytical error is not reported) 
APPENDIX B

ANOVA TABLES FOR TRENDS AND LOCATION EFFECTS 


\section{APPENDIX B}

\section{ANOVA TABLES FOR TRENDS AND LOCATION EFFECTS}

This appendix contains tables of the majority of statistical analyses performed during this study. These analyses included Analysis of Variance (ANOVA) for location effects, ANOVA associated with regression analysis of tissue concentrations over time (Model I or simple regression), and for releases by year (Model II). In some analyses, log transformation may have eliminated some negative concentrations, thereby introducing a bias into the analysis. Similar analyses with nontransformed data produced similar results as reported here (i.e., if an ANOVA was not significant with transformed data, it also was not significant with transformed data). See Data Analysis section for additional discussion. 
TABLE B.1. Regression Analysis Tables for Trends in Log-Transformed Median ${ }^{137} \mathrm{Cs}$ Concentrations in Bass Muscle Sampled from F Slough

\begin{tabular}{|c|c|c|c|c|c|}
\hline \multirow{5}{*}{$\begin{array}{l}\text { Regression } \\
\text { Residual } \\
\text { Total }\end{array}$} & \multicolumn{4}{|c|}{ ANOVA Model I Regression } & \multirow{3}{*}{$\frac{\text { P-Value }}{0.010}$} \\
\hline & $\underline{\mathrm{DF}}$ & Sum of Squares & Mean Square & F-Value & \\
\hline & 1 & 0.467 & 0.467 & 12.024 & \\
\hline & 7 & 0.272 & 0.039 & & \\
\hline & 8 & 0.739 & & & \\
\hline & & ANOVA Se & der Regression & & \\
\hline & DF & Sum of Squares & Mean Square & F-Value & P-Value \\
\hline Regression & 2 & 0.544 & 0.272 & 8.375 & 0.018 \\
\hline Residual & 6 & 0.195 & 0.240 & & \\
\hline Total & 8 & 0.739 & & & \\
\hline
\end{tabular}

TABLE B.2. ANOVA for Model II Regression of Log-Transformed Median Concentrations of ${ }^{137} \mathrm{Cs}$ in Bass Muscle and Annual Releases of ${ }^{137} \mathrm{Cs}$

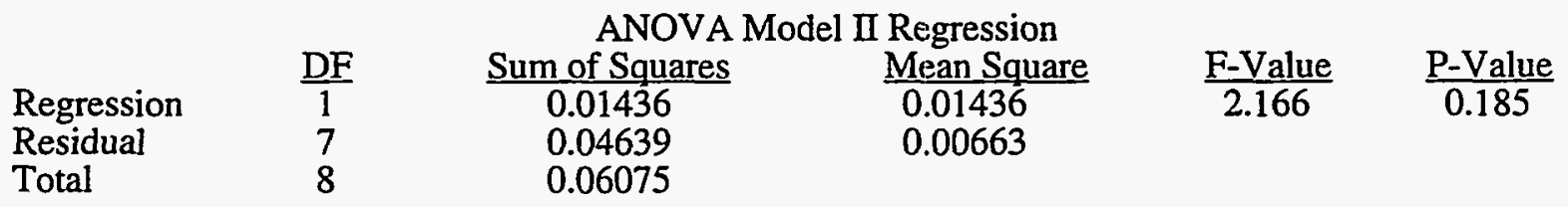

TABLE B.3. Regression Analysis Tables for Trends in Log-Transformed Median ${ }^{90} \mathrm{Sr}$ Concentrations in Bass Carcass Sampled from F Slough

\begin{tabular}{|c|c|c|c|c|c|}
\hline & $\underline{\mathrm{DF}}$ & Sum of Squares & Mean Square & F-Value & $\frac{\text { P-Value }}{0683}$ \\
\hline Regression & 1 & 0.016 & 0.016 & $\overline{0.182}$ & $\overline{0.683}$ \\
\hline Residual & 7 & 0.602 & 0.086 & & \\
\hline Total & 8 & 0.618 & & & \\
\hline
\end{tabular}

Regression

Residual

Total

\begin{tabular}{ccccc}
\multicolumn{5}{c}{ ANOVA Second-Order Regression } \\
$\frac{\text { DF }}{2}$ & $\frac{\text { Sum of Squares }}{0.544}$ & $\frac{\text { Mean Square }}{0.0851}$ & $\frac{\text { F-Value }}{1.142}$ & $\frac{\text { P-Value }}{0.380}$ \\
6 & 0.195 & 0.0746 & & \\
8 & 0.739 & & &
\end{tabular}

TABLE B.4. Regression Analysis Tables for Trends in Log-Transformed Median ${ }^{90} \mathrm{Sr}$ Concentrations in Bass Carcass Sampled from F Slough and Annual Releases of ${ }^{90} \mathrm{Sr}$

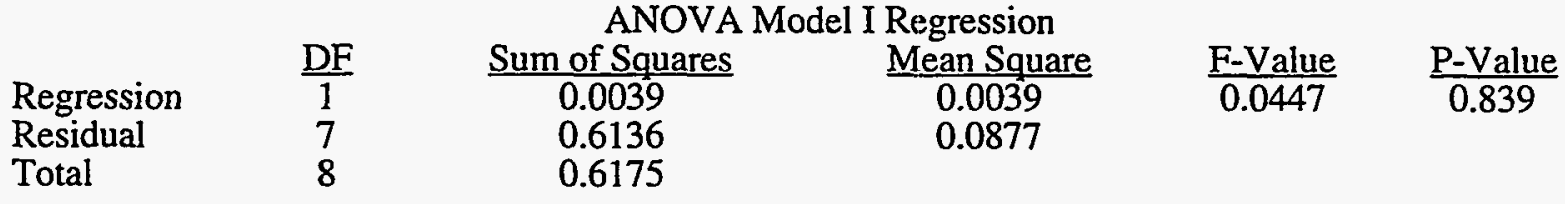


TABLE B.5. Regression Analysis Tables for Trends in Log-Transformed Median ${ }^{90} \mathrm{Sr}$ Concentrations in Whitefish Muscle Sampled from Priest Rapids and 100-N to 100-D Areas

\begin{tabular}{|c|c|c|c|c|c|}
\hline \multirow{4}{*}{$\begin{array}{l}\text { Regression } \\
\text { Residual } \\
\text { Total }\end{array}$} & \multicolumn{4}{|c|}{ ANOVA Model I Regression } & \multirow[b]{2}{*}{$\frac{\text { P-Value }}{0.024}$} \\
\hline & $\frac{\mathrm{DF}}{1}$ & $\frac{\text { Sum of Squares }}{0.1702}$ & $\frac{\text { Mean Square }}{1.025}$ & $\frac{\text { F-Value }}{8.203}$ & \\
\hline & $\cdot 7$ & 0.4473 & 0.125 & & \\
\hline & 8 & 0.6175 & & & \\
\hline \multicolumn{6}{|c|}{ ANOVA Second-Order Regression } \\
\hline & DF & Sum of Squares & Mean Square & F-Value & P-Value \\
\hline Regression & 2 & 1.053 & 0.527 & 3.732 . & 0.089 \\
\hline Residual & 6 & 0.847 & 0.141 & & \\
\hline Total & 8 & 1.900 & & & \\
\hline
\end{tabular}

TABLE B.6. ANOVA for Model II Regression of Log-Transformed Median Concentrations of ${ }^{90} \mathrm{Sr}$ in Whitefish Muscle and Annual Releases of ${ }^{90} \mathrm{Sr}$ from Priest Rapids and 100-N to 100-D Areas

\begin{tabular}{|c|c|c|c|c|c|}
\hline Regression & $\frac{\mathrm{DF}}{1}$ & Sum of Squares & $\frac{\text { Mean Square }}{08532}$ & $\frac{\text { F-Value }}{5.706}$ & $\frac{\text { P-Value }}{0.048}$ \\
\hline Residual & 7 & $\begin{array}{l}0.0502 \\
1.0468\end{array}$ & 0.1495 & & \\
\hline Total & 8 & 1.8999 & & & \\
\hline
\end{tabular}

TABLE B.7. Regression Analysis Tables for Trends in Log-Transformed Median ${ }^{137} \mathrm{Cs}$ Concentrations in Whitefish Muscle Sampled from Priest Rapids and 100-N to 100-D Areas

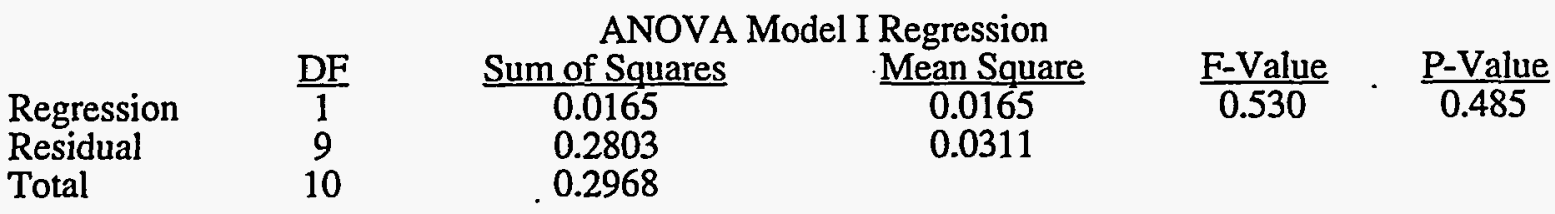

Regression Residual

Total

$\frac{\mathrm{DF}}{2}$

ANOVA Second-Order Regression

\begin{tabular}{cc} 
Sum of Squares & Mean Square \\
\hline 0.0313 & 0.0156 \\
0.2655 & 0.0332 \\
0.2968 &
\end{tabular}

$\frac{\text { F-Value }}{0.4717} \quad \frac{\text { P-Value }}{0.640}$

TABLE B.8. ANOVA for Model II Regression of Log-Transformed Median Concentrations of ${ }^{137} \mathrm{Cs}$ in Whitefish Muscle and Annual Releases of ${ }^{137} \mathrm{Cs}$ from Priest Rapids and $100-\mathrm{N}$ to 100 D Areas

\begin{tabular}{lccccc} 
& \multicolumn{4}{c}{ ANOVA Model I Regression } \\
Regression & DF & Sum of Squares & $\frac{\text { Mean Square }}{0.0606}$ & $\frac{\text { F-Value }}{2.3089}$ & $\frac{1}{\text { P-Value }}$ \\
Residual & 9 & 0.163 & & & \\
Total & 10 & 0.2362 & 0.0264 & &
\end{tabular}


TABLE B.9. Regression Analyses for Trends in Log-Transformed Median ${ }^{90} \mathrm{Sr}$ Concentrations in Whitefish Carcass Collected from Priest Rapids and 100-N to 100-D Areas

\begin{tabular}{|c|c|c|c|c|c|}
\hline \multirow{5}{*}{$\begin{array}{l}\text { Regression } \\
\text { Residual } \\
\text { Total }\end{array}$} & \multicolumn{4}{|c|}{ ANOVA Model I Regression } & \multirow{3}{*}{$\frac{\text { P-Value }}{0.007}$} \\
\hline & $\underline{\mathrm{DF}}$ & Sum of Squares & Mean Square & \multirow{4}{*}{$\frac{\text { F-Value }}{12.270}$} & \\
\hline & 1 & 0.335 & 0.335 & & \\
\hline & 9 & 0.246 & 0.027 & & \\
\hline & 10 & 0.580 & & & \\
\hline & & ANOVA Se & rder Regression & & \\
\hline & $\underline{\mathrm{DF}}$ & Sum of Squares & Mean Square & $\frac{\text { F-Value }}{12022}$ & $\frac{\text { P-Value }}{0022}$ \\
\hline Regression & 2 & 0.449 & 0.224 & 13.623 & 0.003 \\
\hline Residual & 8 & 0.132 & 0.016 & & \\
\hline Total & 10 & 0.580 & & & \\
\hline
\end{tabular}

TABLE B.10. ANOVA for Model II Regression of Log-Transformed Median Concentrations of ${ }^{90} \mathrm{Sr}$ in Whitefish Carcass and Annual Releases of ${ }^{90} \mathrm{Sr}$

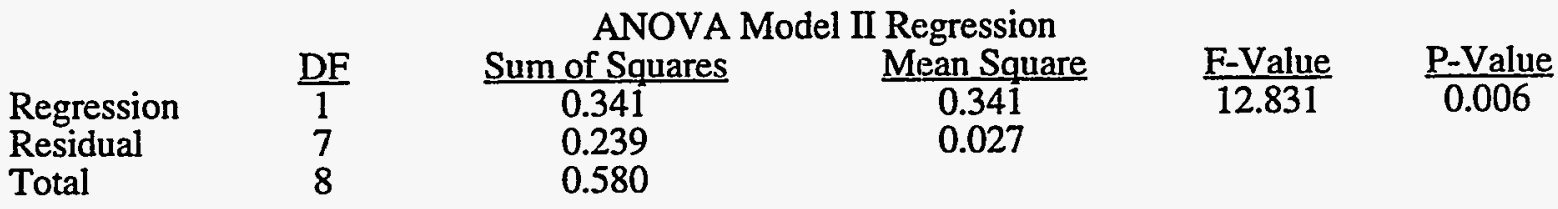

TABLE B.11. ANOVA of Log-transformed ${ }^{137} \mathrm{Cs}$ Concentrations in Bass Muscle Sampled from F Slough and Sunnyside, 1990 Through 1992

\begin{tabular}{|c|c|c|c|c|c|}
\hline -Oct & $\frac{\mathrm{DF}}{1}$ & $\frac{\text { Sum of Squares }}{0.110}$ & $\frac{\text { Mean Square }}{0.110}$ & $\frac{\text { F-Value }}{0.670}$ & $\frac{\text { P-Value }}{0.4233}$ \\
\hline Residual & 19 & 3.119 & 0.164 & & \\
\hline
\end{tabular}

TABLE B.12. ANOVA of Log-Transformed ${ }^{90} \mathrm{Sr}$ Concentrations in Bass Carcass Sampled from F Slough and Sunnyside, 1990 Through 1992

Location

$\begin{array}{cc}\frac{\text { DF }}{1} & \frac{\text { Sum of Squares }}{2.331} \\ 27 & 2.030\end{array}$

\begin{tabular}{lll} 
Mean Square & F-Value \\
\hline 2.331 & P-Value \\
0.075 & & $\frac{0.0001}{1.002}$
\end{tabular}

TABLE B.13. Scheffé's Comparisons of Log-Transformed Means of ${ }^{90} \mathrm{Sr}$ in Bass Carcass Collected from F Slough and Sunnyside, 1990 Through 1992

\begin{tabular}{|c|c|c|c|c|c|}
\hline Location & $\underline{N}$ & $\begin{array}{l}\text { Mean } \\
\mathrm{pCi} / \mathrm{g}\end{array}$ & $\underline{\log \text { Mean }}$ & $\begin{array}{c}\text { Mean } \\
\text { Difference }\end{array}$ & $\begin{array}{l}\text { Scheffé's } \\
\text { P-Value }\end{array}$ \\
\hline F Slough & $\overline{10}$ & 0.025 & -1.639 & & \\
\hline Sunnyside & 19 & 0.007 & -2.235 & 0.596 & \\
\hline
\end{tabular}


TABLE B.14. ANOVA of Log-Transformed ${ }^{90} \mathrm{Sr}$ Concentrations in Bass Carcass Sampled from F Slough, 1983 Through 1992

Year

Residual

$\begin{array}{cc}\frac{\text { DF }}{8} & \text { Sum of Squares } \\ 36 & 4.046 \\ & 5.532\end{array}$
Mean Square
0.506
0.154

$\frac{\text { F-Value }}{3.291} \quad \frac{\text { P-Value }}{0.0064}$

TABLE B.15. ANOVA of Log-Transformed ${ }^{137}$ Cs Concentrations in Carp Muscle by Location, 1990 Through 1992

Location

Residual

$\begin{array}{cc}\frac{\mathrm{DF}}{2} & \frac{\text { Sum of Squares }}{1.243} \\ 30 & 5.386\end{array}$
Mean Square F-Value 3.462
0.622
0.180

\section{P-Value}

TABLE B.16. ANOVA of Log-Transformed ${ }^{137}$ Cs Concentrations in Carp Muscle by Year and Location, 1990 Through 1992

DF Sum of Squares $\quad$ Mean Square $\quad \underline{\text { F-Value }} \quad \underline{\text { P-Value }}$

\begin{tabular}{lccccc}
\hline \multicolumn{7}{c}{ Vantage } \\
Rear & 1 & 0.002 & 0.002 & 0.007 & 0.9347 \\
Residual & 11 & 3.407 & 0.310 & & \\
\hline Year & 2 & 0.102 & $100-\mathrm{N}$ to $100-\mathrm{D}$ Area & \\
Residual & 8 & 1.440 & 0.051 & 0.282 & 0.7612 \\
& & & 0.180 & & \\
\hline Year & 1 & 0.039 & 300 Area & & 0.4317 \\
Residual & 7 & 0.396 & 0.039 & 0.696 &
\end{tabular}

TABLE B.17. ANOVA of Log-transformed ${ }^{90} \mathrm{Sr}$ Concentrations in Carp Carcass by Location, 1990 Through 1992

$\begin{array}{lccccc} & \text { DF } & \text { Sum of Squares } & \text { Mean Square } & \text { F-Value } & \text { P-Value } \\ \text { Location } & 2 & 1.289 & 0.644 & 3.734 & 0.0352 \\ \text { Residual } & 31 & 5.350 & 0.173 & \end{array}$


TABLE B.18. ANOVA of Log-Transformed ${ }^{90} \mathrm{Sr}$ Concentrations in Carp Carcass by Year and Location, 1990 Through 1992

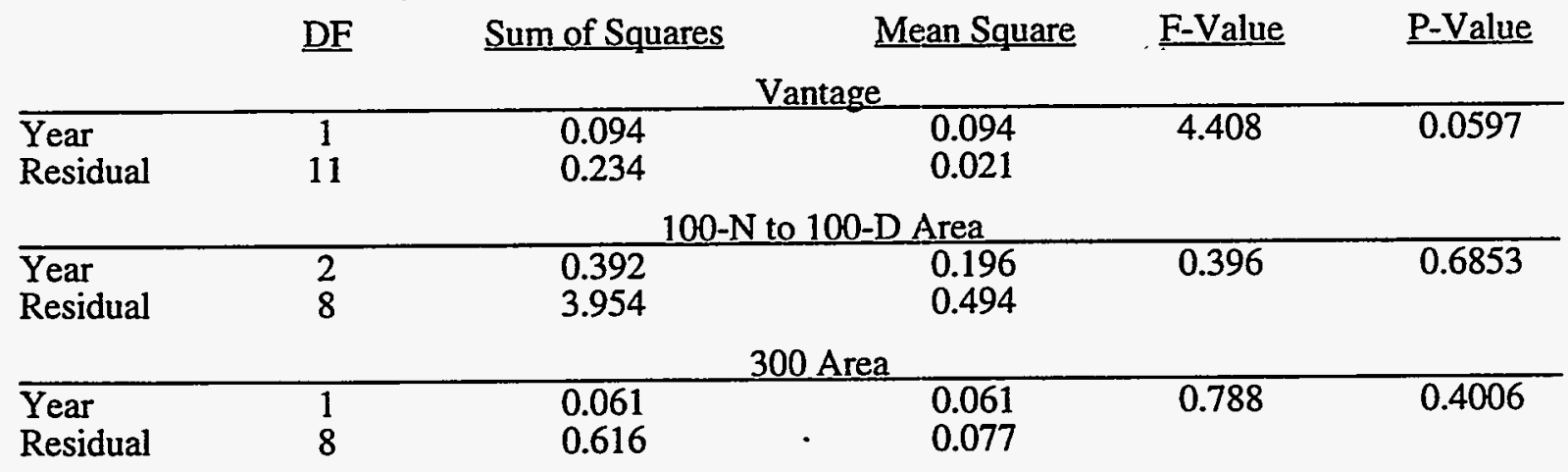

TABLE B.19. ANOVA of Log-Transformed ${ }^{90} \mathrm{Sr}$ Concentrations in Whitefish Muscle by Location, 1988 Through 1992

Location

$\begin{array}{cc}\frac{D F}{3} & \text { Sum of Squares } \\ 73 & 7.980 \\ 27.702\end{array}$
Mean Square $\quad$ F-Value $\quad \underline{\text { P-Value }}$ $2.660 \quad 7.010 \quad 0.0003$

Residual

TABLE B.20. ANOVA of Log-Transformed ${ }^{90} \mathrm{Sr}$ Concentrations in Whitefish Muscle by Year and Location, 1982 Through 1992

DF Sum of Squares $\quad \underline{\text { Mean Square }} \quad \underline{\text { F-Value }} \quad \underline{\text { P-Value }}$

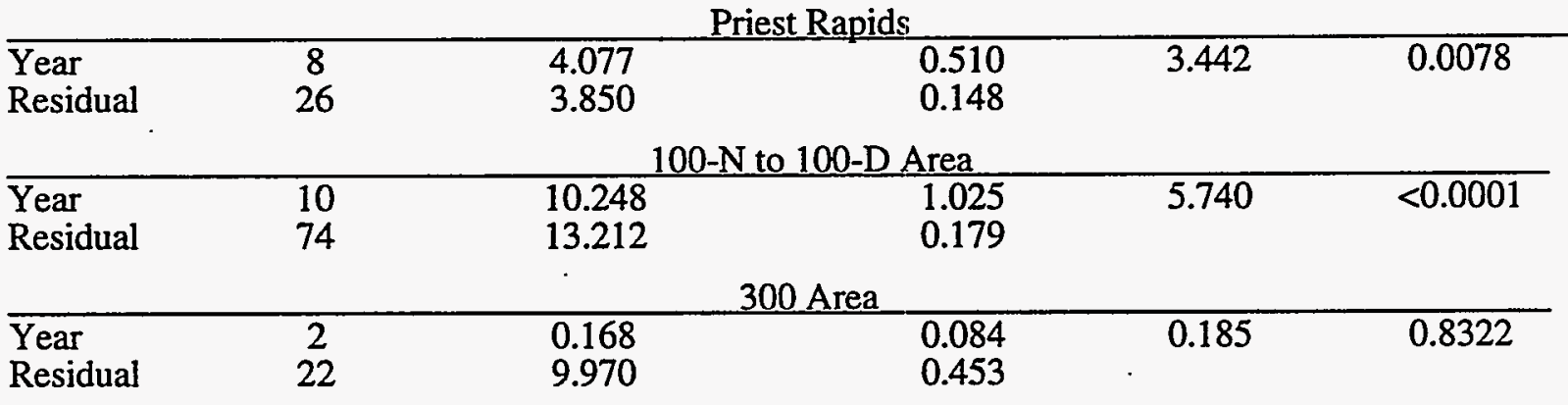

TABLE B.21 ANOVA of Log-Transformed ${ }^{137} \mathrm{Cs}$ Concentrations in Whitefish Muscle by Location, 1988 Through 1992

Location

Residual

$\begin{array}{cc}\frac{D F}{3} & \frac{\text { Sum of Squares }}{68} \\ 68 & 9.581\end{array}$

9.581

\author{
$\frac{\text { Mean Square }}{0.362} \quad \frac{\text { F-Value }}{2.571}$ \\ 0.362 \\ 0.141
}

\section{$\frac{\text { P-Value }}{0.061}$}


TABLE B.22. ANOVA of Log-Transformed ${ }^{137} \mathrm{Cs}$ Concentrations in Whitefish Muscle by Year and Location, 1982 Through 1992

\begin{tabular}{|c|c|c|c|c|c|}
\hline & $\mathrm{DF}$ & Sum of Squares & Mean Square & F-Value & $\underline{\mathrm{P}-\text { Value }}$ \\
\hline & & Priest $\mathrm{R}$ & 982-1990) & & \\
\hline $\begin{array}{l}\text { Year } \\
\text { Residual }\end{array}$ & $\begin{array}{c}8 \\
25\end{array}$ & $\begin{array}{l}1.506 \\
5.239\end{array}$ & $\begin{array}{l}0.188 \\
0.210\end{array}$ & 0.899 & 0.533 \\
\hline $\begin{array}{l}\text { Year } \\
\text { Residual }\end{array}$ & $\begin{array}{l}10 \\
84\end{array}$ & $\begin{array}{c}100-\mathrm{N} \text { to } 10 \\
1.177 \\
10.981\end{array}$ & 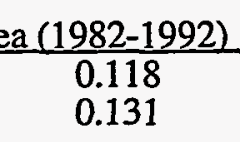 & 0.900 & 0.537 \\
\hline & & 300 & $90-1992)$ & & \\
\hline $\begin{array}{l}\text { Year } \\
\text { Residual }\end{array}$ & $\begin{array}{c}2 \\
11\end{array}$ & $\begin{array}{l}0.381 \\
1.645\end{array}$ & $\begin{array}{l}0.190 \\
0.150\end{array}$ & 1.273 & 0.318 \\
\hline
\end{tabular}

TABLE B.23. ANOVA of Log-Transformed ${ }^{90} \mathrm{Sr}$ Concentrations in Whitefish Carcass by Location, 1988 Through 1992

Location

Residual

$\begin{array}{cc}\frac{\text { DF }}{3} & \frac{\text { Sum of Squares }}{1.186} \\ 68 & 3.199\end{array}$
Mean Square 0.395 0.053

\section{$\frac{\text { F-Value }}{7.416}$ \\ 7.416}

$\underline{\text { P-Value }}$

3.199

0.0003

TABLE B.24. ANOVA of Log-Transformed ${ }^{90} \mathrm{Sr}$ Concentrations in Whitefish Carcass by Year and Location, 1982 Through 1992
$\underline{\mathrm{DF}}$
Sum of Squares
Mean Square F-Value
$\underline{\text { P-Value }}$

\begin{tabular}{lc}
\hline Year & 8 \\
Residual & 31
\end{tabular}

Priest Rapids (1982-90)

$\begin{array}{rrrrr}8 & 1.103 & 0.138 & 4.202 & 0.0017 \\ 31 & 1.017 & 0.033 & & \end{array}$

100-N to 100-D Area (1982-91)

\begin{tabular}{lccccc}
\hline Year & 9 & 4.465 & 0.447 & 11.825 & $<0.0001$ \\
Residual & 77 & 3.210 & 0.038 & &
\end{tabular}

\begin{tabular}{lccccc}
\multicolumn{5}{c}{300 Area (1990 and 1992) } \\
\hline Year & 2 & 0.108 & 0.054 & 1.196 & 0.3314 \\
Residual & 14 & 0.634 & 0.045 & &
\end{tabular}


TABLE B.25. Yearly Comparison of Statistically Significant Differences by Fisher's PLSD Test of ${ }^{90} \mathrm{Sr}$ in Whitefish Carcass (Log-Transformed Mean)Collected at Priest Rapids and the 100-N to $100-\mathrm{D}$ Areas

Priest Rapids

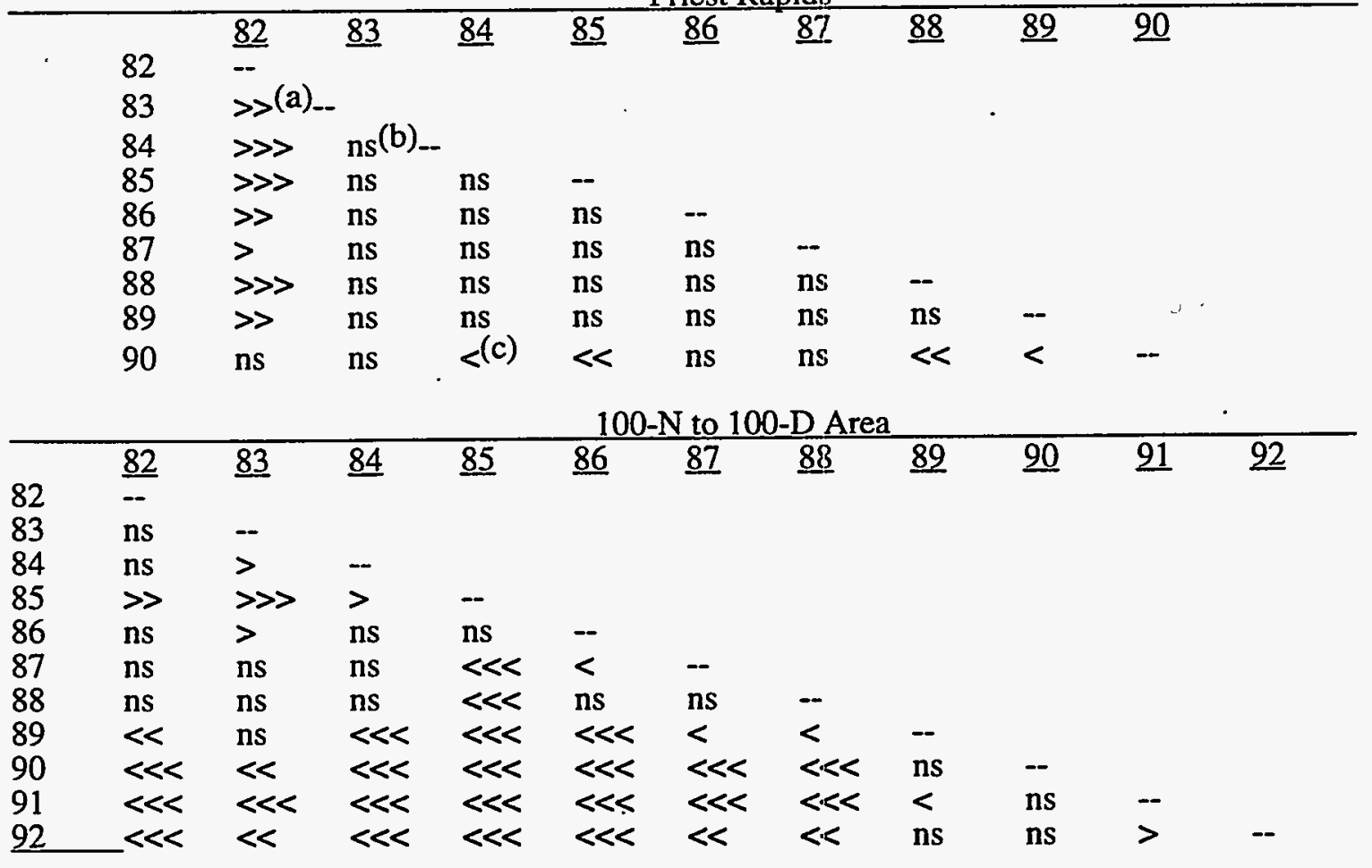

(a) Read from top down, i.e., 1982 (column heading) was significantly less than 1983 (row heading) at $P \leq 0.01$.

(b) Not Significant =ns; symbols indicate: $<$ or $>$ at $\mathrm{P} \leq 0.05, \ll$ or $>>$ at $\mathrm{P} \leq 0.01$, and $\ll$ or $>>$ at $\mathrm{P} \leq 0.001$.

(c) Read from top down, i.e., 1984 (column heading) was significantly greater than 1990 (row heading) at $\mathrm{P} \leq 0.05$. 


\section{DISTRIBUTION}

No. of

Copies

\section{OFFSITE}

2 Office of Scientific and Technical Information

2 Golder Associates 4104 148th Avenue N.E. Redmond, WA 98052 Attention: L. Swenson Attention: W. Wright

S. F. Cross

Washington Department of Ecology

Mail Stop PV-11

Olympia, WA 98504-8711

Environmental Restoration/

Waste Mangement

Yakama Indian Nation

P.O. Box 151

Toppenish, WA 98948 ,

Attention: R. Jim

3 Confederated Tribes of the Umatilla Indian Reservation P.O. Box 638

Pendleton, OR 97801

Attention: J. R. Wilkinson

Attention: A. Childs

Attention: R. George

Nez Perce Tribe

P.O. Box 365

Lapwai, ID 83540-0365

Attention: D. Powaukee

D. Teel

Washington State Department of Ecology

Nuclear Waste Program

P.O. Box 1386

Richland, WA 99352
No. of

Copies

\author{
J. Erickson \\ Washington State Department \\ of Health \\ Division of Radiation \\ Protection \\ Airdustrial Center \\ Building 5, M.S. C-13 \\ Olympia, WA 98503
}

\section{ONSITE}

8 DOE Richland Operations

Office

R. F. Brich

E. D. Goller

J. B. Hall (5)

D. C. Ward

2 U.S. Environmental Protection

Agency

L. E. Gadbois

P. S. Innes

9 Westinghouse Hanford Company

L. P. Diediker

J. J. Dorian

G. E. Fitzgibbon

E. M. Greager

A. R. Johnson

C. J: Perkins

J. W. Schmidt

S. G. Weiss

Public Reading Room

56 Pacific Northwest Laboratory

C. S. Abernethy

E. J. Antonio

D. J. Bates

Distr. 1 
PNL-9960

No. of

Copies

M. L. Blanton

C. A. Brandt

R. W. Bryce

L. L. Cadwell

A. T. Cooper

C. E. Cushing

D. D. Dauble

R. L. Dirkes

S. L. Friant

D. E. Geist

J. A. Hall

R. W. Hanf, Jr.

R. E. Jaquish

R. E. Lundgren

E. W. Lusty

D. A. Neitzel

G. W. Patton

T. M. Poston (20)

K. M. Probasco

J. K. Soldat

M. E. Thiede

B. L. Tiller

H. E. Westerdahl (3)

Publishing Coordination

SESP Historical Files/

R. L. Dirkes (2)

Technical Report Files (5)
No. of

Copies

Routing

R. M. Ecker

M. J. Graham

P. M. Irving

C. S. Sloane

P. C. Hays - last

Distr. 2 